\title{
AVALIAÇÃO DOS EFEITOS CITOTÓXICOS E ANTIPROLIFERATIVOS DA SECREÇÃO CUTÂNEA E DE PEPTÍDEOS DO ANURO
}

Physalaemus nattereri (STEINDACHNER, 1863)

\section{ANDRÉA CRUZ E CARVALHO}

Orientadora: Profa. Dra. Mariana S. Castro

Tese apresentada ao Instituto de Ciências Biologicas da Universidade de Brasilia, como parte dos requisitos para obtenção do título de Doutor em Biologia Animal. 


\section{Tese de Doutorado}

\section{ANDREA CRUZ E CARVALHO}

Título:

Avaliação dos efeitos citotóxicos e antiproliferativos da secreção cutânea e de peptídeos do anuro Physalaemus nattereri (Steindachner, 1863)

\section{Comissão Examinadora:}

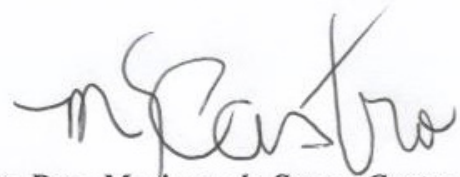

Profa. Dra. Mariana de Souza Castro

Presidente / Orientador

$U n B$

\section{Alive Lima de ovivin}

Profa. Dra. Aline Lima de Oliveira

Membro Titular Interno não Vinculado ao Programa

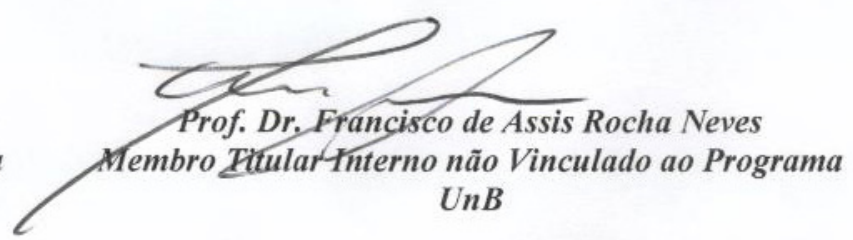

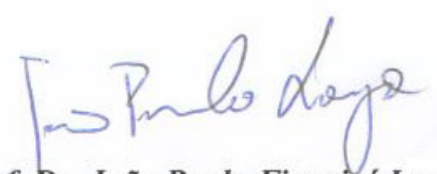

Prof. Dr. João Paulo Figueiró Longo Membro Tifular Interno Vinculado ao Programa $U C B$

\section{Mavisa Rangel}

Profa. Dra. Marisa Rangel

Membro Titular Externo não Vinculado ao Programa Instituto Butantan

Profa. Dra. Carolina Madeira Lucci

Membro Suplente

Interno Vinculado ao Programa

$\mathrm{UnB}$

Brasília, 30 de março de 2015. 
Dedico esta Tese de Doutorado A todos aqueles que se fizeram presentes: Familiares, Amigos, e Amores... em que sempre me inspirei e foram motivo de Afetos, Alegrias, e Ânimo, Para sempre lutar... 
O rio atinge seus objetivos porque aprendeu a contornar obstáculos. ( $\mathfrak{L a c}_{\text {ase }} \mathfrak{J}_{\text {se }}$

"Q vida é uma sucessão de desequilibrios equilibrados e de equilibrios desequilibrados. São mais felizes aqueles que se equilibram nos desequilibrios. Jropeçam, mas não caem, magoam-se, mas não choram, bakem-lhes, mas não thes dói. Sostam do que é simples, desvalorizam o negativo, facilitam o complicado, sorriem porque nada é razão para estar kriske. Basta estar vivo

$$
\begin{aligned}
& \text { para ser feliz" } \\
& \text { (Oaria Oítar Campos) }
\end{aligned}
$$

"Irabaltho é amor feito visível. Se não podes trabalhar com amor, mas somente com desgosto, è melhor deixar a trabatho, sentar no portão do templo e pedir esmola àqueles que trabalham com alegria" (Tahil Gibran) 


\section{AGRADECIMENTOS}

À Profa. Dra. Mariana S. Castro, pela orientação do presente trabalho. Se tive coragem de chegar até aqui, foi pela sua confiança.

Ao Prof. Dr. Osmindo Rodrigues Pires Jr. pela amizade, pelas sugestóes, pelas coletas do veneno bruto que foi material de estudo do presente trabalho.

Ao Profa. Dra. Graziella Anselmo Joanitti, por toda a ajuda durante os ensaios de Citometría de Fluxo. Querida Grazi, sem a sua ajuda e colaboração nada disso teria sido possivel. Muito obrigada !!!

Ao Laboratório de Morfologia e Morfogênese da Universidade de Brasitia, pela colaboração na reatização dos ensaios antitumorais.

Ao Dr. Oleg Vladimirovich Krasilnikov (in memoriam) que me acothew no Laboratório de Biofisica de Membranas na UFPE, quando ew nem imaginava o que era Ciência, faltava ainda um semestre para iniciar o mew curso de Ciencias Biológicas e já comecei a Iniciação Cientifica sob sua supervisão, e $\sigma$ senhor nã $\sigma$ imagina $\sigma$ quão vatioso foram esses cinco anos para mim.

Ao mew amigo, companheiro e confidente, César Augusto Prías-Marquez (Vulgo Garfield) sempre e em todos os momentos um ombro Amigo. Obrigada por todas as incontáve is madrugadas adentro de trabalho ardwo, de inumeros sorrisos, de cansaço, de ricas discussóes e aprendizado, Obrigada!!! Mesmo sem voce saber, durante vários meses, foi meu incentivo diario para não deixar a "peteca cair". E não me esquecerei de você amigo, Prías sem sua ajuda nada disso sería possivel.

Ao mew amigo incondicional Harry Morales Duque, pela companhia inseparável em todos os momentos de "desespero" e sempre com sew humor positivo. Obrigada mew amigo. Você mora no mew coração e para sempre!!!

As amigas Diana Jimena Monsalve, e Ana Cevelyn Sempre e por todo tempo, pessoas admiráveis que jamais houvesse conhecido antes.

As amigas: Alininha, Jéssica Arruda, e Rosa Dueñas jamais irei esquecerme de vocês, sempre presentes com um astral maravithoso.

Aos maravithosos amigos que conquistei no Laboratório de Bioquimica e Química de Proteinas, Alininha, Ana Carolinne, Arthur, Anne, César, Diana, Diego, Elaine, Elena Triana, Jaques, e Micaella, agradeço a todos vocês por estarem sempre disponiveis pra auxitiarem no desenvolvimento desse trabalho. Pelo companheirismo, pelos momentos de descontração e por alegrar os dias em que ew estava tão exausta e mesmo assim, sorrir diante das nossas conversas. A todos vocês. Muito Obrigada! 
Ao Nuno Domingues, pelo apoio operacional, e que se dispós tantas vezes a ajudar mesmo estando no horário do sew almoço, e às vezes, mesmo depois do horário do expediente do Laboratório.

Aos amigos que também conquistei e levo na minha memória aqueles que fazem parte do Laboratório de Toxinologia: Ana Carolina Martins, Beatriz Elena, Caroline Barbosa, Carlos Santana, Fagner Neves, Tânia Barth, Thalita Camargos, Natiela Beatriz, Solange Rego, Lilibete Pereira, Jimmy Guerreiro, e Washington oliveira pela convivência diária, ensinamentos, conversas e momentos de grande descontração.

À amizade mais sincera que conheci. Mariana Meirelles (Mari) como não lembrar de voce?! Uma das poucas pessoas que me doava sew tempo, sew astral, suas experiências, seus conselhos, sew apoio no periodo mais difícil... amiga confidente que ew amo.

À amiga Raquel Aline, a amizade que se iniciou recentemente, mas com tanto carinho e incentivo, obrigada por todo apoio e palavras de confiança e otimismo sempre presente. Já faz parte de minha vida... muito obrigada!

Ao mew amigo Adriano Martins, amigo de infância. E como não lembrar de você?! Sempre disposto a ajudar, e me ouvir, nas horas dificeis em que eu mais precisei sempre ati.

À amiga de Graduação, Karol Leitão que além de minha confidente por mais de 10 anos, tive a oportunidade de ver $\sigma$ exemplo de honestidade, e lealdade que você é, e sempre será a melhor amiga, aquela que me ouve nos momentos de alegria e naqueles que mais precisei: os de tristeza também.

Ao mew Querido Gílberto Mansur, grande ouvidor, companheiro e responsável por me distrair quando eu mais precisava... A cada jantar, me falava como um grande Jornalista que é, das suas experiências de vída, e me mostrava que aquelas adversidades que eu tinha, era tudo passageiro, e que ew iria levar um aprendizado de cada uma delas.

As secretarias da Pós Graduação em Biologia Animal, Ana Paula Cabral e Daniele Cristiane de Lara Brito, que sempre que precisei, em qualquer momento, estavam dispostas a ajudar, e imediatamente.

Aos Amigos e Amigas, que conquistei pela vida e que se tornaram uma boa surpresa ao longo desse trabatho... O que seria de mim, sem a companhia de vocês? Serena Kierzkowski, Ingrid Freire, Cristiane Maldonado, Juliana Lins, Kátia Leão, Lourdes Dias, Emanoel Barros, Márcio Justino, Everton Rosa, Rodrigo André, Rodolfo Batista, Vicente Mainenti.

Ao Programa de Pós Graduação em Biologia Animal, A Universidade de Brasitia, e ao Conselho Nacional de Desenvolvimento Científico e Tecnológico (CNPq) peto apoio financeiro. 


\section{APOIO FINANCEIRO}

A tese de doutorado intitulada "Avaliação dos efeitos citotóxicos e antiproliferativos da secreção cutânea e de peptídeos bioativos do anuro Physalaemus nattereri (steindachner, 1863)" desenvolvida por Andréa Cruz e Carvalho sob a orientação da profa. Dra. Mariana S. Castro teve o apoio financeiro do CNPq (processos no. 563972/2010-6, Edital MCT/CNPQ/FNDCT/FAPS/MEC/CAPES/PRÓ-CENTROOESTE no 31/2010, n’. 302925/2012-0, Produtividade em Pesquisa - PQ - 2012 e n̊. 407801-2013, Rede Centro-Oeste De Pós-Graduação, Pesquisa E Inovação REDE PRÓ-CENTRO-OESTE), da FAPDF (processo no. 193. 000.461/2011, Edital MCT/CNPQ/FNDCT/FAPS/MEC/CAPES/PRÓ-CENTRO-OESTE $\mathrm{n}^{\circ}$ 31/2010), do CNPq por meio da concessão de bolsa de estudos (nível doutorado), da FINEP (CT-INFRA) E DA FUB-UNB. 


\section{ÍNDICE GERAL}

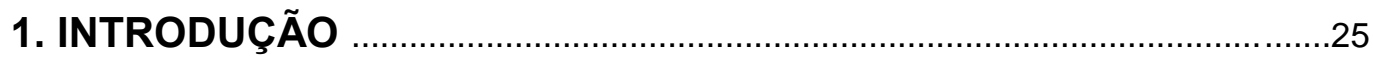

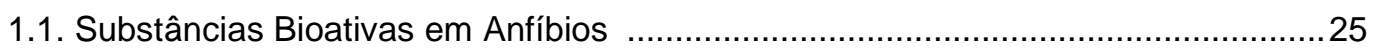

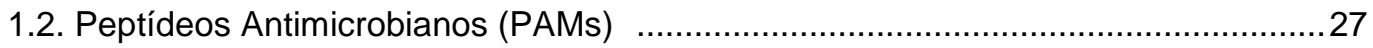

1.3. Antibióticos Convencionais e Sua Utilização na Terapia ......................................30

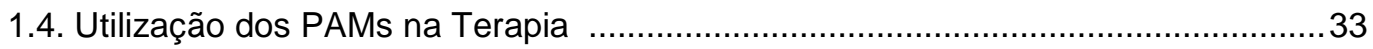

1.5. Resistência Bacteriana e Bactérias Patogênicas ................................................38

1.5.1. Breve Histórico da Resistência Bacteriana ................................................... 42

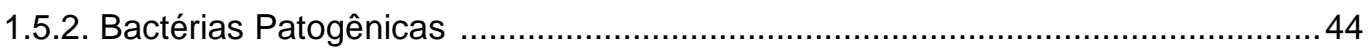

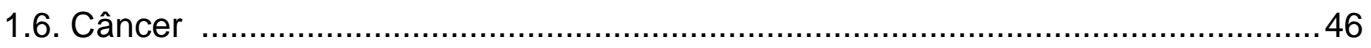

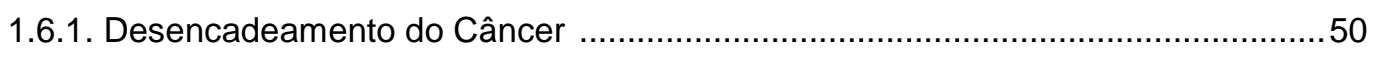

1.6.2. Desenvolvimento dos Estágios do Câncer ...................................................... 53

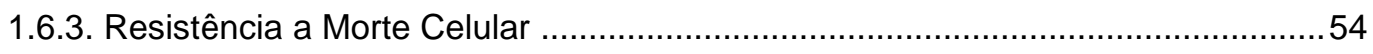

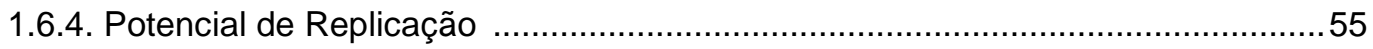

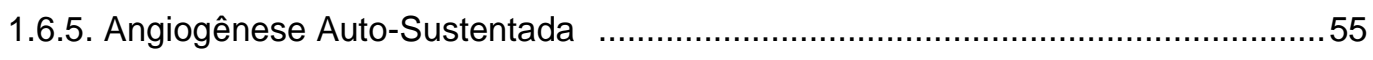

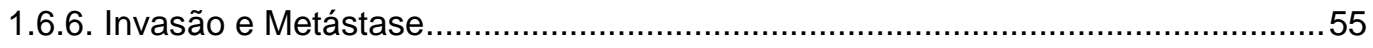

1.6.7. Fatores Facilitadores e Características dos Tumores …....................................56

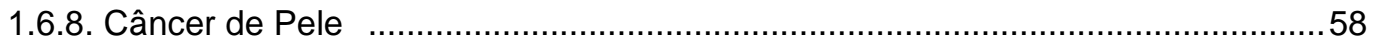

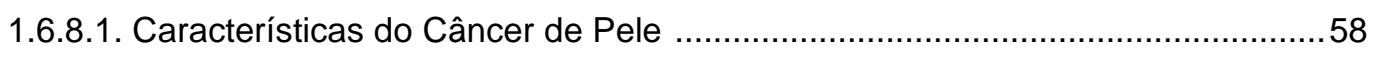

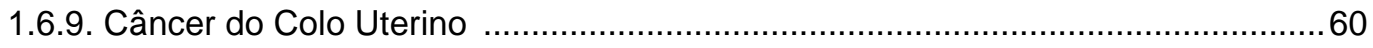

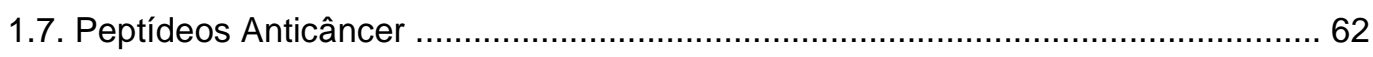

1.7.1. Mecanismos de Ação dos Peptídeos Anticâncer ..............................................63

1.7.2. A Seletividade dos Peptideos Anticâncer Pelas Células Tumorais .....................66

1.7.2.1. Estratégias para aumentar a eficiência dos peptídeos anticâncer.....................67

1.8. Physalaemus nattereri (STEINDACHNER, 1863) .............................................69

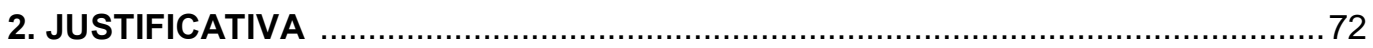

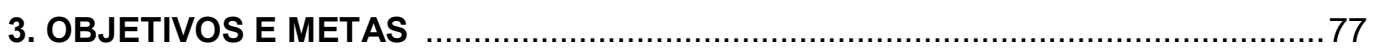

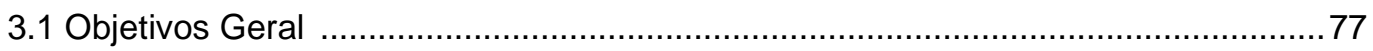

3.2 Metas Estabelecidas no Presente Estudo …...........................................................77 
4.1. Ensaios de Citotoxicidade Sobre Linhagens Celulares Tumorais ..... 80

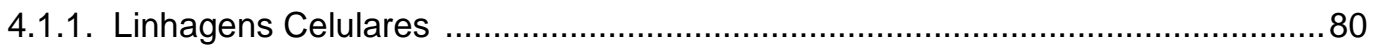

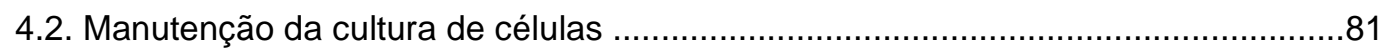

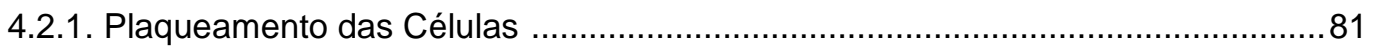

4.3. Tratamento das Células Tumorais com a Secreção Bruta e os Peptideos Isolados

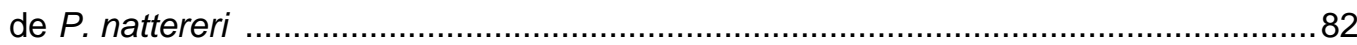

4.4. Avaliação da Viabilidade Celular Empregando-se o Método MTT 83

4.5. Investigação do Mecanismo de Ação da Secreção Cutânea Bruta de $P$. nattereri

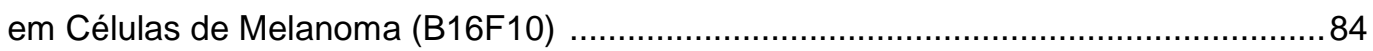

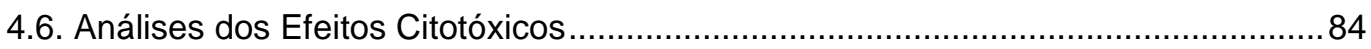

4.6.1. Análise dos Efeitos Sobre a Morfologia Celular ................................................... 84

4.6.2. Ensaios Empregando a Técnica de Citometria de Fluxo …................................... 85

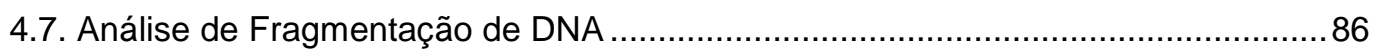

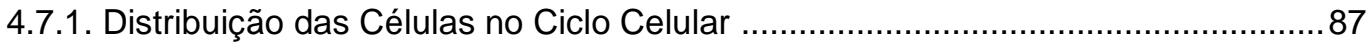

4.7.1.1. Análise dos Efeitos do Veneno Bruto P. nattereri no Ciclo Celular....................87

4.7.2. Apoptose Versus Necrose Detectada com Anexina-V-FITC e lodeto de Propídeo

(PI) 88

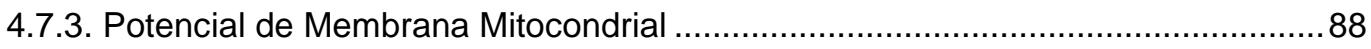

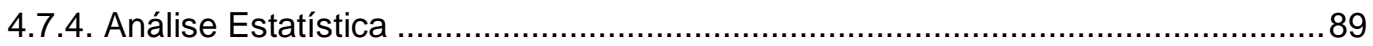

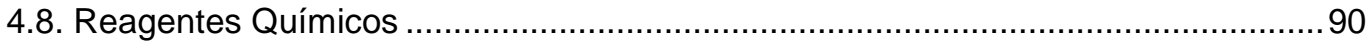

4.9. Coleta dos Animais e Obtenção da Secreção Cutânea de $P$. nattereri ...................90

4.9.1. Fracionamento Cromatográfico da Secreção Cutânea de $P$. nattereri ...................90

4.9.2. Purificação dos Peptídeos Bioativos Presentes na Secreção de P. nattereri.......91

4.9.3. Análise por Espectrometria de Massa do tipo MALDI-TOF ................................91

4.9.4. Ensaios Hemolíticos .................................................................................. 92

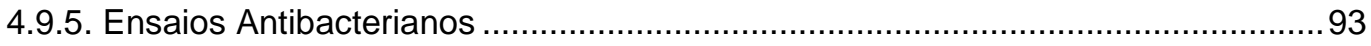

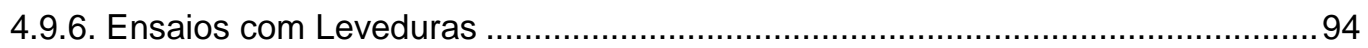

4.10. Tratamento das Células Tumorais com os Peptídeos Isolados de P. nattereri .....94

4.11. Avaliação da Viabilidade Celular Empregando -se o Método MTT . 96 
5.1. Avaliação Prévia dos Efeitos Citotóxicos e Antiproliferativos da Secreção Cutânea Bruta de P. nattereri Sobre Células Tumorais das Linhagens B16F10 e HeLa 99

5.2. Efeitos da Secreção Cutânea Bruta de P. nattereri Sobre a Morfologia Celular......102 5.3. Efeitos da Secreção Cutânea Bruta de P. nattereri Sobre a Granulosidade e Tamanho das Células de Melanoma Murino (B16F10) .103

5.4. Efeitos da Secreção Cutânea Bruta de P. nattereri Sobre a Membrana Plasmática das Células de Melanoma Murino (B16F10)

5.5. Efeitos da Secreção Cutânea Bruta de P. nattereri Sobre o Potencial de Membrana Mitocondrial das Células de Melanoma Murino (B16F10) 105 5.6. Efeitos da Secreção Cutânea Bruta de P. nattereri Sobre o Ciclo Celular das Células de Melanoma Murino (B16F10) 107

5.7. Fracionamento Cromatográfico da Secreção Cutânea Bruta de P. nattereri ........108 5.8. Avaliação Preliminar das Atividades Antibacteriana, Antifúngica, Hemolítica e Antitumoral 108

5.9. Análise por Espectrometria de Massas Tipo MALDI-TOF das Frações Cromatográficas de $P$. nattereri 114

5.10. Purificação dos Peptídeos Antimicrobianos e Anticâncer Presentes na Secreção Cutânea de $P$. nattereri 116

5.11. Identificação dos Peptídeos Antimicrobianos e Anticâncer Presentes na Secreção Cutânea de $P$. nattereri 121

5.12. Avaliação dos Efeitos Citotóxicos e Antiproliferativos das nattererinas Sobre Células Tumorais da Linhagem HeLa 122

5.12.1. Efeitos Sobre a Viabilidade Celular ...........................................................122

5.12.2. Efeitos Sobre a Morfologia Celular 124

5.13. Determinação da Concentração Inibitória Mínima (Mics) Para os Peptídeos Isolados Apartir da Secreção Bruta de P. nattereri 126

6. DISCUSSÃO 127

7. CONCLUSÃO 143 
8. CONSIDERAÇÕES FINAIS

9. REFERÊNCIAS BIBLIOGRÁFICAS 


\section{LISTA DE TABELAS}

Tabela 1. Principais membros dos PAMs de mamíferos e suas famílias.

Tabela 2. Classificação dos antimicrobianos em função de diversas variáveis.

Tabela 3. Agentes infecciosos mais comumente encontratos em humanos e seus locais de isolamento. .47

Tabela. 4. Avaliação da atividade inibitória sobre a proliferação das bactérias patogênicas $S$. aureus e E. cloacae das frações cromatográficas obtidas com o fracionamento da secreção cutânea de Physalaemus nattereri por RP-HPLC em coluna $\mathrm{C}_{18}$ 110

Tabela. 5. Avaliação da atividade inibitória sobre a proliferação do fungo patogênico Cryptococcus neoformans das frações cromatográficas obtidas com o fracionamento da secreção cutânea de Physalaemus nattereri por RP-HPLC em coluna $\mathrm{C}_{18}$

Tabela. 6. Avaliação da atividade inibitória sobre a proliferação do fungo patogênico Candida albicans das frações cromatográficas obtidas com o fracionamento da secreção cutânea de Physalaemus nattereri por RP-HPLC em coluna $\mathrm{C}_{18}$

Tabela. 7. Avaliação da atividade inibitória sobre a proliferação de células de melanoma murino (B16F10) das frações cromatográficas obtidas com o fracionamento da secreção cutânea de Physalaemus nattereri por RP-HPLC em coluna $\mathrm{C}_{18}$

Tabela. 8. Comparação da atividade citotóxica sobre as linhagens celulares HeLa (câncer de colo uterino) e NIH-3T3 (fibroblasto normal) das nattererinas 1, 2 e 3.

Tabela 9. Atividade antimicrobiana e determinação da concentração mínima inibitória (MICs) dos 2 peptídeos purificados a partir da secreção cutânea do anuro $P$. nattereri frente a linhagens bacterianas Gram-negativas.

Tabela 10. Atividade antimicrobiana e determinação da concentração mínima inibitória (MICs) dos 2 peptídeos purificados a partir da secreção cutânea do anuro $P$. nattereri frente a linhagens bacterianas Gram-positivas. 


\section{LISTA DE FIGURAS}

Figura 1. Estruturas tridimensionais de peptídeos antimicrobianos (PAMs) baseada na composição de seus resíduos de aminoácidos, tamanho e estruturas conformacionais. Lineares: (A) Estrutura em a-hélice da magainina; (B) Forma estendida da indolicidina. Cíclicos: (C) Estrutura enovelada da protegrina; (D) Estrutura folhas $\beta$-pregueadas das defensinas.

Figura 2. Esquema dos mecanismos de resistência contra peptídeos antimicrobianos (PAMs) desenvolvidos por bactérias Gram-negativas. (a) Degradação dos peptídeos por enzimas proteolíticas localizadas na membrana externa (ME). (b) "Escudos" formados por cápsulas de polissacarídeo. (c) Modificações na ME que impedem ou inibem o contato do peptídeo com a membrana interna (MI). (d) Bombas que enviam os peptídeos para dentro ou para fora da bactéria. (e) Supressão da expressão gênica de peptídeos antimicrobianos pela célula hospedeira.....

Figura. 3. Resistência aos antibióticos convencionais em alguns patógenos de humanos. Asteriscos indicam que algumas linhagens destes patógenos atualmente não podem ser tratadas com os fármacos existentes.

Figura 4. Taxas de incidência de novos casos de câncer no mundo

Figura 5. Tipos de câncer de maior incidência no mundo.

Figura 6. Distribuição dos casos de câncer no mundo por nível de desenvolvimento econômico.

Figura 7. Estágios de progressão do câncer: (A). Células normais; (B). Estágio de Iniciação: mutação genética. (C). Promoção: transformação maligna da célula; (D). Progressão: proliferação celular descontrolada. (E). Estágio de Câncer avançado.

Figura 8. Fatores que ocasionam o câncer e características do processo de desenvolvimento do câncer.

Figura 9. Interação de um peptídeo anticâncer com a membrana celular: (A) ancoragem do peptídeo na membrana celular; (B). Início da desestabilização da membrana celular; (C). Desmontagem da bicamada lipídica e formação do canal transmembrana; (D). Fluxo de substâncias para o interior e exterior da célula levando a apoptose. 65 
Figura 10. Multi-estágios da carcinogênese: processos e estratégias de prevenção. A iniciação é caracterizada pela conversão de uma célula normal em uma célula inicializada, em resposta a agentes prejudiciais ao DNA (dano genético indicado por um $\mathrm{X}$ ). A promoção caracteriza-se pela transformação de uma célula inicializada em uma população de células pré-neoplásicas, resultado de alterações na expressão de genes e proliferação celular. A progressão inclui a transformação das células pré-neoplásicas em uma população de células neoplásicas como resultado de alterações genéticas adicionais.

Figura 11. Physalaemus nattereri (Foto de Carlos Candido, Tony Gamble e Lenzi-Mattos)......

Figura 12. Physalaemus nattereri: A) Vista frontal normal; B) lateral; e C). Vista traseira, mostrando as macroglândulas, inguinais (setas), durante comportamento de defesa com exibição das glândulas inguinais. .71

Figura 13. Efeitos da secreção cutânea bruta de $P$. nattereri sobre a taxa de viabilidade celular de células de melanoma murino (B16F10). O tratamento foi realizado com a incubação por $24 \mathrm{~h}$ das células com concentrações crescentes da secreção bruta de $P$. nattereri. A viabilidade celular foi determinada pelo ensaio do MTT. Os dados estão expressos em média \pm SD (desvio padrão) de experimentos realizados em triplicata. ${ }^{*} p<0,01$ comparado com o grupo controle. 100

Figura 14. Efeitos da secreção cutânea bruta de $P$. nattereri sobre a taxa de viabilidade celular de fibroblastos normais (NIH-3T3). O tratamento foi realizado com a incubação por $24 \mathrm{~h}$ das células com concentrações crescentes da secreção bruta de $P$. nattereri. A viabilidade celular foi determinada pelo ensaio do MTT. Os dados estão expressos em média \pm SD (desvio padrão) de experimentos realizados em triplicata. ${ }^{*} p<0,01$ comparado com o grupo controle. 100

Figura 15. Comparação dos efeitos da secreção cutânea bruta de $P$. nattereri sobre as taxas de viabilidade celular de células de melanoma murino (B16F10) e de células de câncer de colo uterino (HeLa). O tratamento foi realizado com a incubação por $24 \mathrm{~h}$ das células com concentrações crescentes $(3,9-500 \mu \mathrm{g} / \mathrm{mL})$ da secreção bruta de $P$. nattereri. A viabilidade celular foi determinada pelo ensaio do MTT. Os dados estão expressos em média \pm SD (desvio padrão) de experimentos realizados em triplicata. 101 
Figura 16. Fotomicrografias de células de melanoma murino (B16F10) da esquerda para a direita o grupo controle (ausência da secreção cutânea bruta) e após o tratamento (presença da secreção bruta de $P$. nattereri). O tratamento foi realizado empregando-se a concentração de $0,79 \mu \mathrm{g} / \mathrm{mL}$, (equivalente ao $\mathrm{IC}_{75}$ para as células $\mathrm{B} 16 \mathrm{~F} 10$ ) com incubação por 24 horas. Pode-se observar no grupo controle a conservação da morfologia celular, observando inclusive uma morfologia celular definida, e membrana citoplasmática integra. No entanto, nas células de melanoma murino quando tratadas com o veneno, observa-se perda da integridade da membrana plasmática e alteração da morfologia celular, apresentando-se de forma arrendondada (setas). Imagens obtidas por microscópio de contraste de fase invertido (Zeiss, Alemanha) com o uso de câmera digital acoplada a ocular do microscópio e o software de aquisição DinoCapture 2.0 Version 1.5.0. Barra $=100 \mu \mathrm{m}$. 102

Figura 17. Efeitos sobre a morfologia celular avaliados por citometria de fluxo em células B16F10 tratadas por $24 \mathrm{~h}\left(\mathrm{p}>0,05, \mathrm{n}=3\right.$ ) com (A) $0 \mu \mathrm{g} / \mathrm{mL}$ (controle) e (B) $0,79 \mu \mathrm{g} / \mathrm{mL}$ (IC $\mathrm{C}_{75}$ ) de secreção bruta de $P$. nattereri . Total de eventos: 10.000 . (dez mil) Legenda: ${ }^{*}=p<0,05 e^{* *}=p<0,01 \ldots \ldots .103$

Figura 18. Efeitos da secreção cutânea bruta $P$. nattereri sobre a membrana plasmática observados com o emprego dos marcadores anexina- $V$ (apoptose) e iodeto de propídeo (necrose). Os parâmetros foram avaliados por citometria de fluxo e os experimentos foram realizados em triplicata. (A) Gráficos bidimensionais utilizando os marcadores anexina- $\mathrm{V}^{+}$e iodeto de propídeo $\left(\mathrm{PI}^{+}\right)$, controle $(0 \mu \mathrm{g} / \mathrm{mL})$ e experimento $(0,79 \mu \mathrm{g} / \mathrm{mL})$ de células incubadas durante $24 \mathrm{~h}$ com secreção bruta de $P$. nattereri. Os gráficos mostram quatro quadrantes (Q1 a Q4) que representam células marcadas apenas com $\mathrm{Pl}^{+}(\mathrm{Q} 1)$, células marcadas com anexina- $\mathrm{V}^{+}$e $\mathrm{Pl}^{+}$(Q2), células marcadas apenas com anexina- $\mathrm{V}^{+}(\mathrm{Q} 3)$ e células não-marcados (Q4). Legenda: anexina- $\mathrm{V}^{+}$indica exposição de fosfatidilserina; $\mathrm{PI}^{+}$indica permeabilidade da membrana plasmática. (B) Os gráficos de barras mostram a percentagem de células em cada quadrante. Legenda: $n s=$ não significativo, ${ }^{* *}=p<0,01$, $* * *=p<0,001$ 105

Figura 19. Efeitos da secreção cutânea bruta $P$. nattereri sobre o potencial de membrana mitocondrial avaliados por citometria de fluxo em células B16F10 tratadas por $24 \mathrm{~h}$. (A) Contagem de fluorescência da rodamina 123 em células de melanoma tratadas e não-tratadas com a secreção bruta de $P$. nattereri. (B) Freqüência de células com potencial de membrana mitocondrial normal e reduzido. ${ }^{*}=\mathrm{P}<0,05,{ }^{* *}=\mathrm{p}<0,01$. Os experimentos foram realizados em triplicata. 106

Figura 20. Efeitos da secreção cutânea bruta de $P$. nattereri sobre as fases do ciclo celular de células de melanoma murino (B16F10) após $24 \mathrm{~h}$ de incubação. As fases do ciclo celular foram analisadas após marcação com iodeto de propídeo e os parâmetros foram avaliados por citometria de fluxo. Os dados são expressos como a percentagem de G1, S e G2/M e representam as médias \pm SD (desvio padrão) dos experimentos realizados em triplicata. $O$ grupo controle corresponde às células nãotratadas e o tratamento refere-se às células incubadas com $0,79 \mu \mathrm{g} / \mathrm{mL}$ da secreção cutânea bruta de P. nattereri...... 107 
Figura 21. Perfil cromatográfico típico do fracionamento da secreção cutânea de Physalaemus nattereri em coluna $\mathrm{C}_{18}$ (Shim-pack CLC-ODS, $6.0 \times 150 \mathrm{~mm}$ ) em sistema HPLC da Shimadzu com emprego de gradiente linear de TFA $0,1 \%(v / v)$ em acetonitrila. A detecção foi monitorada a $216 \mathrm{~nm} e$ a eluição realizada com fluxo de $1 \mathrm{~mL} / \mathrm{min}$. As frações contendo os peptídeos utilizados ao longo do presente trabalho estão indicadas com números que correspondem à sua ordem de eluição e possuem os seguintes tempos de retenção: Fração 1: 3.05; Fração 46: 30.30; Fração 53: 33.15; Fração 121: 67.12; Fração 122: 67.30; Fração 125: 72.99 minutos... 109

Figura 22. Perfil cromatográfico típico do fracionamento da secreção cutânea de Physalaemus nattereri. As frações que apresentaram atividade inibitória sobre a proliferação do fungo Cryptococcus neoformans estão assinaladas com setas vermelhas e possuem os seguintes tempos de retenção: Fração 121: 67.12; Fração 122: 67.30; Fração 125: 72.99 minutos... .111

Figura 23. Perfil cromatográfico típico do fracionamento da secreção cutânea de Physalaemus nattereri. As frações que apresentaram atividade inibitória sobre a proliferação do fungo Candida albicans estão assinaladas com setas vermelhas e possuem os seguintes tempos de retenção: Fração 97: 57.40; Fração 122: 67.30 minutos...... 112

Figura 24. Perfil cromatográfico típico do fracionamento da secreção cutânea de Physalaemus nattereri. As frações que apresentaram atividade inibitória sobre a a proliferação de células de melanoma murino (B16F10) estão assinaladas com setas vermelhas e possuem os seguintes tempos de retenção: Fração 121: 67.12; Fração 122: 67.30; Fração 125: 72.99 minutos. .113

Figura 25. Frequência da composição peptídica da secreção cutânea de Physalaemus nattereri representadas em grupos de massas moleculares monoisotópicas obtidas pela análise por espectrometria de massas tipo MALDI-TOF nos modos refletido (matriz ácido a-ciano 4-hidroxicinâmico) e linear (matriz ácido sinapínico). O ensaio foi realizado empregando-se as frações provenientes de uma única cromatografia...... 115

Figura 26. Distribuição dos componentes moleculares presentes na secreção cutânea de $P$. nattereri detectados em função da suas massas moleculares na análise por MALDI-TOF MS com relação aos seus tempos de retenção em sistema RP-HPLC. 116

Figura 27. Recromatografia de peptídeo de interesse. A fração de massa $3.142 \mathrm{Da}$, foi purificada utilizando-se RP-HPLC em coluna $C_{18}$ (Vydac 218TP54, 4,6 x $250 \mathrm{~mm}$ ) com fluxo de $1 \mathrm{~mL} / \mathrm{min}$. A purificação do peptídeo 3.142 Da por realizada por meio da aplicação do gradiente de $25-50 \%$ de acetonitrila/TFA 0,1\% (v/v) por 30 minutos; A detecção foi realizada a $216 \mathrm{~nm}$. O pico que contem o peptídeo purificado está indicado por sua respectiva massa molecular monoisotópica $[\mathrm{M}+\mathrm{H}]^{+}$..... 117 
Figura 28. Recromatografia de peptídeo de interesse. A fração de massa $3.180 \mathrm{Da}$, foi purificada utilizando-se RP-HPLC em coluna $C_{18}$ (Vydac 218TP54, 4,6 x $250 \mathrm{~mm}$ ) com fluxo de $1 \mathrm{~mL} / \mathrm{min}$. A purificação do peptídeo $3.180 \mathrm{Da}$ foi realizado por meio da aplicação do gradiente de $30-50 \%$ de acetonitrila/TFA $0,1 \%(\mathrm{v} / \mathrm{v})$ por 30 minutos; A detecção foi realizada a $216 \mathrm{~nm}$. O pico que contem o peptídeo purificado está indicado por sua respectiva massa molecular monoisotópica $[\mathrm{M}+\mathrm{H}]^{+}$..... 118

Figura 29. Recromatografia de peptídeo de interesse. As frações de massa 3.208 Da, foram purificadas utilizando-se RP-HPLC em coluna $\mathrm{C}_{18}$ (Vydac 218TP54, 4,6 x $250 \mathrm{~mm}$ ) com fluxo de $1 \mathrm{~mL} /$ min. A purificação do peptídeo 3.208 Da foi realizada por meio da aplicação do gradiente de 30 $50 \%$ de acetonitrila/TFA $0,1 \%(\mathrm{v} / \mathrm{v})$ por 30 minutos; A detecção foi realizada a $216 \mathrm{~nm}$. O pico que contem o peptídeo purificado está indicado por sua respectiva massa molecular monoisotópica $[\mathrm{M}+\mathrm{H}]^{+}$ 118

Figura 30. Espectro de massa do peptídeo de massa molecular 3.142 Da após recromatografia (análise por espectrometria de massa do tipo MALDI-TOF, no modo refletor de íons positivos na faixa de massa de 400 a $8.000 \mathrm{Da})$. 119

Figura 31. Espectro de massa do peptídeo de massa molecular $3.180 \mathrm{Da}$ após recromatografia (análise por espectrometria de massa do tipo MALDI-TOF, no modo refletor de íons positivos na faixa de massa de 400 a $8.000 \mathrm{Da})$.

Figura 32. Espectro de massa do peptídeo de massa molecular 3.208 Da após recromatografia (análise por espectrometria de massa do tipo MALDI-TOF, no modo refletor de íons positivos na faixa de massa de 400 a $8.000 \mathrm{Da})$.

Figura 33. Estruturas primárias das nattererinas 1, 2 e 3 previamente isoladas e caracterizadas quimicamente. 121

Figura 34. Porcentagem de viabilidade celular das linhagens celulares de câncer do colo uterino (HeLa) e fibroblastos murino normal (NIH-3T3) após a incubação por 24 horas com diferentes concentrações do peptídeo nattererina 1 (3180,57 Da).

Figura 35. Porcentagem de viabilidade celular das linhagens celulares de câncer do colo uterino (HeLa) e fibroblastos murino normal (NIH-3T3) após a incubação por 24 horas com diferentes concentrações do peptídeo nattererina $2(3208,07 \mathrm{Da})$. 123

Figura 36. Porcentagem de viabilidade celular das linhagens celulares de câncer do colo uterino (HeLa) e fibroblastos murino normal (NIH-3T3) após a incubação por 24 horas com diferentes concentrações do peptídeo nattererina 3 (3142,29 Da). 123 
Figura 37. Fotomicrografias das células HeLa (células de câncer de colo do útero, no painel superior) e células NIH-3T3 (células de fibroblastos normais, no painel inferior) e da esquerda para a direita, observa-se o grupo controle (ausência do peptídeo-teste) e os tratamentos com $128 \mu \mathrm{M}$ e $0,125 \mu \mathrm{M}$. Imagens obtidas por microscópio de contraste de fase invertido (UNICO, EUA) com o uso de câmera digital acoplada a ocular do microscópio e o software de aquisição Motic Images Plus 2.0. Barra $=100$ $\mu \mathrm{m}$. 


\section{LISTA DE ABREVIATURAS}

$[\mathrm{M}+\mathrm{H}]^{+}$. Massa molecular monoisotópica.

Abs. Absorbância.

ACN. Acetonitrila.

ATP. Adenosina trifosfato.

ATTC. American Type Culture Collection.

B16F10. Célula tumoral de melanoma murino

CFU. Unidade formadora de colônia.

DMEM. Dulbecco/Vogt modified Eagle's minimal essential medium.

DMSO. Dimetilsulfóxido.

DNA. Ácido desoxorribonucléico.

DST. Doença sexualmente transmissível.

DTT. Ditiotreitol.

EDTA. Ácido etilenodiaminotetraacético.

FITC. Isotiocianato de fluoresceína.

FACS. Fluorescence Activated Cell Sorter.

FGF. Fator de crescimento de fibroblasto.

FSC. Forward Scatter (Dispersão frontal relativo a tamanho celular).

$\mathrm{HC}_{50}$. Concentração capaz de promover $50 \%$ de hemólise.

HCCA. Ácido a-ciano-4-hidroxicinâmico.

IC $_{50}$. Concentração que inviabiliza $50 \%$ das células.

$I \mathbf{C}_{75}$. Concentração que inviabiliza $75 \%$ das células.

MALDI-TOF. Matrix-assisted laser desorption/ionization time-of-flight.

MIC. Concentração inibitória mínima.

MTT. Brometo de 3-(4,5-dimetiltiazol-2-il)-2,5-difeniltetrazólio.

$\mathbf{m} / \mathbf{z}$. Massa/carga.

NIH-3T3. Células de fibloblastos murino normal.

nM. Nanomolar.

PAMs. Peptídeos antimicrobianos.

RP-HPLC. Reversed-phase high performance liquid chromatography.

SSC. Side Scatter (Dispersão lateral relativo à granulosidade celular).

TFA. Ácido trifluoroacético.

WHO. World Health Organization (Organização Mundial de Saúde). 


\section{RESUMO}

As secreções cutâneas de anuros são fontes naturais de peptídeos antimicrobianos. A realização de novas pesquisas nessa área tem revelado que alguns peptídeos com atividade antimicrobiana também apresentam efeitos tóxicos sobre células tumorais. O objetivo do presente estudo foi investigar o potencial terapêutico da secreção cutânea de Physalaemus nattereri sobre células tumorais e determinar os mecanismos da ação citotóxica sobre céluluas de melanoma murino da linhagem B16F10. Nossos resultados demonstraram que a secreção bruta reduz a viabilidade de células B16F10, causando alterações na morfologia celular, (p.ex., arredondamento e encolhimento), ruptura da membrana plasmática, redução do potencial de membrana mitocondrial e parada do ciclo celular na fase $\mathrm{S}$; tais mudanças em conjunto sugerem que as células tumorais morreram por apoptose. A secreção cutânea também foi submetida ao fracionamento cromatográfico empregando RP-HPLC e as frações eluídas foram avaliadas quanto à suas atividades antiproliferativas e antimicrobiana. Três frações ativas exibiram componentes de massa molecular compatíveis com peptídeos. Os três componentes majoritários presentes em tais frações foram purificados por RP-HPLC e analisados por MALDI-TOF/MS. Tais peptídeos mostraram-se ativos sobre bactérias e células tumorasi e foram identificados como pertencentes ao grupo das nattererinas, peptídeos antibacterianos previamente isolados desse animal por nosso grupo.

Embora, o mecanismo específico envovlido na redução da viabilidade celular e citotoxicidade após o tratamento com essa secreção bruta ainda não seja conhecido, podemos supor que a atividade de moléculas, como peptídeos, presentes nessa secreção seja efetivos contra as células de melanoma murino (B16F10). Considerando-se a necessidade crescente por novas drogas anticâncer, o presente estudo fortemente reforça a validade do uso da secreção cutânea de $P$. nattereri como uma rica fonte de novas moléculas anticâncer, principalmente peptídeos.

PALAVRA CHAVE: Physalaemus nattereri; melanoma, citotóxico, secreção cutânea, anuro. 


\begin{abstract}
Anuran secretions are rich natural sources of antimicrobial peptides. The emergence of new research in this area has shown that some peptides with antimicrobial activity also exert toxic effects against cancer cells. The aims of this study were to investigate the therapeutic potential of Physalaemus nattereri skin secretion against cancer cells, and to verify the mechanisms of its cytotoxic action on the murine melanoma cell line B16F10. Our results demonstrated that the crude secretion reduces the viability of B16F10 cells, causing changes in cell morphology (e.g., round shape and structure shrinkage), rupture of the plasma membrane, reduction in mitochondrial membrane potential, fragmentation of DNA, and cell cycle arrest in Sphase; together, these changes suggest that tumor cells die by apoptosis. This skin secretion was also submitted to chromatographic fractionation using RP-HPLC and the eluted fractions were assayed for antiproliferative and antibacterial activities. Three active fractions showed molecular masses components with a molecular range compatible to peptides. Thes major petidic components present on these fractions were purified by RP-HPLC and analysed by MALDI-TOF/MS. These peptides were active against bacteria and cancel cells, and were identified as nattererins, antibacterial peptides previously isolated from this animal by our group.

Although, the specific mechanism causing the reduction in cell viability and cytotoxicity after treatment with the crude secretion is still unknown, we can consider that the activity of molecules, such as peptides, within the secretion is effective against murine melanoma (B16F10) tumor cells. Considering the growing need for new anticancer drugs, the present data strongly reinforce the validity of crude secretion of $P$. nattereri as a rich source of new anticancer molecules, mainly peptides.
\end{abstract}

Keywords: Physalaemus nattereri; melanoma; cytotoxicity; skin secretion; anurans. 
1. Introdução 


\section{Considerações iniciais}

A classe Amphibia abrange três ordens: Anura (sapos, rãs e pererecas), Caudata (salamandras) e Gymnophiona (cecílias ou cobras-cegas) (Duellman \& Trueb, 1994). Existem 7.044 espécies de anfíbios descritas em todo o mundo (Frost 2015). (Amphibian Species of the World http://research.amnh.org/vz/herpetology/amphibia/).

No território brasileiro, são 943 espécies descritas, das quais 913 pertencem à ordem Anura (Sociedade Brasileira de Herpetologia http://www.sbherpetologia.org.br/). Devido às adaptações comportamentais, fisiológicas e morfológicas, esses animais conseguiram estarem presentes, tanto no ambiente terrestre como no aquático. A pele, uma de suas maiores adaptações, possui diversas funções, tais como: proteção contra abrasão, respiração cutânea, osmorregulação, termorregulação e secreção de substâncias protetoras (Colon et al., 2009).

\subsection{Substâncias bioativas em anfíbios}

Devido à constante presença de microrganismos patogênicos, os organismos multicelulares apresentam um aparato de resistência chamado de imunidade inata (Rinaldi, 2002). Como a resposta imune patógeno-específica ocorre lentamente, a imunidade inata age como uma primeira linha de defesa, na qual há a produção de moléculas antimicrobianas pelas células epiteliais, atuando rapidamente e controlando o crescimento de um amplo espectro de microrganismos (Colon et al., 2009).

A defesa contra microrganismos patogênicos é importante porque a pele desses animais é um ambiente favorável para o crescimento de bactérias e fungos (Toledo \& Jared, 1995). Existem dois tipos de glândulas na pele da maioria dos anfíbios: glândulas mucosas e glândulas granulosas. As glândulas mucosas, menores e em maior número, são responsáveis por manter a pele úmida e escorregadia por meio da secreção de mucinas. As glândulas granulosas, por outro lado, são maiores e apresentam-se em menor número, as quais estão localizadas, principalmente, na parte dorsal da pele desses animais. As glândulas granulosas são responsáveis pela 
produção, armazenamento e liberação de moléculas bioativas, como peptídeos antimicrobianos (Colon et al., 2009).

Sabe-se que as secreções provenientes de pele desses animais, na sua grande maioria, possuem um grande número de compostos químicos tais como esteróides, alcalóides, aminas biogênicas, proteínas e peptídeos. Estes compostos são responsáveis por apresentarem diferentes papeis na regulação das funções fisiológicas da pele dos anuros em geral, bem como nas suas estratégias de defesa contra predadores e patógenos, sendo alguns deles semelhantes aos hormônios gastrintestinais, aos neurotransmissores e a fatores de liberação de hormônios presentes nos mamíferos. Alguns gêneros de anfíbios produzem/secretam maior abundância e variedade dessas moléculas que outros, como ocorrem em Phyllomedusa e Xenopus (Lenzi-Mattos et al., 2005; Toledo et al., 1995; Clark et al., 1997; Van zoggel et al., 2012)

O interesse crescente na pesquisa acerca dos peptídeos de anfíbios tem aumentado nos últimos anos, devido ao seu potencial terapêutico, e também pelo fato de que muitos são formados em tecidos com a mesma origem embrionária, tais como a pele, o sistema gastrintestinal e o cérebro (Simmaco et al., 1998).

A utilização da secreção cutânea da pele de anfíbios por parte de algumas comunidades indígenas tem sugerido um eventual potencial farmacológico de certos princípios ativos que estas secreções possam conter (Gorman, 1993). Alguns trabalhos produzidos pela comunidade cientifica investigaram a utilização desses compostos como, por exemplo, os peptídeos opióides encontrados na secreção de P. bicolor (Mignona et al., 1992; Daly et al., 1992).

Essas moléculas parecem ser exclusivas dos hilídeos sul-americanos e neotropicais da subfamília Phyllomedusinae e apresentam propriedades farmacológicas relevantes, uma vez que são seletivos a receptores $\mu$ e $\delta$-opioides (Erspamer et al., 1989; Negri et al., 1992).

Várias espécies de anfíbios encontrados nas Américas tem sido alvo de estudos com a finalidade de determinar se suas secreções cutâneas contem peptídeos com atividades em uma variedade de tipos de músculos lisos, secreção exócrina, e sistema nervoso central (Erspamer et al., 1986).

Moléculas bioativas e com propriedades antimicrobianas podem ser isoladas de organismos de todos os reinos. Uma importante consideração sobre essas 
moléculas é em relação à forma como atua, o mecanismo de ação consiste no grau com que essas moléculas fazem a distinção/seleção entre as células microbianas e as hospedeiras. Sabe-se que a composição das membranas de procariotos e de eucariotos não são estática e nem a estrutura é simétrica. A seletividade entre as células microbianas e as de mamíferos como alvos para essas moléculas bioativas, baseia-se na configuração dos componentes da bicamada fosfolipídica. Membranas celulares compostas predominantemente por fosfotidilglicerol, cardiolipina ou fosfatidilserina tendem a ser altamente eletronegativas; sendo essas composições encontradas em alguns patógenos bacterianos, fator que proporciona a aproximação entre as cargas positivas, por exemplo, dos peptídeos e as negativas da superfície da bicamada. Ao contrario, bicamadas enriquecidas com fosfatidiletanolamina, fosfatidilcolina ou esfingomielina, (e esteróis) comumente encontrados em membranas de eucariotos superiores, são geralmente neutras, tornando-as alvejadas em menor grau por essas moléculas bioativas. (Negri et al., 1992)

Um caso de substância bioativa, é a secreção do anuro Phyllomedusa bicolor que além das propriedades antibimicrobianas, e do fortalecimento do sistema imunológico, possui atividade no tratamento do mal de Parkinson, AIDS, câncer, depressão e outras doenças. Isso tudo foi verificado pela ação da dermorfina e a deltorfina (Negri et al., 1992).

Com isso, nos últimos anos, estudos vêm demonstrando que a pele dos anfíbios é a fonte de uma vasta gama de substâncias biologicamente ativas, sendo algumas delas de grande relevância farmacológica e clínica.

\subsection{Peptídeos antimicrobianos (PAMs)}

O termo "peptídeos antimicrobianos" (PAMs) é usado para descrever um grande número de pequenas proteínas que pode matar ou inibir o crescimento de vários microorganismos. Eles foram descobertos no final da década de 1980 em uma espécie de sapo Africano: Xenopus laevis e assim comprovados sua eficácia por fornecer uma proteção natural contra infecções. Esta classe de peptídeos catiônicos, como por exemplo, as magaininas, mostraram um amplo espectro de ação, possuindo atividade antifúngica e antiparasitária (Zasloff et al., 1987). 
Nas décadas seguintes, uma variedade de diferentes peptídeos, peptídeos também chamado de "peptídeos de defesa do hospedeiro", foram identificados e isolados de muitos organismos, incluindo plantas, bactérias, fungos, insetos e vertebrados. Assim, percebeu-se que os PAMs desempenham um papel importante no sistema imune inato exibindo a primeira linha de defesa contra infecções (Bulet et al., 2004).

Nos mamíferos, essas regiões são conservadas e os PAMs estão localizados principalmente em superfícies epiteliais e não-epiteliais, na qual eles mantêm a função de impedir invasões microbianas (Varoga et al., 2005).

Os PAMs presentes na pele desses anuros estão envolvidos na manutenção das funções bem como também, são responsáveis pela manutenção das meninges cerebrais (Bergman et al., 2006; Brandenburg et al., 2009).

Os PAMs são caracterizados pela sua pequena dimensão (12-50 aminoácidos), os resíduos de arginina e lisina são responsáveis por sua carga positiva e uma estrutura anfipática que Ihes permite interagir com membranas microbianas (Zaiou et al., 2007). Possuem um grande número de resíduos hidrofóbicos, usualmente exibem carga líquida positiva, conformação em a-hélice anfipática, momento hidrofóbico alto e uma ampla face apolar em contraste com uma pequena face polar (Hancock \& Chapple, 1999; Nascimento et al., 2003).

Estruturalmente a classificação dos PAMs (Figura 1) sugerida por Lai \& Gallo (2009) é baseado na composição de seus resíduos de aminoácidos, tamanho e estruturas conformacionais sendo divididos em: (1) Peptídeos com uma estrutura $\boldsymbol{\alpha}-$ hélice como as cecropinas, metilinas, magaininas e dermaseptinas; (2) Peptídeos com estrutura $\beta$-folha estabilizada por pontes dissulfeto entre resíduos Cys conservados como as $\beta$-defensinas humanas. Alguns peptídeos desta classe desistabilizam as membranas bacterianas por meio da formação de poros toroidais como descrito no peptídeo protegrina 1 porcina. Este peptídeo possui, a parte hidrofóbica interage com o núcleo hidrofóbico da bicamada permitindo que as cadeias laterais catiônicas de arginina possam interagir com os grupos fosfato aniônicos. $\mathrm{Na}$ protegrina, os resíduos de arginina estão localizados nas extremidades da $\beta$-folha o que torna a molécula anfipática; (3) Peptídeos de estrutura estendida que muitas vezes possui um único aminoácido predominante 
sendo arginina, triptofano ou resíduos de prolina em altas proporções, como a Indolicidina extraída a partir de grânulos citoplasmáticos de neutrófilos bovinos constituído por apenas 13 resíduos ricos nos aminoácidos: triptofano (cinco resíduos), prolina (três resíduos e arginina (dois resíduos); e também o peptídeo temporinas, primeiramente isolados da espécie Rana temporaria. (4) peptídeos com pontes dissulfeto formando estruturas loop C-terminal como a bactenecina, brevininas, e esculetinas. peptídeo catiônico de neutrófilos bovinos que apresenta 12 resíduos de aminoácidos sendo quatro resíduos de arginina, dois resíduos de cisteína e seis de outros resíduos hidrofóbicos. Os dois resíduos de cisteína são responsáveis pela ligação dissulfeto formando uma estrutura em loop (Subbalakshmi \& Sitaram, 1998; Friedrich et al., 1999; Oren et al., 1999; Wu \& Hancock, 1999; Staubitz et al., 2001; Brogden, 2005; Lai \& Gallo, 2009; Nguyen et al., 2011).
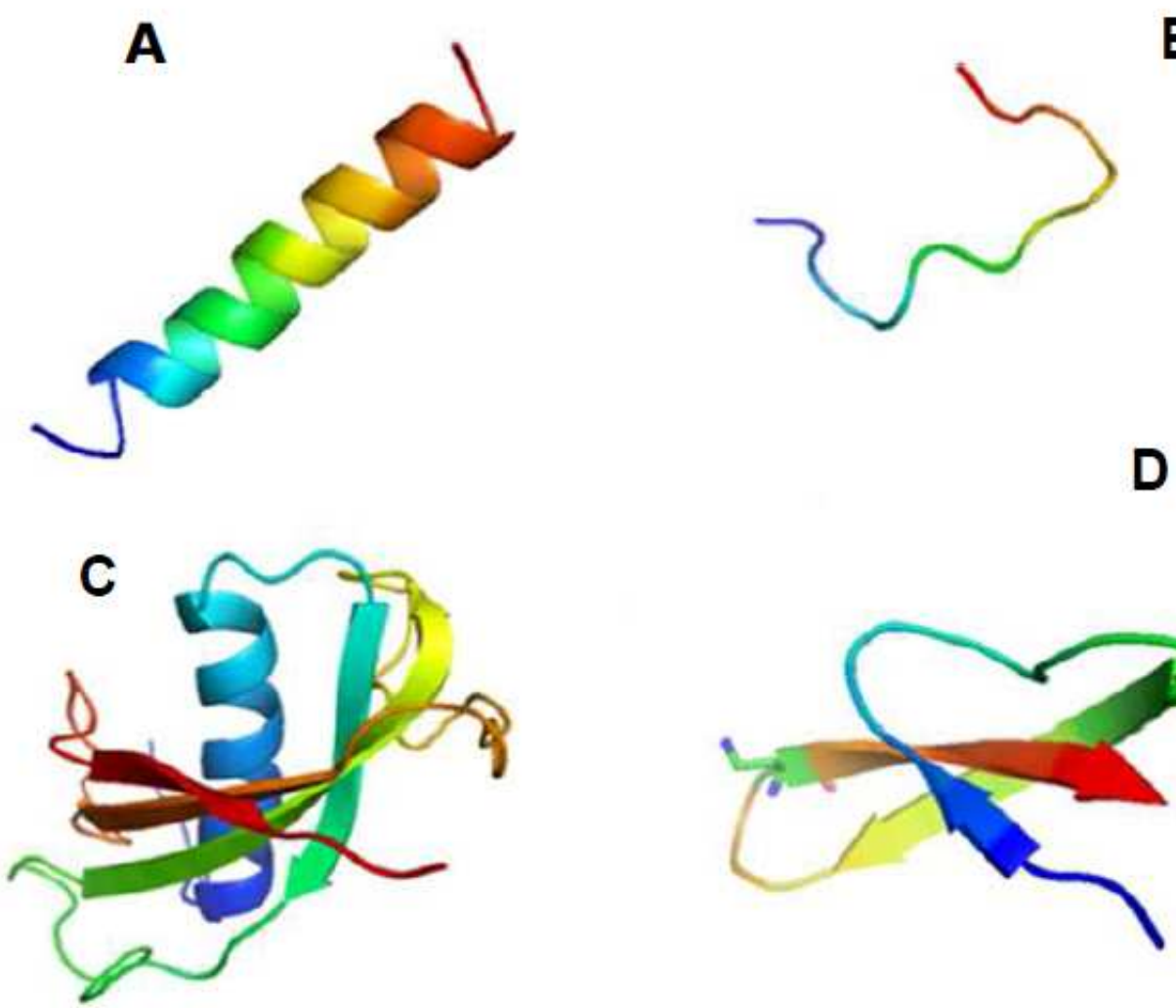

B
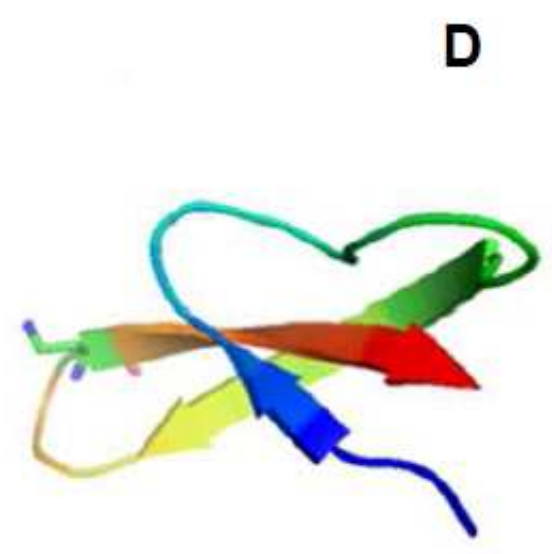

Figura 1. Estruturas tridimensionais de peptídeos antimicrobianos (PAMs) baseada na composição de seus resíduos de aminoácidos, tamanho e estruturas conformacionais. Lineares: (A) Estrutura em a-hélice da magainina; (B) Forma estendida da indolicidina. Cíclicos: (C) Estrutura enovelada da protegrina; (D) Estrutura folhas $\beta$-pregueadas das defensinas. 
Avaliação dos efeitos citotóxicos e antiproliferativos da secreção cutânea e de peptídeos bioativos do anuro Physalaemus nattereri (Steindachner, 1863)

Com base nos resíduos primários e secundários e considerando as diferenças estruturais, e o seu potencial efeito antimicrobiano nas células hospedeiras, os PAMs podem ser divididos em diferentes famílias. Em células de mamíferos, foram descritas três famílias: defensinas, Catelicidinas e histatinas (ver tabela 1). (De Smet et al., 2005).

Tabela 1. Principais membros dos PAMs de mamíferos e suas famílias.

\section{Exemplo, Localização, Classe, Família, Humana}

- Defensinas a-defensina HNP-1-4, neutrófilos, células NK (Lehrer et al., 2012).

- HD-5, HD-6 células Paneth

- $\quad \beta$-defensina-1-4 HBD amplamente distribuído (Pazgier et al., 2007).

- Leucócitos e células epiteliais (língua, córnea, pele, glândulas salivares, rins, esôfago e do trato respiratório).

- $\Theta$ - defensina não determinado em leucócitos de primatas (Tongaonkar et al., 2011).

- Catelicidinas LL- 37 amplamente distribuída (Bucki et al., 2010).

- Leucócitos e células epiteliais (epitélios da pele, do intestino, pulmões, e tecido cerebral).

- Histatinas HIS saliva -1, 3 ou 5, submandibular (Wiesner et al., 2010).

○ Glândulas sublinguais e parótida.

Fonte: (De Smet et al., 2005).

No entanto sabe-se que muitos outros peptídeos foram identificados, além destas três principais famílias (defensinas, catelicidinas, histatinas), por exemplo, a RNase 7, hepcidina, lactoferrina e as citadas anteriormente.

Uma descrição geral dos PAMs existentes atualmente pode ser visualizada pela base de dados de peptídeos antimicrobianos (PAMs) (Wang et al., 2009). As defensinas são amplamente expressas, mostram atividade, antifúngica e antiviral e bactericida e são abundantes principalmente em células e tecidos envolvidos na defesa do hospedeiro. Devido à presença de seis cisteínas conservadas na estrutura primária das defensinas, sua estrutura e função específica são determinadas por três pontes de dissulfureto. De acordo com a posição das cisteínas, as defensinas foram assim classificadas como $\alpha, \beta$ e $\theta$-defensinas. Nos mamíferos, as 
concentrações elevadas de defensinas foram detectados na pele e das mucosas. Além disso, elas fornecem proteínas granulares em granulócitos neutrófilos (cerca de $30 \%$ ) e também em células do intestino delgado (Ganz et al., 2003). Membros da família relacionadas as defensina foram identificados também em plantas (Arabidopsis thaliana) e não-vertebrados (Bulet et al., 2004; Stotz et al., 2009).

Catelicidinas são definidas por um N-terminal altamente conservado Cathelina pró-domínio e estruturalmente um domínio variável no C-terminal. Elas foram identificados em várias espécies, com Inter-espécies substancial, variação no número de membros da família. Em humanos, o gene codifica uma proteína cathelicidina precursor inativo (HCAP18) que é processada liberando um peptídeo com 37 resíduos de aminoácidos com duas leucina no início (LL-37) do C-terminal da proteína precursora (Gudmundsson et al., 1996). As catelicidinas são produzidos pelos leucócitos, mas estudos recentes têm mostrado que eles tenham uma ampla distribuição, incluindo o tecido epitelial e tecido cerebral (Frohm et al., 1997; Huttner et al., 1999). A expressão não é, portanto, limitada a órgãos linfóides ou leucócitos. As catelicidinas possuem atividade contra as bactérias Gram-positivas e Gramnegativas (Nizet et al., 2003). Também possuem atividade antiparasitária contra Trypanosoma cruzi. (McGwire et al., 2003). Resultados recentes mostraram também o peptídeo cathelicidina em plantas (Tarasov, et al., 2009). Em não vertebrados, ainda não foram detectados.

A terceira família principal de PAMs em mamíferos, conhecida como histatinas, inclui vários peptídeos ricos em histidinas. Com características de serem bem pequenos, e catiônicos. Eles são constitutivamente produzido e secretado pela glândula salivar bucal tal como as glândulas parótidas, submandibulares e sublinguais (Ahmad et al., 2004).

Possuem um efeito bactericida potente e também uma acentuada atividade fungicida e desempenham um papel importante, na manutenção da saúde bucal, limitando assim, infecções na cavidade oral (De Smet et al., 2005). Histatinas até agora têm sido isoladas somente a partir de seres humanos e primatas apenas (Padovan et al., 2010).

A expressão de PAMs é mediada principalmente pelos receptores de reconhecimento de padrões (PRR), que ao reconhecer regiões conservadas do patógeno associadas a estruturas moleculares, como componentes da parede 
celular bacteriana, o DNA bacteriano ou proteínas do envelope viral. Por exemplo, ambos os receptores Toll-like e formil receptores estão envolvidos na expressão de PAMs (Froy et al., 2005; Braun et al., 2011).

Dessa forma, peptídeos antimicrobianos (PAMs) constituem um importante componente do sistema imune inato em organismos em toda a escala evolutiva (Sai et al., 2001). O conjunto diversificado desses peptídeos antimicrobianos (PAMs) tem sido alvo de estudo por parte de alguns pesquisadores, ao longo das últimas décadas ( $\mathrm{Li}$ et al., 2007). À identificação de centenas desses PAMs, favorece de certa forma, quando pensamos e comparamos o uso convencional de antibióticos que tem desenvolvido resistência ao longo do tempo, tornando assim, os PAMs "atraentes" considerando seu potencial, baseado no seu mecanismo de ação (Sang et al., 2008). Muitos microrganismos têm apresentado resistência tanto contra os já bem estabelecidos antibióticos de uso convencional quanto contra os antibióticos de última geração (Austin D. J. et al., 1999).

\subsection{Antibióticos convencionais e sua utilização na terapia}

Os antibióticos foram originalmente definidos como substâncias produzidas por microorganismos, que em pequenas concentrações inibem o crescimento de outros microorganismos. (Denyer et al., 2011). Esta definição atualmente ultrapassada implica em uma ocorrência natural dos antibióticos, excluindo as substâncias resultantes de síntese química. $O$ uso do termo antibiótico vem mudando com o tempo, pois, muitas substâncias sintéticas análogas foram desenvolvidas com as mesmas características dos antibióticos tradicionais tais como potência, baixa toxicidade e ação sistêmica (Denyer et al., 2011).

A definição mais aceita hoje é a de uma substância produzida por microorganismos ou por uma substância semelhante, produzida integralmente ou parcialmente por síntese química, que em baixas concentrações inibe o crescimento ou mata outros microorganismos (Denyer et al., 2011)

Contudo, nos dias de hoje, muitas cepas de bactérias patogênicas resistentes a antibióticos tem sido cada vez mais prevalentes nos hospitais e nas comunidades e a velocidade no desenvolvimento de novos antibióticos tem sido lenta, em função 
do baixo resultado econômico em relação a outras drogas de uso prolongado. (Fischbach \& Walsh, 2009).

Com o advento do uso clínico de sulfonamidas, descoberta em 1933, antibióticos de amplo espectro de ação, proporcionou modificações na forma de tratamento dessas infecções. Neste sentido, ocorreu a transição da terapia antimicrobiana patógeno específica para a terapia não específica, conhecida também como terapia empírica (Casadevall, 1996). Esta terapia, amplamente difundida até os dias atuais (Pogue et al., 2011), permite o tratamento imediato e efetivo de uma infecção bacteriana sem a necessidade da identificação do patógeno envolvido (Casadevall, 1996).

O aparecimento de cepas bacterianas Gram-positivas e Gram-negativas multirresistentes conhecidas como "super bugs" ou super bactérias induziu a necessidade imediata para o desenvolvimento de novas classes de agentes antimicrobianos como, por exemplo, os peptídeos antimicrobianos (Gwynn et al., 2010; Nguyen et al., 2011). Estas moléculas vêm demonstrando a possibilidade de utilização como importantes ferramentas moleculares no uso como antimicrobianos. Inúmeras pesquisas nas últimas décadas, em relação a sua biossíntese, atividade contra microrganismos, mecanismo de ação e potencial aplicação clínica tem sido realizados (Lofgren et al., 2008; Nguyen et al., 2011).

Sabendo que os microrganismos produtores de antibióticos existentes no meio ambiente apresentam mecanismos de autoproteção codificados geneticamente, a transferência de genes de resistência de bactérias nãopatogênicas ou de baixa patogenicidade para microrganismos patogênicos provavelmente é um fenômeno comum. Este fenômeno natural ganha importância, porém, com a utilização das substâncias antimicrobianas, por sua ação selecionadora de microrganismos resistentes. $O$ emprego das drogas antimicrobianas em seres humanos e animais possibilitam a disseminação destes microrganismos, que é tanto maior quanto mais intenso for este uso.

Casellas e Tome (Casellas JM, \& Tome G. 1998) mencionam um exemplo recente deste fato. $\mathrm{Na}$ década de 90 , não existiam cepas de Klebsiella e estafilococos meticilina-resistentes com resistência à ciprofloxacina na Argentina e a maior parte das estirpes de $P$. aeruginosa e Acinetobacter era sensível a esta quinolona. Com o emprego caótico deste antimicrobiano em Buenos Aires, em 1998 
Avaliação dos efeitos citotóxicos e antiproliferativos da secreção cutânea e de peptídeos bioativos do anuro Physalaemus nattereri (Steindachner, 1863)

$30 \%$ das Klebsiella, $50 \%$ das $P$. aeruginosa e estafilococos e $80 \%$ dos Acinetobacter tornaram-se altamente resistentes à ciprofloxacina.

$\mathrm{Na}$ Islândia, Arason et al., 1996 também observaram uma associação entre o uso de antimicrobianos, especialmente penicilinas, co-trimoxazol e eritromicina, e pneumococos resistentes em crianças portadoras do germe na nasofaringe.

A importância das substâncias antimicrobianas no aumento do fenômeno da resistência reside no seu papel selecionador dos exemplares resistentes, através da pressão seletiva resultante de seu emprego clínico (humano e veterinário), industrial (conservação de alimentos), comercial (engorda de animais) e experimental (BuuHoi A. et al., 1986; Linton AH. 1984; Saunders JR. 1984; Suassuna I, \& Suassuna IR. 1971; Witte W. 1998).

A pressão seletiva do uso de antimicrobianos exerce papel fundamental na disseminação da resistência, conforme bem conhecido no ambiente hospitalar e, mesmo, no meio extra-hospitalar. Exemplo desta última assertiva é o encontro de resistência ao cloranfenicol em 30 a 50\% de isolamentos de E. coli na Indonésia, onde o cloranfenicol é utilizado largamente como droga de primeira escolha para o tratamento de diarréias. Ao contrário, nos Estados Unidos, onde o uso deste antibiótico é feito com rigor, a resistência ao cloranfenicol (Levy SB. 1982).

A resistência das diversas espécies bacterianas aos antimicrobianos é extremamente variável entre os países, regiões e também existe essa variação se considerarmos a origem hospitalar ou comunitária das estirpes. Algumas espécies apresentam resistência amplamente difundida em todo o mundo, como é o caso do Staphylococcus aureus, enquanto que outras mantêm em todos os países notável sensibilidade às drogas ativas, como exemplificado pelo Streptococcus pyogenes e as penicilinas (Alanis, 2005; Sykes, 2010).

Como consequência adicional do uso inadequado da penicilina, descoberta em 1929, (Fleming A. 1980) em que, após apenas um ano de uso observou-se um número significante de cepas de $S$. aureus resistentes a este medicamento e, em $1948,50 \%$ das cepas hospitalares isoladas já se mostravam resistentes a inúmeros tipos de antibióticos, atingindo níveis mundiais de 80\% entre 1955-1957 (Alanis, 2005; Sykes, 2010).

À medida que outros agentes como a eritromicina, cloranfenicol e tetraciclinas tornaram-se medicamentos de escolha no tratamento de $S$. aureus já resistente à 
penicilina, a resistência bacteriana a esses agentes também cresceu, limitando seu uso clínico por volta de 1950. O mesmo ocorreu com a meticilina, derivado semisintético do núcleo ativo da penicilina (ácido 6-aminopenicilânico), que assumiu importante papel no controle da infecção de $S$. aureus. Bactérias resistentes a meticilina causaram inúmeros casos de infecção hospitalar na Europa em 1960 (Kollef \& Fraser, 2001). A resistência de $S$. aureus a meticilina atingiu cerca de $60 \%$ em 2011, cujas cepas são clones dos isolados endêmicos brasileiros (Rossi, 2011).

Mais de 60 anos se passaram depois da descoberta dos primeiros antibióticos para uso clínico e sua utilização tem exercido uma imposição adicional no desenvolvimento de formas de resistência bacteriana. Da mesma forma, novas classes de antibióticos têm sido descobertas e classificadas de acordo com seu mecanismo de ação. Entretanto, um por um, estes agentes antimicrobianos vêm se tornando ineficientes frente ao surgimento de bactérias a eles resistentes (Fischbach \& Walsh, 2009). Além de afetar pacientes hospitalizados e imuno deprimidos (Bello et al., 2011), na última década essas bactérias vêm se espalhando na comunidade e provocando doenças severas em pacientes previamente saudáveis (Alanis, 2005).

\subsection{Utilização dos PAMs na terapia}

Peptídeos antimicrobianos (PAMs) são uma nova classe de "antibióticos" e são definidos como pequenas moléculas protéicas que contém até 50 resíduos de aminoácidos e oferecem uma rápida e imediata resposta ao microorganismo invasor (Bartlett et al., 2002; Huang et al., 2010). Apesar das variações na estrutura tridimensional, massa, tamanho e características biológicas, a maioria dos peptídeos antimicrobianos pode ser anfifílica, apresentando superfícies hidrofílicas e hidrofóbicas (Tincu \& Taylor, 2004; Brogden \& Brogden, 2011). As características anfifílica e catiônica são importantes para sua capacidade antimicrobiana de se ligar a superfícies microbianas aniônicas, tais como, lipopolissacarídeos (LPS) (Wang et al., 2010). Duas características físicas para PAMs são comuns: uma carga catiônica e uma proporção significativa de resíduos hidrofóbicos. A cationicidade dos PAMs requer interações com porções carregadas negativamente sobre outras biomoléculas tais como lipídeos da membrana externa, ácidos nucléicos e proteínas fosforiladas (Nguyen et al., 2011). 
Por isso a sua especificidade é dada baseada no seu mecanismo de ação, que apesar das diferenças existentes, a especificidade esta relacionada basicamente com a alteração da permeabilidade da membrana plasmática dos microorganismos. Esta capacidade de interagir com as membranas lipídicas é atrelada a diversas características dessas moléculas como as propriedades bioquímicas definidas pela seqüência de aminoácidos (carga, estrutura anfipática e hidrofobicidade) e conformação tridimensional (geometria, ângulo polar e conformação molecular). Em todos os modelos clássicos de interação dos PAMs com membranas celulares, aparentemente, é necessária uma atração do peptídeo pela superfície da membrana microbiana por força eletrostática ou devido à presença de cargas residuais presentes na superfície do microorganismo. A partir desta interação com os lipídios da bicamada, o peptídeo altera a organização e a permeabilidade da membrana fosfolipídica causando a despolarização e desequilíbrio osmótico celular por meio da sua interação (Brogden, 2005).

Ainda que o modo de ação possa envolver a perturbação da integridade da membrana citoplasmática bacteriana de diferentes maneiras, outros mecanismos foram caracterizados tendo como alvo os principais processos celulares, incluindo DNA e síntese protéica, enovelamento de proteínas, atividade enzimática e síntese da parede celular. Em alguns PAMs conhecidos, como a magainina e a indolicidina, foi constatado que eles podem ter vários modos de ação a fim de aumentar a sua eficiência e evitar potenciais mecanismos de resistência (Nguyen et al., 2011).

Contudo, independente do mecanismo de ação, a maioria dos PAMs age contra microorganismos por meio de um mecanismo que abrange a ruptura da membrana havendo assim, a formação de poros, permitindo assim, o efluxo de íons e nutrientes fundamentais. O efluxo é um mecanismo de defesa celular generalizado com consequências clínicas para tratamentos antimicrobianos. A interação inicial entre os peptídeos e a membrana da célula microbiana permite adentrar na célula para se unir a moléculas intracelulares, resultando na inibição da biossíntese da parede celular inibição da atividade enzimática, DNA, RNA e síntese de proteínas (Peters et al., 2010; Wood \& Cluzel, 2012).

Um requisito necessário para a eficácia de um agente antimicrobiano é baseado na sua resposta a toxicidade seletiva para o alvo microbiano, sendo uma característica singular. Outra característica importante, é que no seu mecanismo de 
ação no seu contato com células microbianas não apresentem toxicidade para as células de mamíferos (Peters et al., 2010). Uma importante característica observada é que muitos PAMs mostram especificidade notável para procariontes com toxicidade para as células eucarióticas (Zasloff, 1992; Tincu \& Taylor, 2004). A toxicidade de peptídeos antimicrobianos contra células eucarióticas pode ser o principal obstáculo para a sua aplicação clínica (Huang, 2000). Os peptídeos atuam em membranas bacterianas ou outros alvos generalizados, contestando a maioria dos antibióticos que geralmente têm como alvo proteínas específicas (Nguyen et al., 2011).

Ao longo dos anos, muitas pesquisas vêm sendo realizadas acerca do descobrimento de novos PAMs. Levando em consideração o tamanho e estrutura primária do peptídeo, já é possível por meio de técnicas moleculares sintetizá-los em laboratório e utilizá-los como fármacos.

Uma das estratégias utilizadas na síntese de PAMs é o desenho in silico que se baseiam em seqüência peptídeos antimicrobianos depositados em bancos de dados. Isso é possível de acontecer, retirando-os de uma proteína maior, como foi feito por Okubo e colaboradores (2012). A proteína $B m L A O$, uma enzima multifuncional L-amino oxidase ( $\mathrm{LAO}$ ) com atividade antibacteriana, e isolada da serpente Bothrops mattogrosensis exerce grande atividade contra as bactérias Klebsiella pneumoniae e Proteus mirabilis (Gram-negativas).

Os pesquisadores relatam que por intermédio de análises estruturais in silico desta molécula demonstrou que a ação da enzima era devido a três peptídeos que eram importantes para a atividade da enzima. Esta molécula mesmo depois de passar pelo processo da síntese continuava exercendo atividade contra as mesmas bactérias. Esses peptídeos provenientes dessa enzima são candidatos fortes a produtos biotecnológicos, isto devido, ao seu baixo custo e por ser um peptídeo pequeno facilita dessa forma o processo da síntese (Okubo et al., 2012).

Algumas pesquisas tem se mostrado eficiente quando o assunto é a investigação de novas funções dessas biomoléculas: a "promiscuidade" ou "mistura" tem sido uma tática fundamental na evolução do peptídeo, provocando a disseminação de novas e múltiplas funções que podem ser integradas com uma única estrutura resultando na evolução de proteínas com novas funções. Com isso, essa "promiscuidade" ou "mistura" protéica é uma concorrente atrativa a ser 
adicionada ao complexo de defesa sendo usado por organismos superiores, para combater e/ou controlar patógenos e pragas vegetais (Franco, 2011; Silva et al., 2011).

Ainda que a principal função dos PAMs seja a sua "ação" para extinguir ou inibir o crescimento de microorganismos, muitos estudos têm mostrado que a ação dos PAMs não é restrita ao seu efeito antibacteriano, ou como efetores da resposta imune inata, mas também possuem atividade na sua ação antiviral (Wang et al., 2010). Alguns PAMs exibem efeito hemolítico contra eritrócitos humanos e outros ainda podem apresentar atividade inseticida ou serem potentes contra células cancerígenas (Hancock et al., 2006; Lai \& Gallo, 2009; Nguyen et al., 2011). A tabela 2 apresentada a seguir mostra a classificação de PAMs a partir de algumas variáveis importantes.

Alguns pesquisadores relatam ainda a atividade imunomodulatória de PAMs como, por exemplo, em hepicidina que é um peptídeo antimicrobiano produzido em resposta a estímulos inflamatórios e sobrecarga de ferro no organismo. A hepicidina ainda é amplamente distribuída nos tecidos sendo sintetizada no osso do peixe, desempenhando atividade na imunidade inata contra bactérias patogênicas (OteroGonzalez et al.,2010). A ação imunomodulatória pode ser vista, por exemplo, em crustinas que são peptídeos antimicrobianos extraídos a partir do camarão Litopenaeus vannamei (Otero-Gonzalez et al., 2010). A importância dos imunomoduladores no controle e prevenção de infecções é algo bastante relevante, se considerarmos 0 interesse freqüente acerca das moléculas bioativas de origem marinha designada como agentes imunomoduladores em sistemas "alternativos" na medicina (Chandraraj et al., 2010). 
Avaliação dos efeitos citotóxicos e antiproliferativos da secreção cutânea e de peptídeos

bioativos do anuro Physalaemus nattereri (Steindachner, 1863)

Tabela 2. Classificação dos antimicrobianos em função de diversas variáveis.

\begin{tabular}{|c|c|c|}
\hline VARIÁVEL & CLASSIFICAÇ̃̃O & EXEMPLO \\
\hline \multirow{4}{*}{$\begin{array}{l}\text { Microrganismos } \\
\text { suscetiveis }\end{array}$} & Antibacterianos & Beta-lactâmico \\
\hline & Antifúngicos & Griseofulvina \\
\hline & Antivirais & Aciclovir \\
\hline & Antiparasitários & Pirimetamina \\
\hline \multirow{2}{*}{$\begin{array}{c}\text { Origem do } \\
\text { antimicrobiano }\end{array}$} & Antibióticos: produzidos por microorganismos & Aminoglicosídeo \\
\hline & Quimioterápicos: sintetizados em laboratório & Sulfonamidas \\
\hline \multirow[b]{2}{*}{$\begin{array}{c}\text { Atividade } \\
\text { antibacteriana }\end{array}$} & Bactericida: matam os microorganismos & Quinolona \\
\hline & $\begin{array}{l}\text { Bacteriostático: inibem o crescimento dos } \\
\text { microorganismos, sendo necessária a atuação do } \\
\text { sistema imunitário para eliminação do germe. }\end{array}$ & Macrolídeo \\
\hline \multirow{5}{*}{ Mecanismo de Ação } & Alteração de parede celular & Beta-lactâmico \\
\hline & Alteração de membrana citoplasmática & Anfotericina B \\
\hline & Interferência na replicação cromossômica & Antifungicos/antivirais \\
\hline & Inibição da síntese protéica & Aminoglicosídeo \\
\hline & Inibição metabólica & Sulfonamida \\
\hline \multirow{9}{*}{ Espectro de Ação } & Espectro para Gram-positivas (*) & Penicilina \\
\hline & Espectro para Gram-negativas (**) & Aminoglicosídeos \\
\hline & Amplo espectro & Cloranfenicol \\
\hline & Ativo sobre protozoários & Tetraciclina \\
\hline & Ativo sobre fungos & Nistatina \\
\hline & Ativo sobre espiroquetas & Eritromicina \\
\hline & Ativo sobre riquétsias, micoplasma e clamídias & Macrolideo \\
\hline & Ativo sobre micobactérias & Estreptomicina \\
\hline & Ativo sobre algas & Anfotericina B \\
\hline
\end{tabular}

Fonte: Guia dos antimicrobianos (Hospital das Clínicas de Goiânia, 2012).

(*) Bactéria Gram-positiva - possuem parede celular com uma única e espessa camada de peptideoglicanos. Quando este tipo bacteriano entra em contato com a coloração de Gram adquirem a cor púrpura ou azul quando fixada com cristal violeta.

$\left.{ }^{* *}\right)$ Bactéria Gram-negativa possuem parede celular mais delgada e apresentam uma segunda membrana lipídica, diferente da membrana plasmática. Quando em contato com a coloração Gram o lipídio da membrana mais externa é dissolvido no álcool e libera o primeiro corante, o cristal violeta.

Dessa forma, os agentes antimicrobianos são essenciais para a saúde e bemestar humano e animal, e a resistência a esses agentes é uma preocupação de saúde pública mundial (WHO, 2005). Sendo assim, a seletiva pressão exercida por patógenos microbianos em rápida evolução na liderança de ambiente estimula e a diversificação de PAMs em anuros (Wang et al., 2007). 
Com base na seqüência de aminoácidos, os PAMs (peptídeos antimicrobianos) vão se tornando cada vez mais específicos. Como exemplo, dos avanços de pesquisas acerca desses peptídeos podemos classificar a família Ranidae onde foram descobertos 14 novas famílias de peptídeos sendo nomeadamente de Brevinin-1, Brevinin-2, Esculentin-1, Esculentin-2, Japonicin-1, Japonicin-2, Nigrocin-2, Palustrin-1, Palustrin-2, Ranacyclin, Ranalexin, Ranateurin1, Ranateurin-2, e Temporin (Colon J.M., 2008). Desde sua descoberta, centenas de outros PAMs foram isolados da pele desses anuros.

\subsection{Resistência bacteriana e bactérias patogênicas}

$\mathrm{Na}$ definição sobre resistência bacteriana são relevantes os aspectos clínicos da utilização de antibióticos. A partir de dados laboratoriais os testes do antibiótico contra a bactéria, resultando em resistência, mostra que o microorganismo tem a capacidade de crescer in vitro na presença da droga, e levando em consideração a concentração da mesma no sangue (Reddy et al., 2004).

A resistência bacteriana pode ser intrínseca (natural) ou ainda adquirida. A intrínseca é dada a uma característica da espécie bacteriana, que "naturalmente" cria uma barreira de permeabilidade contra o antibiótico, como por exemplo, a presença de membrana externa nas bactérias Gram-negativas. Um exemplo da resistência intrínseca são os microorganismos do gênero Klebsiella que são resistente à ampicilina, amoxicilina, carbenicilina e ticarcilina e o $S$. aureus resistente a todos os $\beta$-lactâmicos. Já a resistência bacteriana adquirida é dada a uma característica da espécie resultante da alteração do material genético existente ou a aquisição de novo material genético de outra fonte. Ela pode ser revelada em apenas algumas cepas de uma mesma espécie bacteriana resultando da mutação ou desrepressão (na inativação do gene repressor, o gene operador torna-se ativo novamente, fazendo com que se manifeste a resistência não só à droga em uso, mas também a outros antibióticos). Como foi abordado anteriormente. Esta resistência já foi descrita em praticamente todas as espécies de bactérias, conhecendo-se detalhes dos mecanismos de aquisição e os mecanismos moleculares da manifestação da resistência (Okubo et al., 2012). 
Mesmo que a resistência adquirida dos peptídeos antimicrobianos (PAMs) seja menos provável de acontecer em comparação com as terapias antimicrobianas tradicionais, a resistência contra os peptídeos acontece por meio da evolução de algumas bactérias Gram-negativas (descrito a seguir) que empregam enzimas celulares com a finalidade de alterar bioquimicamente e diminuir a carga líquida negativa de suas membranas celulares (Peters et al., 2010). Um outro tipo de resistência consiste na degradação dos peptídeos por atividade proteolítica, que pode ser exemplificado pela ação da bactéria Proteus mirabilis contra o peptídeo antimicrobiano humano LL-37, da família das catelicidinas (Visto na sessão anterior).

A resistência pode acontecer também pela formação de um "escudo" na superfície da célula bacteriana por meio da cápsula de polissacarídeo (Figura 2a). Nos trabalhos desenvolvidos por (Spinosa et al., 2007), foi visto que cepas de Neisseria meningitidis que não tinham cápsula de polissacarídeo foram mais suscetíveis aos efeitos antimicrobianos de LL-37 e de $\alpha$ e $\beta$-defensinas humanas (Figura $2 b$ ). Outra maneira de se ter a resistência bacteriana contra peptídeos é fundamentada na capacidade que algumas bactérias têm na modificação da sua membrana na qual o lipídeo A e porções de lipopolissacarídeo presentes na membrana externa bacteriana podem ser alterados de forma covalente em bactérias tipo Gram-negativas (Figura 2c). Outras bactérias têm a capacidade de enviar peptídeos tanto para dentro como para fora da célula bacteriana. Os peptídeos que estão sendo enviados para dentro da célula são degradados pela ação de enzimas proteolíticas e os peptídeos exportados para o meio extracelular, não são ativos contra a bactéria (Figura 2d). Algumas bactérias exercem supressão da expressão PAMs observadas nas exotoxinas de Vibrio cholerae que produzem o efeito da supressão da expressão de LL-37 pela célula hospedeira (Figura 2e) (Chakraborty et al., 2008). 
(a)

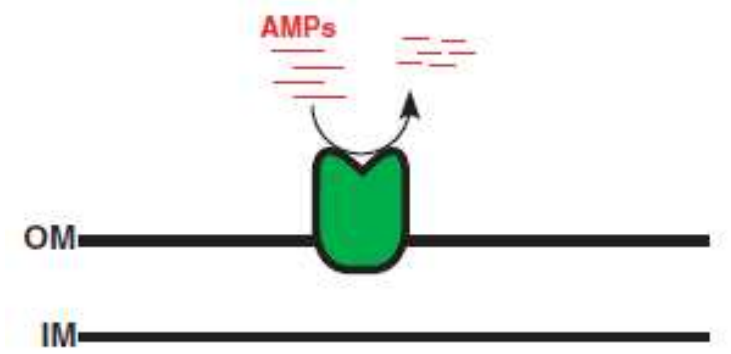

(c)

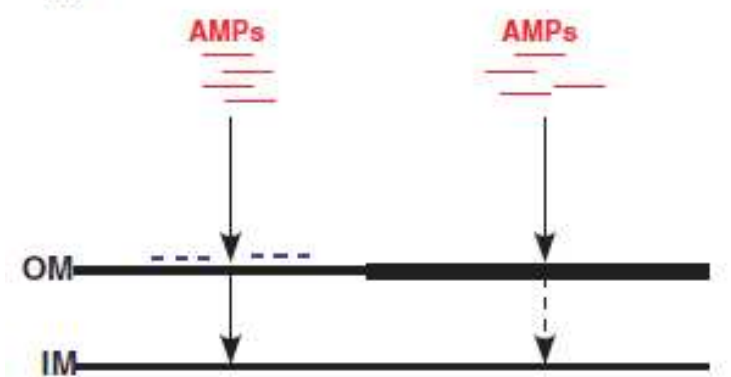

(e)

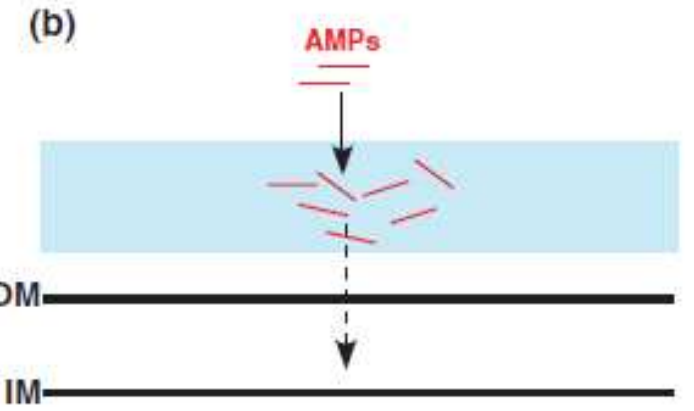

(d)

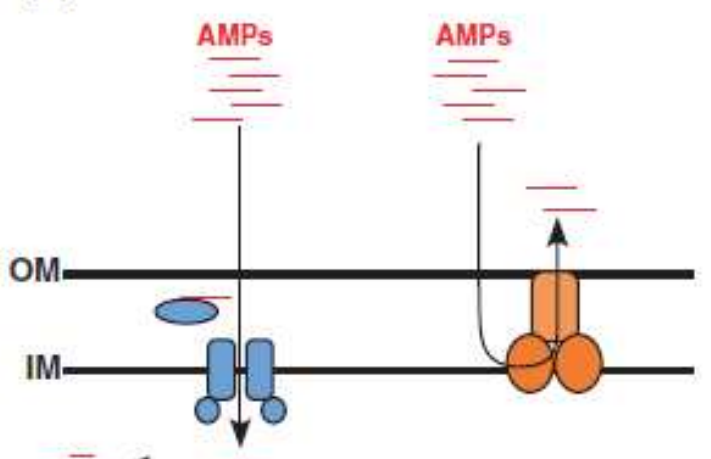

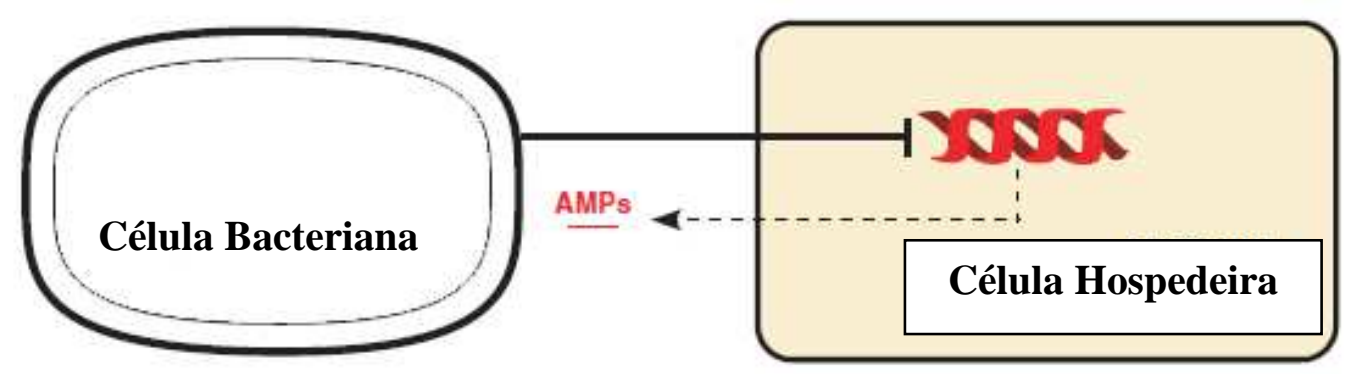

Figura 2. Esquema dos mecanismos de resistência contra peptídeos antimicrobianos (PAMs) desenvolvidos por bactérias Gram-negativas. (a) Degradação dos peptídeos por enzimas proteolíticas localizadas na membrana externa (ME). (b) "Escudos" formados por cápsulas de polissacarídeo. (c) Modificações na ME que impedem ou inibem o contato do peptídeo com a membrana interna (MI). (d) Bombas que enviam os peptídeos para dentro ou para fora da bactéria. (e) Supressão da expressão gênica de peptídeos antimicrobianos pela célula hospedeira. Fonte: Retirada de (Gruenheid e Le Moual, 2012).

Outro aspecto importante que se deve compreender é que a resistência bacteriana a antibióticos é um fenômeno natural e anterior à pressão seletiva atual causada pelo uso clínico de antibióticos, porém o seu uso inadequado tem exercido influencia na seleção de genes de resistência previamente existentes. (D'costa et al., 2011; Schmieder \& Edwards, 2012). 
Já a resistência bacteriana aos antimicrobianos é fundamentada em nível genético, indicando que mudanças na composição genética das bactérias previamente suscetíveis ocorrem por dois processos: mutações, que ocorrem no germe durante seu processo reprodutivo e resultam de erros de cópia na seqüência de bases que formam o DNA cromossômico, quanto por introdução de genes, consistindo na resistência transferível. Esta resistência faz-se através dos mecanismos de transdução, transformação e conjugação e, freqüentemente, envolve genes situados em plasmídios e transposons (Jolivet-gougeon et al., 2011). De forma simples, podemos dizer que esta relacionado à existência de genes contidos no microrganismo que codificam diferentes mecanismos bioquímicos que impedem a ação das drogas.

Em vários microrganismos o fenômeno da resistência é natural. Onde a resistência é tida como específica se for "efetora" contra um determinado antibiótico naqueles microrganismos produtores desta mesma substância. Assim, por exemplo, - Streptomyces erythraeus, produtor da eritromicina, é naturalmente resistente a este antibiótico por possuir uma estratégia de sobrevivência que impede sua autointoxicação. Esta estratégia consiste em possuir uma subunidade $50 \mathrm{~S}$ ribossomal à qual a eritromicina não se fixa, não exercendo, dessa forma, ação (Cundliffe $E$. 1984; Demain Al. 1974).

No desenvolvimento da resistência bacteriana é necessário que pelo menos dois elementos sejam combinados: um antibiótico capaz de inibir a maioria das bactérias presentes em uma colônia e uma colônia heterogênea de bactérias, onde pelo menos uma destas bactérias carregue a parte genética que seja capaz de expressar resistência ao antibiótico. A lista de bactérias e fungos que desenvolveram resistência a antibióticos é extensa e relativamente preocupante, satisfazendo mais de $70 \%$ das bactérias que causam infecção. Muitos patógenos bacterianos e fúngicos desenvolveram resistência a todos os antimicrobianos conhecidos e desde meados de 1960 cepas resistentes são observadas ( $S$. aureus) e outras mais recentes em 1990 como o fungo Candida albicans. Estas resistências e outras iniciadas ao longo de 60 anos atrás podem ser observadas na Figura 3. 


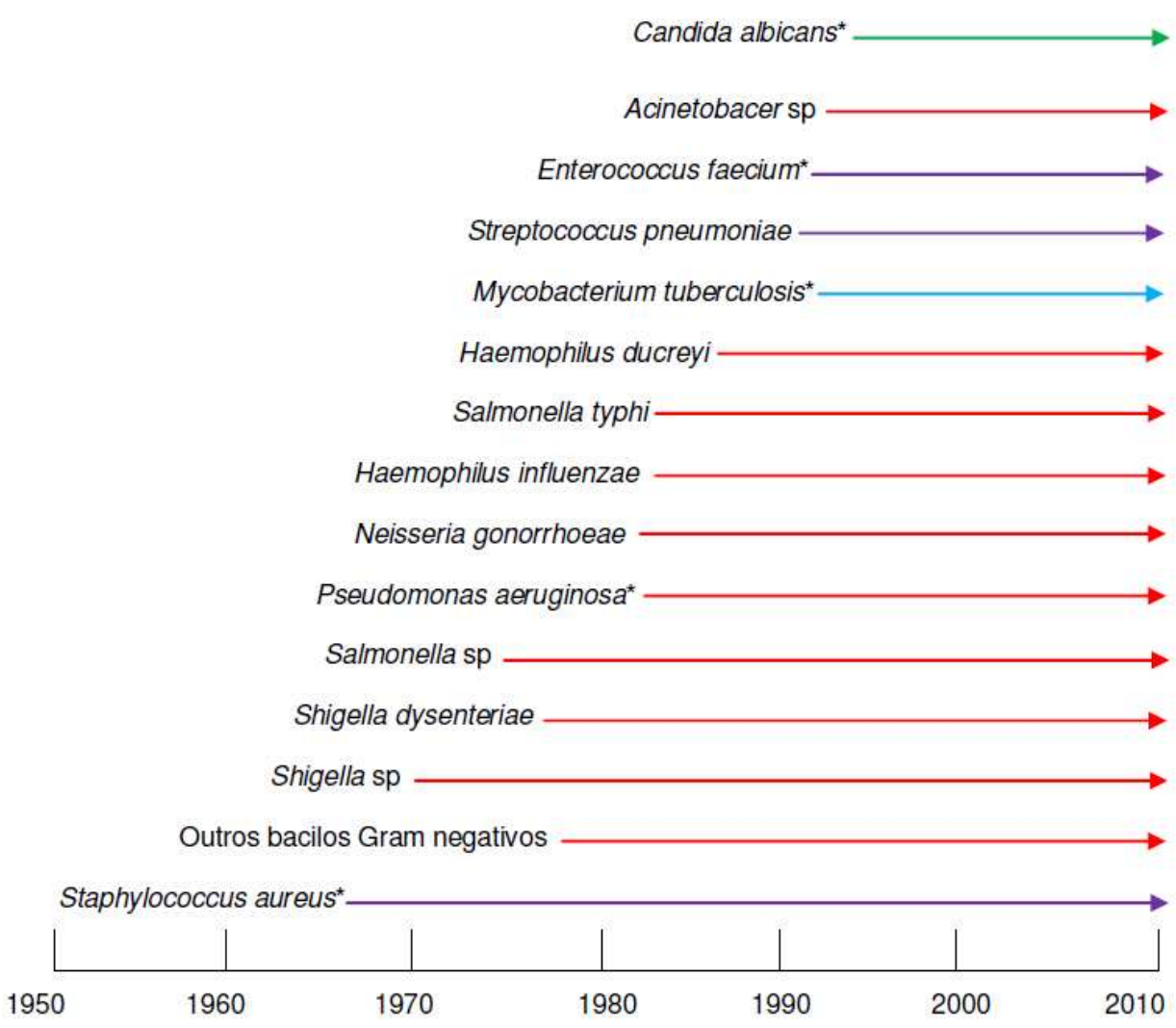

Figura. 3. Resistência aos antibióticos convencionais em alguns patógenos de humanos. Asteriscos indicam que algumas linhagens destes patógenos atualmente não podem ser tratadas com os fármacos existentes. Legenda: (Verde) Fungos; (Vermelho) Gram-negativo; (Roxo) Grampositivo. (Azul) Gram positivo/ resistente. Fonte: Mandigan et al., (2010).

\subsubsection{Breve histórico da resistência bacteriana}

Dessa forma, o conhecimento acerca da resistência a agentes físicos e químicos entre os microrganismos data do início da era microbiana. Com a introdução das primeiras substâncias químicas com finalidade quimioterápica específica, Ehrlich e seus colaboradores Franke e Roehl apud (Albert A. 1968), em 1905, descobriram o fenômeno da resistência às drogas, ao observarem que em culturas de tripanossomas africanos tratados com arsênico ou com determinados corantes existia a sobrevivência de alguns exemplares da mesma população microbiana. Estes autores descreveram que infecções por tripanossomas tratadas com concentrações baixas de arsênico recaíam e relataram que um novo tratamento falhava porque os tripanossomas haviam desenvolvido resistência às drogas e que esta resistência passava a ser hereditária. O uso clínico de sulfonamidas, e da 
penicilina, em 1941, levou à constatação de que a resistência bacteriana aos agentes antimicrobianos podia ser uma característica natural das espécies de bactérias ou ser adquirida por cepas individuais dentro de uma população sensível.

Fleming (Fleming A. 1980) ao descobrir a penicilina, foi o primeiro observador da resistência natural de microrganismos aos antibióticos, descrevendo que bactérias do grupo coli tifóide e a Pseudomonas aeruginosa (Bacillus pyocyaneus) não eram inibidas pelo antibiótico. A causa desta resistência natural foi, pouco depois, descoberta por Abraham e Chain (Nature, 1940), na década de 40, um ano antes da primeira publicação sobre o uso clínico da penicilina, demonstraram em extratos de E. coli uma enzima capaz de destruir a ação da penicilina, a qual denominaram penicilinase. A difusão do uso clínico da penicilina trouxe ao conhecimento o fato de que entre microrganismos sensíveis ao antibiótico haviam exemplares resistentes, sendo verificado em 1944, que Staphylococcus aureus isolados de material clínico mostravam-se resistentes à penicilina devido à produção de penicilinase. Em 1946, nos Estados Unidos, cerca de 5\% de estafilococos isolados de pacientes ou portadores eram resistentes à penicilina. Em 1949, a resistência era notada em $29 \%$ dos germes isolados em hospitais norte-americanos; em 1950 atingia $50 \%$ e na década de 60 , o crescimento era de cerca de $80 \%$. No Brasil, atualmente, o índice é de $80 \%$ dos S. aureus isolados de pacientes hospitalizados e cerca de $70 \%$ dos isolados de pacientes da comunidade apresentam resistência às penicilinas naturais e, por extensão, à ampicilina e amoxicilina. Atualmente, a resistência bacteriana adquirida é descrita em praticamente todas as espécies de bactérias, conhecendo-se os detalhes dos mecanismos de aquisição de resistência e os mecanismos moleculares da manifestação da resistência (Jacoby GA. 1998; Jacoby GA, \& Archer GL. 1991). Dentre os microrganismos que sofreram grandes modificações na sensibilidade aos antimicrobianos ao decorrer dos anos, destacam-se estafilococos, as enterobactérias, Pseudomonas aeruginosa, o Acinetobacter baumannii e, mais recentemente, os hemófilos, gonococos, enterococos e pneumococos.

Nos dias atuais as grandes preocupações na utilização de antibióticos para o tratamento de infecções consistem no alto custo para a produção do fármaco no intuito de ser utilizado por pouco tempo e algumas vezes por poucas pessoas. O mercado onde estes fármacos têm tendência a ser de baixo custo; e o 
desenvolvimento de resistência que pode ocorrer também com peptídeos antimicrobianos que servem como alternativa ao uso desses medicamentos. Ainda podemos relatar que, em muitos casos, estas bactérias e fungos podem desenvolver resistência simultânea de duas ou mais classes de antibióticos o que faz com que o tratamento de infecções causadas por estes microorganismos se torne extremamente difícil (Alanis, 2005).

Diante dessa problemática da indústria farmacêutica e como a prevalência de bactérias resistentes aos antibióticos continua a crescer, tornou-se inevitável a busca para o desenvolvimento de novas alternativas e/ou de antibióticos melhores e com baixa toxicidade. Espera-se que tais moléculas sejam capazes de eliminar um microorganismo vagamente relacionado aos seres humanos que tem desenvolvido grande resistência aos antibióticos convencionais abrandando assim a situação que se estende sobre os sistemas de saúde em todo o mundo (Fischbach \& Walsh, 2009). Essa problemática atualmente é motivo de grande preocupação entre os cientistas, microbiologistas e médicos. A resistência entre as bactérias vêm se tornando um problema freqüente na terapêutica anti- infecciosa.

\subsubsection{Bactérias patogênicas}

De maneira geral, as bactérias são seres procariontes, não apresentam material genético protegido por membrana, desta forma, não apresentam núcleo. As bactérias, por sua enorme distribuição e pelo tempo de vivência, apresentam diversas formas de nutrição, advindas da evolução de sua espécie. Dessa maneira, elas podem ser classificadas como autótrofas. Neste caso, existem bactérias que possuem a capacidade fotossintetizante, e as quimiossintetizante. As heterótrofas, podendo ser: saprófagas ou parasitas. As bactérias são classificadas de acordo com a coloração que possuem, dessa forma, podem apresentar-se com característica bacilos Gram-negativos, não esporulantes, com motilidade variável, oxidase negativa, e de fácil crescimento em meios básicos, meios ricos e meios seletivos. A maioria é encontrada no trato gastrointestinal de humanos, assim como outros animais, na água, solo e vegetais (Levy, 2004).

A parede celular das bactérias Gram-negativas pode ser formada por três estruturas: uma membrana externa (ME) constituída por uma bicamada de 
fosfolipídios, onde estão ancorados os lipopolissacarídeos (LPS); uma membrana interna (MI), também uma bicamada de fosfolipídios; e separando as ME e Ml fica o espaço Peri plasmático e nele a camada de peptideoglicanos (Jones, 1988). Vários grupos de proteínas estão associados a essas membranas, como as porinas que associadas a ME permitem a entrada de nutrientes na célula; as lipoproteínas, associadas a ME por uma calda lipídica na subunidade N-terminal; as proteínas integrais, que atravessam a ME em várias regiões; as proteínas periplasmáticas; e as proteínas associadas à Ml, envolvidas com ligação a ATP, transporte de íons, e pequenas moléculas.

As bactérias Gram-negativas produzem uma variedade de polissacarídeos. Dentre esses, o lipopolissacarídeo, os exopolissacarídeos e os polissacarídeos capsulares são particularmente importantes para o reconhecimento imune do hospedeiro. Entretanto, eles diferem quanto à localização na parede celular bacteriana e função. Os lipopolissacarídeos são ancorados na membrana externa das bactérias através de sua porção lipídica e atuam como moléculas de reconhecimento padrão associadas ao patógeno, estimulando a resposta do hospedeiro. Os exopolissacarídeos normalmente são encontrados livres no meio extracelular e podem formar barreiras físicas (biofilmes e estruturas capsulares), as quais favorecem a evasão da resposta imune do hospedeiro. Já em relação às bactérias Gram-positivas apresentam composição singular em sua parede celular. Além da ausência da ME, a camada de peptideoglicanos forma um arcabouço espesso composto por uma alternância de $\mathrm{N}$-acetil-glicosamina e ácido $\mathrm{N}$ acetilmurâmico.

As bactérias vêm sendo relatadas como as principais responsáveis por vários tipos de infecção (Levy, 2004). Entretanto, os índices, por exemplo, acerca de infecções hospitalares são difíceis de calcular, principalmente por falta de informações provenientes dos sistemas de saúde de todo o mundo (Fischbach; \& Walsh, 2009). Dados europeus relatam que, considerando uma pesquisa realizada em unidades de atendimento no ano 2000, os fungos foram associados a aproximadamente $10 \%$ dos casos de infecções hospitalares, as viroses cerca de $22 \%$ dos casos, e as bactérias a $68 \%$ dos casos. Os patógenos que lideram o ranking das infecções hospitalares estão descritos na tabela 2. As bactérias Gramnegativas é considerada a maior e mais heterogênea família de bactérias estando 
diretamente envolvida nestas infecções, sendo identificadas em $95 \%$ das amostras de casos clínicos de infecções hospitalares bacterianas (Levy, 2004).

Dentre essas ocorrências, podemos citar as seguintes bactérias gramnegativas: E. coli, Staphylococcus, Proteus e Klebsiella e o Enterococcus faecalis, considerando a frequência, tem sido a principal causa de infecções do trato urinário (Lopes \& Tavares, 2005); enquanto Klebsiella sp. e Enterobacter sp. de pneumonias e infecções intestinais; e Salmonella sp. de gastroenterites. Entretanto, todas as bactérias gram-negativas têm sido implicadas em infecções sanguíneas, peritonites, colites e outras infecções intra-abdominais (Levy, 2004; Hujer et al., 2006). Como por exemplo, as infecções do trato urinário que estão entre as doenças infecciosas mais comuns na clínica médica, com ocorrência em crianças, adultos jovens e mulheres sexualmente ativas, sendo apenas menos freqüente que as do trato respiratório. Dentre as principais bactérias isoladas em casos de infecções pulmonares são Klebsiella sp., E. coli e Enterobacter sp.

\subsection{Câncer}

O câncer é uma das principais causas de morte no mundo. Estimativas apontam que cerca de 12,7 milhões de novos casos e 7,6 milhões de mortes por câncer ocorreram no mundo em 2008 (Globocam, 2008). Considerando que o número de casos da doença vem aumentando a cada ano, previsões feitas para o ano de 2030 sugerem o aparecimento de 20 a 26 milhões de novos casos e 13 a 17 milhões de mortes (WHO, 2011).

As figuras 4 e 5 respectivamente, mostram os tipos de câncer de maior incidência no mundo. Percebe-se que apesar dos dados serem referentes aos anos de 2008 e 2010, o que continua chamando atenção é a similaridade em relação ao câncer de mama que independete do ano de estatística está em primeiro lugar no mundo (INCA). Estudos epidemiológicos durante as últimas décadas têm demonstrado que a incidência e mortalidade por câncer variam significativamente entre as diferentes regiões do mundo (Stewart \& Coates, 2005; Kelloff et al., 2000). Apesar dos recentes avanços na terapia do câncer, a doença vem sendo uma das principais causas de morbidade e mortalidade no mundo. 
O câncer é o nome dado a um conjunto de mais de 100 doenças que têm em comum o crescimento desordenado (maligno) de células que invadem os tecidos e órgãos, podendo espalhar-se (metástase) para outras regiões do corpo. Dividindo-se rapidamente, estas células tendem a ser muito agressivas e incontroláveis, determinando a formação de tumores (acúmulo de células cancerosas) ou neoplasias malignas (INCA 2015). Por outro lado, um tumor benigno significa simplesmente uma massa localizada de células que se multiplicam vagarosamente e se assemelham ao seu tecido original, raramente constituindo um risco de vida (Almeida et al., 2005).

Tabela 3. Agentes infecciosos mais comumente encontratos em humanos e seus locais de isolamento.

\begin{tabular}{|c|c|}
\hline Patógeno & $\begin{array}{l}\text { Regiões comuns de isolamento do } \\
\text { patógeno }\end{array}$ \\
\hline \multicolumn{2}{|c|}{ Bactérias Gram-negativas } \\
\hline E. coli & Trato urinário, feridas cirúrgicas, sangue. \\
\hline Pseudomonas sp. & $\begin{array}{l}\text { Trato urinário, trato respiratório, } \\
\text { queimaduras. }\end{array}$ \\
\hline Proteus sp. & Trato urinário, feridas cirúrgicas. \\
\hline Klebsiella sp. & $\begin{array}{l}\text { Trato urinário, trato respiratório, feridas } \\
\text { cirúrgicas. }\end{array}$ \\
\hline Enterobacter sp. & $\begin{array}{l}\text { Trato urinário, trato respiratório, feridas } \\
\text { cirúrgicas. }\end{array}$ \\
\hline \multicolumn{2}{|c|}{ Bactérias Gram-positivas } \\
\hline Streptococcus sp. & $\begin{array}{l}\text { Trato urinário, trato respiratório, feridas } \\
\text { cirúrgicas. }\end{array}$ \\
\hline S. aureus & Pele, feridas cirúrgicas, sangue. \\
\hline Staphyloccus epidermidis & Pele, feridas cirúrgicas, sangue. \\
\hline \multicolumn{2}{|c|}{ Fungos } \\
\hline Cândida albicans & Trato urinário, sangue. \\
\hline Cryptococcus neoformans & Trato urinário, sangue. \\
\hline
\end{tabular}

Fonte: (Levy, 2004; Maria-Neto, 2011). 
É importante ressaltar que, o câncer é caracterizado por desordens celulares desencadeadas por mutações no material genético causadas por fatores genéticos, epigenéticos e/ou ambientais. Em geral, mecanismos de morte celular são acionados em células com alterações irreparáveis no DNA, para prevenir a propagação de mutações ao longo das gerações. No entanto, células tumorais apresentam alterações nesses mecanismos de regulação resultando no aumento da proliferação celular e possível invasão dessas células para outros tecidos do corpo (Hanahan \& Weinberg, 2011). O câncer é uma patologia que ocorre em diversos tipos celulares e, devido às alterações genéticas e epigenéticas terminam por desencadear outras patologias, tornando a cura um desafio para a medicina (Weinberg, 2006).
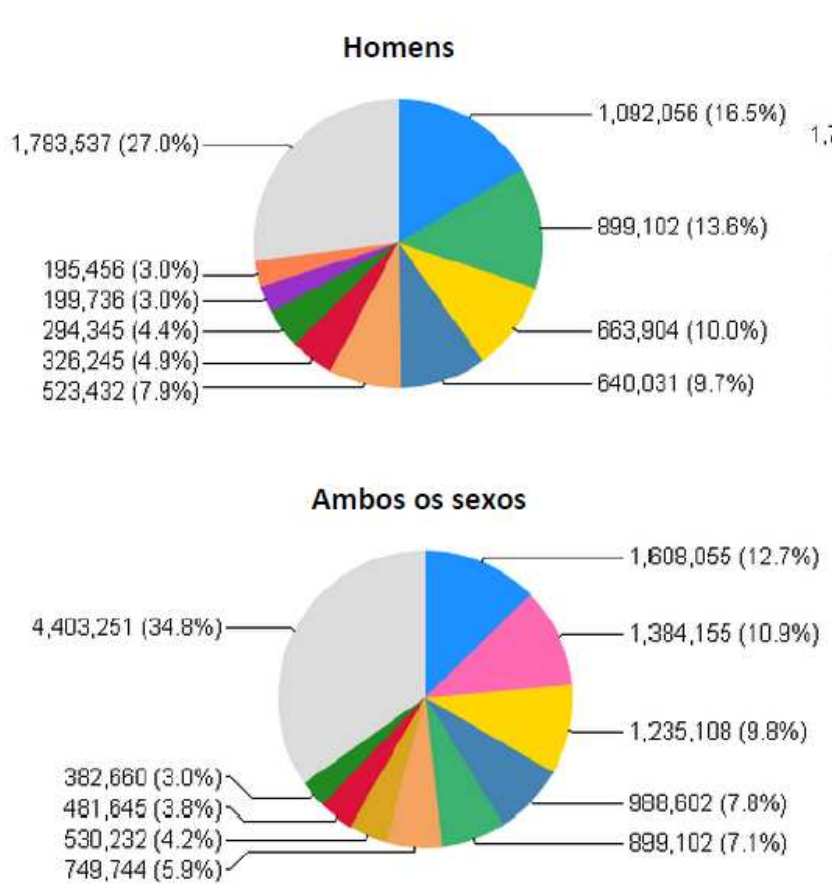

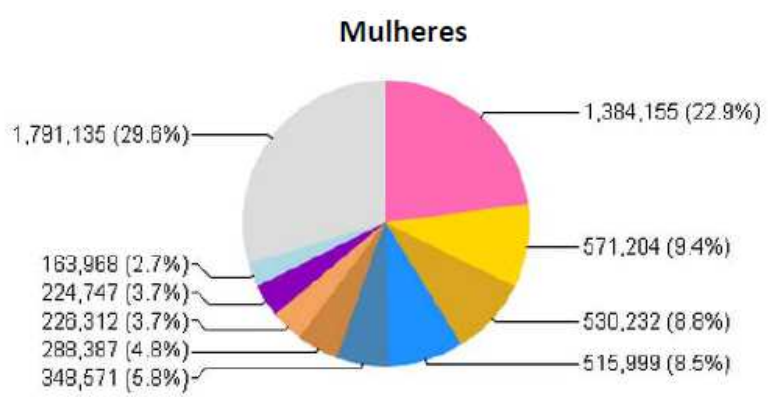
Legenda
Pulmão
Mama
Colorretal
Estômago
Próstata
Fígado
Colo do útero
Esôfago
Bexiga
Outros

Figura 4. Taxas de incidência de novos casos de câncer no mundo. Adaptado de GLOBOCAM 2008. (Dados de 2008). 


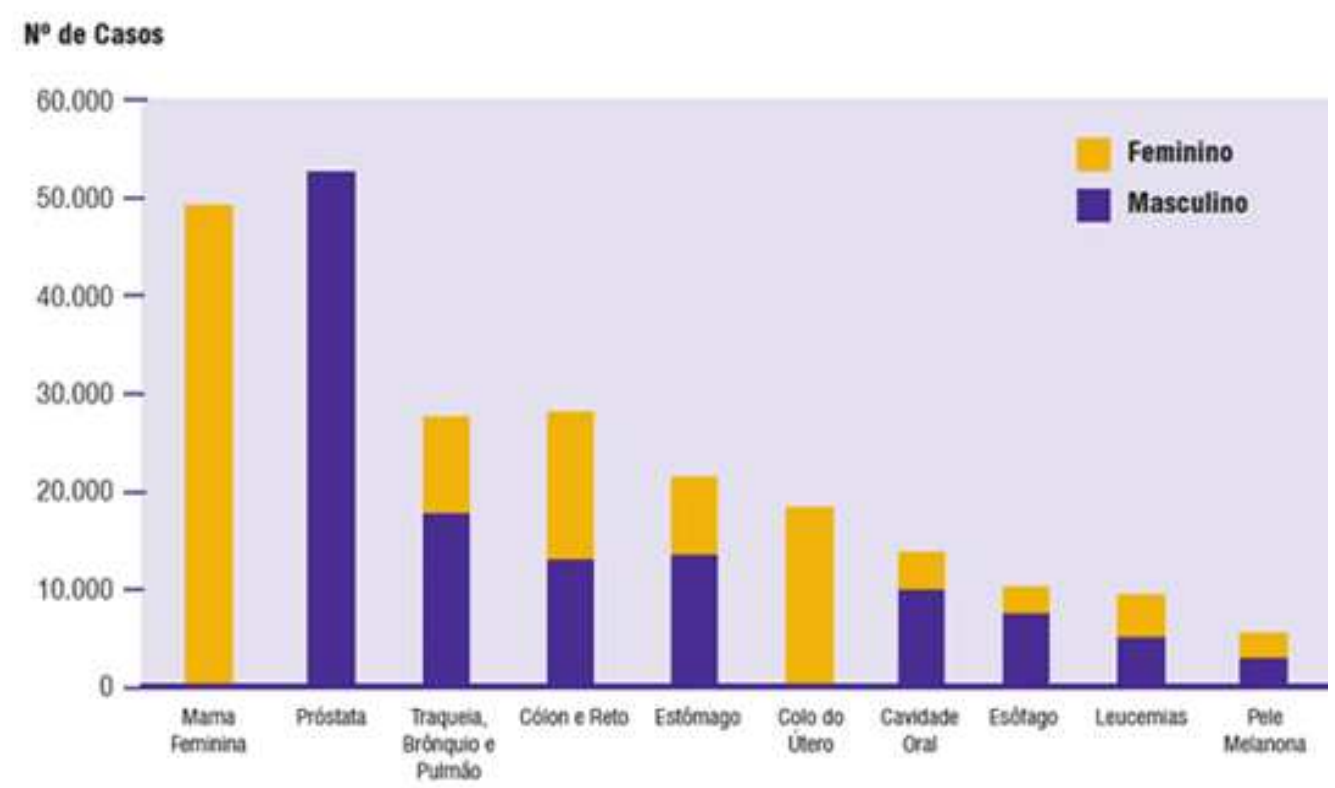

Figura 5. Tipos de câncer de maior incidência no mundo. Fonte: Instituto Nacional do câncer (INCA). Dados ano 2010.

Os diferentes tipos de câncer correspondem aos vários tipos de células do corpo. Por exemplo, existem diversos tipos de câncer de pele porque a pele é formada de mais de um tipo de célula. Se o câncer tem início em tecidos epiteliais, como pele ou mucosas, ele é denominado carcinoma. Se começa em tecidos conjuntivos, como osso, músculo ou cartilagem, é chamado de sarcoma. Outras características que diferenciam os diversos tipos de câncer entre si são a velocidade de multiplicação das células e a capacidade de invadir tecidos e órgãos vizinhos ou distantes (metástases). No tratamento do câncer existem diferentes estratégias para tratá-lo, dentre essas, podemos citar: cirurgia especifica para casos de tumores sólidos, Radioterapia, que geralmente é indicada no processo pós-cirúrgico, e a quimioterapia, que ainda é o tratamento de escolha para os casos mais graves (tumores generalizados). No entanto, os convencionais agentes quimioterápicos, que agem contra a alta proliferação células através da inibição da síntese de ácidos nucleicos, induzem indesejáveis efeitos colaterais (Almeida et al., 2005). A terapia ainda é complicada devido à resistência adquirida de tumores por quimioterápicos (Dennison et al., 2006;. Hoskin \& Ramamoorthy, 2008). Se considerarmos que a grande maioria dos fármacos existentes são antineoplásicos sendo agentes antiproliferativos que interferem no ciclo celular, uma vez que as células tumorais multiplicam-se mais rapidamente que a maioria das normais. Comumente, quando 
se administra um fármaco antineoplásico, apenas uma pequena fração da dose reage com os sítios de ação. A maior parte é distribuída aos órgãos sadios, provocando-Ihes toxicidade (Anchiêta Júnior, 2012).

Ainda considerando que a quimioterapia atualmente é um dos principais modos de tratar o câncer, sua efetividade é limitada pelo desenvolvimento de resistência pelas células tumorais. Essa resistência pode ser intrínseca, quando antes de receber a quimioterapia, existem fatores de mediação ou resistência da maioria das células, o que torna a quimioterapia ineficaz, ou adquirida que se desenvolve durante o tratamento de um tumor que inicialmente era sensível, cujas células podem sofrer mutações, bem como ter outras respostas adaptativas, como aumento da expressão do alvo terapêutico ou ativação de vias de sinalização alternativas (Masui et al., 2013). De acordo com a literatura, sabe-se que drogas antitumorais desenvolvidas a partir de recursos naturais são pesquisadas em todo o mundo. (Sciani et al., 2013). Venenos de animais e toxinas são recursos potentes e ferramentas terapêuticas conhecidas pelo homem há séculos através dos conhecimentos popular e tradicional. O uso da secreção cutânea de anfíbios tem sido documentado em várias culturas e folclores em várias regiões do mundo. $\mathrm{O}$ conhecimento tradicional tem sido envolvido no conceito de que a pele dos anfíbios pode ser um tesouro de compostos biologicamente ativos. Buscas por secreções tóxicas ou nocivas e a presença de aminas biogênicas, peptídeos, bufadienolídeos, tetrodotoxinas, alcaloides lipofílicos foram descritas há alguns anos. Desde então, investigações têm sido feitas, adicionando centenas de compostos a essa lista de substâncias ativas isoladas da pele de anfíbios (Sciani et al., 2013).

\subsubsection{Desencadeamento do câncer}

As causas do câncer são variadas, podendo ser externas ou internas ao organismo, estando ambas inter-relacionadas. As causas externas relacionam-se ao meio ambiente e aos hábitos ou costumes próprios de um ambiente social e cultural. As causas internas são derivadas de oncogenes hereditários. Os outros cânceres envolvem alterações ou danos no material genético das células que são acumulados ao longo do tempo (AICR, 2007). Devido a uma série de alterações genéticas e epigenéticas, uma vasta combinação de mutações terminam por desencadear outras 
patologias, tornando a cura do câncer um importante desafio para a medicina (Weinberg et al., 2006). Cerca de 5 a 10\% dos cânceres são geneticamente prédeterminados e estão ligados à capacidade do organismo de se defender das agressões externas. Esses fatores causais podem interagir de várias formas, aumentando a probabilidade de transformações malignas nas células normais (Brandão et al., 2010). De todos os casos, $80 \%$ a $90 \%$ dos cânceres estão associados a fatores ambientais e/ou hábitos comportamentais (Irigaray et al., 2007). Alguns deles tem início com a exposição à fatores ambientais. A revolução industrial, em meados do século XIX, produziu e introduziu no meio ambiente inúmeras substâncias químicas fabricadas pelo homem sem o devido controle toxicológico. Alguns são bem conhecidos: o cigarro pode causar câncer de pulmão, e alguns vírus podem causar leucemia. Outros estão em estudo, como alguns componentes dos alimentos que ingerimos, e muitos são ainda completamente desconhecidos. Alguns produtos podem ainda atuar como poluentes tóxicos persistentes e contaminar ar, solo, água e alimentos. Além disso, eles podem atuar como agentes mutagênicos ou promotores de câncer (Irigaray et al., 2007). As mudanças provocadas no meio ambiente pelo próprio homem, os hábitos e o estilo de vida adotados pelas pessoas podem determinar diferentes tipos de câncer (AICR, 2007). Estudos mostram que o restante (5 a 10\%) dos cânceres são derivados de oncogenes hereditários (AICR 2007).

A exposição à radiação também contribui para o aumento das taxas de incidência do câncer e está relacionada não só com câncer de pele, mas a outros tipos de câncer, como de mama, pulmão, tireóide e do sistema hematológico $(\mathrm{NIH}$, 2011). As principais fontes de exposição para a população são a radiação solar e também radiações advindas de exames médicos, como raios- $X$ e tomografia computadorizada $(\mathrm{NIH}, 2011)$. Outro fator ambiental importante é a infecção causada por vírus e outros microorganismos.

Estimativas apontam que agentes infecciosos estão relacionados à aproximadamente $18 \%$ de todos os casos de câncer no mundo. Os principais agentes envolvidos são o vírus HPV, vírus da hepatite B ou C, vírus Epstein-Barr e parasitas associados à inflamações crônicas como a bactéria Helicobacter pylori (Thun et al., 2010). O envelhecimento traz mudanças nas células que aumentam a sua suscetibilidade à transformação maligna. Isso, somado ao fato de as células das 
pessoas idosas terem sido expostas por mais tempo aos diferentes fatores de risco para o câncer, explica em parte o porquê de o câncer ser mais freqüente nesses indivíduos. Os fatores de risco ambientais de câncer são denominados cancerígenos ou carcinógenos. Esses fatores atuam alterando a estrutura genética (DNA) das células. O surgimento do câncer depende da intensidade e duração da exposição das células a os agentes causadores de câncer (AICR, 2007).

Pesquisa na área da epidemiologia tem mostrado que hábitos comportamentais referentes à baixa freqüência na prática de exercícios físicos, elevado consumo de álcool e tabaco, alimentação com excesso de carne vermelha e gorduras, e sobrepeso/obesidade também contribuem para o aumento no número de casos de câncer. Esses hábitos não causam necessariamente mutações no DNA, mas podem atuar como agentes co-carcinogênicos, aumentando a predisposição fisiológica de um organismo à desenvolver a doença (Irigaray et al., 2007; Thun et al., 2010). No caso do consumo de tabaco, além de conter substâncias cocarcinogênicas, a fumaça contém centenas de substâncias mutagênicas (nitrosaminas, por exemplo). Sendo assim, esse hábito se destaca como um dos principais fatores de risco para o desenvolvimento de câncer tanto para o fumante ativo quanto para o fumante passivo (Irigaray et al., 2007; NIH, 2011).

O panorama da distribuição global do câncer têm mostrado alterações com relação às regiões de maior incidência (Figura 6). Previsões apontam que no ano de 2050, mais de $60 \%$ de todos os casos de câncer no mundo ocorrerão em países em desenvolvimento e subdesenvolvidos (Thun et al., 2010). Essa estimativa representa não só um impacto na saúde da população, mas também na economia desses países, uma vez que muitos deles não poderão financiar aumentos excessivos nos gastos para o tratamento dessa doença (Thun et al., 2010). 


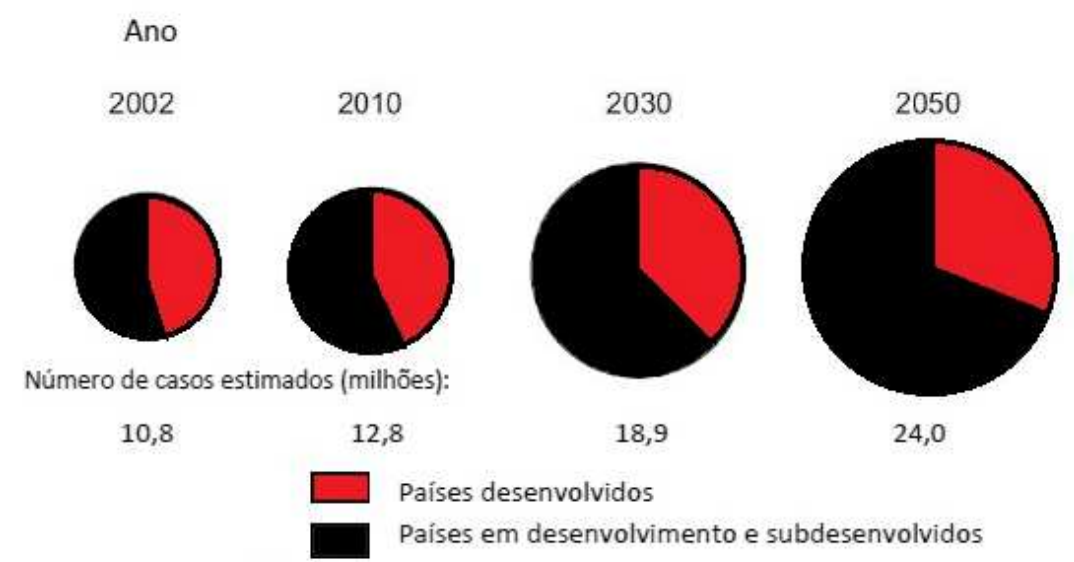

Figura 6. Distribuição dos casos de câncer no mundo por nível de desenvolvimento econômico. Adaptado de Thun et al., 2010.

\subsubsection{Desenvolvimento dos estágios do câncer}

Em geral, o desenvolvimento do câncer ocorre lentamente, podendo formar apenas um tumor, após muitos anos, à exposição ao agente carcinogênico. Esse processo é dividido em três estágios principais: a iniciação, a promoção e a progressão (Figura 7). No estágio de iniciação, as células apresentam alterações genéticas em decorrência da exposição ao agente carcinogênico; no entanto, ainda não é possível identificar o tumor clinicamente. No estágio de promoção, a célula afetada inicia, lentamente, o processo de transformação maligna caracterizado pela expressão de oncogenes. Por fim, o estágio de progressão caracteriza-se pela proliferação descontrolada e irreversível das células, formando uma massa tumoral no local. Nesse último estágio, algumas células podem entrar em metástase, ou seja, invadir a corrente sanguínea e se instalar em outros tecidos do organismo (Brentani et al., 2003). 


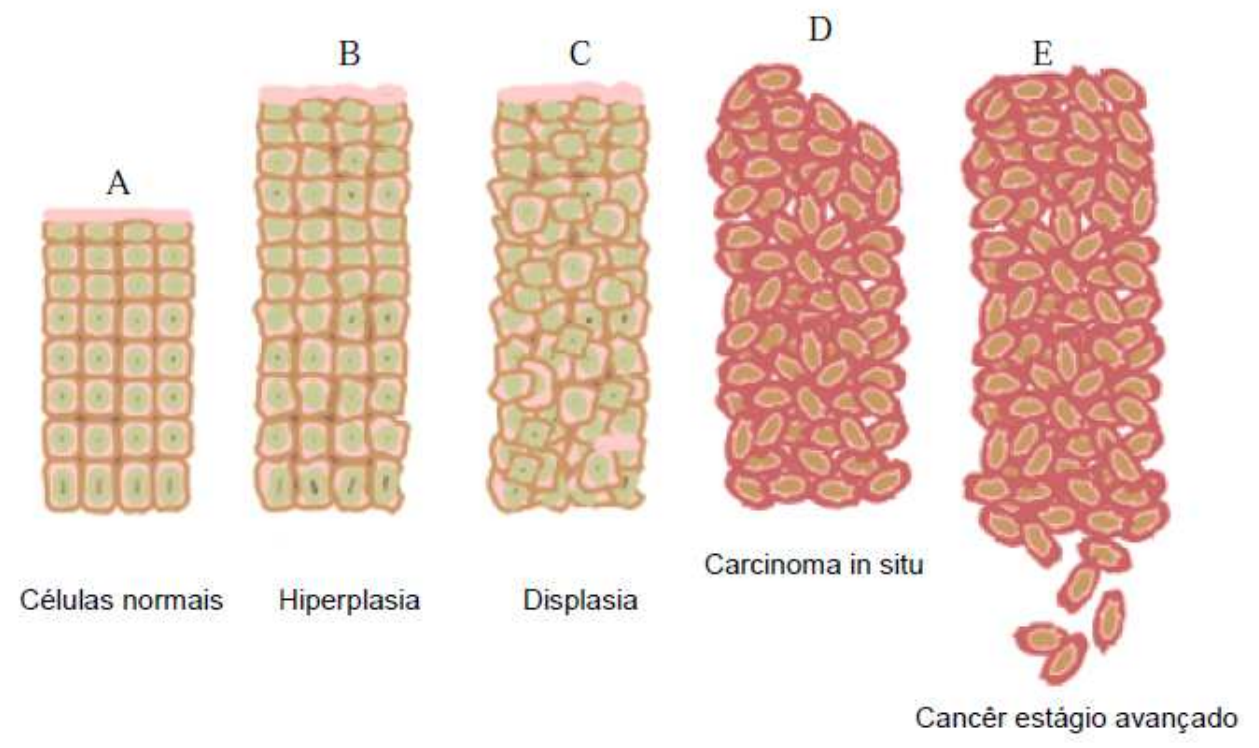

Figura 7. Estágios de progressão do câncer: (A). Células normais; (B). Estágio de Iniciação: mutação genética. (C). Promoção: transformação maligna da célula; (D). Progressão: proliferação celular descontrolada. (E). Estágio de Câncer avançado. (Imagem retirada do Instituto Nacional do Câncer - http://press2.nci.nih.gov/sciencebehind/cancer/cancer01.htm).

\subsubsection{Resistência a morte celular}

Células tumorais alteraram a sinalização da apoptose e prosseguem na via de proliferação celular. A via de sinalização da proteína P53, dentre outras funções, controla a expressão e atividade de moléculas bloqueadoras do ciclo celular e a indução da apoptose. Essa via é bloqueada em aproximadamente $50 \%$ dos tipos de câncer que, dessa forma, impedem a ativação da mesma (Chipuk et al., 2006). Outros mecanismos de resistência a apoptose presentes no câncer podem ser: o aumento na expressão de proteínas anti-apoptóticas (Bcl-2; $\quad \mathrm{Bcl}-\mathrm{x})$ e mutação/supressão das pró-apoptóticas (Bax, Bin), além de alterações na expressão de receptores transmembrana sinalizadores de apoptose (Weinberg, 2006; Hanahan \& Weinberg, 2011). 


\subsubsection{Potencial de replicação}

As divisões no processo de replicação de células diplóides normais possuem um numero é controlado, ocorrendo apenas de 60 a 70 vezes. Ao atingir esse limite, as células são induzidas à senescência e depois à morte. $\mathrm{O}$ número definido de divisões é determinado pela extensão dos telômeros, localizados na porção final dos cromossomos, que diminuem a cada ciclo celular. Entretanto, em células tumorais, a extensão dos telômeros é estabilizada pelo aumento na expressão de telomerase, mantendo assim um número infinito de replicações (Weinberg, 2006; Hanahan \& Weinberg, 2011).

\subsubsection{Angiogênese auto-sustentada}

Os tumores assim como em tecidos normais necessitam receber um aporte de oxigênio e nutrientes e jogar fora gás carbônico e metabólitos. Essas necessidades são supridas pela ativação constante de um processo de angiogênese, pelo qual vasos sanguíneos normalmente quiescentes são induzidos a proliferar e se expandir pelo tumor. Devido a um desbalanço dos fatores próangiogênicos, os vasos sanguíneos recém-formados são tipicamente aberrantes. Apresentam muitas ramificações, fluxo sanguíneo "defeituoso", pequenas hemorragias e proliferação anormal de células endoteliais (Weinberg, 2006; Hanahan \& Weinberg, 2011).

\subsubsection{Invasão e metástase}

Invasão e metástase é um processo caracterizado por uma seqüência de etapas decorrentes de sucessivas mudanças nas células. Ocorrendo primeiro uma invasão local de células tumorais para vasos sanguíneos e/ou linfáticos próximos. Para realizar essa invasão, as células tumorais diminuem a expressão de junções de adesão diminuindo dessa forma, sua adesão a outras células e também com a matriz extracelular. As células seguem pelos vasos, escapam para o parênquima de um tecido mais distante, formam pequenos nódulos e, finalmente, estabelecem tumores macroscópicos. A comunicação das células tumorais com células do estroma é importante para esse processo. Por exemplo, macrófagos podem facilitar 
Avaliação dos efeitos citotóxicos e antiproliferativos da secreção cutânea e de peptídeos bioativos do anuro Physalaemus nattereri (Steindachner, 1863)

a invasão local secretando metaloproteases e cisteínoproteases relacionadas com a destruição da matriz extracelular (Weinberg, 2006; Hanahan \& Weinberg, 2011).

\subsubsection{Fatores facilitadores e características dos tumores}

A instabilidade genética e a inflamação têm sido descritos como facilitadores no estabelecimento das características do câncer. A instabilidade genética faz com que ocorram mutações randômicas, incluindo rearranjos de cromossomos e mutação raras. A inflamação também está relacionada à progressão dos tumores. As inflamações ocorrem em lesões pré-malígnas e malígnas e é ocasionada por células do sistema imune ali presentes (Hanahan \& Weinberg, 2011).

A habilidade das células tumorais em mudar o metabolismo energético e driblar o sistema imune são duas importantes etapas para o desenvolvimento do câncer e foram classificadas por Hanahan \& Weinberg (2011) como características emergentes (Figura 8), por não estarem, infelizmente, elucidadas. Células tumorais apresentam alguns ajustes no metabolismo energético para manter as taxas de proliferação celular. Mesmo na presença de oxigênio, as células reprogramam seu metabolismo de glicose limitando-o principalmente à etapa da glicólise.

Aparentemente, esse reajuste não parece conferir vantagens energéticas, uma vez que a glicólise produz 18 vezes menos energia que a fosforilação oxidativa. No entanto, o aumento nas taxas de glicólise permite a entrada de diversos intermediários glicolíticos em vias de biossíntese, facilitando a produção de macromoléculas e organelas necessárias para as novas células (Hanahan \& Weinberg, 2011).

As células do sistema imune monitoram tecidos constantemente e são capazes de identificar e destruir células tumorais, estas células são caracterizadas por serem altamente imunogênicas. Pórem, alguns tumores conseguem evadir do sistema imune evitando serem detectados ou limitando sua atuação. Os mecanismos utilizados pelas células tumorais ainda estão sendo investigados, no entanto algumas características são clássicas. Por exemplo, células tumorais paralisam a "infiltração" das células do sistema imune secretando fatores imunossupressores. A figura 8. mostra as características tumorais discutidas e 
ilustram a complexidade dos mecanismos celulares envolvidos na progressão do câncer (Weinberg, 2006; Hanahan \& Weinberg, 2011).

O câncer sendo uma patologia complexa de incidência multifatorial, que as taxas de incidência ao longo dos anos têm aumentado e que os tratamentos disponíveis são honerosos e nem sempre resultam na cura, a implementação de medidas de prevenção e de detecção precoce, vêm sendo apontada como uma estratégia eficiente e mais barata para a redução nas taxas de incidência e mortalidade (Thun et al., 2010).

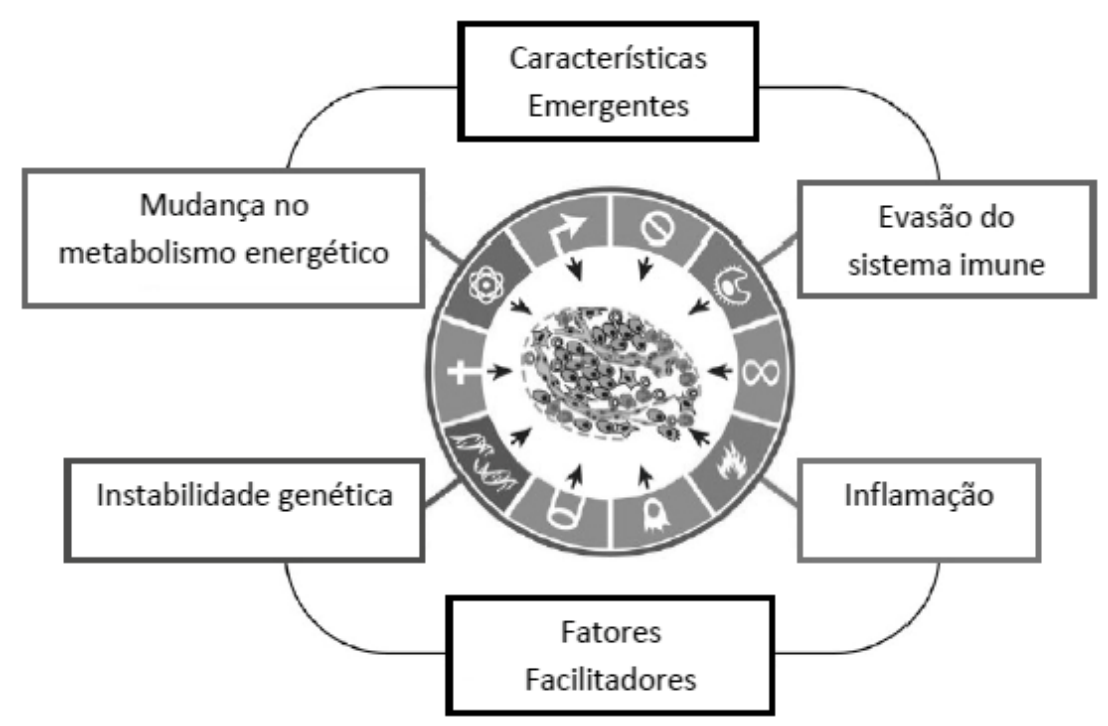

Figura 8. Fatores que ocasionam o câncer e características do processo de desenvolvimento do câncer. Adaptado de Hanahan \& Weisberg, 2011.

As informações sobre a correlação entre fatores de risco e incidência da doença permite concluir que uma proporção considerável dos casos de câncer no mundo poderiam ser prevenidos com programas de controle do consumo de tabaco, vacinações contra agentes infecciosos, exames periódicos, bem como a implementação de campanhas de saúde pública, promovendo a prática de exercícios físicos e uma alimentação mais saudável (Thun et al., 2010).

A intensificação nos estudos e pesquisas sobre fatores de risco para o desenvolvimento do câncer, bem como pesquisas enfatizando a busca por compostos naturais ou sintéticos que possam atuar como agentes preventivos 
também contribuem para a redução das taxas de incidência da doença (Thun et al., 2010).

\subsubsection{Câncer de pele}

É o câncer mais freqüente no Brasil e corresponde a $25 \%$ de todos os tumores malignos registrados no país. O número de novos casos de câncer de pele não-melanoma estimado para o Brasil no ano de 2015 é de 98.420 entre homens e de 83.710 nas mulheres. Esses valores correspondem a um risco estimado de 100,75 casos novos a cada 100 mil homens e 82,24 a cada 100 mil mulheres. As maiores taxas estimadas em homens encontram-se na Região Sul,( (159,51/ 100 mil) Sudeste (133,48/ 100 mil) e Centro-Oeste (110,94/ 100 mil) Nas regiões Nordeste $(40,37 / 100$ mil) e Norte (28,34/ 100 mil), encontra-se na segunda posição.

Nas mulheres, é o mais frequente em todas as regiões, com um risco estimado de 112,28/ 100 mil no Sudeste, 99,31/ 100 mil no Centro-Oeste, 86,03/ 100 mil no Sul, 46,68/ 100 mil no Nordeste e 24,73/ 100 mil no Norte (INCA, 2014).

O câncer de pele tem distribuição universal e costuma apresentar-se sob três principais formas: melanoma, carcinoma basocelular e carcinoma espinocelular (ou epidermoide). Os carcinomas basocelular e epidermoide são também conhecidos como câncer de pele não melanoma, tipo mais frequentes de câncer de pele e câncer mais frequente na população de pele clara. A exposição excessiva ao sol é o principal fator de risco para o surgimento dos cânceres de pele melanoma e não melanoma. O carcinoma epidermoide ocorre quase exclusivamente em áreas expostas continuamente à radiação solar, enquanto o carcinoma basocelular pode ocorrer em áreas do corpo expostas à radiação solar de forma intermitente. Para o melanoma, a presença de numerosos nevos (sinais) cutâneos aumenta o risco (INCA, 2014). O que devemos considerar no melanoma é que, sua letalidade é elevada; porém sua incidência é baixa.

A incidência dos cânceres de pele não melanoma aumenta com a idade, em especial a incidência do carcinoma epidermoide. O carcinoma basocelular é mais frequente que o carcinoma epidermoide, e ambos são mais frequentes nos homens do que nas mulheres. Os cânceres de pele não melanoma são de bom prognóstico, com altas taxas de cura se tratados de forma precoce e adequada. Contudo, 
situações nas quais há demora no diagnóstico podem acarretar ulcerações na pele e deformidades físicas graves.

O câncer de pele melanoma é menos frequente do que os outros tumores de pele. Também é mais frequente em populações de pele clara e expostas à radiação solar. Indivíduos de pele escura possuem menor risco de apresentá-lo. Seu prognóstico é bom para os tumores localizados, enquanto, para melanomas metastáticos, é reservado (INCA, 2014).

O câncer de pele é caracterizado por uma proliferação descontrolada de células presentes nas diversas camadas da epiderme. O desenvolvimento do câncer de pele depende do tipo de célula mutada. De uma forma geral, mutações em células basais desenvolvem-se em cânceres de crescimento lento com raras metástases (carcinoma basocelular); já mutações em células escamosas desenvolvem-se em cânceres com maior propensão à metástase (carcinoma epidermóide) (NIH, 2005). Mutações ocorridas nas células produtoras de melanina, os melanócitos, culminam no desenvolvimento do melanoma. Esse tipo de câncer freqüentemente está associado a metástases agressivas, podendo migrar para qualquer parte do corpo e se instalar em linfonodos, fígado, pulmões e cérebro. Os principais sintomas do câncer de pele são a incidência e/ou alterações na cor, textura e forma de manchas e pintas $(\mathrm{NIH}, 2009)$. Dentre os fatores de risco para o câncer de pele destacam-se: a radiação ultravioleta (principal), fatores genéticos, cor de pele branca, cicatrizes, queimaduras, infecções de pele, dentre outros. O câncer de pele não-melanoma apresenta altos percentuais de cura, se for detectado precocemente. Os principais tratamentos utilizados atualmente são: cirurgia, quimioterapia, radioterapia e a terapia fotodinâmica. A aplicação dos tratamentos varia de acordo com o estágio de desenvolvimento do tumor (NIH, 2009).

A cirurgia consiste na remoção total ou parcial da lesão. Tal procedimento pode causar efeitos adversos como cicatrizes profundas. A radioterapia apresenta efeitos adversos como secura e vermelhidão na área tratada. Alguns efeitos adversos da quimioterapia consistem: no inchaço, dor, feridas, vermelhidão, entre outros. A terapia fotodinâmica consiste na ativação de um fármaco, aplicado no local da lesão, por um laser e posterior destruição do tumor. Os efeitos adversos desse tratamento são feridas e vermelhidão no local (NIH, 2009). 
No Brasil, o câncer de pele não melanoma é o tumor mais incidente em ambos os sexos. É provável que exista um sub-registro dessa neoplasia, em função do subdiagnóstico. Consequentemente, as estimativas das taxas de incidência e dos números esperados de casos novos em relação a esse tipo de câncer devem ser consideradas como estimativas mínimas (NIH, 2009).

Ações de prevenção primária, como a proteção individual contra a luz solar, são altamente efetivas e de custo relativamente baixo para a prevenção do câncer de pele, inclusive dos melanomas. A educação em saúde para a população e a promoção de ambientes que propiciem a proteção contra as radiações solares, principalmente nos ambientes de trabalho e lazer, também são efetivas para a coletividade. É recomendável que o indivíduo sob risco procure um dermatologista ao primeiro sinal de surgimento de novas manchas ou sinais na pele, ou modificações na cor, tamanho e bordas de lesões antigas, permitindo identificar possíveis cânceres precocemente $(\mathrm{NIH}, 2009)$.

\subsubsection{Câncer do colo uterino}

Para o ano de 2014, no Brasil, são esperados 15.590 casos novos de câncer do colo do útero, com um risco estimado de 15,33 casos a cada 100 mil mulheres. $O$ câncer do colo do útero é o mais incidente na região Norte (23,57/ 100 mil). Nas regiões Centro-Oeste (22,19/ 100 mil) e Nordeste (18,79/ 100 mil), é o segundo mais frequente. Na região Sudeste (10,15/100 mil), o quarto e, na região Sul (15,87 /100 mil), o quinto mais freqüente.

Configurando-se como um importante problema de saúde pública, segundo as últimas estimativas mundiais no ano de 2014, o câncer do colo do útero foi o quarto tipo de câncer mais comum entre as mulheres, com 527 mil casos novos. Sua incidência é maior em países menos desenvolvidos quando comparada aos países mais desenvolvidos. Em geral, começa a partir de 30 anos, aumentando seu risco rapidamente até atingir o pico etário entre 50 e 60 anos. Esse câncer foi responsável pelo óbito de 265 mil mulheres em 2012, sendo que 87\% desses óbitos ocorreram em países em desenvolvimento. Assim, para o câncer de colo do útero, o já citado estudo do INCA apresentou uma sobrevida aproximada de $70 \%$. 
O tipo histológico mais comum do câncer do colo do útero é o carcinoma de células escamosas, representando cerca de $85 \%$ a $90 \%$ dos casos, seguido pelo tipo adenocarcinoma. O principal fator de risco para o desenvolvimento de lesões intraepiteliais de alto grau (lesões precursoras do câncer do colo do útero) e do câncer do colo do útero é a infecção pelo papilomavírus humano (HPV). Contudo, essa infecção, por si só, não representa uma causa suficiente para o surgimento da neoplasia, faz-se necessária sua persistência (NIH, 2009).

Além de aspectos relacionados ao HPV (tipo e carga viral, infecção única ou múltipla), outros fatores ligados à imunidade, à genética e ao comportamento sexual parecem influenciar os mecanismos, ainda incertos, que determinam a regressão ou a persistência da infecção e também sua progressão para lesões precursoras ou câncer. A idade também interfere nesse processo: a maioria das infecções por HPV em mulheres com menos de 30 anos regride espontaneamente, ao passo que, acima dessa idade, a persistência é mais frequente. Como já falado anteriormente, o tabagismo eleva o risco de desenvolvimento do câncer do colo do útero. Esse risco é proporcional ao número de cigarros fumados por dia e aumenta, sobretudo, quando $o$ ato de fumar é iniciado em idade precoce. Existem hoje 13 tipos de HPV reconhecidos como oncogênicos pela IARC (International Agency for Research on Câncer), Desses, os mais comuns são o HPV 16 e 18, responsáveis por cerca de $70 \%$ dos casos desse câncer ( $\mathrm{NIH}, 2009)$.

A vacina contra o HPV é uma promissora ferramenta para o combate ao câncer do colo do útero. Em 2014, o Ministério da Saúde implementou no Sistema Único de Saúde (SUS) a vacinação gratuita de meninas de 9 a 13 anos, com a vacina tetravalente, que protege contra dois principais tipos oncogênicos de HPV (16 e 18). A vacinação, contudo, não exclui as ações de prevenção e de detecção precoce pelo rastreamento, que busca lesões precursoras e câncer em mulheres sem sintomas. Com exceção do câncer de pele, esse tumor é o que apresenta maior potencial de prevenção e cura, quando diagnosticado precocemente. $O$ teste citopatológico convencional (Papanicolaou) é a principal estratégia de programas de rastreamento do câncer do colo do útero no mundo (NIH, 2009). 
No Brasil, a estratégia recomendada pelo Ministério da Saúde é o exame citopatológico em mulheres de 25 a 64 anos. Para a efetividade do programa de controle do câncer do colo do útero, faz-se necessário garantir a organização, a integralidade e a qualidade dos serviços e ações da linha de cuidado, bem como o tratamento e o seguimento das pacientes $(\mathrm{NIH}, 2009)$.

\subsection{Peptídeos anticâncer}

O recente desenvolvimento de tratamentos à base de peptídeos antimicrobianos (PAMs) emergiu como uma nova estratégia à terapia do câncer (Figura 9). O tratamento é bastante viável, pelo fato dos peptídeos serem altamente específicos para os seus alvos e apresentarem baixa toxicidade, boa penetrabilidade nos tecidos, devido aos seus tamanhos reduzidos, atuarem rapidamente, não estimularem o aparecimento de resistência pelas células, apresentarem sinergismo com quimioterápicos clássicos, possuírem atividade em amplo espectro, serem capazes de destruírem tumores primários, além de prevenirem metástase (Shadidi \& Sioud, 2003; Bhutia \& Maiti, 2008; Hoskin \& Ramamoorthy, 2008).

Pesquisas recentes revelaram que muitos peptídeos antimicrobianos apresentavam atividade anticâncer. Esses peptídeos possuem um papel importante na imunidade inata de diversos organismos, além do recente surgimento de evidências de que eles também modulam a imunidade, afetando infecções e inflamações. Estudos sugerem que a atividade antitumoral desses peptídeos surge primariamente da interação com a membrana plasmática das células ou com a membrana mitocondrial (Dennison et al., 2006).

De acordo com o espectro de atividade, os peptídeos antimicrobianos são divididos em dois grupos: O primeiro grupo inclui peptídeos que são extremamente potentes contra bactérias e células de câncer, mas que não afetam células normais de mamíferos (ex: magaininas). O outro grupo é formado por peptídeos tóxicos para bactérias, células tumorais e normais de mamíferos (ex: melittina). No entanto, é bom ressaltar que nem todos os peptídeos antimicrobianos apresentam atividade antitumoral (Papo \& Shai, 2005). 
Um número diversificado de organismos produzem peptídeos anticâncer, no entanto, a maior fonte destes peptídeos (por exemplo, magaininas, dermaseptinas, gaegurinas, aureinas e citropinas) são isolados a partir da secreção cutânea de anuros. Pesquisas revelam que muitos anfíbios possuem secreções glandulares que contêm pelo menos um peptídeo antimicrobiano de amplo espectro, juntamente com outros que apresentam um espectro limitado de atividade contra uma ou poucas bactérias. Muitos desses peptídeos antimicrobianos de amplo espectro de ação apresentam a porção C-terminal amidada e também exibem atividade anticâncer, como é o caso do Hypsiboas albopunctatus, alvo de estudo no presente trabalho. Essa dupla função (atividade antimicrobiana e anticancerígena) sugere que o mecanismo de ação de ambas as atividades é similar (Pukala et al.,2006). Na literatura, existem relatos (Libério et al., 2011; Van Zoggel et al., 2010) de que alguns peptídeos antimicrobianos (PAMs) de amplo espectro também apresentaram atividade anticancerígena.

\subsubsection{Mecanismos de ação dos peptídeos anticâncer}

A) Processos apoptóticos na célula

A apoptose é um processo biológico de morte celular, essencial para a homeostase de um organismo. Também está envolvida na maquinaria de defesa do sistema imune e tem um papel fundamental na proteção do organismo contra a carcinogênese (Fesik, 2005; Ghobrial et al., 2005; Jin \& El-Deiry, 2005). Consiste na autodestruição programada e controlada de uma célula, mediante um estímulo de morte celular (dano no material genético ou restrição energética, por exemplo). Em um sistema vivo, os fragmentos celulares são fagocitados por células próximas sem causar reações inflamatórias no local (Okada \& Mak, 2004).

A célula apoptótica tem como algumas características a perda do volume, condensação da cromatina, degradação do DNA e formação de corpos apoptóticos (fragmentos celulares envoltos por membrana plasmática) (Majno et al., 1995). 
Essas alterações ocorrem em função da regulação de vias de transdução de sinal envolvendo proteínas anti- e pro-apoptóticas, seguida pela degradação proteolítica de componentes celulares (Youle et al., 2008). As caspases são as principais enzimas participantes do processo de ativação da apoptose. Elas clivam substratos vitais das células, causando alterações bioquímicas e morfológicas características desse processo de morte celular (Ghobrial et al., 2005).

A clivagem da lâmina nuclear causa a condensação da cromatina e diminuição do volume do núcleo. A desativação de inibidores de endonucleases induzem a fragmentação do DNA. Proteínas do citoesqueleto também são clivadas pelas caspases, induzindo alterações na morfologia (Savill et al., 2000). A apoptose pode ser ativada por duas vias principais. A via extrínseca inicia-se com a interação de ligantes específicos aos receptores de apoptose localizados na superfície da membrana plasmática, desencadeando a ativação de caspases. A via intrínseca é iniciada após alterações funcionais e/ou estruturais ocorridas na mitocôndria, desencadeando a liberação de moléculas sinalizadoras responsáveis por ativar as caspases (Igney et al., 2002).

Vários peptídeos catiônicos, como magainina 2 e derivados de gaegurina 6 , são capazes de induzir apoptose. Os resultados dos estudos com a magainina sugerem perturbação da membrana mitocondrial, a qual é carregada negativamente, levando à liberação do citocromo c, que promove o processo apoptótico (Kim et al., 2003; Papo \& Shai, 2005; Bhutia \& Maiti, 2008).

\section{B) Processos de necrose da célula}

A maioria dos peptídeos atuantes em membranas se liga rapidamente à membrana plasmática das células tumorais, desestabilizando-a e levando à necrose. A membrana citoplasmática das células cancerígenas hiper-expressa fosfatidilserina carregada negativamente e mucinas $\mathrm{O}$-glicosiladas, o que torna a membrana dessas células mais negativa que a das células eucarióticas normais. Esses peptídeos, freqüentemente pequenos, catiônicos e anfipáticos, causam desestabilização da membrana, tanto pelo modelo carpet-like, como pelo barrel-stave, como descrito acima, levando à morte necrótica das células tumorais, sendo que os peptídeos que 
atuam como no último modelo também lisam células normais. (Papo \& Shai, 2005; Bhutia \& Maiti, 2008).

Os peptídeos necróticos possuem uma alta especificidade para células tumorais, atuam independentemente do estado proliferativo das células e são ativos contra células de câncer resistentes a múltiplas drogas, uma vez que não atuam via receptores. Experimentos demonstraram que o potencial de membrana é fundamental para a atividade desses peptídeos (Papo \& Shai, 2005; Bhutia \& Maiti, 2008). Durante a última década, membros desse grupo foram isolados de Litoria sp. e apresentam atividade contra todas as classes de cânceres humanos testados (Apponyi et al., 2004).

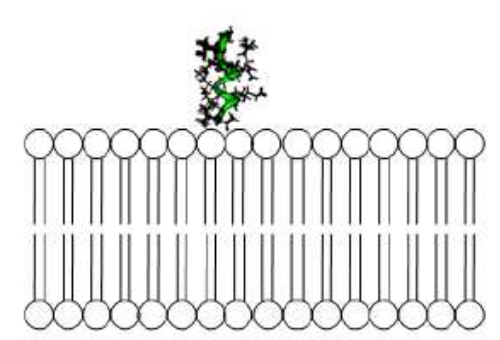

(A). Ancoragem do peptídeo na membrana celular.

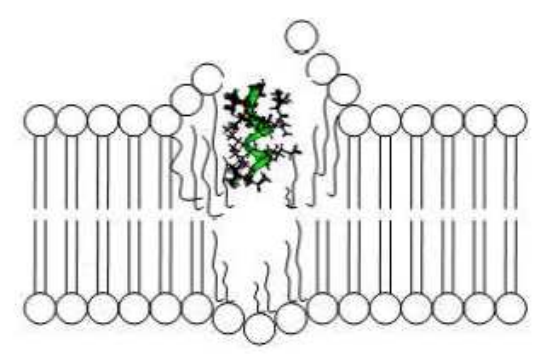

(C). Desmontagem da bicamada lipídica e formação do canal transmembrana.

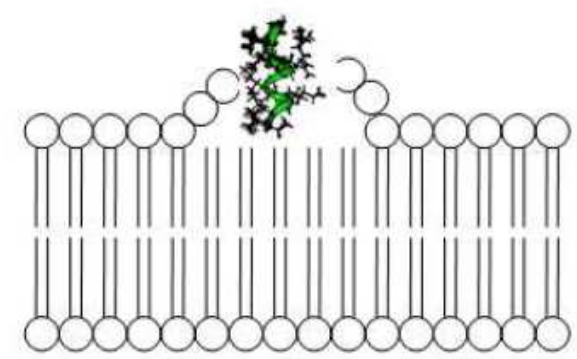

(B). Início da desestabilização da membrana celular.

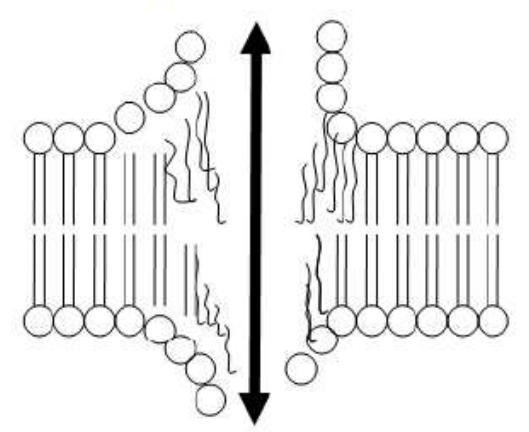

(D). Fluxo de substâncias para o interior e exterior da célula levando a apoptose.

Figura 9. Interação de um peptídeo anticâncer com a membrana celular: (A) ancoragem do peptídeo na membrana celular; (B). Início da desestabilização da membrana celular; (C). Desmontagem da bicamada lipídica e formação do canal transmembrana; (D). Fluxo de substâncias para o interior e exterior da célula levando a apoptose (fonte: wfdaj.sites.uol.com.br). 


\subsubsection{A seletividade dos peptídeos anticâncer pelas células tumorais}

Primeiramente, vale saber que peptídeos anticâncer são agentes que reduzem a freqüência ou a taxa de manifestação de tumores espontâneos ou induzidos, independentemente do mecanismo envolvido. Eles diferem dos antineoplásicos, por impedirem a formação das neoplasias. As substâncias que possuem papel anticâncer podem ser divididas em três categorias:

A primeira consiste em compostos que impedem a formação de carcinógenos a partir de substâncias precursoras; A segunda categoria consiste em "agentes bloqueadores" que inibem a carcinogênese impedindo-os de alcançarem ou de reagirem com os alvos críticos nos tecidos; O terceiro grupo é formado pelos "agentes supressores" que agem suprimindo a expressão da neoplasia em células que foram previamente expostas a carcinógenos que, de outra forma, causariam neoplasia (Figura 10). (Dennison et al., 2006; Hoskin \& Ramamoorthy, 2008).

Mudanças que ocorrem na membrana da célula contribuem para o desenvolvimento do câncer, para imitar a expressão de certos constituintes na membrana, promovendo a habilidade de crescer na ausência de sinais estimulatórios, de atacar e responder diferentemente às células vizinhas, e afetar a mobilidade das células cancerígenas, facilitando a invasão e a metástase. Diferenças entre a membrana das células tumorais e normais fazem os peptídeos anticâncer apresentarem especificidade frente às células tumorais. As interações eletrostáticas entre os peptídeos anticâncer catiônicos e os componentes aniônicos da membrana celular são as maiores responsáveis pela especificidade desses peptídeos. As membranas das células cancerígenas são carregadas negativamente devido à presença de moléculas aniônicas, tais como as fosfotidilserinas, as mucinas O-glicosiladas e ácido siálico, como ressaltado anteriormente, diferentemente das células normais que possuem membranas neutras (Dennison et al., 2006; Hoskin \& Ramamoorthy, 2008). 


\subsubsection{Estratégias para aumentar a eficiência dos peptídeos anticâncer}

Substâncias originadas de fontes naturais há muito tempo são utilizadas no tratamento de inúmeras enfermidades que acometem os seres humanos. Grande parte dos medicamentos encontrados no mercado é derivado direto ou indiretamente de vegetais, microrganismos, organismos marinhos, vertebrados e invertebrados terrestres. (Newman et. al., 2000). Analisando os medicamentos disponibilizados no mercado entre 1981 e 2002, observa-se que $28 \%$ destes possuem princípios ativos isolados de produtos naturais, semi-sintéticos ou sintéticos, ao passo que $24 \%$ são sintéticos com grupos farmacofóricos baseados em estruturas bioativas (Newman et. al., 2003).

Apesar do grande potencial terapêutico, o uso de peptídeos naturais tem sido inviabilizado por inúmeros fatores, como meia-vida curta no sangue, baixa biodisponibilidade em tecidos e órgãos, depuração renal e potencial ativação do sistema imune (Shadidi \& Sioud, 2003). O desenvolvimento de terapias baseadas em peptídeos deve possuir forte atividade tumoricida e baixa toxicidade (Kim et al., 2003).

Uma alternativa é a funcionalização dos peptídeos anticâncer, isto é, a utilização desses peptídeos com quimioterápicos convencionais ou moléculas radiomarcadas, por exemplo, o uso de peptídeos antagonistas de receptores conjugados às drogas tradicionais utilizadas no tratamento de câncer. Essas pró-drogas são desenhadas pela fusão de quimioterápicos a peptídeos, que se ligam especificamente a células tumorais com um sítio de clivagem que é reconhecido pelas proteases associadas ao tumor (Shadidi \& Sioud, 2003). Finalmente, o potencial desses peptídeos pode ser aumentado por meio de sistemas de entrega. Carreadores de drogas e associação com soro albumina estão sendo usados para aumentar a longevidade, estabilidade, permeabilidade e retenção no corpo dessas moléculas (Zhu \& Witte, 1999; Brannon-Peppas \& Blanchette, 2004; Papo \& Shai, 2005). 
Outra estratégia que representa um importante passo no uso de peptídeos líticos na terapia do câncer é o uso da entrega de genes codificadores de peptídeos líticos nas células tumorais por vetores (Winder et al., 1998; Brannon-Peppas \& Blanchette, 2004).

Infelizmente, os custos para isolar e sintetizar peptídeos anticâncer de origem natural ainda é muito elevado. Investimentos das indústrias farmacêuticas levarão, em um futuro próximo, ao desenvolvimento de novas técnicas que viabilizarão a comercialização dessas moléculas, as quais serão uma alternativa real aos quimioterápicos atuais (Hoskin \& Ramamoorthy, 2008).

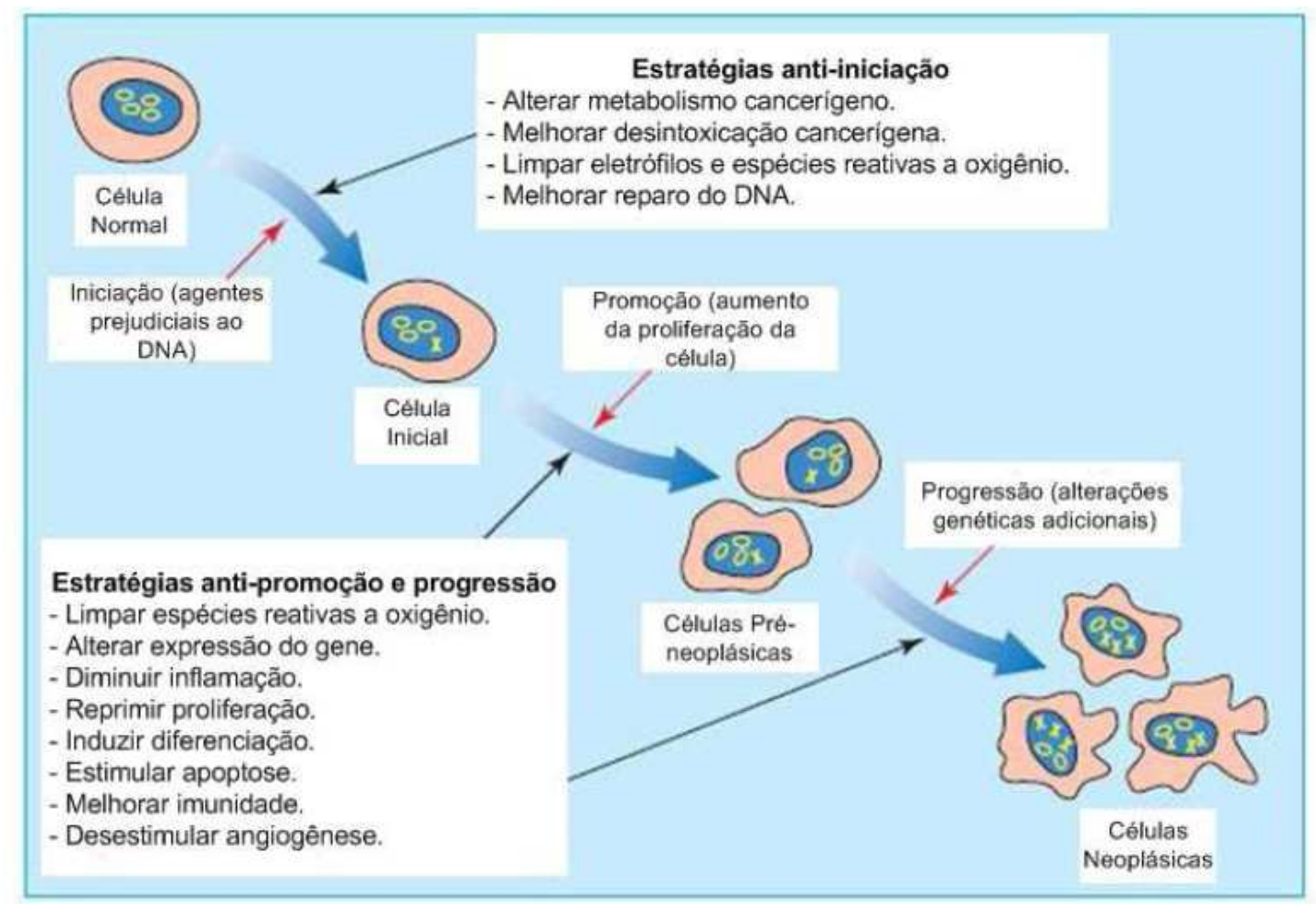

Figura 10. Multi-estágios da carcinogênese: processos e estratégias de prevenção. A iniciação é caracterizada pela conversão de uma célula normal em uma célula inicializada, em resposta a agentes prejudiciais ao DNA (dano genético indicado por um X). A promoção caracteriza-se pela transformação de uma célula inicializada em uma população de células pré-neoplásicas, resultado de alterações na expressão de genes e proliferação celular. A progressão inclui a transformação das células pré-neoplásicas em uma população de células neoplásicas como resultado de alterações genéticas adicionais (modificado de Peter Greenwald 2002). 


\subsection{Physalaemus nattereri (Steindachner, 1863)}

O anuro Physalaemus nattereri (Figura 11) é conhecido como rã-piadeira e pertence à família Leptodactylidae. É uma família exclusivamente encontrada nas Américas, com mais de 800 espécies e cerca de 50 gêneros (Freitas \& Silva, 2007). Possuem espécies que vão de apenas um centímetro de comprimento, como a rã-pulga (Adelophryne sp) até as gigantes rãs-pimenta do gênero Leptodactylus, que podem atingir até $25 \mathrm{~cm}$ de comprimento rostro-anal e pesar até $1,1 \mathrm{~kg}$. (Freitas \& Silva, 2007).

O modo de reprodução da maioria das espécies é deposição de ovos em ninhos de espuma feitas pelo macho, que esfrega rapidamente o muco presente no dorso e região inguinal da fêmea. Esta espuma possui propriedades que protegem os ovos contra a ação de microorganismos e ressecamento, favorecendo assim a espera de maior volume de água para os girinos. Estes ninhos de espuma são feitas principalmente pelos indivíduos dos gêneros Leptodactylus, Pleurodema e Eupemphix e, após um período variável entre um ou alguns dias, os ovos eclodem e os girinos nascem e completam o seu ciclo em lagos temporários, lagoas ou riachos (Freitas \& Silva, 2007).

$P$. nattereri é uma espécie de $4,0 \mathrm{~cm}$ de comprimento rostro-cloacal e possuem hábito noturno. Possui colorido de fundo cinza-prateado com diversas estrias negras espalhadas por todo o corpo. O primeiro registro de distribuição geográfica faz alusão à região central do Brasil (Steindachner, 1863; Melo \& Silva et al., 2008). No entanto, a sua presença foi descrita também na Bolívia (Riva et al., 2000), na Argentina (Lavilla et al., 2001) e no Paraguai (Brusquetti e Lavilla, 2006). Essa espécie de anuro é também encontrada no cerrado brasileiro, e nas áreas de transição entre a caatinga e o cerrado do oeste da Bahia e Piauí (Freitas \& Silva, 2004 apud Freitas \& Silva, 2007).

De acordo com a literatura há pouquíssimos relatos de substâncias produzidas e secretadas na sua pele (Mattos et al., 2003). Uma de suas características mais notáveis é a presença, tanto em indivíduos machos quanto em fêmeas, de um par de glândulas arredondadas e negras na região inguinal. (Figuras 11 e 12). 
Estudos demonstram que o comportamento de defesa dessa espécie ocorre em duas etapas: quando ameaçado, $P$. nattereri geralmente apresenta um comportamento característico que consiste no inchaço lateral do corpo devido ao inflamento dos pulmões, em seguida, o animal vira de costas para o agente que oferece perigo e eleva a parte traseira. Nessa posição, as glândulas negras inguinais ficam expostas juntamente com o cóccix, dando a impressão de se tratar de uma face com grandes olhos negros. Tal efeito visual de alerta, muitas vezes já é suficiente para desencorajar 0 ataque de potenciais predadores visualmente orientados. Caso esse comportamento não seja suficiente e o predador insista no ataque, no momento da mordida, sua mucosa oral entra em contato com a secreção expelida pelas glândulas do anfíbio, causando assim seu envenenamento (LenziMattos et al., 2005).
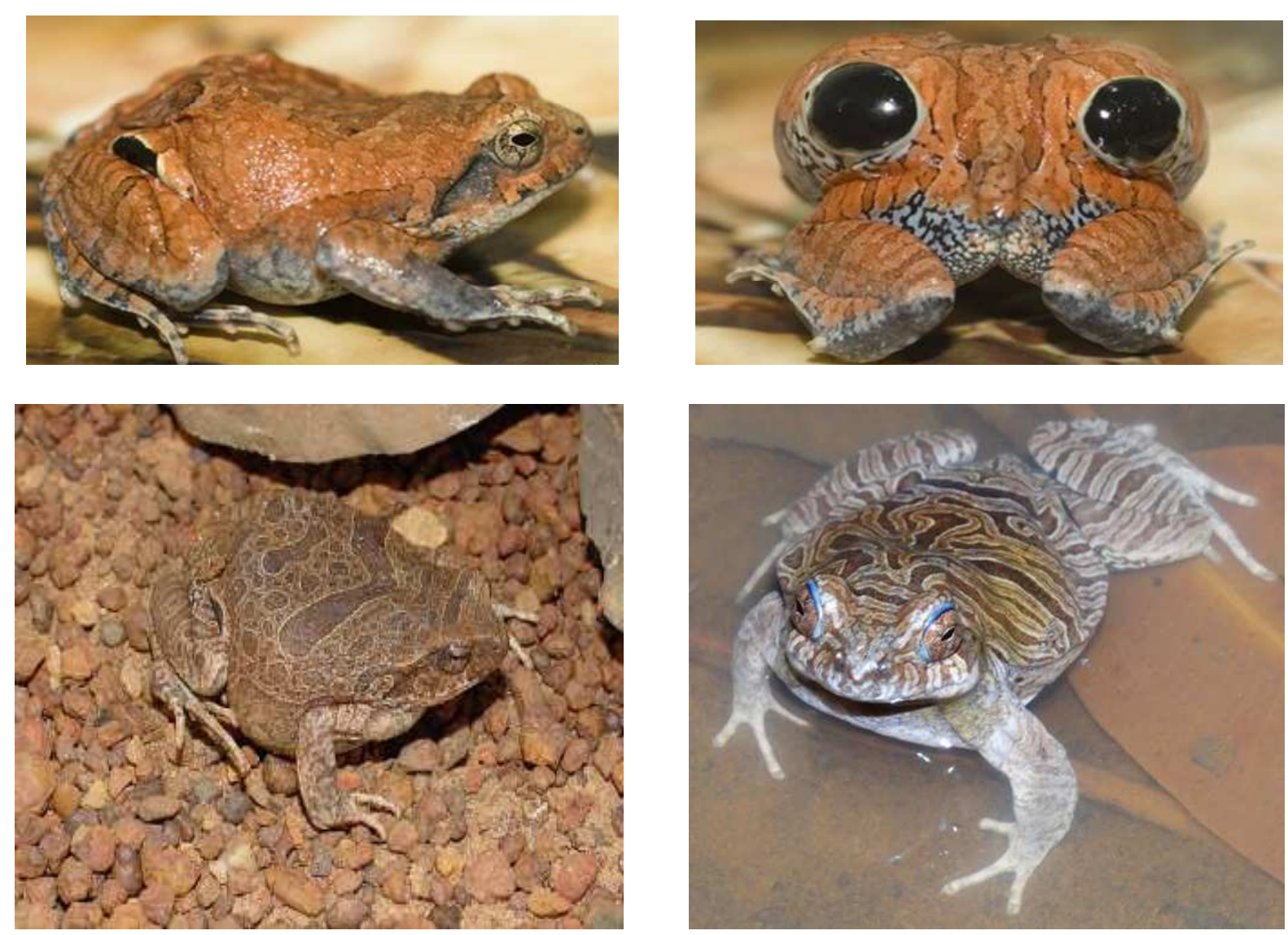

Figura 11. Physalaemus nattereri (Foto de Carlos Candido, Tony Gamble e Lenzi-Mattos et al.). 2005). 
Avaliação dos efeitos citotóxicos e antiproliferativos da secreção cutânea e de peptídeos bioativos do anuro Physalaemus nattereri (Steindachner, 1863)

A

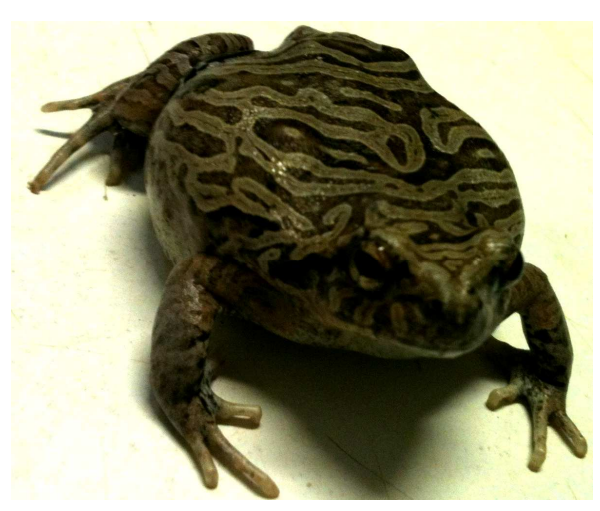

B

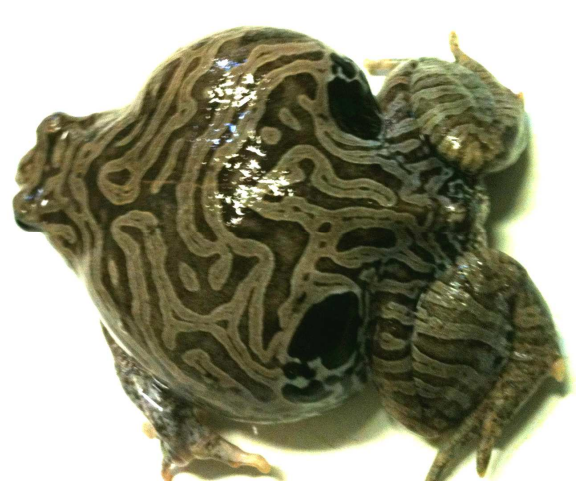

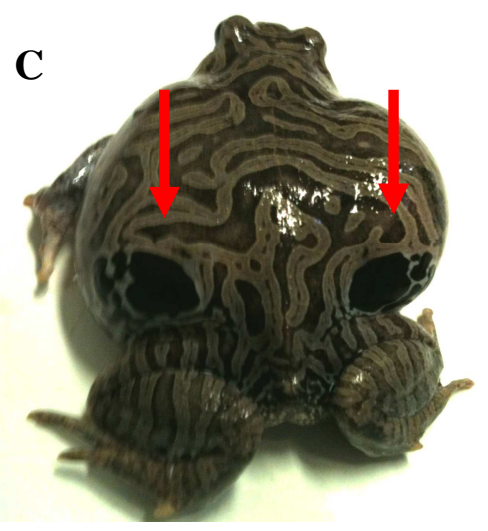

Figura 12. Physalaemus nattereri: A) Vista frontal normal; B) lateral; e C). Vista traseira, mostrando as macroglândulas, inguinais (setas), durante comportamento de defesa com exibição das glândulas inguinais. Imagens: Andréa Carvalho 
Avaliação dos efeitos citotóxicos e antiproliferativos da secreção cutânea e de peptídeos bioativos do anuro Physalaemus nattereri (Steindachner, 1863)

2. Justificativa 


\section{Justificativa}

Melanoma é um dos três tipos mais comuns de câncer de pele que, apesar de muitos avanços no tratamento, ainda é considerado uma das doenças mais devastadoras do mundo moderno. O melanoma ocorre em melanócitos presentes na pele afetando principalmente pessoas caucasianas $(\mathrm{NIH}, 2010)$. Este tipo de câncer de pele provoca grandes problemas de saúde pública, devido à incidência de 3-8\% ao ano (Thompson et al., 2005). Isso ocorre principalmente devido a um aumento da exposição ambiental aos raios ultravioleta, que pode induzir anormalidades nas vias genéticas de melanócitos. Normalmente o tratamento do melanoma inclui cirurgia, apesar de que alguns casos de tumores avançados exigirem o uso de terapias sistêmicas com o uso de agentes quimioterápicos: como dacarbazina, fotemustina e temozolomida. No entanto, os tratamentos convencionais nem sempre resultam em resultados satisfatórios, uma vez que as células cancerosas freqüentemente desenvolvem resistência a esses tratamentos ou ainda exibem baixas taxas de resposta aos quimioterápicos (Subik et al., 2010, e Thompson et al., 2005).

Configurando-se como um importante problema de saúde pública, segundo as últimas estimativas mundiais no ano de 2014, o câncer do colo do útero foi o quarto tipo de câncer mais comum entre as mulheres, Sua incidência é maior em países menos desenvolvidos quando comparada aos países mais desenvolvidos. Com exceção do câncer de pele, esse tumor é o que apresenta maior potencial de prevenção e cura, quando diagnosticado precocemente. No entanto, assim como o câncer de pele, tratamentos convencionais por vezes, não são satisfatórios, isto é justififcado pela resistência das células tumorais aos fármacos tradicionais. Atualmente, a indústria farmacêutica enfrenta uma estagnação na produção de novos antimicrobianos e antibióticos, o que é preocupante, uma vez que diversas bactérias patogênicas têm apresentado resistência aos medicamentos comercialmente disponíveis como vimos anteriormente. A resistência de patógenos a antimicrobianos é o maior problema clínico mundial de interesse na saúde pública. Segundo Okeke et al. (2005) e French (2005), a presença dos microrganismos resistentes afetam, não somente a mortalidade, mas também o custo do tratamento, a expansão da doença e a duração da mesma. Diversas estratégias estão emergindo para contribuir na solução desse problema. 
Dentre as soluções correntes, encontram-se o uso dos antimicrobianos com parcimônia e a descoberta de novos antimicrobianos alternativos. A expectativa é que a utilização da engenharia de proteínas na produção de novas drogas venha a se tornar uma aliada importante e eficiente no controle de organismos patogênicos. Neste contexto, os PAMs e PACs são moléculas efetoras naturais do sistema imune inato de diferentes seres vivos, atuando como primeira linha de defesa contra microrganismos. Também são compostos bioativos, potencialmente bons candidatos para novos agentes terapêuticos, menos propenso aos fenômenos de resistência pelos microrganismos e inócuos para a saúde humana. Estudos ao longo dos anos revelaram diversas funções para os peptídeos antimicrobianos. Dentre essas funções, destacam-se as atividades antimicrobiana, antitumoral, antiviral, contraceptiva e antiparasitária. Entretanto, os peptídeos que possuem atividade antimicrobiana (não excluindo as outras funções) são os mais procurados, devido à crescente resistência aos antibióticos convencionais e a necessidade de novos antibióticos para a terapia humana (Zasloff, 2002). Potenciais moleculas antimicrobianas devem apresentar uma toxicidade seletiva, rápida ação, amplo espectro de ação antimicrobiano, e não selecionar mecanismos de resistência nos microrganismos (Matsuzaki et al., 1999).

Portanto, o desenvolvimento de novas drogas se faz necessário, pois estariam exercendo um papel importante no tratamento do câncer, e patologias microbianas, assim como também nos casos de câncer, em seus inúmeros efeitos colaterais existentes nos tratamentos convencionais (Pukala et al., 2006; Reddy et al., 1996; Reddy et al., 2004; Krugliak et al., 2000; Mangoni et al., 2006). Embora uma série de novos agentes farmacológicos sozinho ou em combinação tenha surgido recentemente nos testes clínicos, ainda assim, a descoberta de novas fontes de biomoléculas com potencial anticancerígeno é um desafio para a indústria farmacêutica. Diante dessas considerações, o veneno dos anfíbios pode tornar-se uma fonte importante de tais moléculas. Os anuros de modo geral já são reportados na literatura pela ação de sua secreção cutânea e o potencial que a mesma exibe, tendo inclusive sido utilizada por muitas culturas diferentes em todo o mundo em aplicações terapêuticas (Nogawa et al., 2001; Ye M, et al., 2005, e Liu Y, et al., 2010). Este conhecimento tradicional levou ao conceito de que a secreção cutânea 
desses anfíbios poderia ser utilizada como uma fonte rica de novos compostos biologicamente ativos. Pesquisas sobre secreções cutâneas de anuros em relação à presença de aminas biogênicas, bufadienolídeos, alcalóides, e peptídeos foram descritos há duas décadas (Toledo et al., 1995 e Clarke et al., 1997), e investigações adicionais foram realizados, a fim de isolar e caracterizar compostos ativos de pele desses anuros. Estes estudos têm demostrado que as glândulas dérmicas sintetizam e excretam uma variedade de hormônios, neuropeptídeos e cininas, bem como peptídeos opióides e peptídeos antimicrobianos citoliticos. Todos eles estão envolvidos, na defesa contra predação de mamífero e/ou invasão microbiana. Alguns destes péptidos podem agir como agentes antiproliferativos sobre as células cancerosas e pode mesmo permanecer não-tóxico para as células normais (Van Zoggel et al., 2012). Outro foco não menos importante são os tratamentos à base de peptídeos antimicrobianos (PAMs) surgiram como uma estratégia para o tratamento do câncer, uma vez que têm diferentes papéis importantes na imunidade inata de muitos organismos (Libério et al., 2013). A utilização destas moléculas é benéfica, em muitos casos, porque são mais seletivas para a membrana carregada negativamente de células cancerosas; mostram boa penetração nos tecidos devido ao seu tamanho pequeno; não estimulam a resistência da célula; mostram sinergismo com drogas clássicas; tem um amplo espectro de atividade; são capazes de destruir tumores primários; e ainda previnem metástase (Mader e Hoskin, 2006).

Em Physalaemus nattereri (Steindachner, 1863), espécie estudada no presente trabalho, pouco se sabe sobre as propriedades bioquímicas e farmacológicas do seu veneno. Por isso, o foco do presente estudo foi analisar a atividade anticâncer e antimicrobiana de $P$. nattereri visando esclarescer os mecanismos de ação, no seu potencial citotóxico frente às linhagens de melanoma murino (B16F10) e câncer de colo uterino (HeLa) e também sua eficiência terapêutica frente a bactérias Gram-positivas e Gram-negativas. Motivado por esses fatos, o presente trabalho visa à utilização da secreção cutânea como também de seus compostos isolados a partir do anuro Physalaemus nattereri comumente encontrado na fauna brasileira com vistas a fomentar a indústria farmacêutica com novas opções de fármacos direcionados ao controle microbiano e ao tratamento de câncer. 
Avaliação dos efeitos citotóxicos e antiproliferativos da secreção cutânea e de peptídeos bioativos do anuro Physalaemus nattereri (Steindachner, 1863)

3. Objetivo e Metas 


\section{Objetivo e Metas}

\subsection{Objetivo geral}

Avaliar os efeitos citotóxicos e antiproliferativos da secreção cutânea do anuro Physalaemus nattereri sobre células de melanoma murino (B16F10) e câncer do colo uterino (HeLa) in vitro e proceder à identificação e caracterização biológica de peptídeos antimicrobianos e anticâncer presentes nessa secreção.

\subsection{Metas estabelecidas no presente estudo}

3.2.1. Avaliar os efeitos citotóxicos e antiproliferativos sobre diferentes linhagens de células tumorais da secreção cutânea bruta do anuro $P$. nattereri;

3.2.2. Determinar a concentração da secreção cutânea bruta do anuro P. nattereri que inviabiliza $50 \%$ e $75 \%\left(\mathrm{IC}_{50}\right.$ e $\left(\mathrm{IC}_{75}\right)$ das células tumorais (HeLa e B16F10) e fibroblastos normais (NIH-3T3);

3.2.3. Determinar os possíveis alvos terapêuticos e os mecanismos de ação citotóxico da secreção cutânea bruta do anuro $P$. nattereri em células cancerosas, empregando a técnica de citometria de fluxo;

3.2.4. Fracionar a secreção cutânea bruta do anuro P. nattereri, empregando técnicas de cromatografia líquida de alta eficiência em fase reversa (RP-HPLC);

3.2.5. Avaliar a atividade antimicrobiana, hemolítica e anticâncer das frações cromatográficas obtidas com o fracionamento por RP-HPLC secreção cutânea bruta do anuro $P$. nattereri;

3.2.6. Avaliar a homogeneidade das frações ativas, bem como determinar as massas moleculares dos componentes presentes nessas frações, por meio de espectrometria de massa tipo MALDI-TOF;

3.2.7. Purificar por meio de técnicas de cromatografia líquida de alta eficiência em fase reversa (RP-HPLC) os peptídeos antimicrobianos e anticâncer identificados no presente estudo;

3.2.8. Determinar as concentrações inibitórias mínimas (MICs) dos peptídeos antimicrobianos e anticâncer identificados no presente estudo frente à bactérias patogênicas; 
Avaliação dos efeitos citotóxicos e antiproliferativos da secreção cutânea e de peptídeos bioativos do anuro Physalaemus nattereri (Steindachner, 1863)

3.2.9. Avaliar os efeitos citotóxicos e antiproliferativos sobre diferentes linhagens de células tumorais dos peptídeos antimicrobianos e anticâncer identificados no presente estudo;

3.2.10. Determinar a concentração de cada um dos peptídeos antimicrobianos e anticâncer identificados no presente estudo que inviabiliza 50\% e 75\% (IC $\mathrm{I}_{50}$ e $\left(\mathrm{IC}_{75}\right)$ das células tumorais (HeLa e B16F10) e fibroblastos normais (NIH-3T3). 
Avaliação dos efeitos citotóxicos e antiproliferativos da secreção cutânea e de peptídeos bioativos do anuro Physalaemus nattereri (Steindachner, 1863)

\section{Material e Métodos}




\section{Material e Métodos}

* Primeira etapa: Avaliação os efeitos citotóxicos e antiproliferativos da secreção cutânea do anuro Physalaemus nattereri sobre células de melanoma in vitro

\subsection{Ensaios de citotoxicidade sobre linhagens celulares tumorais}

\subsubsection{Linhagens celulares}

As linhagens celulares empregadas no presente trabalho foram HeLa (célula tumoral do colo do útero humano $\mathrm{ATCC}^{\circledR} \mathrm{CCL}-2^{\mathrm{TM}}$ ); B16F10 (células de câncer de melanoma murino $A T C C^{\circledR}$ CRL-6475 ${ }^{\mathrm{TM}}$ ) e NIH-3T3 (célula de fibloblastos murino normal ATCC ${ }^{\circledR}$ CRL- $1658^{\mathrm{TM}}$ ). Todas as células foram obtidas do banco de células American Type Culture Collection (ATCC - Coleção Americana de Cultivos Típicos).

As linhagens celulares $\mathrm{B} 16 \mathrm{~F} 10$ e HeLa são reportadas devido ao conhecimento bem estabelecido de suas características morfológicas, bioquímicas e moleculares. Essas linhagens têm servido como modelos celulares mais utilizados na pesquisa de câncer, tanto no estudo de efeitos de compostos anticâncer, quanto na elucidação dos mecanismos de ação dos mesmos.

A linhagem celular HeLa apresenta um crescimento aderente e morfologia epitelial. Estudos reportam que células de HeLa contêm sequências do vírus papiloma humano (HPV-18). (Rodrigues et al., 2008). A linhagem B16F10 apresenta como característica principal uma elevada característica metastásica, baixa imunogenicidade e moderada virulência (Rodrigues et al., 2008). A linhagem de fibroblastos murinos normais (NIH-3T3) é uma linhagem imortalizada, que cresce de forma aderente ao substrato e apresenta morfologia fusiforme.

Os ensaios de atividade anticâncer foram realizados com materiais rigorosamente esterilizados em autoclave e posteriormente mantidos em câmara de fluxo laminar, cuja luz ultravioleta permaneceu ligada por 30 minutos antes do uso.

Todos os experimentos com as respectivas linhagens celulares foram realizados no Laboratório de Nanobiotecnologia da Universidade de Brasília, sob a coordenação do Prof. Dr. Ricardo Bentes de Azevedo. 


\subsection{Manutenção da cultura de células}

Todos os procedimentos foram realizados com materiais esterilizados e em câmara de fluxo laminar, cuja luz ultra-violeta permaneceu ligada de 30 minutos antes do uso. Alíquotas de células tumorais e fibroblastos foram removidas de um estoque em nitrogênio líquido e descongeladas rapidamente a $37^{\circ} \mathrm{C}$. Alíquotas de $500 \mu \mathrm{L}$ foram lentamente adicionadas em $3 \mathrm{~mL}$ de meio de cultura DMEM completo (tamponado com bicarbonato de sódio, suplementado com 10\% de soro fetal bovino e $1 \%$ de antibiótico). Esse meio de cultura foi utilizado em todos os outros procedimentos experimentais. Em seguida, as células foram centrifugadas a 1000 rpm por 5 minutos, ressuspensas em $5 \mathrm{~mL}$ de meio de cultura DMEM, transferidas para um frasco de cultura de células e incubadas em estufa, a $37{ }^{\circ} \mathrm{C}$ e $5 \%$ de $\mathrm{CO}_{2}$. Para assegurar a qualidade das células que iriam ser utilizadas nos experimentos, a cada 48 horas, o meio de cultura foi substituído por um meio de cultura novo. A cultura de células foi observada em microscópio de luz invertido e monitorada quanto ao crescimento celular, aspectos morfológicos e presença de contaminantes.

\subsubsection{Plaqueamento das células}

Ao atingir o estágio de confluência (elevada densidade de células em uma determinada área), as células foram removidas do frasco de cultura e recultivadas em uma densidade menor seguindo o procedimento descrito a seguir.

$O$ meio de cultura foi descartado e $2 \mathrm{~mL}$ de solução de tripsina-EDTA foram adicionados ao frasco de cultura, para a remoção da monocamada de células. Após 2 minutos de incubação em estufa a $37^{\circ} \mathrm{C}$, a remoção das células foi observada em microscópio de luz invertido. Em seguida, foram acrescentados $2 \mathrm{~mL}$ de meio de cultura para inativar a atividade da tripsina. A suspensão de células foi centrifugada a 1000 rpm por 5 minutos. O sobrenadante foi removido e as células, ressuspensas em meio de cultura. Aproximadamente, $10 \%$ das células foram re-cultivadas em frascos de cultura e incubadas em estufa, a $37{ }^{\circ} \mathrm{C}$ e $5 \%$ de $\mathrm{CO}_{2}$. O restante, ou foi utilizado nos experimentos, ou recebeu a adição de hipoclorito de sódio e detergente e, após 24 horas, foram descartados. Após o término dos experimentos, as células 
de câncer e fibroblastos foram congeladas, de acordo com o procedimento descrito a seguir.

No estágio de confluência, as células foram removidas dos frascos de cultura e centrifugadas (como descrito acima). Após o descarte do meio de cultura, as células foram ressuspensas em meio de congelamento (DMEM, 20\% soro fetal bovino, $1 \%$ de antibiótico, $5 \%$ de DMSO). A suspensão celular foi rapidamente transferida para criotubos, os quais foram identificados e envolvidos por uma espessa camada de papel toalha e mantidos a - 80 C , por 24 horas. Em seguida, os criotubos foram estocados, imersos em nitrogênio líquido.

\subsection{Tratamento das células tumorais com a secreção bruta de}

\section{P. nattereri}

Ao atingir o estágio de confluência, as células de câncer (HeLa, B16F10 e fibroblastos normais (NIH-3T3) foram removidas do frasco de cultura e centrifugadas como descrito anteriormente. O sobrenadante foi descartado e as células ressuspensas em $1 \mathrm{~mL}$ de meio de cultura. Para a determinação do número de células, $10 \mu \mathrm{L}$ da suspensão de células foi adicionado a $40 \mu \mathrm{L}$ de solução de azul tripan $(0,4 \%$ diluídos em PBS, $\mathrm{p} / \mathrm{v})$. Uma alíquota de $8 \mu \mathrm{L}$ dessa mistura foi depositada vagarosamente em uma câmara de Neubauer, onde células presentes nos quatro quadrantes maiores laterais foram contadas em microscópio de luz. O número de células foi determinado pela seguinte fórmula:

$$
\text { Número de células } / \mathrm{mL}=\frac{\text { Número de células contadas }}{\text { Numero de quadrantes contados }(=4)} \times \text { fator de diluição }(=5) \times 10^{4}
$$

As células contadas foram transferidas para placas de cultura e incubadas em estufa a $37{ }^{\circ} \mathrm{C}$ e $5 \%$ de $\mathrm{CO}_{2}$, por 24 horas, para a completa adesão das células no fundo da placa. As células foram transferidas para placas de tamanhos diferentes, dependendo do experimento a ser realizado. Placas de 96 poços foram utilizadas para ensaios de viabilidade celular por MTT (ver descrição abaixo), com concentração inicial de $5 \times 10^{3}$ células/poço. Após o período de incubação na estufa, 
as placas de cultura foram observadas em microscópio de luz invertido para a avaliação da morfologia, dispersão das células pela placa e presença de contaminação.

Essa análise foi realizada para decidir se as células estavam homogeneamente dispersas e saudáveis para serem submetidas aos ensaios com a secreção bruta de $P$. nattereri. $O$ meio de cultura contendo a secreção bruta de $P$. nattereri foi preparado a partir da diluição seriada das soluções estoque desse veneno em meio de cultura. O meio de cultura do grupo controle (ausência da secreção de $P$. nattereri) continha apenas meio DMEM na mesma proporção que foi adicionada aos outros grupos experimentais. O meio de cultura das placas foi substituído pelo que continha os peptídeos. As placas foram incubadas em estufa a ${ }^{37} \mathrm{C}$ e $5 \%$ de $\mathrm{CO}_{2}$, por 24 horas. Após o período de incubação, as células foram preparadas de maneira adequada para a realização dos testes. Todos os experimentos foram realizados em triplicata.

\subsection{Avaliação da viabilidade celular empregando-se o método}

\section{MTT}

A viabilidade celular foi avaliada pelo método de MTT estabelecido por Mosmann (1983). As células tumorais (HeLa e B16F10 e as células normais (fibroblastos da linhagem NIH-3T3) foram cultivadas e tratadas com a secreção bruta de $P$. nattereri em placas de 96 poços, como descrito no item acima. Após o período de incubação de 24 horas, o meio de cultura das placas foi removido, e $150 \mu \mathrm{L}$ de solução de uso de MTT (15 $\mu \mathrm{L}$ de MTT $5 \mathrm{mg} / \mathrm{mL}$ diluídos em $135 \mu \mathrm{L}$ de DMEM completo) foram adicionados em cada poço. As células foram incubadas por 3 horas em estufa a $37^{\circ} \mathrm{C}$ e $5 \%$ de $\mathrm{CO}_{2}$. Em seguida, o meio de cultura foi removido e $100 \mu \mathrm{L}$ de DMSO foram adicionados em cada poço para dissolver o formazan formado. A quantificação do formazan foi feita pela medida da absorbância dos poços no comprimento de onda de $595 \mathrm{~nm}$, em espectrofotômetro conjugado a uma leitora de microplacas (Multiskan® FC, Thermo Scientific, USA).

A viabilidade celular foi determinada pela média da triplicata de cada concentração testada. A partir dos dados obtidos foi elaborada uma curva de inhibição e calculados os valores de $I_{50}$ e $I_{75}$ (concentração que produz uma 
resposta inibitória de 50 e 75\%, respectivamente) com emprego do software Prism versão 5.03 (Graphpad Software).

\subsection{Investigação do mecanismo de ação da secreção cutânea bruta de $P$. nattereri sobre células de melanoma murino (B16F10)}

De modo a investigar o mecanismo de ação da secreção cutânea bruta de $P$. nattereri em células de melanoma, uma concentração capaz de reduzir a viabilidade celular em $75 \%$ foi selecionada $\left(\mathrm{IC}_{75}\right)$. Este valor foi calculado a partir da curva de viabilidade MTT por meio de regressão não-linear. As células foram cultivadas em placas de 12 poços, como descrito acima, e após $24 \mathrm{~h}$ foram incubadas com a concentração do $\mathrm{IC}_{75}$ que havia sido previamente determinada. Após tripsinização, as células foram centrifugadas, e preparadas para os ensaios de citometria de fluxo como descrito abaixo.

\subsection{Análises dos efeitos citotóxicos}

As análises tiveram como objetivo avaliar se o veneno bruto promoveriam efeitos citostáticos em estruturas celulares vitais, causando a morte celular. Os mecanismos de ação relacionados ao bloqueio da proliferação e do ciclo celular também foram observados.

Essas observações forneceram informações valiosas sobre os possíveis mecanismos de ação da secreção cutânea bruta de $P$. nattereri. Tal avaliação é importante, considerando que a proliferação celular descontrolada é uma das principais características do câncer. Além disso, moléculas indutoras de efeitos citostáticos em células tumorais são promissoras para tratamentos terapêuticos da doença.

\subsubsection{Análise dos efeitos sobre a morfologia celular}

A morfologia celular é um importante indicativo de viabilidade. Alterações severas desencadeadas por agentes citotóxicos geralmente culminam na modificação da morfologia celular. A microscopia de contraste de fase consiste na 
passagem da luz do microscópio por um anel de contraste, que atinge a amostra e produz um efeito de destaque, onde estruturas claras ficam mais claras e estruturas escuras ficam mais escuras. Dessa forma, é possível observar e analisar rapidamente a morfologia de células imersas em meio de cultura, sem utilização de fixadores ou corantes. No presente trabalho, após o período de tratamento com os peptídeos e o veneno bruto, as placas de cultura foram observadas em microscópio de contraste de fase invertido, para análise de possíveis alterações morfológicas. A aquisição das imagens foi realizada com o uso de câmera digital acoplada à ocular do microscópio de fase invertido (Zeiss, Alemanha) e os softwares de aquisição foram respectivamente DinoCapture 2.0 Version 1.5.0. e Motic Images Plus 2.0.

Acerca dos ensaios com o veneno bruto, os parâmetros relacionados com o tamanho e granularidade das células tratadas foram obtidos por citometria de fluxo utilizando os canais FSC e SSC respectivamente. Os dados obtidos foram analisados utilizando o programa FlowJo X 10.0.7r2.

\subsubsection{Ensaios Empregando a Técnica de Citometria de Fluxo}

A linhagem celular tumoral de melanoma murino (B16F10) foi transferida para uma placa de 12 poços na concentração de $5 \times 10^{4}$ células/poço e incubadas a temperatura de $37^{\circ} \mathrm{C}$ como descrito acima. As células foram tratadas com a concentração de $0,079 \mu \mathrm{g} / \mathrm{ml}\left(\mathrm{IC}_{75}\right)$ da secreção cutânea bruta de $P$. nattereri

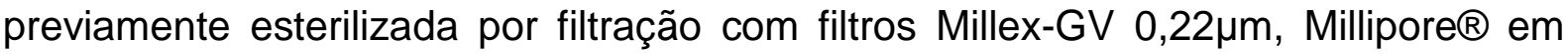
meio de cultura DMEM, com ou sem $10 \%$ soro fetal bovino, por 24 horas $37^{\circ} \mathrm{C}$.

O meio de cultura foi então descartado e as células lavadas duas vezes com meio de cultura sem soro. As células foram removidas dos poços com a adição de $500 \mu \mathrm{L}$ de solução de tripsina-EDTA e incubação a $3^{\circ} \mathrm{C}$ po $\mathrm{r} 2$ minutos. A tripsina foi bloqueada com a adição do mesmo volume de meio de cultura DMEM com $10 \%$ soro fetal bovino. A suspensão (meio de cultura, tripsina e células) foi centrifugada a $750 \mathrm{~g}$ por 5 minutos, e as células ressuspensas em $100 \mu \mathrm{L}$ de PBS gelado. As células foram avaliadas em citômetro de fluxo no canal FL2-H (sensível a detecções na faixa de 560 a $580 \mathrm{~nm}$ ). Os dados obtidos foram analisados utilizando o programa FlowJo $X$ 10.0.7r2. O número de eventos lidos pelo equipamento foi de 10.000 (dez mil) por amostra. 


\subsection{Análise de Fragmentação de DNA}

A fragmentação do DNA é uma característica marcante da morte por apoptose e possui um padrão característico, com fragmentos de DNA de tamanhos variáveis, mas sempre múltiplos de 180 a 200 pares de base (Saraste and Pulkki 2000). A determinação da fragmentação de DNA foi realizada de acordo com protocolo descrito por Peres \& Curi (2005). O ensaio foi realizado com $7 \times 10^{3}$ células (B16F10) e em placas de 12 poços. Após 24 horas do plaqueamento, as células foram tratadas com $1 \mathrm{~mL}$ do veneno bruto previamente esterilizado por filtração com filtros Millex-GV $0,22 \mu \mathrm{m}$, Millipore® na concentração do $I_{75}$ encontrada no ensaio anterior $(0,079 \mu \mathrm{g} / \mathrm{mL})$.

Após 24 horas, o meio de cultura contendo o veneno bruto foi retirado e armazenado em tubos de microcentrífuga e foi adicionado $500 \mu \mathrm{L}$ de tripsina para recuperação das células. As placas foram então incubadas em estufa a $3^{\circ} \mathrm{C}$ por 3 minutos. Decorrido esse tempo, a tripsina foi neutralizada com o respectivo meio de cultura que havia sido armazenado anteriormente. Em seguida, os tubos contendo as células e a tripsina foram centrifugados a $1000 \mathrm{rpm}$ por 3 minutos e 0 sobrenadante foi descartado. Na etapa seguinte, as células foram ressuspendidas em $100 \mu \mathrm{L}$ de meio de cultura DEMEN e incubadas em $200 \mu \mathrm{L}$ de tampão de lise ( $0,1 \%$ de citrato de sódio, $0,1 \%$ Triton $\mathrm{X}-100$ e $20 \mu \mathrm{g} / \mathrm{mL}$ de iodeto de propídeo (Sigma Aldrich, EUA) diluído em PBS, pH 7.4) por 30 minutos em temperatura ambiente. As amostras foram protegidas da luz durante o tempo de incubação. Em seguida, essa suspensão foi avaliada em citômetro de fluxo no canal FL2-H (sensível a detecções na faixa de 560 e $580 \mathrm{~nm}$ ). Os dados obtidos foram analisados com o programa FlowJo $X$ 10.0.7r2. O cálculo da proporção de células em cada uma das fases do ciclo celular foi realizado considerando-se apenas as células com DNA não fragmentado. A significância das proporções das médias das triplicatas foi analisada por teste t utilizando-se o software GraphPad Prism 5.03. Foi considerado estatisticamente significativo $p<0,05$. O ciclo celular foi analisado utilizando como parâmetro um total de 10.000 (dez mil) eventos por amostra. 


\subsubsection{Distribuição de células no ciclo celular}

A identificação das fases do ciclo celular avalia se a secreção bruta de $P$. nattereri induz efeitos relacionados ao bloqueio da proliferação e do ciclo celular, sendo importante, uma vez que a proliferação celular descontrolada é uma das principais características do câncer. Dessa forma, moléculas indutoras de efeitos citostáticos em células tumorais são promissoras para tratamentos terapêuticos dessa doença.

Diante disso, o teste foi realizado de acordo com protocolo descrito por Peres \& Curi (2005) sendo utilizada a concentração do $I C_{75}(0.79 \mu \mathrm{g} / \mathrm{ml})$ de secreção cutânea bruta de $P$. nattereri. O material foi avaliado em citômetro de fluxo no canal FL2-A (sensível a detecções na faixa de 560 e $580 \mathrm{~nm}$ ) para a identificação das fases do ciclo celular. Os dados obtidos foram analisados no programa FlowJo $X$ 10.0.7r2. A significância das proporções das médias das triplicatas foi analisada por teste t. utilizando-se o software GraphPad Prism 5.03. Foi considerado estatisticamente significativo $p<0,05$. $O$ ciclo celular foi analisado utilizando como parâmetro um total de 10.000 (dez mil) eventos por amostra.

\subsubsection{Análise dos efeitos da secreção bruta de $\boldsymbol{P}$. nattereri sobre o ciclo celular}

O iodeto de propídeo $(\mathrm{PI})$ é uma molécula fluorescente com propriedade de se ligar, e fixando-se ao DNA. Considerando que a intensidade de fluorescência do iodeto de propídeo depende do tamanho do DNA é possível indentificar com precisão as células nas diferentes fases do ciclo celular com a técnica de citometria de fluxo (Riccardi e Nicoletti 2006). A identificação das fases do ciclo celular foi realizada de acordo com protocolo descrito por Peres \& Curi (2005). Após o tratamento com a secreção cutânea bruta, células de melanoma murino (B16F10) foram ressuspensas em $100 \mu \mathrm{L}$ de meio de cultura e incubadas em $200 \mu \mathrm{L}$ de tampão de lise $(0,1 \%$ de citrato de sódio, $0,1 \%$ Triton $X-100$ e $20 \mu \mathrm{g} / \mathrm{mL}$ de iodeto de propídeo (Sigma Aldrich, EUA) diluído em PBS, pH 7,4) por 30 minutos em temperatura ambiente e protegidas da luz. Em seguida, essa suspensão foi avaliada no citômetro de fluxo no canal FL2-A (sensível a detecções na faixa de 560 e 580 
nm) para a identificação das fases do ciclo celular. Os dados obtidos foram analisados com o programa FlowJo X 10.0.7r2.

O cálculo da proporção de células em cada uma das fases do ciclo celular foi realizado considerando-se apenas as células com DNA não fragmentado. A significância das proporções das médias das triplicatas foi analisada por teste t. foi considerado estatisticamente significativo $p<0,05$. O ciclo celular foi analisado utilizando como parâmetro um total de 10.000 (dez mil) eventos por amostra.

\subsubsection{Apoptose versus necrose detectada com anexina-V-FITC e iodeto de propídeo (PI)}

Após o tratamento das células tumoral (B16F10) com a secreção bruta de P. nattereri previamente esterilizado por filtração com filtros Millex-GV $0,22 \mu \mathrm{m}$, Millipore $\AA$, as células serão lavadas com PBS e ressuspensas em $100 \mu \mathrm{L}$ de tampão de ligação [10 mM HEPES/ $\mathrm{NaOH}(\mathrm{pH} 7,4), 140 \mathrm{mM} \mathrm{NaCl}, 2,5 \mathrm{mM} \mathrm{CaCl}$ ]. Foram adicionados $5 \mu \mathrm{L}$ de Anexina V-FITC (BD Pharmingen ${ }^{\mathrm{TM}}$, USA) e $10 \mu \mathrm{L}$ de iodeto de propídeo (PI) (Sigma Aldrich, EUA) e incubadas por 15 minutos, protegido da luz, a temperatura ambiente. Finalmente, $400 \mu \mathrm{l}$ de tampão de ligação foram adicionadas e as células foram imediatamente analisadas por citometria de fluxo FACSCalibur (Becton \& Dickenson, USA). Um total de 10.000 eventos foi analisado por amostra.

\subsubsection{Potencial de membrana mitocondrial}

A rodamina 123 é uma molécula fluorescente catiônica permeável à membrana plasmática e rapidamente seqüestrada por mitocôndrias com potencial de membrana normalizado. Alterações no potencial de membrana da mitocôndria desencadeiam um efluxo da rodamina 123 da mitocôndria (Chen et al., 1982). A determinação do potencial de membrana mitocondrial foi realizada de acordo com protocolo já descrito (Peres et al., 2005). Após o tratamento com a secreção cutânea bruta de $P$. nattereri, previamente esterilizada por filtração com filtros Millex-GV $0,22 \mu \mathrm{m}$, Millipore $\AA$, a célula tumoral de melanoma murino (B16F10) foram ressuspensas em $100 \mu \mathrm{L}$ de meio de cultura e lavadas com $500 \mu \mathrm{L}$ de PBS. Em 
seguida, as células foram ressuspensas em $500 \mu \mathrm{L}$ de PBS e incubadas preotegidas da luz, com $0,5 \mu \mathrm{L}$ de solução de rodamina $123(5 \mathrm{mg} / \mathrm{mL}$ diluídos em etanol, Sigma, EUA) foram adicionadas a cada grupo de células e incubou-se durante 15 minutos à temperatura ambiente. Em seguida a incubação, as células foram lavadas 2 vezes com PBS. Por fim, foram incubadas com $300 \mu \mathrm{L}$ de PBS por 30 minutos (temperatura ambiente e protegida da luz) e avaliadas em citômetro de fluxo no canal FL1-H (sensível a deteç̧ões na faixa de 515 a $530 \mathrm{~nm}$ ). Os dados obtidos foram analisados no programa FlowJo $X$ 10.0.7r2. Todas as etapas de lavagem foram seguidas por centrifugação (750 g por 3 minutos) e descarte do sobrenadante. A significância das proporções das médias das triplicatas foi analisada por teste t. Foi considerado estatisticamente significativo $p<0,05$. Um total de 10.000 (dez mil) eventos foi lido por amostra.

\subsubsection{Análise estatística}

As diferenças estatísticas entre o controle e as células tratadas foi avaliado através do teste $t$ de Student não pareado, com nível de significância de 0,05, utilizando o programa software GraphPad Prism 5.03 (GraphPad Software). Todos os valores foram expressos como médias $\pm \mathrm{DP}$, (desvio padrão) correspondente à análise de três experimentos diferentes em cada grupo. Os valores significativamente diferentes do controle, $p<0,05$ são indicados nas figuras com asteriscos. Todos os experimentos foram realizados em triplicata. 


\section{Segunda Etapa: Identificação e caracterização biológica de peptídeos antimicrobianos e anticâncer presentes na secreção de Physalaemus nattereri}

\subsection{Reagentes Químicos}

Todos os experimentos foram realizados com reagentes comerciais de grau analítico utilizando apenas água ultrapura tipo 1 (Milli- $Q^{\circledR}$, Merck Millipore, USA) para o preparo das soluções. Os solventes utilizados nas etapas cromatográficas foram todos grau HPLC, de diversos fornecedores.

\subsection{Coleta dos animais e obtenção da secreção cutânea de $P$.}

\section{nattereri}

Adultos de Physalaemus nattereri foram coletados no município de Monte Alegre/GO. A secreção cutânea foi obtida por estimulação elétrica $(110 \mathrm{~V}, 60 \mathrm{~Hz}$, corrente alternada). Os animais foram lavados com água Milli-Q, e o material coletado foi então liofilizado. A amostra após estar seca foi aliquotada em frações de $5,0 \mathrm{mg}$ e armazenada a $-20{ }^{\circ} \mathrm{C}$ até o uso. O procedimento não ocasionou dano ou morte de nenhum animal, reassumindo seu comportamento normal após a estimulação elétrica.

\subsubsection{Fracionamento cromatográfico da secreção cutânea de P. nattereri}

Alíquotas $(5,0 \mathrm{mg})$ da secreção cutânea bruta após liofilizada, de Physalaemus nattereri foi individualmente dissolvidas em $200 \mathrm{~mL}$ de TFA $0,1 \%$ (v/v) em água, centrifugadas a $12.000 \mathrm{~g}$ por $15 \mathrm{~min}$ e aplicadas em colunas de fase reversa C18 (Shim-pack CLC-ODS, 6.0 x $150 \mathrm{~mm}$ ). A eluição foi realizada empregando-se fluxo de $1 \mathrm{~mL} / \mathrm{min}$. Primeiramente, a coluna foi lavada por $5 \mathrm{~min}$ com $0,1 \%(\mathrm{v} / \mathrm{v})$ de TFA/água (solvente A) e, em seguida, foi aplicado gradiente linear de 0-60\% por 60 min e de $60-100 \%$ de acetonitrila contendo $0,1 \%$ de TFA (solvente B) por $5 \mathrm{~min}$, seguido de uma lavagem de $5 \mathrm{~min}$ com $100 \%$ de solvente B. 
A absorbância foi monitorada a $216 \mathrm{~nm}$ e as frações foram manualmente coletadas, secadas a vácuo e armazenadas a $-20^{\circ} \mathrm{C}$. Todas as fra ções eluídas foram testadas para avaliação da sua capacidade de inibir a proliferação de bactérias e fungos patogênicos e células de melanoma, assim como quanto à capacidade de promover a lise de eritrócitos, como descrito nas seções 4.10.4, 4.10.5, 4.10.6 e 4.10.7.

\subsubsection{Purificação dos peptídeos bioativos presentes na secreção de $P$. nattereri}

As frações que apresentam efeitos inibitórios sobre a proliferação de bactérias e células de melanoma foram recromatografadas por RP-HPLC injetando-se a amostra dissolvida em TFA $0,1 \%(\mathrm{v} / \mathrm{v})$ em água em uma coluna $\mathrm{C}_{18}$ de fase reversa (Vydac 218TP54, 4,6 × $250 \mathrm{~mm}$ ) e a eluição foi realizada empregando-se fluxo de $1 \mathrm{~mL} / \mathrm{min}$. previamente equilibrada com o mesmo solvente. A eluição foi feita com aplicação de gradientes lineares de acetonitrila, com detecção UV em $216 \mathrm{~nm}$. As frações eluídas foram coletadas manualmente, secadas a vácuo e armazenadas a $-20 \stackrel{\circ}{ } \mathrm{C}$. A homogeneidade das frações obtidas foi avaliada por espectrometria de massas tipo MALDI-TOF e quando necessário as frações foram submetidas a novos passos cromatográficos empregando-se a mesma coluna.

\subsubsection{Análise por espectrometria de massas do tipo MALDI-TOF}

Todas as frações peptídicas foram caracterizadas com relação a sua composição peptídica/protéica por meio da determinação das massas moleculares experimentais das frações cromatográficas em espectrômetro de massa MALDI-TOF/TOF Autoflex II (Bruker Daltonics, Bremen, Germany).

As frações foram dissolvidas em $0,1 \%(\mathrm{v} / \mathrm{v})$ de TFA/água e $1 \mu \mathrm{L}$ de cada fração aplicado em placa de aço inoxidável juntamente com $1 \mu \mathrm{L}$ da matriz reconstituída de ácido a-ciano-4-hidroxicinâmico (HCCA $20 \mu \mathrm{g} / \mu \mathrm{L}$ ) ou ácido 3,5-dimetoxi-4-hidroxicinâmico (ácido sinapínico - AS $20 \mu \mathrm{g} / \mu \mathrm{L}$ ) ressuspendidas em $50 \%(\mathrm{v} / \mathrm{v})$ acetonitrila/0,1\% (v/v) TFA. Dois tipos de análises foram realizadas com cada fração cromatográfica plaqueada: modo refletor de íons positivos e linear. 
O procedimento realizado no modo refletor utilizou a solução Peptide Mix (Brucker Daltonics) para a calibração e matriz HCCA, sendo a faixa $\mathrm{m} / \mathrm{z}$ analisada de 500 a 4000 Da. Os peptídeos recromatografados foram submetidos ao mesmo procedimento descrito acima para a verificação do grau de pureza antes da realização dos ensaios de atividade biológica.

\subsubsection{Ensaios hemolíticos}

Eritrócitos de sangue humano $\mathrm{O}^{+}$obtidos no Hemocentro de Brasília após realização de exames sorológicos, foram separados do plasma por sedimentação e

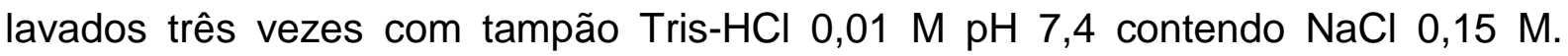
Foi empregado o mesmo tampão para preparar uma suspensão $1 \%(\mathrm{v} / \mathrm{v})$ de hemáceas e também para solubilizar as amostras. Em tubos de 1,5 mL, $100 \mu \mathrm{L}$ da suspensão de hemáceas foram incubadas com $100 \mu \mathrm{L}$ de amostra por $60 \mathrm{~min}$, à temperatura ambiente. Também foram incubados com $100 \mu \mathrm{L}$ da suspensão de hemáceas, $100 \mu \mathrm{L}$ de Triton X-100 1\% (v/v), constituindo a referência para 100\% de hemólise, e $100 \mu \mathrm{L}$ do tampão Tris, referência para $0 \%$. Após a incubação, os tubos foram centrifugados a $3000 \mathrm{~g}$ por $2 \mathrm{~min}$. Alíquotas de $100 \mathrm{~mL}$ dos sobrenadantes de cada fração cromatográfica foram transferidas para placas de microtitulação de 96 poços de fundo chato (TPP), e a leitura da absorbância realizada a $405 \mathrm{~nm}$ (leitora Multiskan® FC, Thermo Scientific, USA). Para as amostras de referência utilizaramse $100 \mu \mathrm{L}$ da suspensão de eritrócitos a $1 \%$ (v/v) incubada com $100 \mu \mathrm{L}$ de Triton X-100 1\% (v/v) como referência de $100 \%$ de lise e $100 \mu \mathrm{L}$ da suspensão de eritrócitos a $1 \%(\mathrm{v} / \mathrm{v})$ com tampão salina como referência de $0 \%$ de hemólise. A quantidade de hemólise foi avaliada utilizando-se a seguinte fórmula (Oguiura et al., 2011):

$$
\frac{A_{405 \text { peptídeo }}-A_{405 \text { tampão }}}{A_{405 \text { Tritón }}-A_{405 \text { tampão }}} * 100
$$

Com a finalidade de verificar se os componentes da secreção cutânea de $P$. nattereri exibiam atividade hemolítica, cada fração de uma corrida cromotagráfica 
foi solubilizada em solução Tris-salina e incubada com a suspensão de hemáceas, de acordo com o método descrito acima.

\subsubsection{Ensaios antibacterianos}

Linhagens referenciais de bactérias, obtidas do Banco de Culturas Tropicais da Fundação André Tosello (Campinas, SP), foram cultivadas em $7 \mathrm{~mL}$ de meio Mueller-Hinton, sob agitação a $37^{\circ} \mathrm{C}$. Quando a dens idade ótica em $590 \mathrm{~nm}$ atingiu o valor de 1,0, cada suspensão bacteriana inicial foi diluída em meio Mueller-Hinton fresco, nas proporções de 1:50 para bactérias Gram-negativas e 1:100 para Gram-positivas. Uma alíquota de $50 \mu \mathrm{L}$ de cada cultura bacteriana (contendo de $2 \mathrm{a}$ $5 \times 10^{5}$ CFUs dependendo da linhagem bacteriana empregada) foi incubada por 22 horas a $3^{\circ} \mathrm{C}$ com $50 \mu \mathrm{L}$ de amostra ressuspendida em água Milli-Q estéril, numa proporção de 1:1 (v/v), em placas de microtitulação estéreis (96 poços, fundo chato). Como controle representativo da ausência de proliferação bacteriana, foi realizada a incubação de formaldeído $0,4 \%$ (v/v) com a suspensão bacteriana e como controle representativo da proliferação máxima, foi feita a incubação da suspensão bacteriana com água Milli-Q estéril. Após a incubação por um período de 22 horas, a $37^{\circ} \mathrm{C}$, as placas foram analisadas a $595 \mathrm{~nm}$ na leito ra de placa (Multiskan®) FC, Thermo Scientific, USA).

\subsubsection{Ensaios preliminares}

Para verificar a atividade das frações peptídicas contra microrganismos, foi realizado um ensaio antimicrobiano inicial em placa multi-poços contra as bactérias patogênicas Gram-negativa Enterobacter cloacae (ATCC 35030), e a Gram-positiva Staphylococcus aureus (ATCC 25923). O screening foi realizado a fim de verificar quais componentes da secreção cutânea de $P$. nattereri obtidos após fracionamento cromatográfico apresentavam atividade inibitória sobre a proliferação bacteriana. Cada fração cromatográfica de uma corrida de RP-HPLC foi solubilizada em água Milli-Q e incubada com a respectiva suspensão bacteriana, de acordo com o método descrito. Após 22 horas de incubação a $37^{\circ} \mathrm{C}$, as pl acas foram analisadas em 595 nm por meio da leitora de placa (Multiskan® FC, Thermo Scientific, USA). 


\subsubsection{Ensaios com leveduras}

Cepas de Candida albicans (ATCC 14053) e Cryptococcus neoformans (ATCC 32045) cedidas pelo Laboratório de Micologia do LACEN - DF, foram cultivadas em Ágar Sabouraud dextrose (MicroMed), sendo executadas passagens (repiques) para assegurar sua pureza e viabilidade. $\mathrm{O}$ inoculo foi preparado a partir de colônias de $C$. albicans e $C$. neoformans crescidas em ágar Sabouraud após 24 horas em $35^{\circ} \mathrm{C}$, as quais foram suspensas em caldo $\mathrm{BHI}$ (Brain Heart Infusion, HIMEDIA). As cepas foram cultivadas em $5 \mathrm{~mL}$ de meio $\mathrm{BH}$ fresco sob agitação a $3^{\circ} \mathrm{C}$ até a densidade óptica igual a $1 \mathrm{em} 595 \mathrm{~nm}$. As leveduras, em fase logarítimica, foram diluídas no mesmo meio de cultura na proporção 1:100. Uma alíquota de $50 \mu \mathrm{L}$ desta suspensão de levedura a 1:100 (contendo aproximadamente $2 \times 10^{3} \mathrm{CFUs}$ ) foi incubada por $22 \mathrm{~h}$ a $35^{\circ} \mathrm{C}$ com $50 \mu \mathrm{L}$ de amostra (frações da secreção cutânea de $P$. nattereri provenientes de uma corrida cromatográfica) ressuspendidos em água Milli-Q estéril, em placas de microtitulação estéreis (96 poços, fundo chato).

Os controles para ausência de crescimento e crescimento pleno foram, respectivamente, formaldeído $0,4 \%$ ( $/ / v)$ e água Milli-Q estéril ambos incubados com as suspensões das leveduras. A concentração final do inóculo nos poços contendo $100 \mu \mathrm{L}$ da suspensão de células foi de aproximadamente $2 \times 10^{4}$ por mL. Após a inoculação, as placas foram incubadas a $3^{\circ} \mathrm{C}$, com l eitura de absorbância em 595 nm após 24 e 48 horas em leitora de placas (Multiskan® FC, Thermo Scientific, USA).

\subsection{Tratamento das células tumorais com os peptídeos}

Ao atingir o estágio de confluência, as células de câncer (células HeLa e B16F10) e fibroblastos normais (NIH-3T3) foram removidas do frasco de cultura e centrifugadas como descrito anteriormente. O sobrenadante foi descartado e as células ressuspensas em $1 \mathrm{~mL}$ de meio de cultura. Para a determinação do número de células, $10 \mu \mathrm{L}$ da suspensão de células foi adicionado a $40 \mu \mathrm{L}$ de solução de azul tripan $(0,4 \%$ diluídos em PBS, $\mathrm{p} / \mathrm{v})$. Uma alíquota de $8 \mu \mathrm{L}$ dessa mistura foi depositada vagarosamente em uma câmara de Neubauer, onde células presentes 
nos quatro quadrantes maiores laterais foram contadas em microscópio de luz. O número de células foi determinado pela seguinte fórmula:

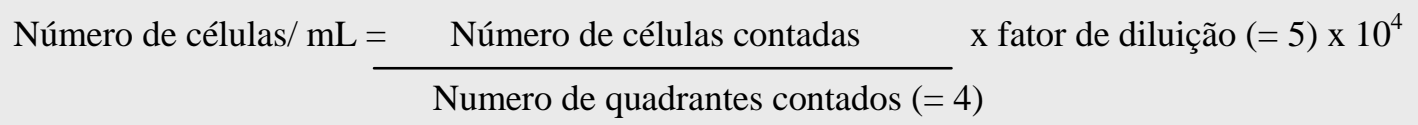

As células contadas foram transferidas para placas de cultura e incubadas em estufa a $37^{\circ} \mathrm{C}$ e $5 \%$ de $\mathrm{CO}_{2}$, por 24 horas, para a completa adesão das células no fundo da placa. As células foram transferidas para placas de tamanhos diferentes, dependendo do experimento a ser realizado. Placas de 96 poços foram utilizadas para ensaios de viabilidade celular por MTT (ver descrição abaixo), com concentração inicial de $5 \times 10^{3}$ células/poço. Após o período de incubação na estufa, as placas de cultura foram observadas em microscópio de luz invertido para a avaliação da morfologia, dispersão das células pela placa e presença de contaminação.

Essa análise foi realizada para decidir se as células estavam homogeneamente dispersas e saudáveis para serem submetidas aos ensaios com os peptídeos de interesse produzidos por síntese química.

Com a finalidade de verificar se os componentes da secreção cutânea de P. nattereri exibiam atividade anticâncer, foi empregada a linhagem B16F10 e cada fração de uma corrida cromotagráfica foi solubilizada em meio DMEM.

No caso dos peptídeos purificados, o meio de cultura contendo os peptídeos de interesse foi preparado a partir da diluição seriada das soluções estoque dessas moléculas $(128 \mu \mathrm{M})$ em meio de cultura. O meio de cultura do grupo controle (ausência dos peptídeos de interesse) continha apenas meio DMEM na mesma proporção que foi adicionada aos outros grupos experimentais. O meio de cultura das placas foi substituído pelo que continha os peptídeos. As placas foram incubadas em estufa a $37^{\circ} \mathrm{C}$ e $5 \%$ de $\mathrm{CO}_{2}$, por 24 horas. Após o período de incubação, as células foram preparadas de maneira adequada para a realização dos testes. Todos os experimentos foram realizados em triplicata. 


\subsection{Avaliação da viabilidade celular empregando-se $o$ método do MTT}

A viabilidade celular foi avaliada pelo método de MTT estabelecido por Mosmann (1983). As células tumorais (HeLa e B16F10) e as células normais (fibroblastos da linhagem NIH-3T3) foram cultivadas e tratadas com as frações da secreção cutânea de $P$. nattereri provenientes de uma corrida cromatográfica e com os peptídeos purificados em placas de 96 poços, como descrito no item acima. Após o período de incubação de 24 horas, o meio de cultura das placas foi removido, e $150 \mu \mathrm{L}$ de solução de uso de MTT (15 $\mu \mathrm{L}$ de MTT $5 \mathrm{mg} / \mathrm{mL}$ diluídos em $135 \mu \mathrm{L}$ de DMEM completo) foram adicionados em cada poço. As células foram incubadas por 3 horas em estufa a $37^{\circ} \mathrm{C}$ e $5 \%$ de $\mathrm{CO}_{2}$. Em seguida, o meio de cultura foi removido e $100 \mu \mathrm{L}$ de DMSO foram adicionados em cada poço para dissolver o formazan formado. A quantificação do formazan foi feita pela medida da absorbância dos poços no comprimento de onda de $595 \mathrm{~nm}$, em espectrofotômetro conjugado a uma leitora de microplacas (Multiskan® FC, Thermo Scientific, USA).

A viabilidade celular foi determinada pela média da triplicata de cada concentração testada. A partir dos dados obtidos foi elaborada uma curva de inhibição e calculados os valores de $I_{50}$ e $I_{75}$ (concentração que produz uma resposta inibitória de 50 e $75 \%$, respectivamente) com emprego do software Prism versão 5.03 (Graphpad Software).

\subsection{Síntese química dos peptídeos isolados da secreção bruta de $P$. nattereri}

Os peptídeos empregados no presente estudo foram obtidos por meio da síntese química manual, segundo o protocolo de Atherton \& Sheppard (1989), com a colaboração do Prof. Eduardo Cilli (UNESP - Araraquara). Utilizaram-se os seguintes grupos de proteção da cadeia lateral: Boc (tbutoxicarbonil) para K; tBut (t-butil) para D, T e E e Pmc (2,2,5,7,8 pentametilchromane- 6-sulfonil) para Q e N. Cada ciclo de síntese consistiu na desproteção de Na-Fmoc com piperidina/dimetilformamida $20 \%$ (v/v) durante $20 \mathrm{~min}$, seguido por lavagem com diclorometano e dimetilformamida e acoplamento ao próximo resíduo. Ao final da síntese, a clivagem do peptídeo foi 
realizada em um coquetel contendo água ultra-pura 5\% (v/v); fenol 5\% (v/v); 1,2 etanoditiol 2,5\% (v/v) e tioanisol $5 \%(\mathrm{v} / \mathrm{v})$ em TFA, por $2 \mathrm{~h}$, sob agitação. $\mathrm{O}$ peptídeo foi então precipitado com éter etílico gelado e filtrado em placa porosa juntamente com a resina. O peptídeo, retido na placa, foi dissolvido em solução aquosa de ácido acético $10 \%(\mathrm{v} / \mathrm{v})$ e separado da resina por filtração. O filtrado foi liofilizado, solubilizado em TFA $0,045 \%$ (v/v) em água (solvente A) e purificado por RP-HPLC, utilizando-se coluna semi-preparativa (Beckman $\mathrm{C}_{18} 1 \mathrm{~cm} \times 25 \mathrm{~cm}$ ), gradiente linear de 10 a $40 \%$ de TFA 0,036\% (v/v) em acetonitrila (solvente B) durante $90 \mathrm{~min}$, detecção em $220 \mathrm{~nm}$ e fluxo de $5 \mathrm{~mL} / \mathrm{min}$. As impurezas derivadas do processo de síntese foram retiradas por meio de RP-HPLC em coluna $\mathrm{C}_{18}$ (Vydac 218TP54, 4,6 x $250 \mathrm{~mm}$ ).

As identidades dos peptídeos sintéticos foram confirmadas por espectrometria de massas do tipo MALDI-TOF/TOF (Bruker, Autoflex II). 
Avaliação dos efeitos citotóxicos e antiproliferativos da secreção cutânea e de peptídeos bioativos do anuro Physalaemus nattereri (Steindachner, 1863)

5. Resultados 


\section{Resultados}

* Primeira etapa: Avaliação os efeitos citotóxicos e antiproliferativos da secreção cutânea do anuro Physalaemus nattereri sobre células de melanoma in vitro

\subsection{Avaliação preliminar dos efeitos citotóxicos e antiproliferativos da secreção cutânea bruta de $P$. nattereri sobre células tumorais das linhagens B16F10 e HeLa}

A análise das figuras 13 e 14 permite constatar que a secreção bruta de $P$. nattereri exibiu efeitos antiproliferativos de forma dose-dependente Os resultados revelam que as células de melanoma são cerca de 4,4 vezes mais susceptíveis aos efetios deletérios da secreção de $P$. nattereri do que os fibroblastos normais com $\mathrm{IC}_{50}$ iguais a $0,51 \mu \mathrm{g} / \mathrm{mL}$ e $2,23 \mu \mathrm{g} / \mathrm{mL}$ respectivamente.

No caso do tratamento da linhagem tumoral HeLa com a secreção bruta de $P$. nattereri pode-se observar claramente seus efeitos deletérios sobre a viabilidade celular (Figura 15). Para fins de comparação dos efeitos citotóxicos sobre as células tumorais, a secreção bruta também foi incubada com células de fibroblastos normais (NHI-3T3) por 24 horas. (Figura 13). O valor do IC I0 $_{50}$ calculado após a incubação de células HeLa e de fibroblastos com a secreção bruta de $P$. nattereri foi igual a $23,04 \mu \mathrm{g} / \mathrm{mL}$ e 2,23 $\mu \mathrm{g} / \mathrm{mL}$. Como pode ser constato, a secreção bruta de $P$. nattereri apresentou efeitos citotóxicos significativos sobre ambas as linhagens celulares, sendo que exibiu maior potência sobre as células normais. 


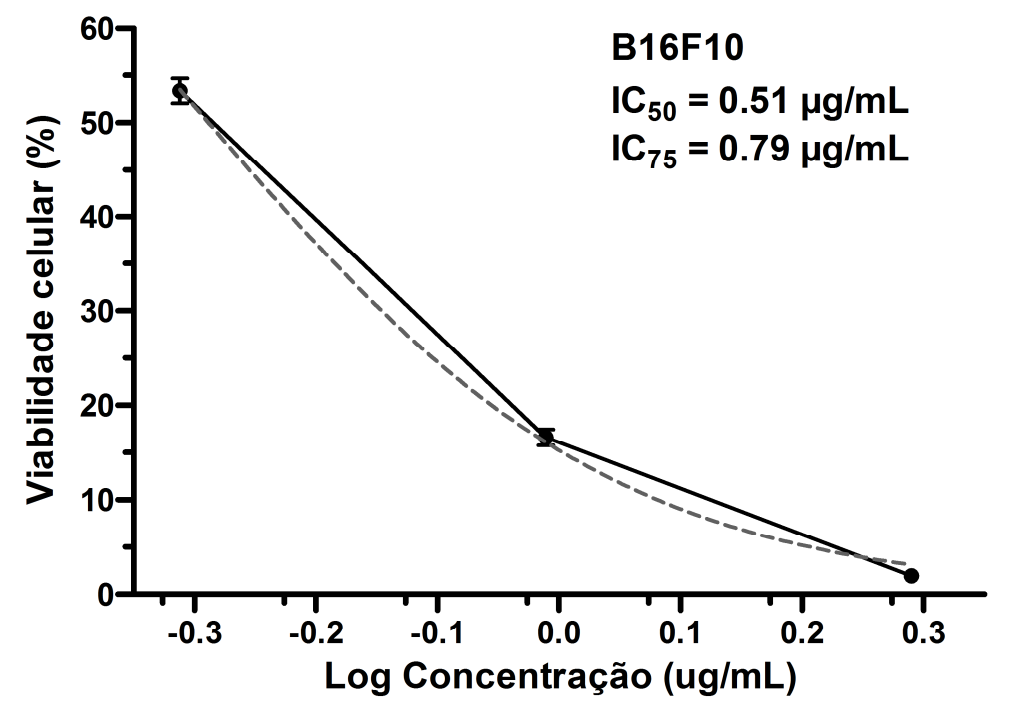

Figura 13. Efeitos da secreção cutânea bruta de $P$. nattereri sobre a taxa de viabilidade celular de células de melanoma murino (B16F10). O tratamento foi realizado com a incubação por $24 \mathrm{~h}$ das células com concentrações crescentes da secreção bruta de $P$. nattereri. A viabilidade celular foi determinada pelo ensaio do MTT. Os dados estão expressos em média \pm SD (desvio padrão) de experimentos realizados em triplicata. ${ }^{*} p<0,01$ comparado com o grupo controle.

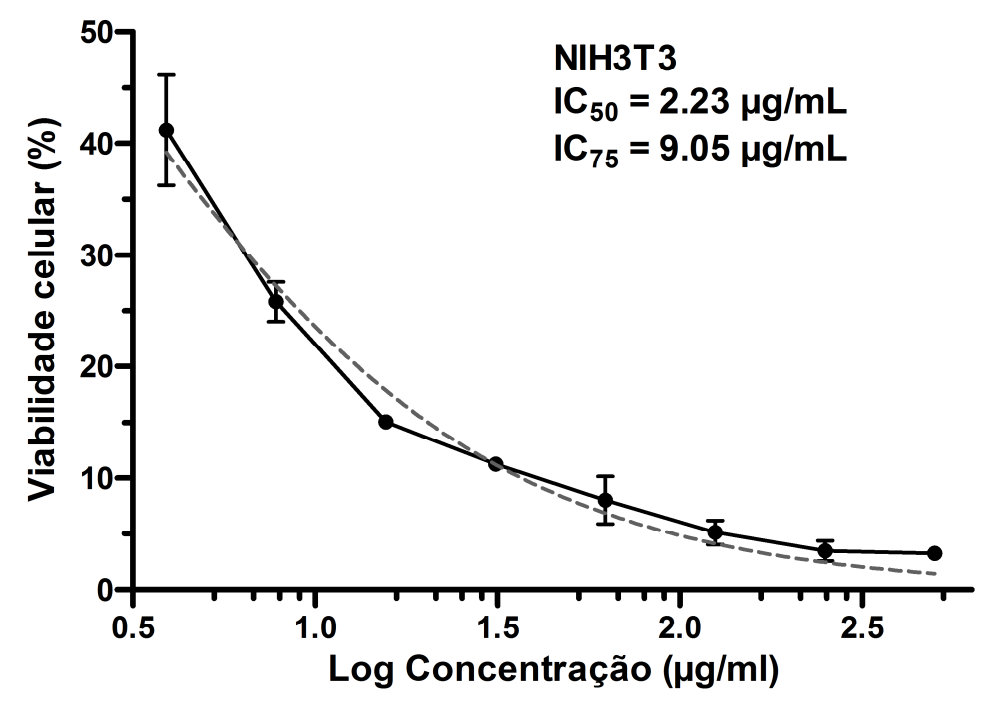

Figura 14. Efeitos da secreção cutânea bruta de $P$. nattereri sobre a taxa de viabilidade celular de fibroblastos normais (NIH-3T3). O tratamento foi realizado com a incubação por $24 \mathrm{~h}$ das células com concentrações crescentes da secreção bruta de $P$. nattereri. A viabilidade celular foi determinada pelo ensaio do MTT. Os dados estão expressos em média \pm SD (desvio padrão) de experimentos realizados em triplicata. ${ }^{*} p<0,01$ comparado com o grupo controle. 
Ao se comparar os efeitos deletérios provocados pela incubação da secreção bruta de $P$. nattereri sobre as duas linhagens tumorais testadas, observa-se claramente uma maior susceptiblidade das células de melanoma murino (Figura 15).

Analisando-se os valores determinados para os $\mathrm{IC}_{50}$ referentes as duas linhagens, pode-se constatar que as células HeLa (com IC $\mathrm{I}_{50}=23,4 \mu \mathrm{g} / \mathrm{mL}$ ) exibiram uma resistência cerca de 46 vezes superior em comparação com as células da linhagem B16F10 (com IC $50=0,51 \mu \mathrm{g} / \mathrm{mL})$.

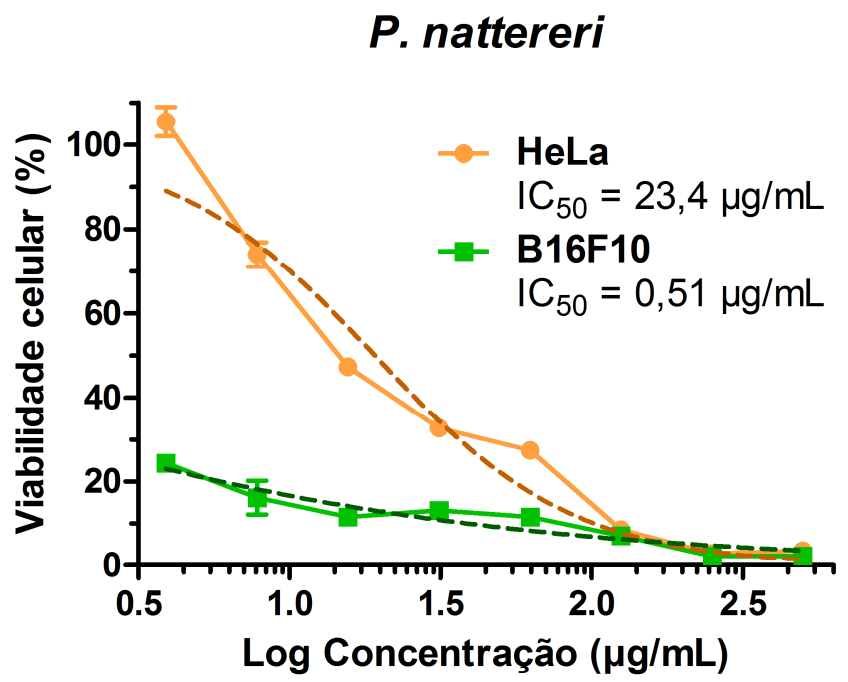

Figura 15. Comparação dos efeitos da secreção cutânea bruta de $P$. nattereri sobre as taxas de viabilidade celular de células de melanoma murino (B16F10) e de células de câncer de colo uterino (HeLa). O tratamento foi realizado com a incubação por $24 \mathrm{~h}$ das células com concentrações crescentes $(3,9-500 \mu \mathrm{g} / \mathrm{mL})$ da secreção bruta de $P$. nattereri. A viabilidade celular foi determinada pelo ensaio do MTT. Os dados estão expressos em média \pm SD (desvio padrão) de experimentos realizados em triplicata.

Os resultados acerca da viabilidade celular dos diferentes tipos celulares empregados após incubação com a secreção cutânea bruta do anuro $P$. nattereri mostra claramente que a linhagem tumoral B16F10 é a mais suscetível aos efeitos antiproliferativos desse veneno. Sendo assim, tal linhagem celular foi selecionada para a realização dos ensaios biológicos subsequentes com o intuito de se entender o mecanismo de ação dos componentes presentes na secreção bruta de $P$. nattereri sobre as células de melanoma murino. 


\subsection{Efeitos da secreção cutânea bruta de $P$. nattereri sobre a morfologia celular}

Os efeitos da secreção cutânea bruta de $P$. natteri sobre a morfologia das células da linhagem B16F10 foram avaliados após 24 horas de incubação e foi possível observar alterações morfológicas bem definidas nas células (Figura 16).

Foram constatadas alterações expressivas em células de melanoma murino na presença do veneno bruto se comparadas com as células na ausência do veneno bruto. Dentre essas modificações, foram observadas principalmente alterações como a perda dos prolongamentos celulares, perda da integridade da membrana, alteração na morfologia celular, e arrendondamento das células.

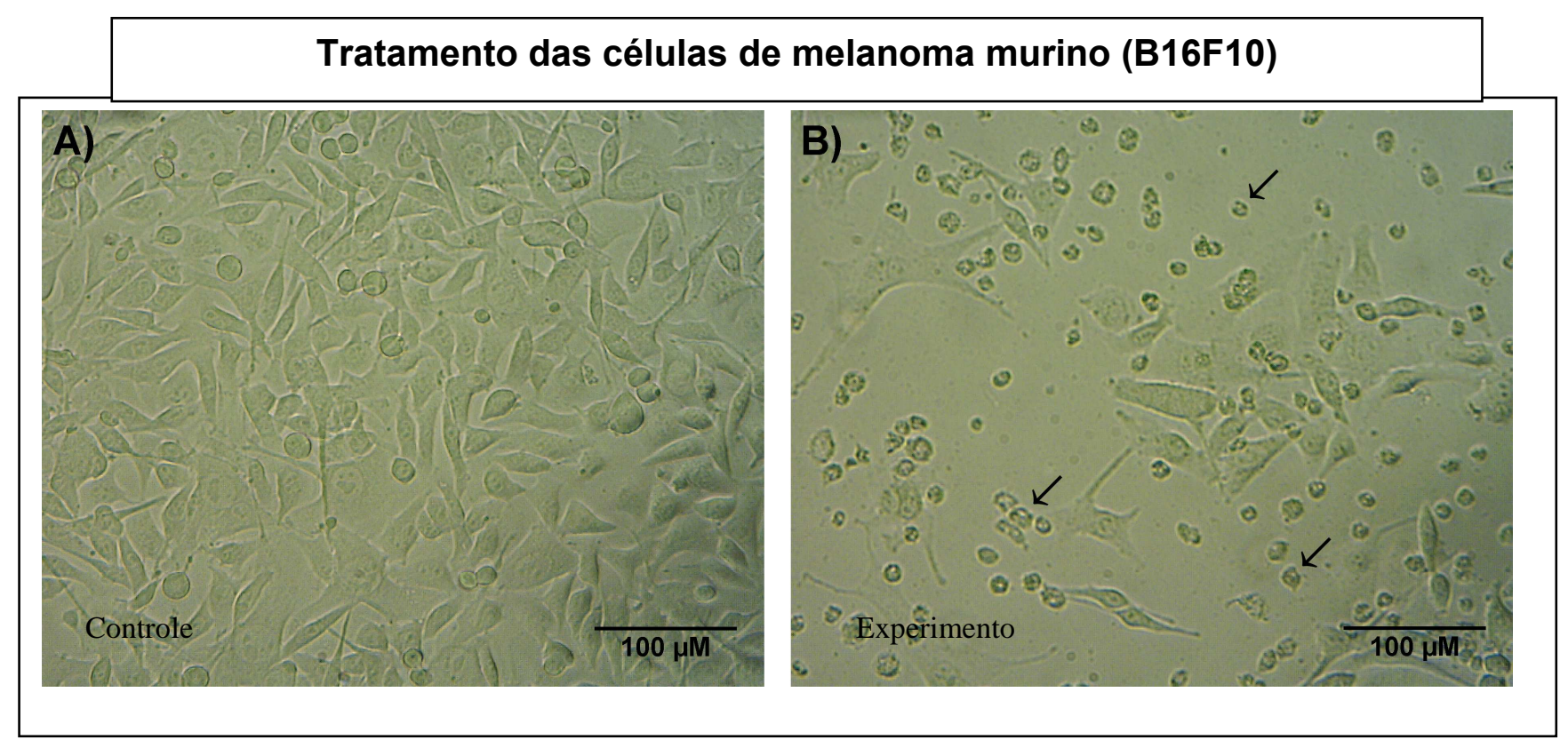

Figura 16. Fotomicrografias de células de melanoma murino (B16F10) da esquerda para a direita o grupo controle (ausência da secreção cutânea bruta) e após o tratamento (presença da secreção bruta de $P$. nattereri). $\mathrm{O}$ tratamento foi realizado empregando-se a concentração de $0,79 \mu \mathrm{g} / \mathrm{mL}$, (equivalente ao $\mathrm{IC}_{75}$ para as células $\mathrm{B} 16 \mathrm{~F} 10$ ) com incubação por 24 horas. Pode-se observar no grupo controle a conservação da morfologia celular, observando inclusive uma morfologia celular definida, e membrana citoplasmática integra. No entanto, nas células de melanoma murino quando tratadas com o veneno, observa-se perda da integridade da membrana plasmática e alteração da morfologia celular, apresentando-se de forma arrendondada (setas). Imagens obtidas por microscópio de contraste de fase invertido (Zeiss, Alemanha) com o uso de câmera digital acoplada a ocular do microscópio e o software de aquisição DinoCapture 2.0 Version 1.5.0. Barra $=100 \mu \mathrm{m}$. 


\subsection{Efeitos da secreção cutânea bruta de $P$. nattereri sobre a} granulosidade e tamanho das células de melanoma murino (B16F10)

A partir de experimentos utilizando a técnica de citometria de fluxo, foi possível avaliar o tamanho da célula (FSC-H) e também a granulosidade (SSC-H) após o tratamento das células de melanoma murino com a secreção bruta de $P$. nattereri. Foi observado que o tratamento com a secreção cutânea bruta induz pequenas alterações nos parâmetros que indicam uma tendência geral para a diminuição do tamanho das células (Figura 17A (Q1) e Figura 17B, $p<0,01$ ). Além disso, foi observado um aumento discreto na granulosidade de células, como mostrado nas figuras 17A (Q4) e figura 17B $(p<0,05)$.
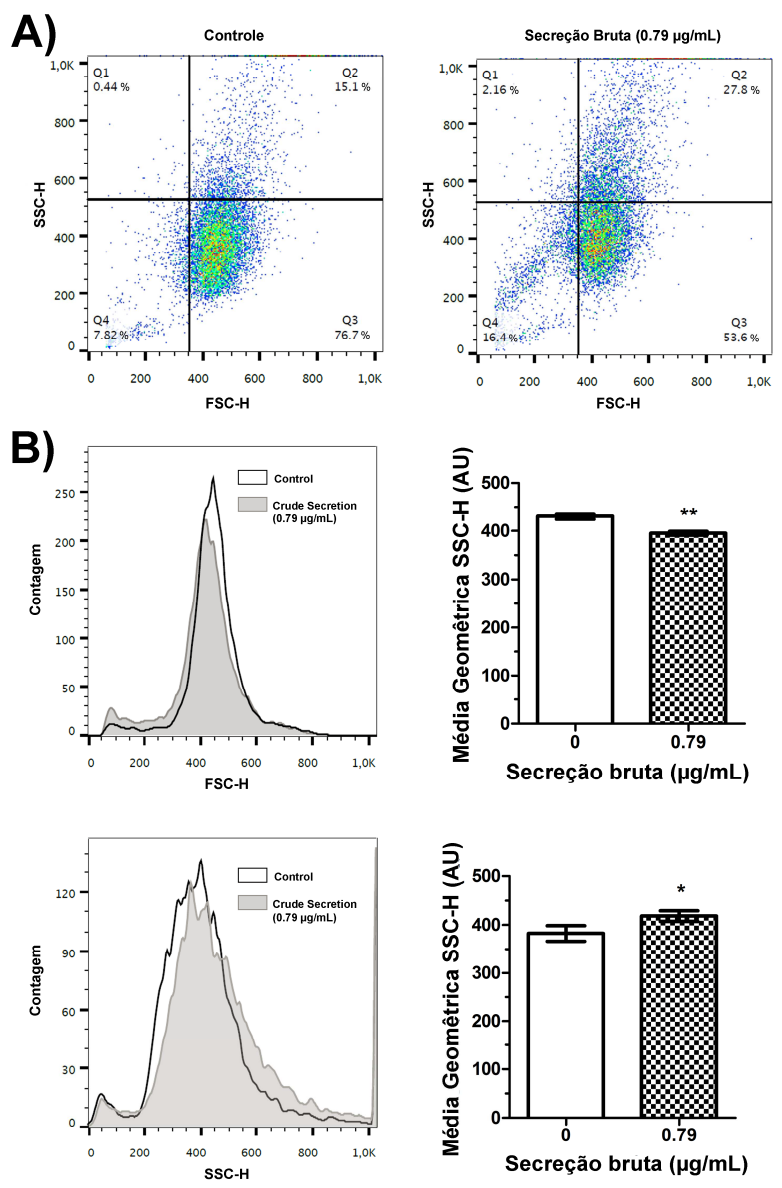

Figura 17. Efeitos sobre a morfologia celular avaliados por citometria de fluxo em células B16F10 tratadas por $24 \mathrm{~h} \mathrm{(}>0,05, \mathrm{n}=3$ ) com (A) $0 \mu \mathrm{g} / \mathrm{mL}$ (controle) e (B) $0,79 \mu \mathrm{g} / \mathrm{mL}\left(\right.$ IC $\left._{75}\right)$ de secreção bruta de $P$. nattereri . Total de eventos: 10.000 . (dez mil) Legenda: ${ }^{*}=p<0,05 e^{* \star}=p<0,01$. 


\subsection{Efeitos da secreção cutânea bruta de $P$. nattereri sobre a membrana plasmática das células de melanoma murino (B16F10)}

Com o intuito de se avaliar as possíveis alterações na membrana plasmática que o tratamento com a secreção bruta do anuro $P$. nattereri é capaz de promover sobre as células de melanoma murino B16F10, foram realizados ensaios empregando-se citometria de fluxo, com a marcação das células com anexina-V e iodeto de propídeo $(\mathrm{PI})$. A figura 18 exibe o resultado do tratamento das células de melanoma com a concentração de $0,79 \mu \mathrm{g} / \mathrm{mL}$ de secreção bruta de $P$. nattereri por $24 \mathrm{~h}$. Pode-se novamente observar alterações nas células induzidas pela presença do veneno de $P$. nattereri ao considerarmos os padrões de exposição de fosfatidilserina (revelado pela marcação com anexina- $V$ ) e a permeabilidade da membrana plasmática (revelado com iodeto de propídeo). Nesse caso, foi observado um aumento de $4,23 \%$ no número de células marcadas com anexina-V e PI após o tratamento $(1,31 \pm 0,50 \%$ versus $5,54 \pm 0,66 \%, p<0,001)$.

Alem disso, houve um aumento de $41,26 \%$ no número de células marcadas apenas com anexina- $V(2,05 \pm 0,73 \%$ versus $43,31 \pm 10,02 \% ; p<0,001)$; e, consequentemente, uma diminuição de $38,48 \%(94,01 \pm 1,20 \%$ versus $54,53 \pm$ $10,77 \% ; p<0,01)$ no número de células não marcadas. Cabe ressaltar que não foram observadas diferenças significativas no número de células marcadas exclusivamente com iodeto de propídeo $(0,14 \pm 0,49$ versus. $0,11 \pm 0,31 ; p>0,05)$.

Em relação ao controle (células não-tratadas) foi verificado que a membrana plasmática não apresentou exposição de fosfatidilserina de forma expressiva ou teve sua permeabilidade alterada. Foi verificado que $94,1 \%$ da população de células não-marcadas não mostraram efeitos nem para anexina-V ou PI. 

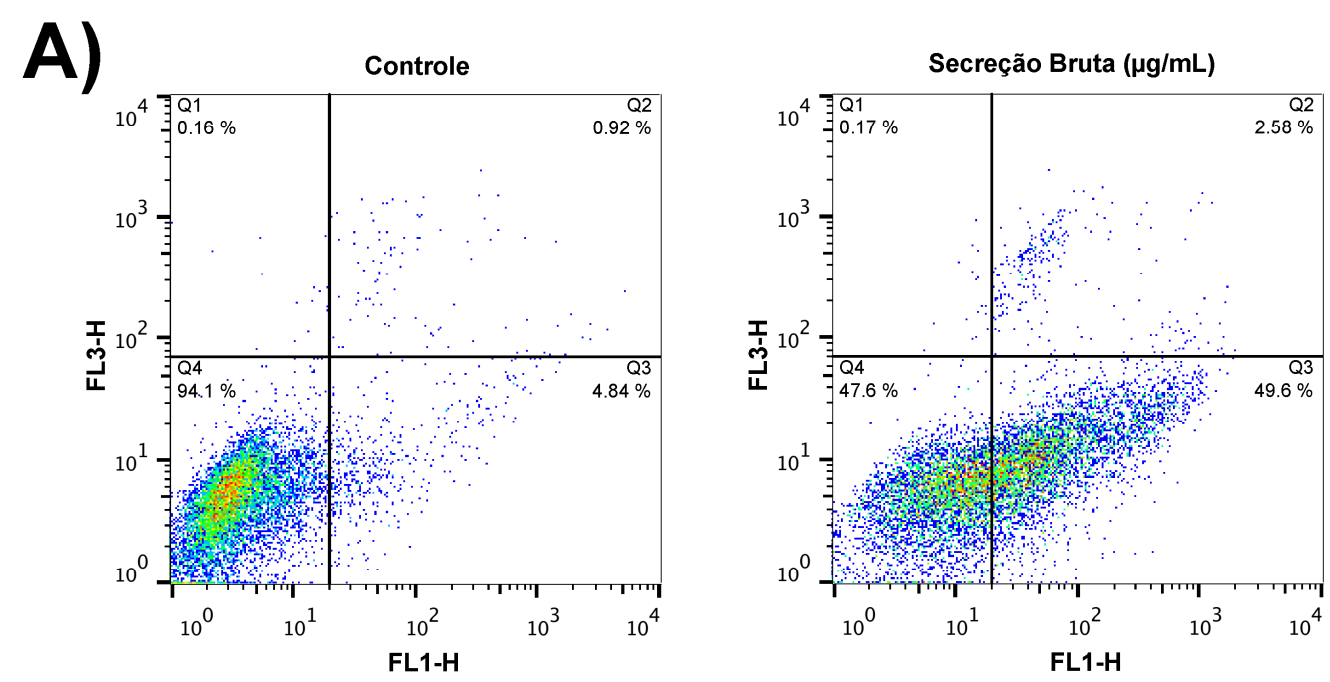

B)

lodeto de Propídeo

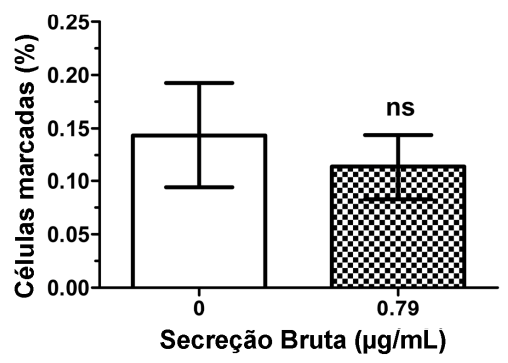

Duplamente Marcadas

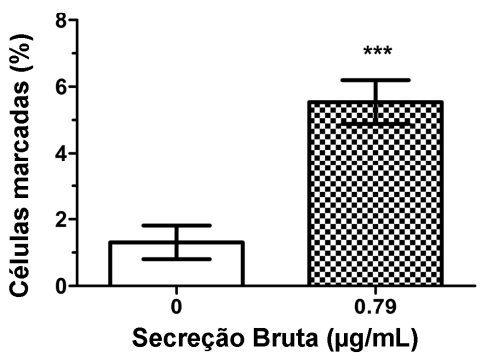

Não Marcadas

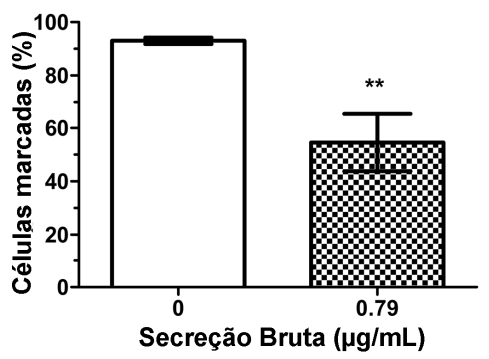

Anexina V-FITC

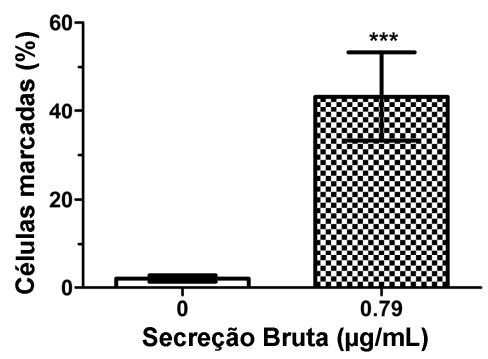

Figura 18. Efeitos da secreção cutânea bruta $P$. nattereri sobre a membrana plasmática observados com o emprego dos marcadores anexina-V (apoptose) e iodeto de propídeo (necrose). Os parâmetros foram avaliados por citometria de fluxo e os experimentos foram realizados em triplicata. (A) Gráficos bidimensionais utilizando os marcadores anexina- $\mathrm{V}^{+}$e iodeto de propídeo $\left(\mathrm{PI}^{+}\right)$, controle $(0 \mu \mathrm{g} / \mathrm{mL})$ e experimento $(0,79 \mu \mathrm{g} / \mathrm{mL})$ de células incubadas durante $24 \mathrm{~h}$ com secreção bruta de $P$. nattereri. Os gráficos mostram quatro quadrantes (Q1 a Q4) que representam células marcadas apenas com $\mathrm{PI}^{+}(\mathrm{Q} 1)$, células marcadas com anexina- $\mathrm{V}^{+}$e $\mathrm{Pl}^{+}(\mathrm{Q} 2)$, células marcadas apenas com anexina- $\mathrm{V}^{+}(\mathrm{Q} 3)$ e células não-marcados (Q4). Legenda: anexina- $\mathrm{V}^{+}$indica exposição de fosfatidilserina; $\mathrm{Pl}^{+}$indica permeabilidade da membrana plasmática. (B) Os gráficos de barras mostram a percentagem de células em cada quadrante. Legenda: ns = não significativo, ${ }^{* *}=p<0,01,{ }^{* * *}=p<0,001$. 


\subsection{Efeitos da secreção cutânea bruta de $P$. nattereri sobre no potencial de membrana mitocondrial das células de melanoma murino (B16F10)}

A determinação do potencial de membrana mitocondrial foi realizada através das análises das características funcionais das mitocôndrias. Foi verificado que a secreção cutânea bruta de $P$. nattereri induziu alterações significativas, afetando o potencial de membrana mitocondrial que, por sua vez, foi reduzido.

As células tratadas com a secreção bruta tiveram seu potencial de membrana mitocondrial afetado em 4,53\% ( $p<0,01$ ), como evidenciado na figura 19. Constata-se-se que houve uma redução na população de células que apresentaram rodamina 123 sequestrada pelas mitocôndrias. Considerando que rodamina 123 é uma molécula fluorescente catiônica permeável à membrana plasmática e que é rapidamente seqüestrada por mitocôndrias com potencial de membrana normalizado. Quando acontecem alterações, como no nosso experimento, o potencial de membrana da mitocôndria desencadeia um efluxo (saída) de rodamina 123 da mitocôndria.
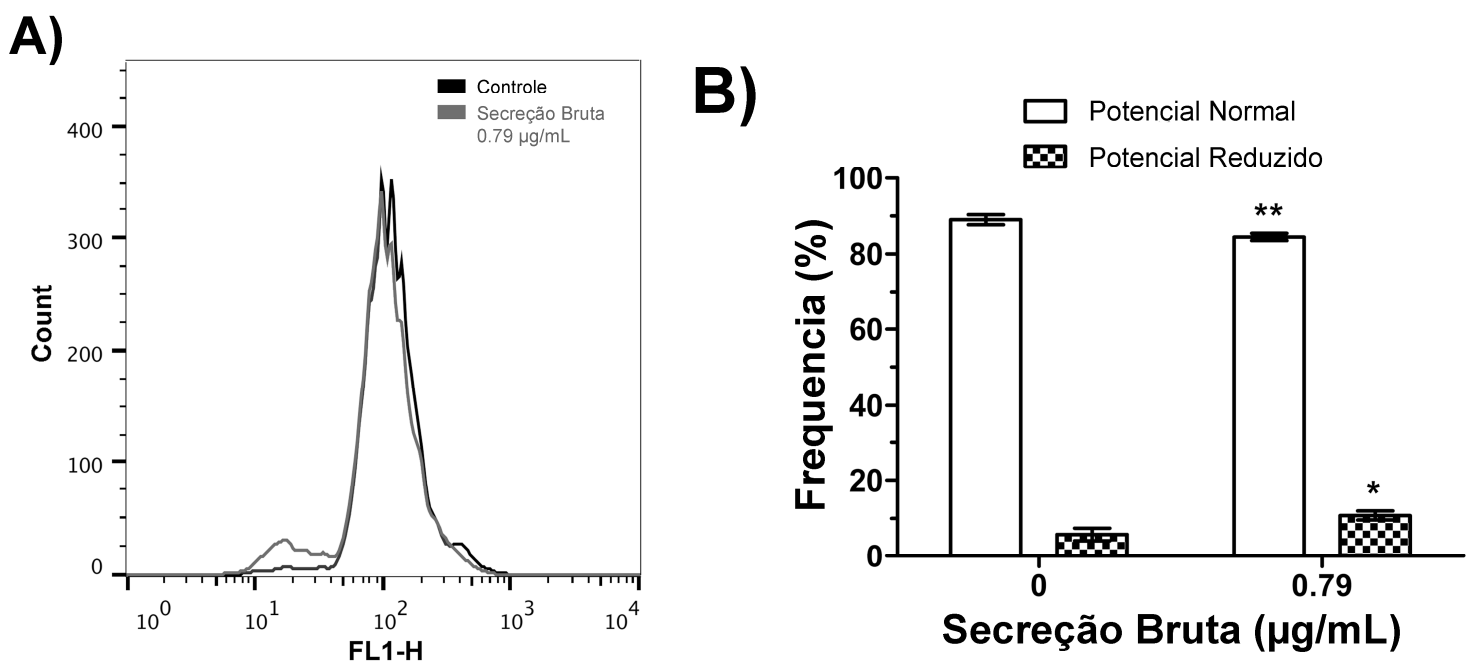

Figura 19. Efeitos da secreção cutânea bruta $P$. nattereri sobre o potencial de membrana mitocondrial avaliados por citometria de fluxo em células B16F10 tratadas por 24 h. (A) Contagem de fluorescência da rodamina 123 em células de melanoma tratadas e não-tratadas com a secreção bruta de $P$. nattereri. (B) Freqüência de células com potencial de membrana mitocondrial normal e reduzido. ${ }^{*}=P<0,05,{ }^{* *}=p<0,01$. Os experimentos foram realizados em triplicata. 


\subsection{Efeitos da secreção cutânea bruta de $P$. nattereri sobre o ciclo celular das células de melanoma murino (B16F10)}

A fim de investigar os efeitos induzidos pela secreção cutânea bruta de $P$. nattereri sobre o ciclo celular, as células de melanoma foram novamente tratadas com $0,79 \mu \mathrm{g} / \mathrm{mL}$ de secreção bruta durante $24 \mathrm{~h}$ e as análises de citometria de fluxo foram realizadas utilizando-se o marcador iodeto de propídeo. Os resultados apresentados na figura 20 mostraram algumas diferenças nas fases do ciclo celular de células não-tratadas e tratadas. Essa diferença foi muito discreta na fase G0/G1 $(51,07 \%$ versus $52,78 \%)$. No entanto, verificou-se um incremento de $3,24 \%$ $(25,64 \%)$ versus $28,88 \%)$ na proporção de células na fase $S$ (síntese) e uma diminuição de 4,94\% (23,29\% versus $18,35 \%)$ na proporção de células na fase G2/M, mostrando que houve uma tendência à parada do ciclo celular em células tratadas com a secreção bruta de $P$. nattereri. Infelizmente, a realização das análises estatísticas desses experimentos não foram possíveis devido ao número insuficiente de eventos em uma das repetições do tratamento.

\section{Ciclo Celular}

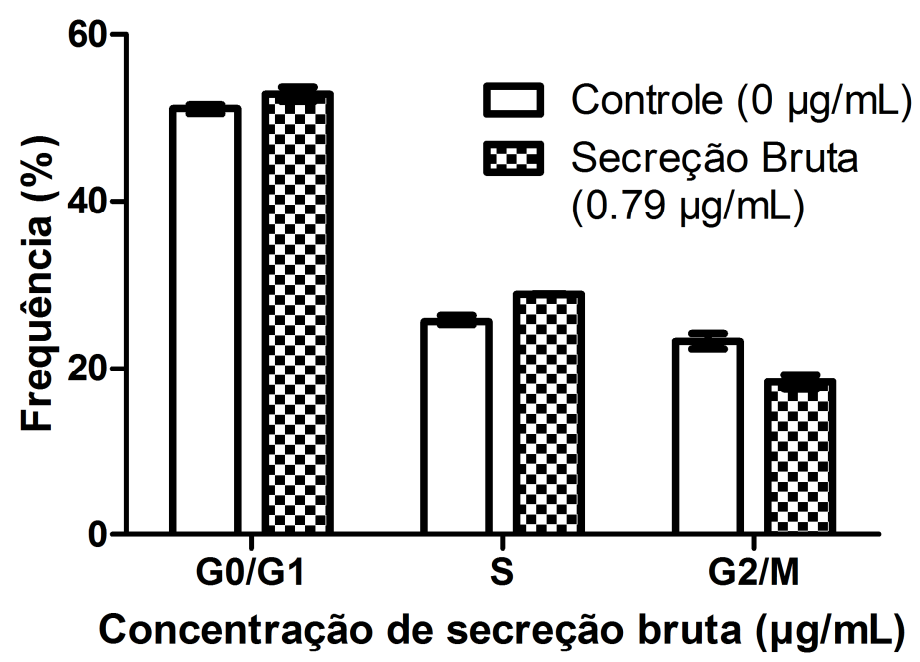

Figura 20. Efeitos da secreção cutânea bruta de $P$. nattereri sobre as fases do ciclo celular de células de melanoma murino (B16F10) após $24 \mathrm{~h}$ de incubação. As fases do ciclo celular foram analisadas após marcação com iodeto de propídeo e os parâmetros foram avaliados por citometria de fluxo. Os dados são expressos como a percentagem de G1, S e G2/M e representam as médias \pm SD (desvio padrão) dos experimentos realizados em triplicata. $\mathrm{O}$ grupo controle corresponde às células não-tratadas e o tratamento refere-se às células incubadas com $0,79 \mu \mathrm{g} / \mathrm{mL}$ da secreção cutânea bruta de $P$. nattereri. 
Segunda etapa: Identificação e caracterização biológica de peptídeos antimicrobianos e anticâncer presentes na secreção cutânea do anuro Physalaemus nattereri

\subsection{Fracionamento cromatográfico da secreção cutânea de}

\section{P. nattereri}

Alíquotas de $5,0 \mathrm{mg}$ da secreção bruta de $P$. nattereri foram inicialmente fracionadas em coluna $C_{18}$ por RP-HPLC (Shim-pack CLC-ODS, $6.0 \times 150 \mathrm{~mm}$ ) com um fluxo de $1 \mathrm{~mL} / \mathrm{min}$, obtendo-se o perfil cromatográfico apresentado na figura 21.

Tal perfil apresentou uma boa reprodutividade ao longo das 90 corridas cromatográficas realizadas, totalizando uma média de 127-135 frações por corrida cromatográfica.

5.8. Avaliação preliminar das atividades antibacteriana, antifúngica, hemolítica e antiproliferativa

A partir das frações cromatográficas obtidas de uma única corrida cromatográfica realizou-se um ensaio preliminar para avaliação da atividade antimicrobiana empregando-se a bactéria Gram-positiva Staphylococcus aureus e a bactéria Gram-negativa Enterobacter cloacae, com o intuito de se identificar as frações cromatográficas com atividade inibitória sobre a proliferação das bactérias testadas

As frações $46,53,121,122$, e 125 foram ativas contra $S$. aureus apresentando um percentual de inibição em torno de $70 \%$. Já as frações 1 e 121 exibiram atividade inibitória sobre a bactéria E.cloacae, com uma inibição em torno de $85 \%$ (Figura 21). 
bioativos do anuro Physalaemus nattereri (Steindachner, 1863)

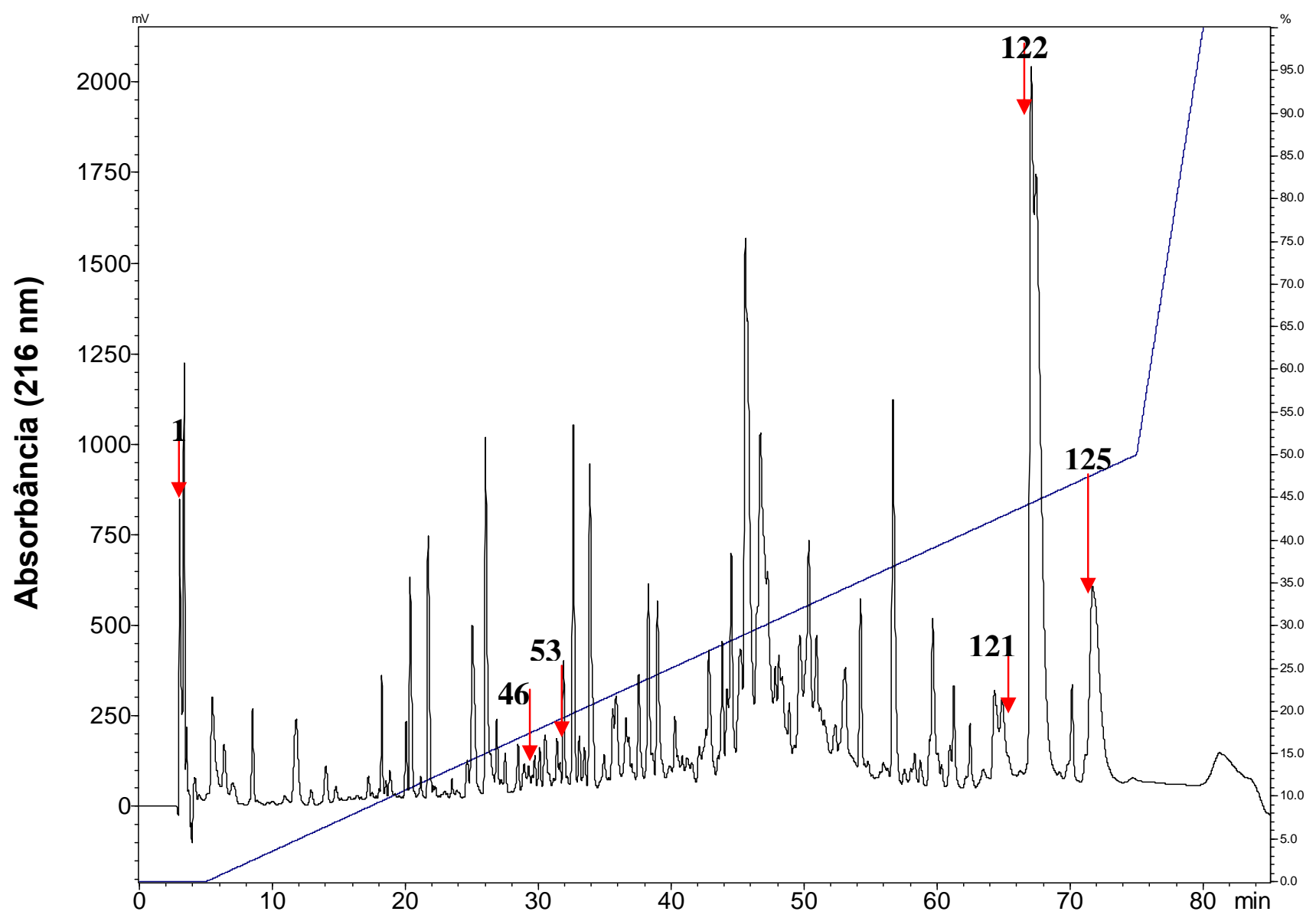

Figura 21. Perfil cromatográfico típico do fracionamento da secreção cutânea de Physalaemus nattereri em coluna $\mathrm{C}_{18}$ (Shim-pack CLC-ODS, $6.0 \times 150 \mathrm{~mm}$ ) em sistema HPLC da Shimadzu com emprego de gradiente linear de TFA 0,1\% (v/v) em acetonitrila. A detecção foi monitorada a $216 \mathrm{~nm}$ e a eluição realizada com fluxo de $1 \mathrm{~mL} / \mathrm{min}$. As frações contendo os peptídeos utilizados ao longo do presente trabalho estão indicadas com números que correspondem à sua ordem de eluição e possuem os seguintes tempos de retenção: Fração 1: 3.05; Fração 46: 30.30; Fração 53: 33.15; Fração 121: 67.12; Fração 122: 67.30; Fração 125: 72.99 minutos. 
Avaliação dos efeitos citotóxicos e antiproliferativos da secreção cutânea e de peptídeos bioativos do anuro Physalaemus nattereri (Steindachner, 1863)

As porcentagens de inibição obtidas estão apresentadas a seguir na Tabela 4.

Tabela. 4. Avaliação da atividade inibitória sobre a proliferação das bactérias patogênicas S. aureus e E. cloacae das frações cromatográficas obtidas com o fracionamento da secreção cutânea de Physalaemus nattereri por RP-HPLC em coluna $\mathrm{C}_{18}$.

\begin{tabular}{ccc}
\hline $\begin{array}{c}\text { Fração } \\
\text { cromatográfica }\end{array}$ & Bactéria & $\begin{array}{c}\text { Taxa de inibição da } \\
\text { proliferacão } \\
\text { celular (\%) }\end{array}$ \\
1 & E. cloacae & 79,1 \\
46 & S. aureus & 37,4 \\
53 & S. aureus & 37,4 \\
121 & S. aureus & 92,9 \\
121 & E. cloacae & 90,7 \\
122 & S. aureus & 92,4 \\
125 & S. aureus & 92,6 \\
\hline
\end{tabular}

Também foi realizado um ensaio com a finalidade de constatar a presença de atividade hemolítica nas frações testadas. Nenhuma das frações cromatográficas foi capaz de promover hemólise nas concentrações utilizadas.

A partir das frações cromatográficas obtidas de outra corrida cromatográfica, foi feito um ensaio para avaliação da atividade inibitória sobre os fungos patogênicos Candida albicans e Cryptococcus neoformans.

Para a espécie $C$. neoformans, as frações 121, 122, e 125 (Tabela 5 e Figura 22) foram ativas após 24 horas de incubação, apresentando as frações 121 e 122 uma taxa de inibição de 100\% e a fração 125 em torno de 70\% de inibição.

Um fato que merece destaque é que as frações que se mostraram ativas sobre as leveduras foram exatamente às mesmas que apresentaram atividade inibitória sobre a proliferação de bactérias como mostrado acima. Isso é bastante relevante se considerarmos o excelente potencial antifúngico e antimicrobiano desses peptídeos. 
Avaliação dos efeitos citotóxicos e antiproliferativos da secreção cutânea e de peptídeos

bioativos do anuro Physalaemus nattereri (Steindachner, 1863)

Tabela. 5. Avaliação da atividade inibitória sobre a proliferação do fungo patogênico Cryptococcus neoformans das frações cromatográficas obtidas com o fracionamento da secreção cutânea de Physalaemus nattereri por RP-HPLC em coluna $\mathrm{C}_{18}$.

\begin{tabular}{cc}
\hline $\begin{array}{c}\text { Fração } \\
\text { cromatográfica }\end{array}$ & $\begin{array}{c}\text { Taxa de inibição da proliferação } \\
\text { celular (\%) }\end{array}$ \\
121 & 100 \\
122 & 100 \\
125 & 70,0 \\
\hline
\end{tabular}

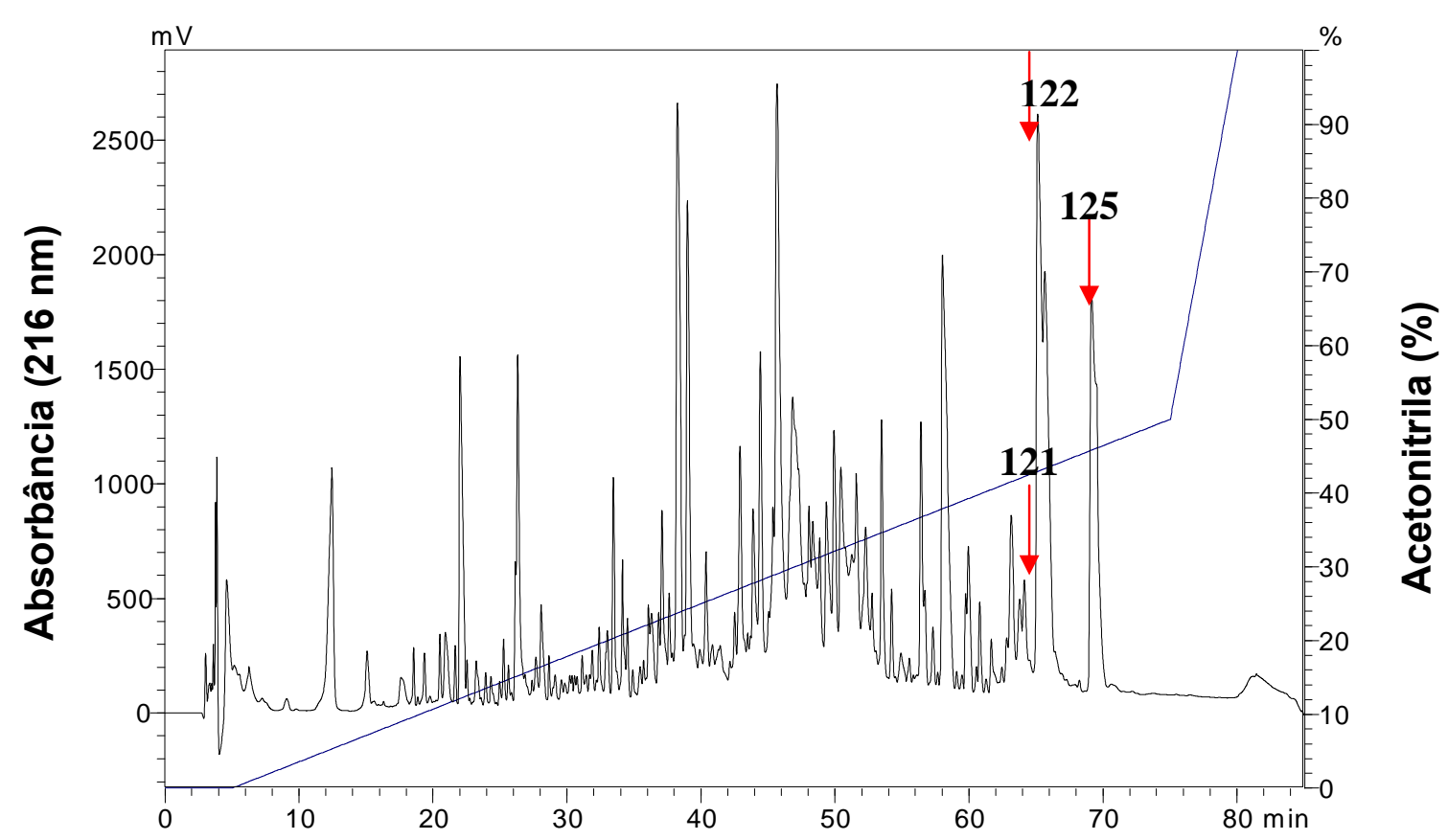

Figura 22. Perfil cromatográfico típico do fracionamento da secreção cutânea de Physalaemus nattereri. As frações que apresentaram atividade inibitória sobre a proliferação do fungo Cryptococcus neoformans estão assinaladas com setas vermelhas e possuem os seguintes tempos de retenção: Fração 121: 67.12; Fração 122: 67.30; Fração 125: 72.99 minutos.

Os resultados obtidos para a levedura $C$. albicans (Tabela 6 e Figura 23) mostrou que apenas as frações 97 e 122 foram ativas após 24 horas de incubação, apresentando uma taxa de inibição de $83,6 \%$ e $57,2 \%$ respectivamente (Tabela 6).

A fração 122 também foi ativa contra $C$. neoformans e para a cepa bacteriana S. aureus testadas anteriormente. 
Avaliação dos efeitos citotóxicos e antiproliferativos da secreção cutânea e de peptídeos

bioativos do anuro Physalaemus nattereri (Steindachner, 1863)

Tabela. 6. Avaliação da atividade inibitória sobre a proliferação do fungo patogênico Candida albicans das frações cromatográficas obtidas com o fracionamento da secreção cutânea de Physalaemus nattereri por RP-HPLC em coluna $\mathrm{C}_{18}$.

\begin{tabular}{cc}
$\begin{array}{c}\text { Fração } \\
\text { cromatográfica }\end{array}$ & $\begin{array}{c}\text { Taxa de inibição da proliferação } \\
\text { celular (\%) }\end{array}$ \\
97 & 83,6 \\
122 & 57,2 \\
\hline
\end{tabular}

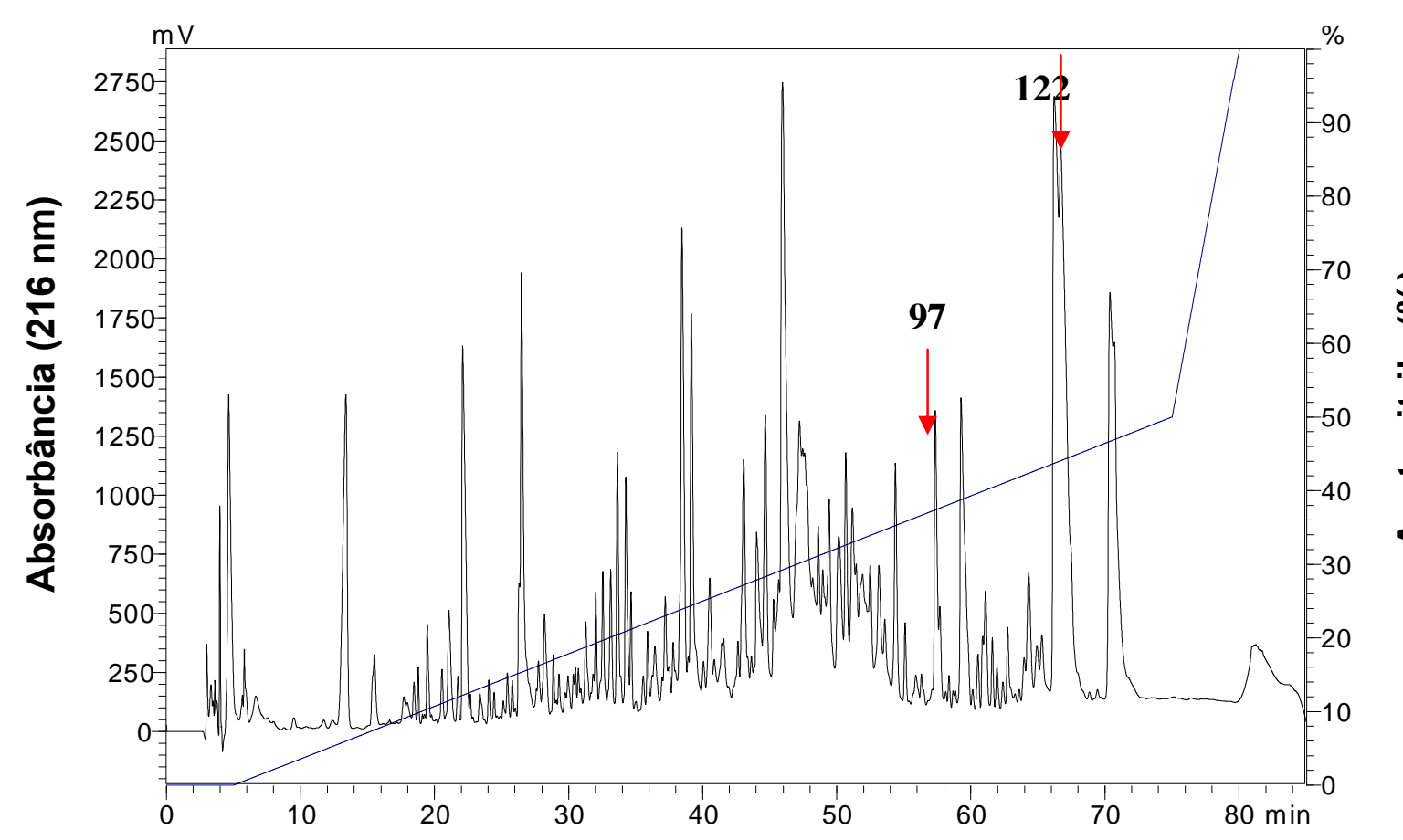

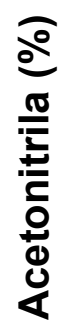

Figura 23. Perfil cromatográfico típico do fracionamento da secreção cutânea de Physalaemus nattereri. As frações que apresentaram atividade inibitória sobre a proliferação do fungo Candida albicans estão assinaladas com setas vermelhas e possuem os seguintes tempos de retenção: Fração 97: 57.40; Fração 122: 67.30 minutos.

Diante dos resultados apresentados é nítido que, pelo menos 3 frações cromatográficas se destacam por desempenharem atividade antimicrobiana contra bactérias Gram-positivas e Gram-negativas, (S. aureus e E. cloacae) e também atividade contra leveduras (C. albicans e $C$. neoformans). 
Os resultados obtidos nos ensaios hemolíticos mostraram o fraco poder de hemólise destes peptídeos frente às hemácias de doador saudável $\mathrm{O}^{+}$.

Com o intuito de avaliar a atividade antitumoral das frações cromatográficas provenientes do fracionamento da secreção de $P$. nattereri, foi realizada uma avaliação da atividade antiproliferativa das frações obtidas a partir de quatro corridas cromatográficas (ou seja, $20 \mathrm{mg}$ de veneno). Esse ensaio preliminar para avaliação da atividade antitumoral foi feito empregando-se a linhagem tumoral B16F10 (câncer de melanoma murino).

Os resultados obtidos revelaram a existência de 3 frações com atividade antiproliferativa sobre células de melanoma murino (Tabela 7 e Figura 24). Novamente observa-se que as mesmas frações que exibiram atividade antimicrobiana, também são capazes de comprometer a proliferação de células tumorais.

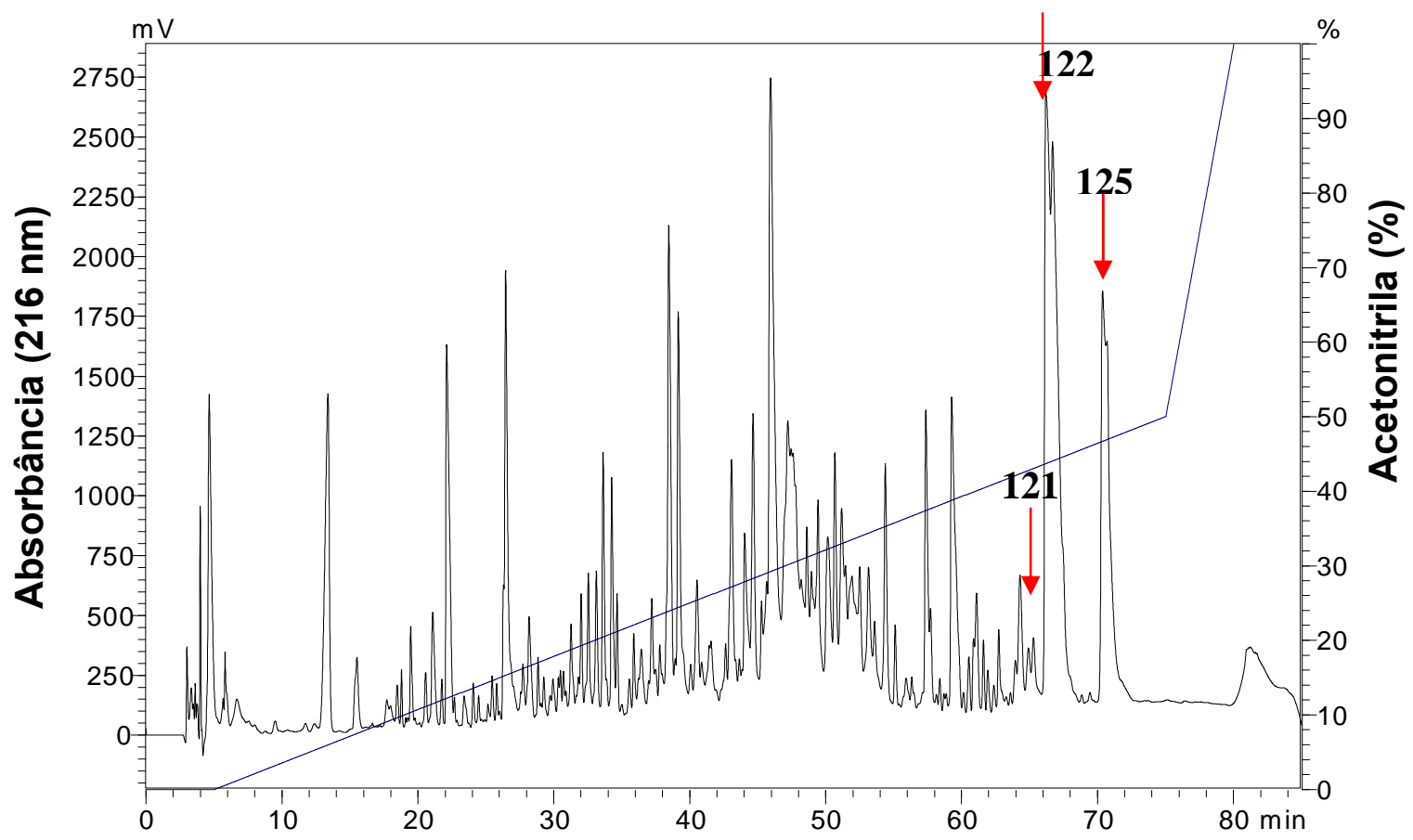

Figura 24. Perfil cromatográfico típico do fracionamento da secreção cutânea de Physalaemus nattereri. As frações que apresentaram atividade inibitória sobre a a proliferação de células de melanoma murino (B16F10) estão assinaladas com setas vermelhas e possuem os seguintes tempos de retenção: Fração 121: 67.12; Fração 122: 67.30; Fração 125: 72.99 minutos. 
Avaliação dos efeitos citotóxicos e antiproliferativos da secreção cutânea e de peptídeos

bioativos do anuro Physalaemus nattereri (Steindachner, 1863)

Tabela. 7. Avaliação da atividade inibitória sobre a proliferação de células de melanoma murino (B16F10) das frações cromatográficas obtidas com o fracionamento da secreção cutânea de Physalaemus nattereri por RP-HPLC em coluna $\mathrm{C}_{18}$.

\begin{tabular}{cc}
\hline Fração cromatográfica & $\begin{array}{c}\text { Taxa de inibição da proliferação } \\
\text { celular (\%) }\end{array}$ \\
121 & 18 \\
122 & 27 \\
125 & 17 \\
\hline
\end{tabular}

\subsection{Análise por espectrometria de massas tipo MALDI-TOF das frações cromatográficas de $P$. nattereri}

As frações cromatográficas obtidas foram secas, ressuspendidas e analisadas por espectrometria de massas do tipo MALDI-TOF-TOF (Autoflex II, Bruker Daltonics, Alemanha) varrendo uma faixa de $\mathrm{m} / z$ de 500 a $5000 \mathrm{Da}$. Os peptídeos cujas massas foram determinadas estão agrupados e representados na figura 25 , podendo-se destacar a abundância de componentes no intervalo de massas moleculares de 7 a 1,9 kDa presentes na secreção cutânea de $P$. nattereri. Também foi realizado o agrupamento dos componentes moleculares detectados em todas as frações cromatográficas obtidas com o fracionamento da secreção cutânea de $P$. nattereri por RP-HPLC em coluna $\mathrm{C}_{18}$. Pode-se observar claramente a predominância de peptídeos de baixa massa molecular (abaixo de 2.3 kDa). 


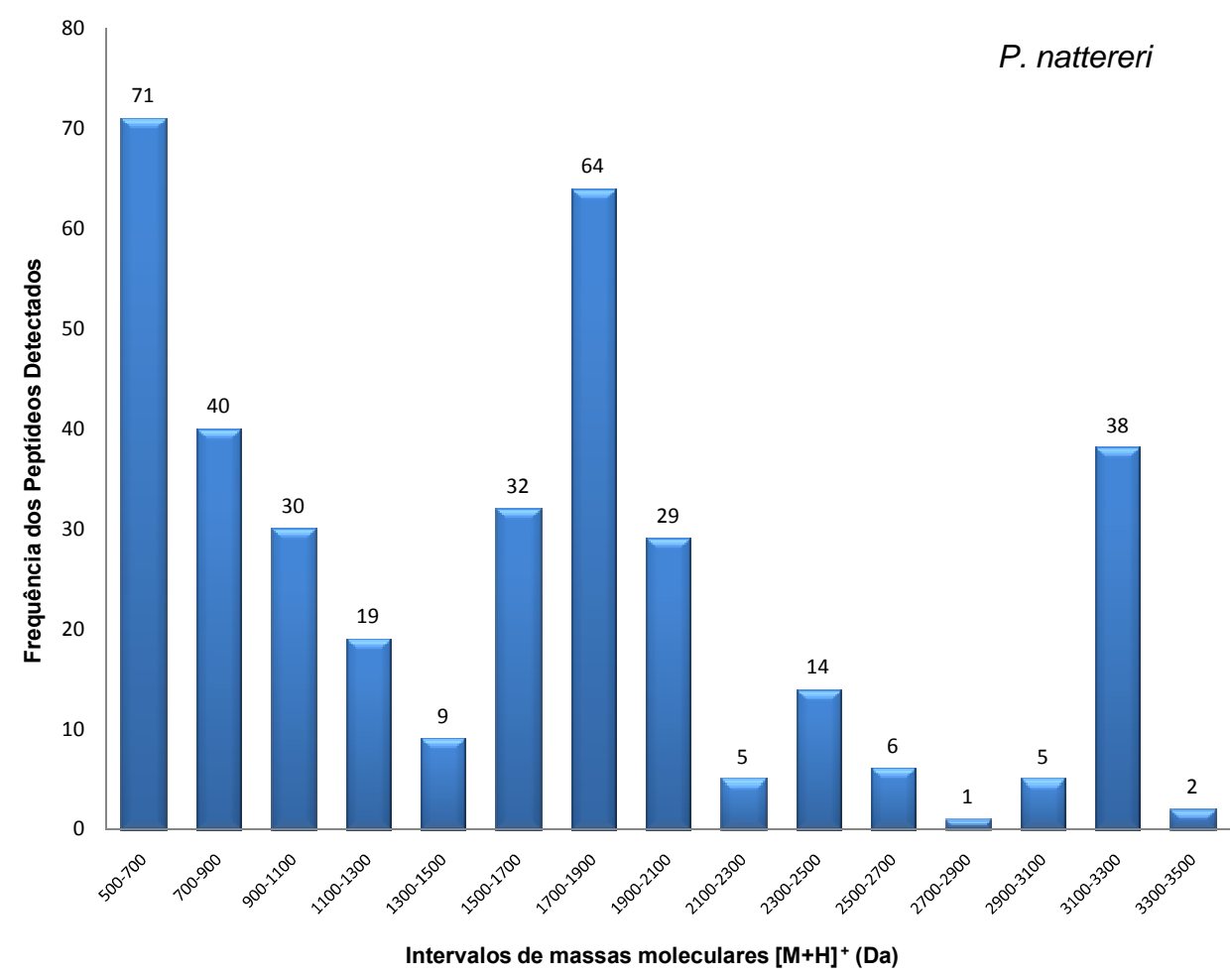

Figura 25. Frequência da composição peptídica da secreção cutânea de Physalaemus nattereri representadas em grupos de massas moleculares monoisotópicas obtidas pela análise por espectrometria de massas tipo MALDI-TOF nos modos refletido (matriz ácido $\alpha$-ciano 4-hidroxicinâmico) e linear (matriz ácido sinapínico). O ensaio foi realizado empregando-se as frações provenientes de uma única cromatografia.

A figura 26 apresenta a distribuição dos componentes moleculares presentes na secreção cutânea de $P$. nattereri detectados em função da suas massas moleculares na análise por MALDI-TOF/MS com relação aos seus tempos de retenção em sistema RP-HPLC. Todas as frações observadas apresentam massas moleculares abaixo de $3.5 \mathrm{kDa}$. 


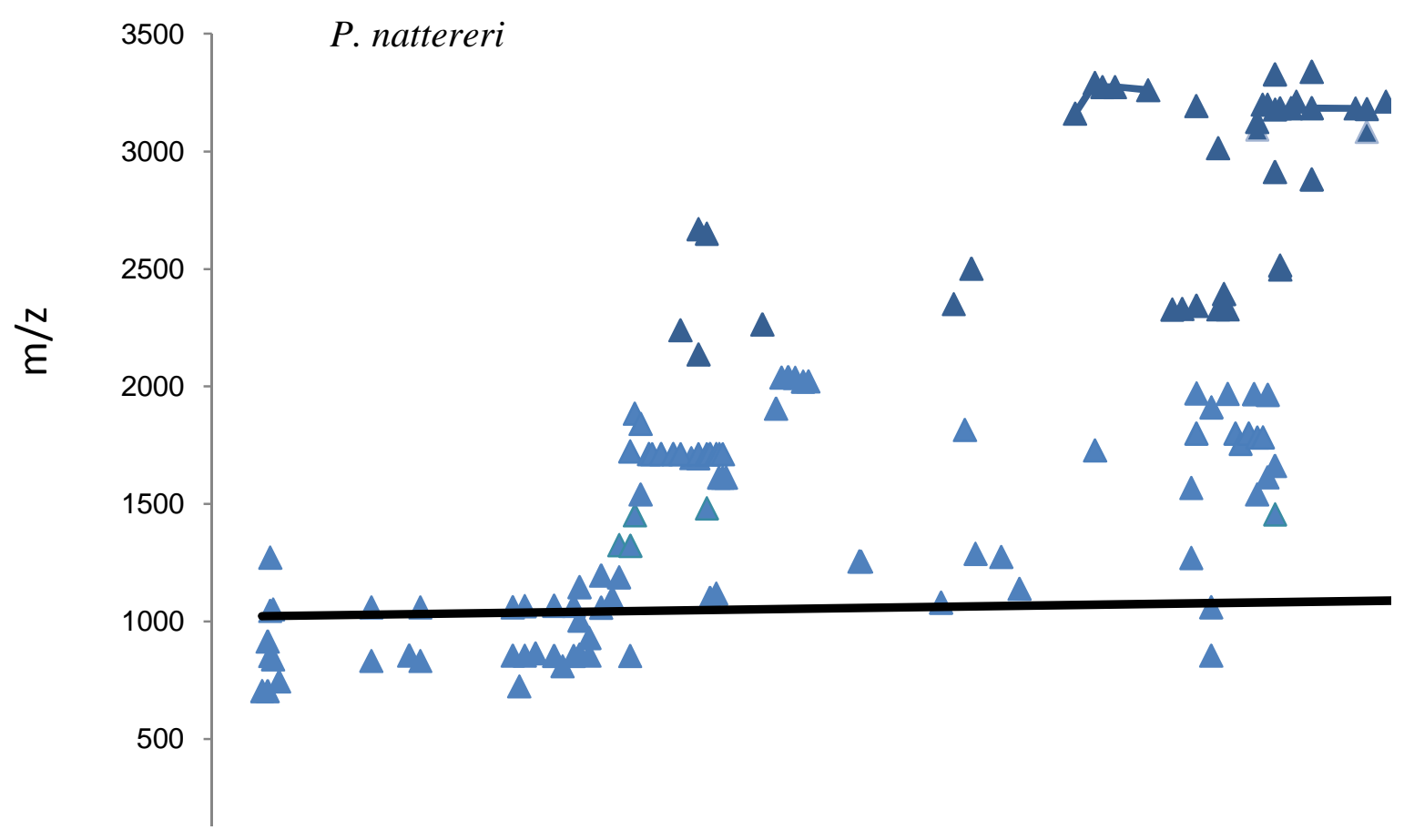

Figura 26. Distribuição dos componentes moleculares presentes na secreção cutânea de $P$. nattereri detectados em função da suas massas moleculares na análise por MALDI-TOF MS com relação aos seus tempos de retenção em sistema RP-HPLC.

\subsection{Purificação dos peptídeos antimicrobianos e anticâncer presentes na secreção cutânea de $P$. nattereri}

A escolha dos peptídeos a serem purificados no presente estudo foi feita em função das atividades inibitórias apresentadas pelas frações cromatográficas obtidas com o fracionamento da secreção cutânea bruta de $P$. nattereri sobre os microorganismos e células tumorais testadas. As frações contendo os peptídeos de massa monoisotópica 3.142 Da, 3.180 Da e 3.208 Da foram acumuladas e recromatografadas por RP-HPLC em coluna $C_{18}$ (Vydac 218TP54, 4,6 x $250 \mathrm{~mm}$ ) com eluição a $1.0 \mathrm{~mL} / \mathrm{min}$ de acordo com os gradientes apresentados na Figuras 27 , 28 e 29. 
Avaliação dos efeitos citotóxicos e antiproliferativos da secreção cutânea e de peptídeos

bioativos do anuro Physalaemus nattereri (Steindachner, 1863)

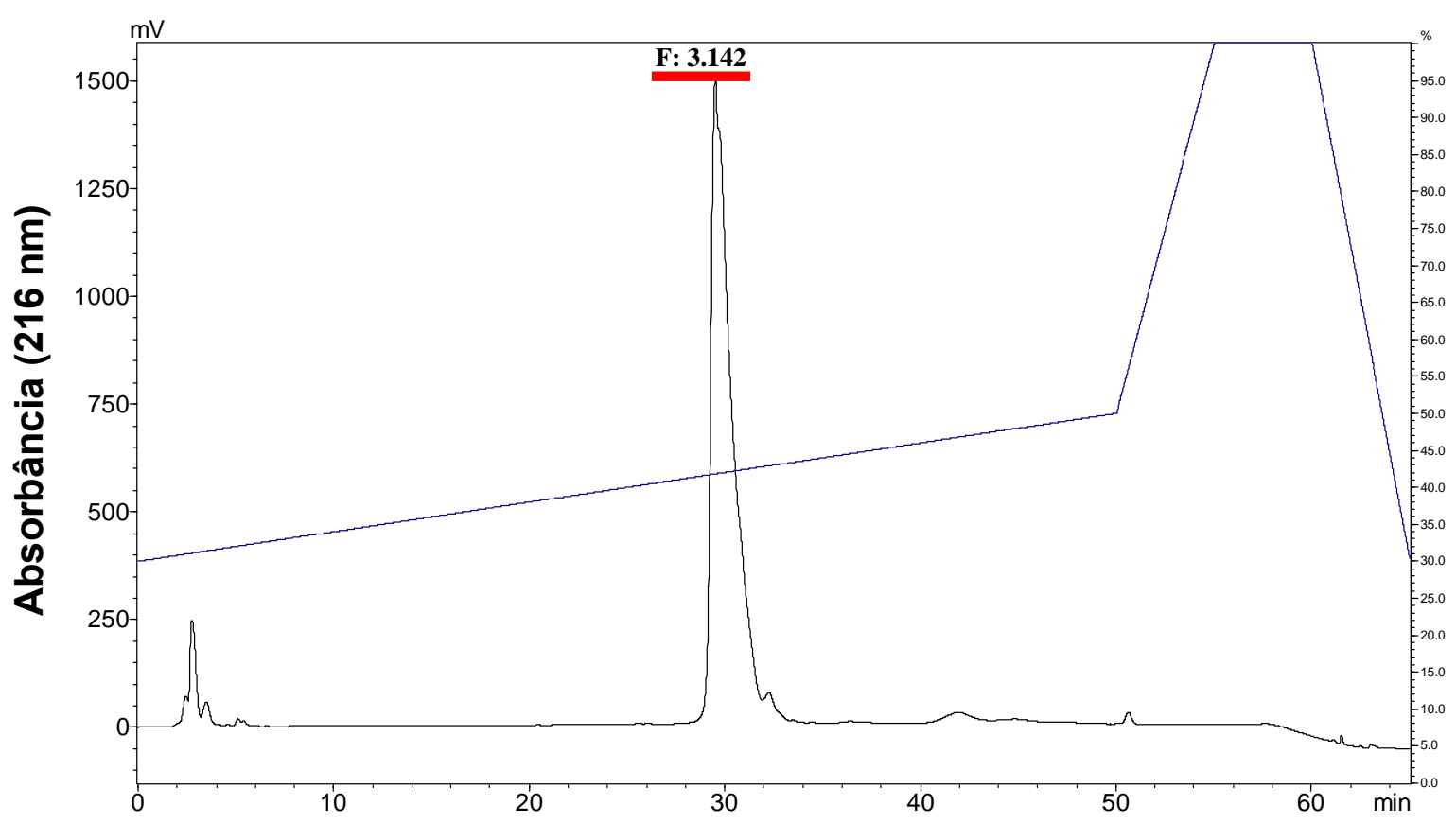

Figura 27. Recromatografia de peptídeo de interesse. A fração de massa $3.142 \mathrm{Da}$, foi purificada utilizando-se RP-HPLC em coluna $C_{18}$ (Vydac 218TP54, 4,6 x $250 \mathrm{~mm}$ ) com fluxo de $1 \mathrm{~mL} / \mathrm{min}$. A purificação do peptídeo 3.142 Da por realizada por meio da aplicação do gradiente de $25-50 \%$ de acetonitrila/TFA 0,1\% (v/v) por 30 minutos; A detecção foi realizada a $216 \mathrm{~nm}$. O pico que contem o peptídeo purificado está indicado por sua respectiva massa molecular monoisotópica $[\mathrm{M}+\mathrm{H}]^{+}$. 


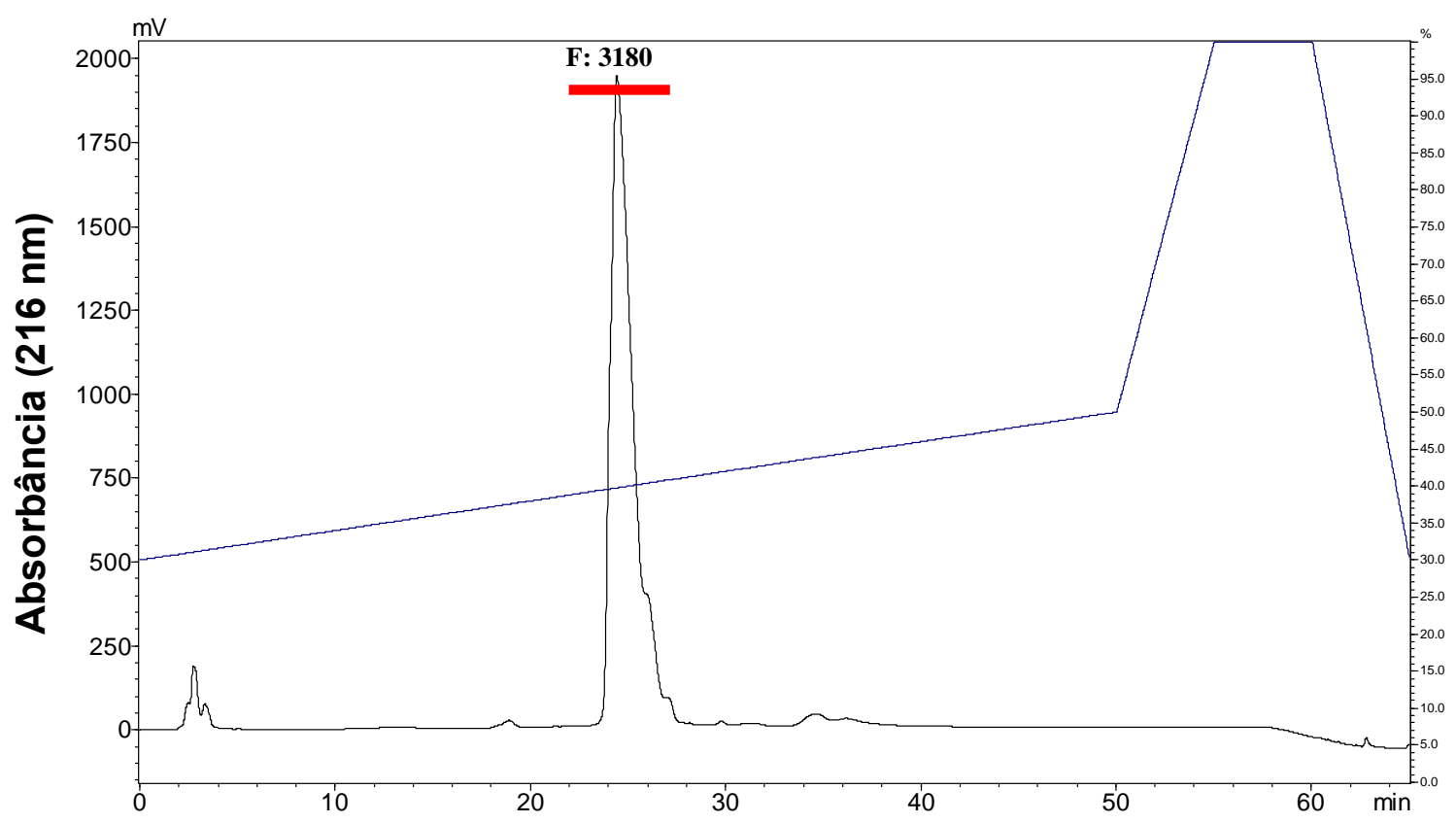

Figura 28. Recromatografia de peptídeo de interesse. A fração de massa $3.180 \mathrm{Da}$, foi purificada utilizando-se RP-HPLC em coluna $C_{18}$ (Vydac 218TP54, 4,6 x $250 \mathrm{~mm}$ ) com fluxo de $1 \mathrm{~mL} / \mathrm{min}$. A purificação do peptídeo 3.180 Da foi realizado por meio da aplicação do gradiente de $30-50 \%$ de acetonitrila/TFA 0,1\% (v/v) por 30 minutos; A detecção foi realizada a $216 \mathrm{~nm}$. O pico que contem o peptídeo purificado está indicado por sua respectiva massa molecular monoisotópica $[\mathrm{M}+\mathrm{H}]^{+}$.

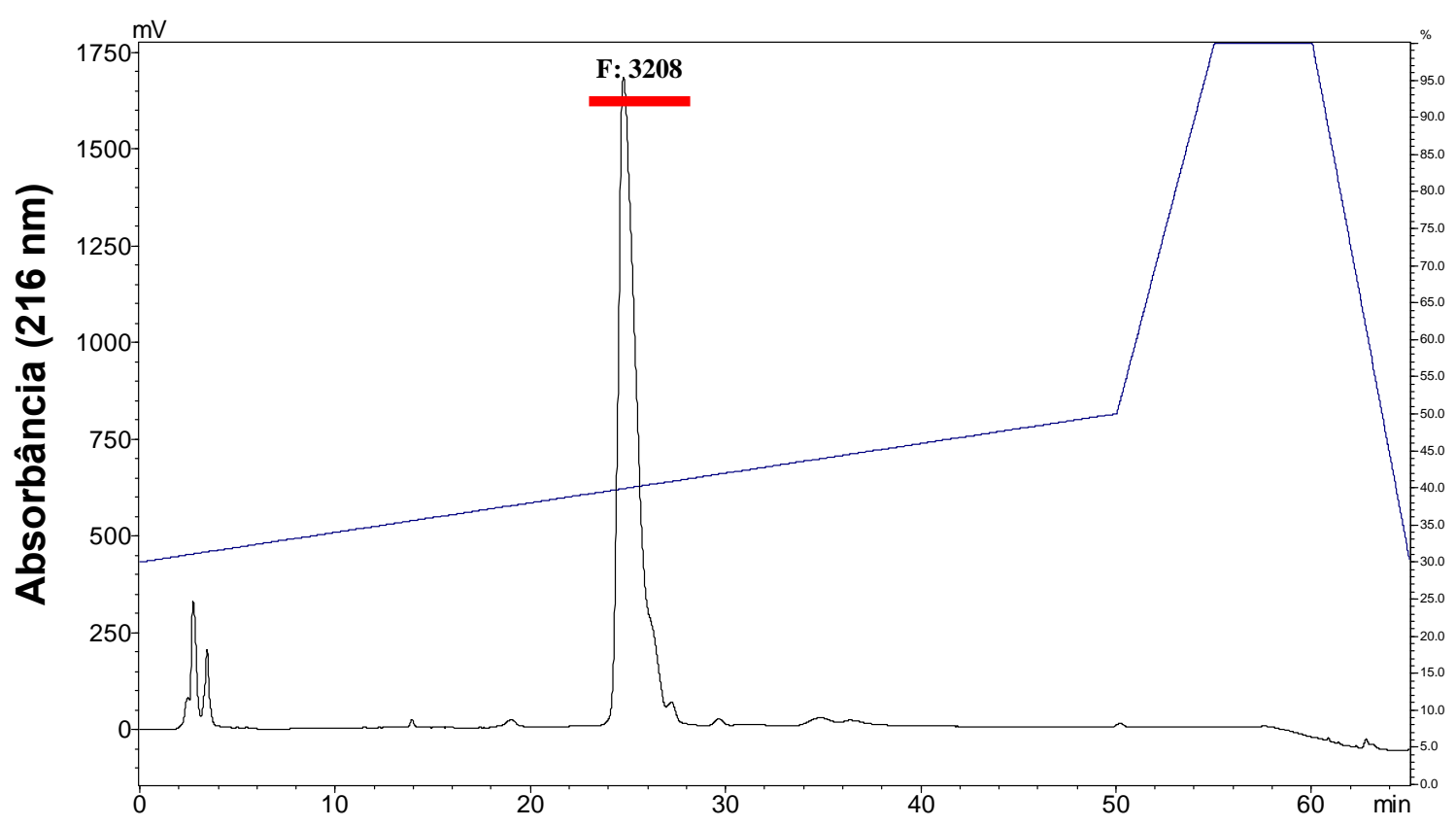

Figura 29. Recromatografia de peptídeo de interesse. As frações de massa 3.208 Da, foram purificadas utilizando-se RP-HPLC em coluna $\mathrm{C}_{18}$ (Vydac 218TP54, 4,6 x $250 \mathrm{~mm}$ ) com fluxo de $1 \mathrm{~mL} / \mathrm{min}$. A purificação do peptídeo $3.208 \mathrm{Da}$ foi realizada por meio da aplicação do gradiente de $30-50 \%$ de acetonitrila/TFA $0,1 \%(\mathrm{v} / \mathrm{v})$ por 30 minutos; A detecção foi realizada a $216 \mathrm{~nm}$. O pico que 198 ntem o peptídeo purificado está indicado por sua respectiva massa molecular monoisotópica $[\mathrm{M}+\mathrm{H}]^{+}$. 
Avaliação dos efeitos citotóxicos e antiproliferativos da secreção cutânea e de peptídeos bioativos do anuro Physalaemus nattereri (Steindachner, 1863)

Com finalidade de verificar o seu grau de homogeneidade, as frações de interesse resultantes das recromatografias foram analisadas por meio de espectrometria de massa do tipo MALDI-TOF, no modo refletor de íons positivos na faixa de massa de 400 a $8.000 \mathrm{Da}$. Os espectros resultantes das análises podem ser visualizados nas figuras 30,31 e 32 , exibidas a seguir.

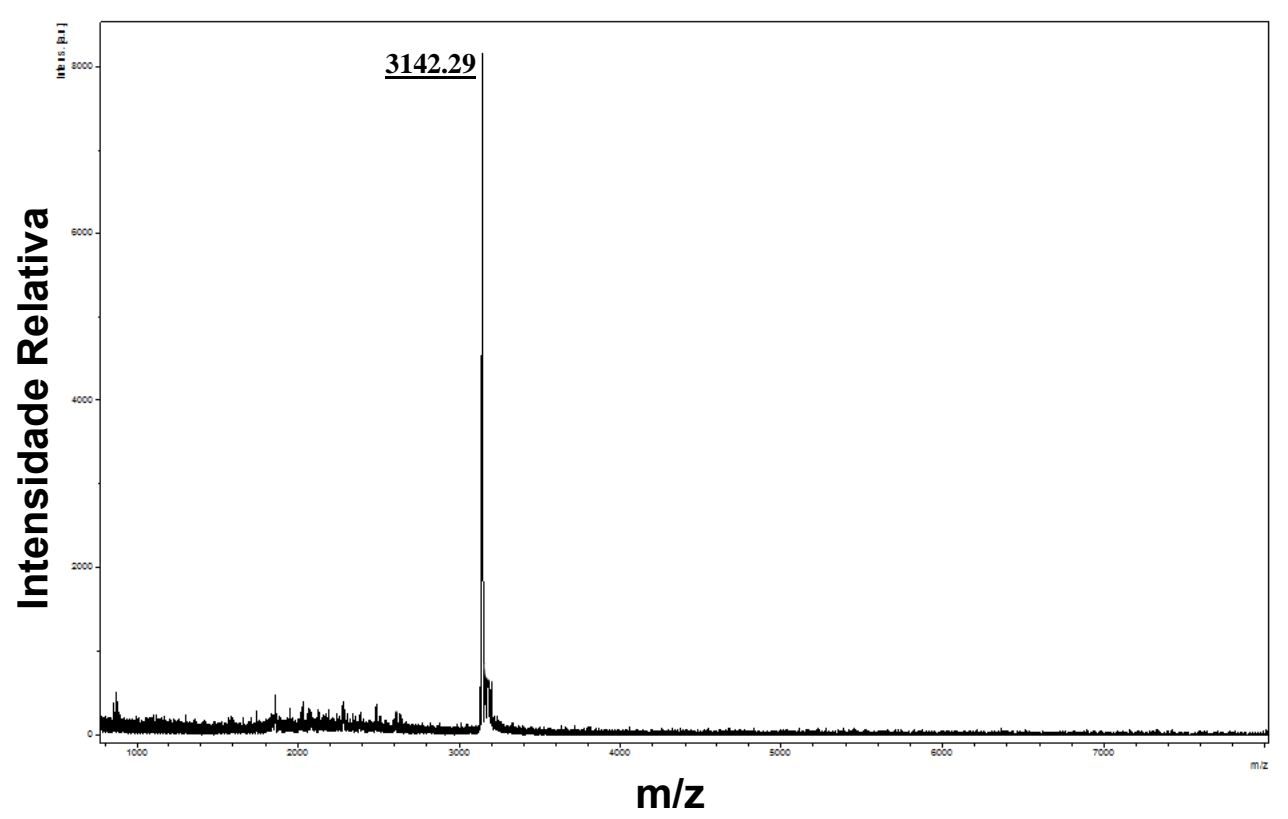

Figura 30. Espectro de massa do peptídeo de massa molecular $3.142 \mathrm{Da}$ após recromatografia (análise por espectrometria de massa do tipo MALDI-TOF, no modo refletor de íons positivos na faixa de massa de 400 a $8.000 \mathrm{Da}$ ). 
Avaliação dos efeitos citotóxicos e antiproliferativos da secreção cutânea e de peptídeos

bioativos do anuro Physalaemus nattereri (Steindachner, 1863)

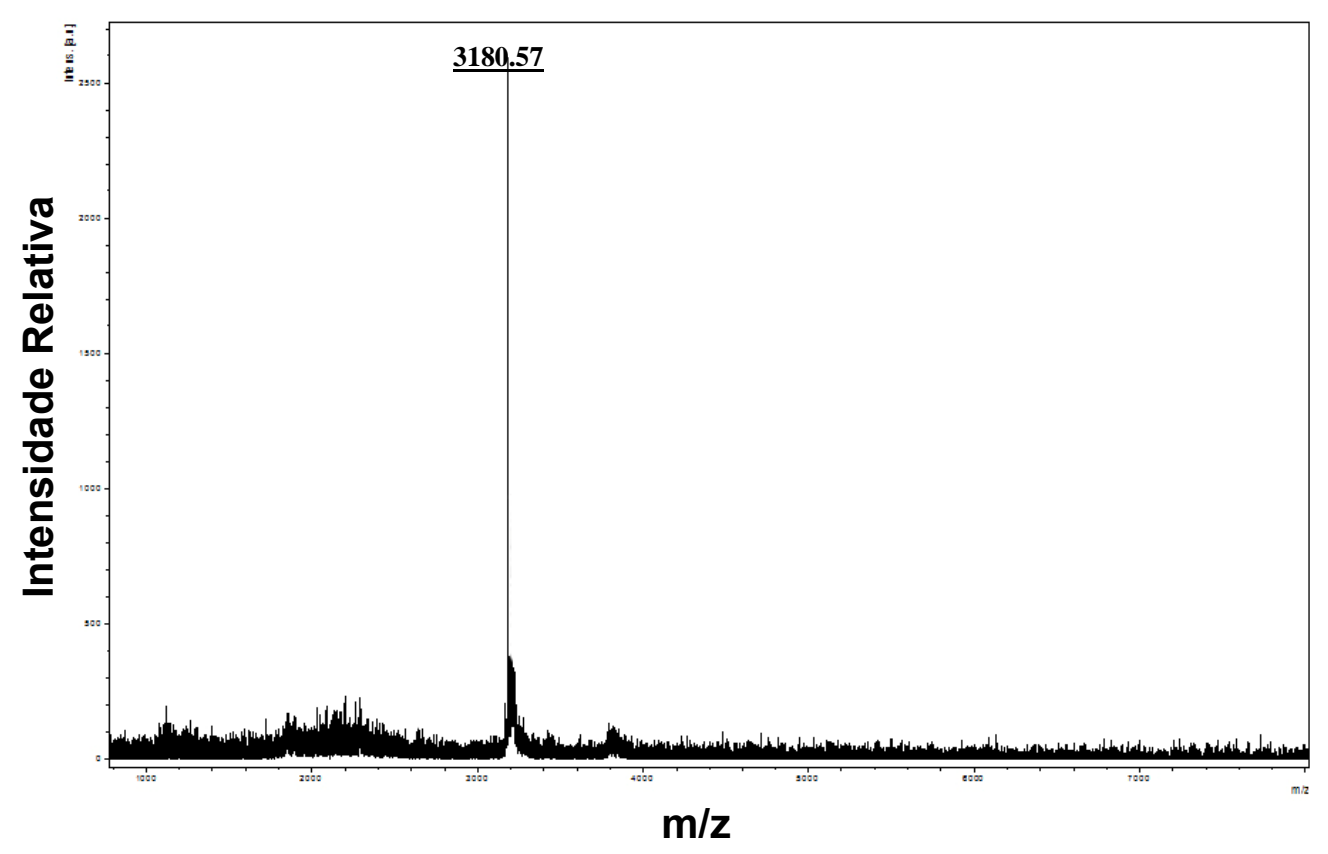

Figura 31. Espectro de massa do peptídeo de massa molecular $3.180 \mathrm{Da}$ após recromatografia (análise por espectrometria de massa do tipo MALDI-TOF, no modo refletor de íons positivos na faixa de massa de 400 a $8.000 \mathrm{Da}$ ).

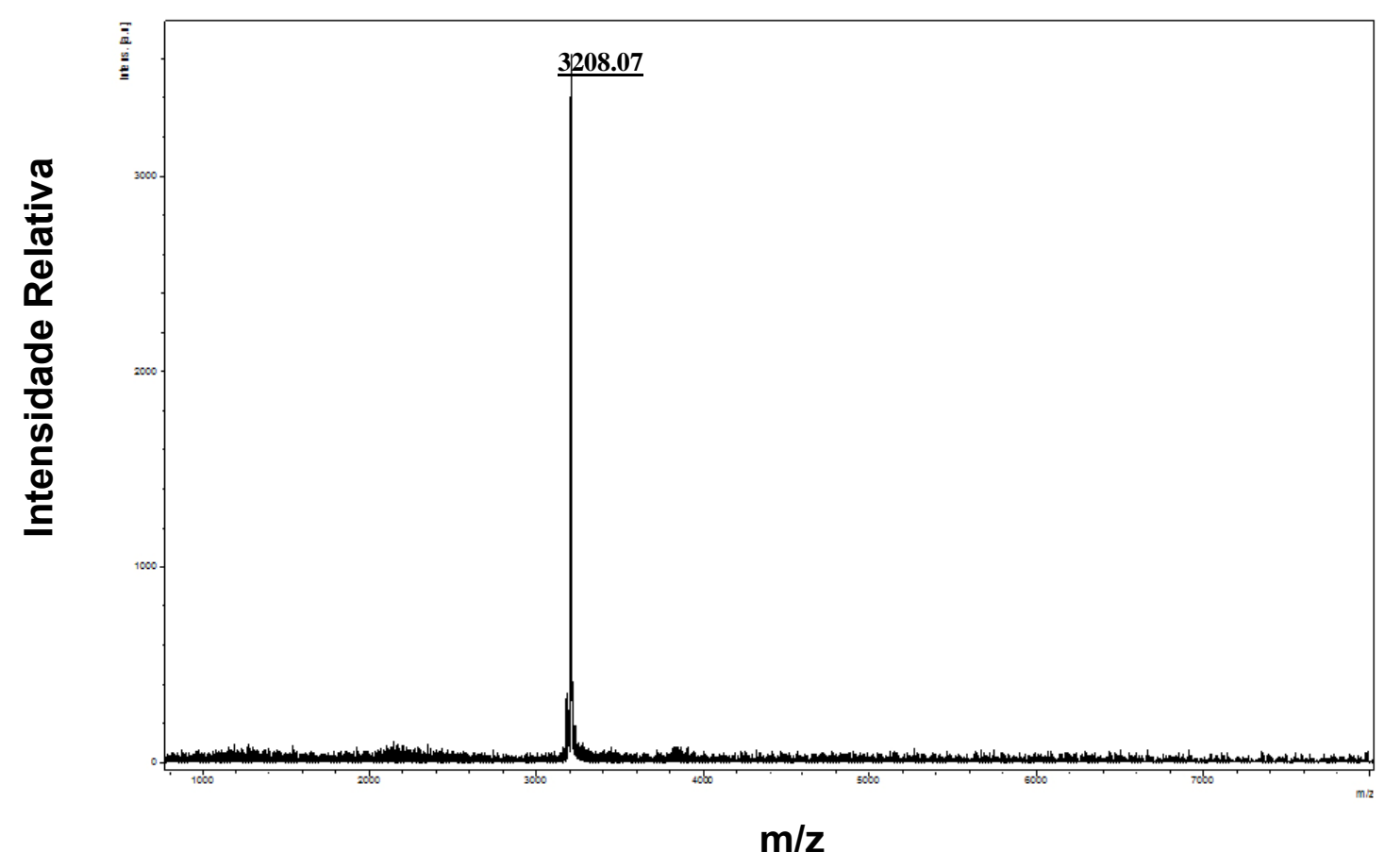

Figura 32. Espectro de massa do peptídeo de massa molecular 3.208 Da após recromatografia (análise por espectrometria de massa do tipo MALDI-TOF, no modo refletor de íons positivos na faixa de massa de 400 a $8.000 \mathrm{Da}$ ). 


\subsection{Identificação dos peptídeos antimicrobianos e anticâncer presentes na secreção cutânea de $\boldsymbol{P}$. nattereri}

As análise por espectrometria de massas permitiram concluir que os três peptídeos bioativos isolados no presente estudo correspondem aos peptídeos nattererinas, previamente identificados em estudos anteriores realizados por nosso grupo também empregando-se a secreção cutânea do anuro $P$. nattereri (Honorato, 2009).

Nesse estudo, tais peptídeos isolados foram submetidos a seqüenciamento químico (degradação de Edman) resultando em três peptídeos homólogos com 30 resíduos de aminoácidos (Figura 33):

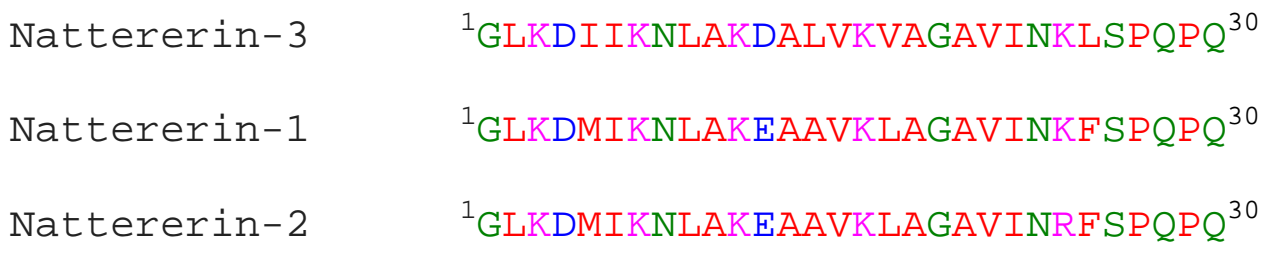

Nattererin-2
${ }^{1}$ GLKDMIKNLAKEAAVKLAGAVINRFSP QP $Q^{30}$

Figura 33. Estruturas primárias das nattererinas 1, 2 e 3 previamente isoladas e caracterizadas quimicamente.

No estudo desenvolvido por Honorato (2009) foi comprovada, por meio de esterificação de Fisher e análise por MALDI-TOF MS, que as nattererinas não apresentam a porção C-terminal amidada.

Em relação às nattererinas 1 e 2, a única diferença entre elas está no aminoácido que ocupa a posição 24. Na Nattererina-1 tem-se uma lisina (K) e na Nattererina-2 encontra-se uma arginina $(\mathrm{R})$ nessa posição. 


\subsection{Avaliação dos efeitos citotóxicos e antiproliferativos das nattererinas sobre células tumorais da linhagem HeLa}

\subsubsection{Efeitos sobre a viabilidade celular}

Os peptídeos purificados (nattererinas 1, 2, e 3) produzidos por síntese química foram dissolvidos na concentração inicial de $128 \mu \mathrm{M}$ e diluídos até uma concentração final de $0,125 \mu \mathrm{M}$ em meio de cultura DMEM completo (tamponado com bicarbonato de sódio, suplementado com $10 \%$ de soro fetal bovino e $1 \%$ de antibiótico) e incubados por 24 horas com a linhagem celular de câncer de colo uterino humano (HeLa) para avaliação de seus efeitos sobre a viabilidade celular.

Para fins de comparação dos efeitos citotóxicos sobre as células tumorais, as nattererinas foram também incubadas com células de fibroblastos normais (NIH-3T3) pelo mesmo período de tempo (Figuras 34, 35 e 36).

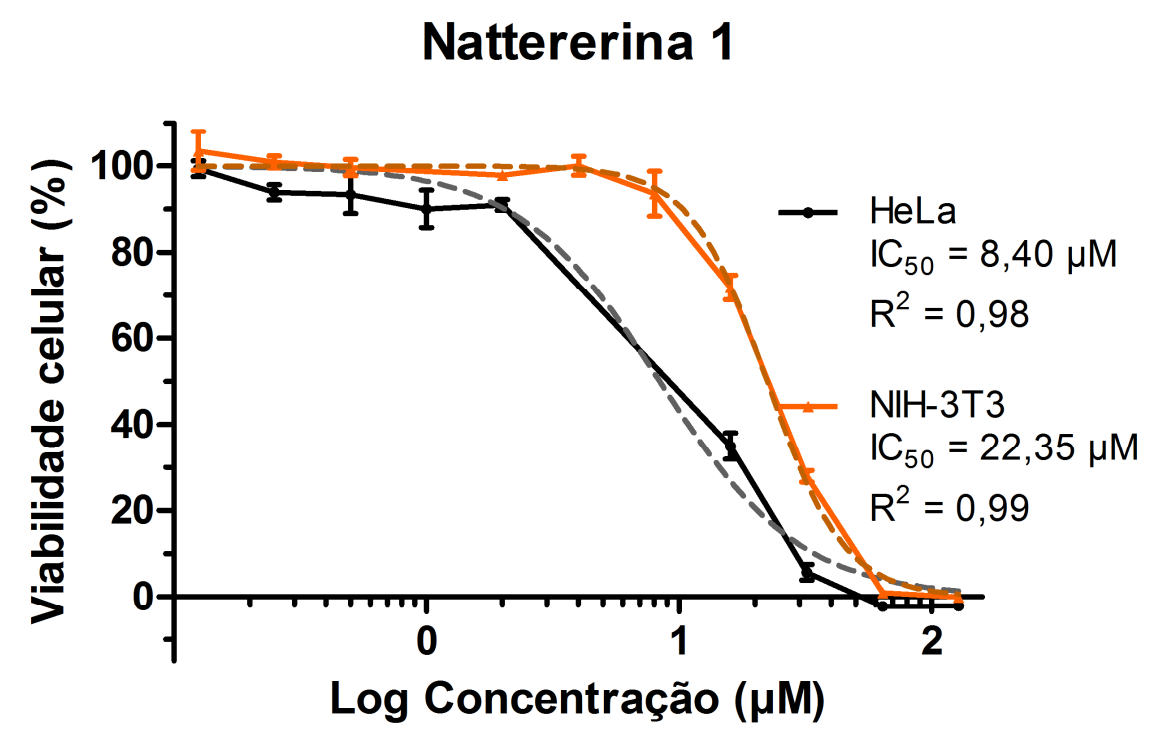

Figura 34. Porcentagem de viabilidade celular das linhagens celulares de câncer do colo uterino (HeLa) e fibroblastos murino normal (NIH-3T3) após a incubação por 24 horas com diferentes concentrações do peptídeo nattererina 1 (3180,57 Da). 


\section{Nattererina 2}

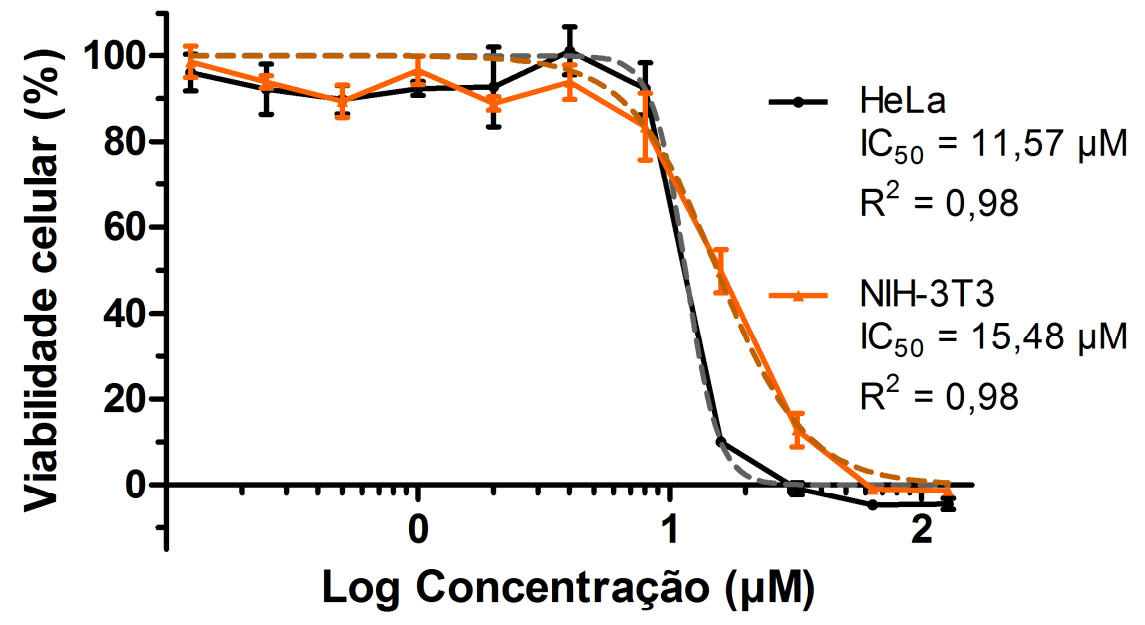

Figura 35. Porcentagem de viabilidade celular das linhagens celulares de câncer do colo uterino (HeLa) e fibroblastos murino normal (NIH-3T3) após a incubação por 24 horas com diferentes concentrações do peptídeo nattererina 2 (3208,07 Da).

\section{Nattererina 3}

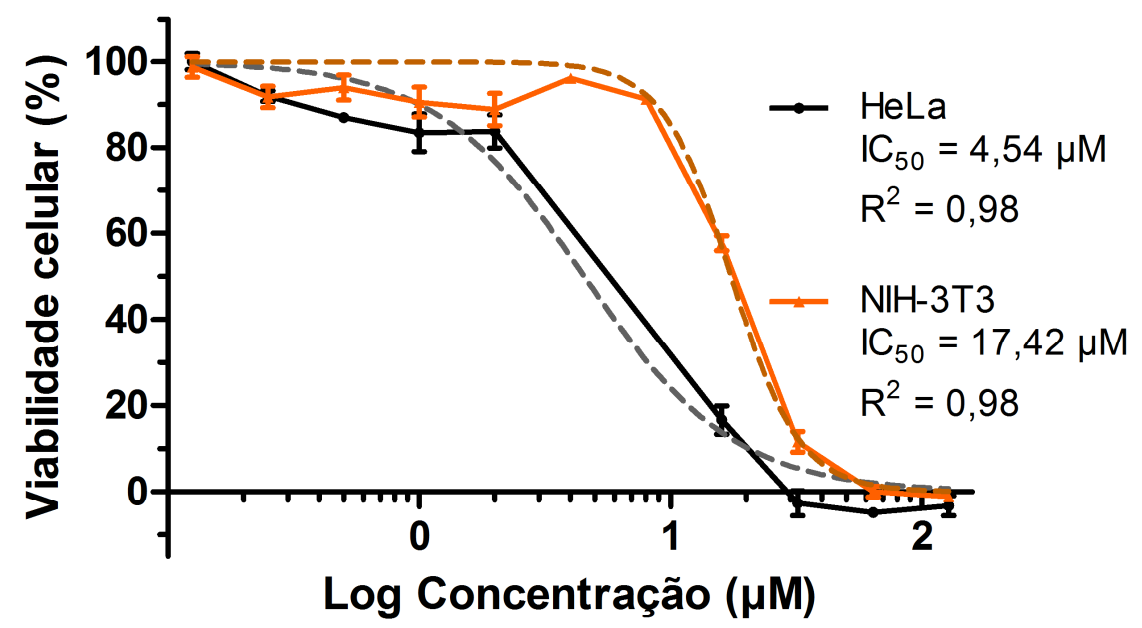

Figura 36. Porcentagem de viabilidade celular das linhagens celulares de câncer do colo uterino (HeLa) e fibroblastos murino normal (NIH-3T3) após a incubação por 24 horas com diferentes concentrações do peptídeo nattererina 3 (3142,29 Da). 
De acordo com os resultados apresentados as nattererinas 1,2 e 3 apresentaram atividade citotóxica sobre a linhagem tumoral HeLa na mesma proporção variando a concentração capaz de inviabilizar $50 \%$ das células $\left(\mathrm{IC}_{50}\right)$ de 4,54 a $11,57 \mu \mathrm{M}$ (Tabela 8).

No entanto, observou-se uma diferença sobre a atividade desses peptídeos sobre os fibroblastos normais ( $\mathrm{NIH}-3 \mathrm{~T} 3$ ) com um $\mathrm{IC}_{50}$ variando de 15,48 a 22,35 $\mu \mathrm{M}$. As diferenças encontradas nos valores de $\mathrm{IC}_{50}$ para as diferentes linhagens celulares testadas podem sugerir que a atividade das nattererinas é dependente da composição da membrana plasmática da célula testada.

Tabela. 8. Comparação da atividade citotóxica sobre as linhagens celulares HeLa (câncer de colo uterino) e NIH-3T3 (fibroblasto normal) das nattererinas 1, 2 e 3.

\begin{tabular}{ccc}
\hline Peptídeo & IC $_{50}$ (HeLa) & IC $_{50}$ (NIH-3T3) \\
Nattererina 1 (3180 Da) & $8,40 \mu \mathrm{M}$ & $22,35 \mu \mathrm{M}$ \\
Nattererina 2 (3208 Da) & $11,57 \mu \mathrm{M}$ & $15,48 \mu \mathrm{M}$ \\
Nattererina 3 (3142 Da) & $4,54 \mu \mathrm{M}$ & $17,42 \mu \mathrm{M}$ \\
\hline
\end{tabular}

\subsubsection{Efeitos sobre a morfologia celular}

As células de câncer de colo uterino (HeLa) e as células de fibroblastos normais (NHI-3T3) foram inspecionadas quanto à alterações na morfologia celular empregando-se microscopia de contraste de fase após incubação na presença das nattererinas (produzidas por síntese química).

As linhagens celulares em estudo foram incubadas com os peptídeos-teste desde a concentração máxima de $128 \mu \mathrm{M}$ até a concentração de $0,125 \mu \mathrm{M}$. Após o tratamento com as nattererinas, foi possível perceber claramente 0 efeito dose-dependente promovido pelo tratamento. 
Avaliação dos efeitos citotóxicos e antiproliferativos da secreção cutânea e de peptídeos

bioativos do anuro Physalaemus nattereri (Steindachner, 1863)

As células dos controles empregados nos experimentos realizados (ou seja, incubação por 24 horas na ausência dos peptídeos-teste) apresentaram morfologia bem definida, membrana citoplasmática íntegra, núcleo e nucléolos definidos (Figura 37).

No caso das células incubadas por 24 horas com os peptídeos-teste na concentração máxima de $128 \mu \mathrm{M}$, foram observadas alterações como a perda do formato celular, a ausência de núcleo e nucléolos definidos e a e presença de debris celulares e que na concentração mais baixa empregada $(0,125 \mu \mathrm{M})$, a morfologia celular mostrou-se semelhante aos controles empregados, sem alterações morfológicas relevantes (Figura 37).
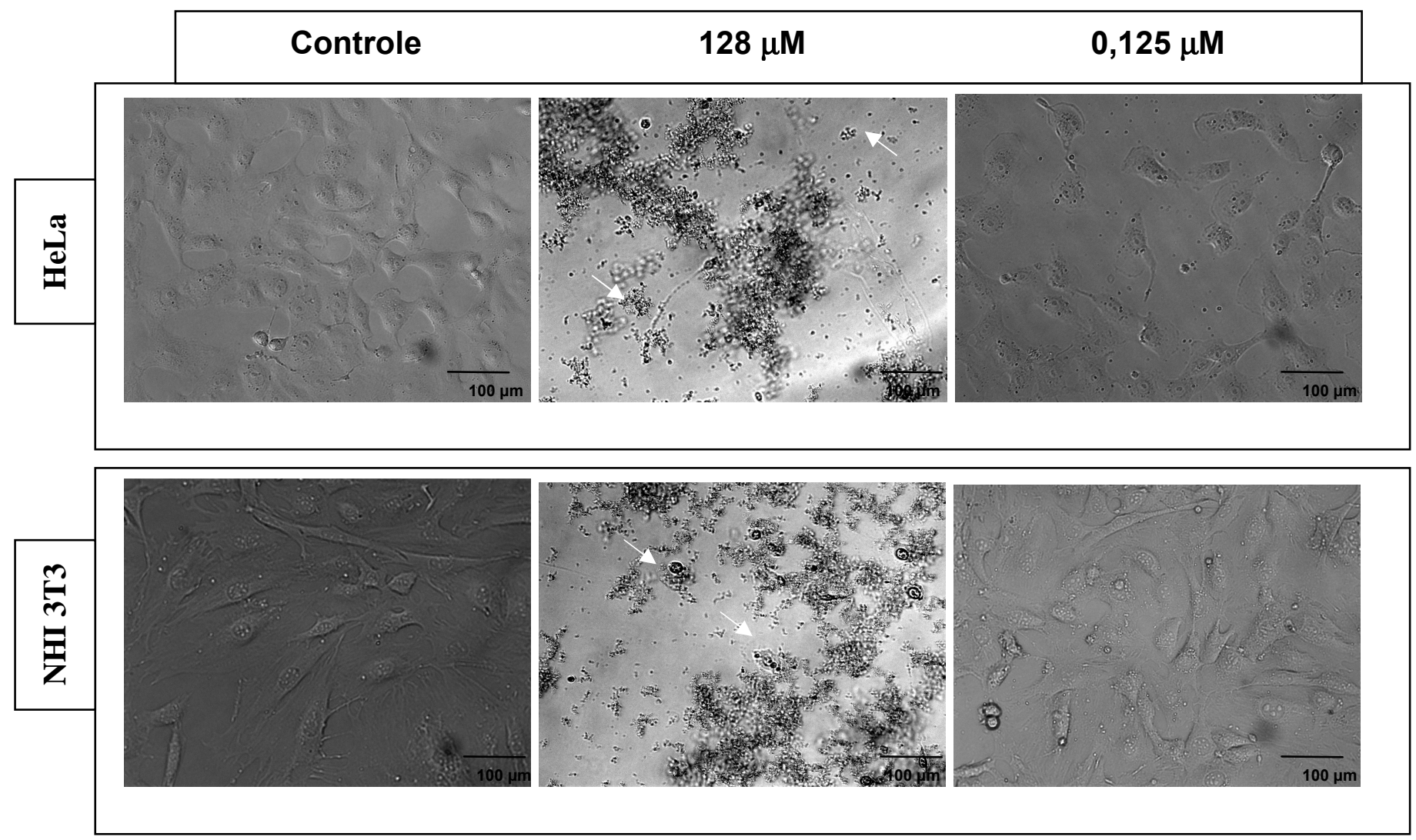

Figura 37. Fotomicrografias das células HeLa (células de câncer de colo do útero, no painel superior) e células NIH-3T3 (células de fibroblastos normais, no painel inferior) e da esquerda para a direita, observa-se o grupo controle (ausência do peptídeo-teste) e os tratamentos com $128 \mu \mathrm{M}$ e $0,125 \mu \mathrm{M}$. Imagens obtidas por microscópio de contraste de fase invertido (UNICO, EUA) com o uso de câmera digital acoplada a ocular do microscópio e o software de aquisição Motic Images Plus 2.0. Barra $=100 \mu \mathrm{m}$. 


\subsection{Determinação da concentração inibitória mínima (MICs) para os peptídeos isolados a partir da secreção bruta de $\boldsymbol{P}$. nattereri}

No presente estudo, foi possível a purificação de 2 peptídeos provenientes da secreção cutânea de $P$. nattereri. Os dois peptídeos isolados são os que possuem a massa molecular de $3180 \mathrm{Da}$ (nattererina 1) e $3208 \mathrm{Da}$ (nattererina 2), respectivamente. Esses dois peptídeos foram testados frente a bactérias Gram-positivas e Gram-negativas de modo a se determinar seus MICs nas condições experimentais descritas anteriormente.

Foi possível observar que os dois peptídeos isolados, tanto a nattererina 1 como a nattererina 2, possuem atividades quase que semelhantes frente as linhagens bacterianas Gram-negativas (Tabela 9) e Gram-positivas (Tabela 10).

Tabela 9. Atividade antimicrobiana e determinação da concentração mínima inibitória (MICs) dos 2 peptídeos purificados a partir da secreção cutânea do anuro $P$. nattereri frente a linhagens bacterianas Gram-negativas.

\begin{tabular}{ccc} 
Peptídeo & $\begin{array}{c}\text { MIC }(\mu \mathrm{M}) \\
\text { Escherichia coli }\end{array}$ & $\begin{array}{c}\text { MIC }(\mu \mathrm{M}) \\
\text { Klebsiella pneumoniae }\end{array}$ \\
\hline Nattererina 1 (3180 Da) & 16 & 32 \\
\hline Nattererina 2 (3208 Da) & 32 & 32 \\
\hline
\end{tabular}

Tabela 10. Atividade antimicrobiana e determinação da concentração mínima inibitória (MICs) dos 2 peptídeos purificados a partir da secreção cutânea do anuro $P$. nattereri frente a linhagens bacterianas Gram-positivas.

\begin{tabular}{ccc}
\hline Peptídeo & $\begin{array}{c}\text { MIC }(\mu \mathrm{M}) \\
\text { Staphylococcus } \\
\text { aureus }\end{array}$ & $\begin{array}{c}\text { MIC }(\mu \mathrm{M}) \\
\text { Enterococcus faecalis }\end{array}$ \\
\hline Nattererina 1 (3180 Da) & 128 & 128 \\
\hline Nattererina 2 (3208 Da) & 128 & 64 \\
\hline
\end{tabular}


Avaliação dos efeitos citotóxicos e antiproliferativos da secreção cutânea e de peptídeos bioativos do anuro Physalaemus nattereri (Steindachner, 1863)

6. Discussão 


\section{Discussão}

Várias pesquisas nos últimos anos têm abordado o potencial das secreções cutâneas de anuros como fontes de agentes antiproliferativos. Pesquisa recente (Sciani et al., 2013) relatou os efeitos deletérios da secreção cutânea bruta de anuros (Rhaebo guttatus, Rhinella margaritifera ePhyllomedusa hypocondrialis) no tratamento do câncer de mama (linhagens MDA-MB-231 e MCF-7) provocando a parada do ciclo celular, redução na proliferação celular e a apoptose.

Outro estudo realizado por Schmeda-Hirschmann et al. (2014) revela um pronunciado efeito antiproliferativo do veneno bruto de Rhinella schneideri sobre linhagens celulares de fibroblastos de pulmão (MRC-5), células epiteliais gástricas humanas (AGS), cancêr de pulmão (SK-MES-1), carcinoma da bexiga (J82) e células de leucemia promielocítica (HL-60), com valores de $\mathrm{IC}_{50}$ variando de 0, 041 a $0,102 \mu \mathrm{g} / \mathrm{mL}$.

Além disso, outros estudos descrevem o uso de extratos aquosos da pele e glândulas parótidas de Bufo gargarizans (sinônimo Bufo bufo gargarizans). Foi descoberto que esses extratos podem inibir a proliferação celular de linhagens celulares de carcinoma de fígado HepG2 e Bel-7402, induzindo apoptose por meio da interrupção do potencial de membrana mitocondrial (Qi et al., 2010). Outros estudos com o veneno bruto e seus principais bufadienolídeos mostrou um efeito indutor de apoptose relevante de cinobufacini em células de leucemia humana U937 e HL-60, carcinoma humano hepatocelular Bel-7402 e linhagens de células HepG2 (Qi et al., 2011).

Em outro trabalho (Giri et al., 2006) foi relatado o efeito de agentes citotóxicos, ação antiproliferativa e indução de apoptose com o uso de extratos obtidos da pele de Duttaphrynus melanostictus (anteriormente Bufo melanostictus) sobre células U937 de leucemia humana mielóide e células K562. Da mesma forma, estudos feitos por Ferreira et al. (2013), utilizando extratos do veneno de Rhinella marina, mostrou uma maior atividade citotóxica contra a leucemia (HL-60), carcinoma de cólon (HCT-116), carcinoma de ovário (OVCAR-8) e glioblastoma (SF295). 
Outros compostos ainda presentes na pele de anfíbios têm sido reportado pelo seu potencial antitumoral. Como, por exemplo, esteróides bufadienolídicos, encontrados em espécies de sapo do gênero Rhinella (ex-Bufo no Novo Mundo), foram eficientes contra a proliferação de células cancerosas in vitro (Toledo et al., 1995; Nogawa et al., 2001; Shaw et al., 2009). Novas investigações sobre bufadienolídeos levou ao isolamento de marinobufagina, bufalina, telocinobufagina, hellebrigenina e cinobufagina, que têm se mostrado eficientes no combate ao câncer de colon, câncer de mama e leucemia (Zhang et al., 1992; Ogasawara et al., 2001; Nogawa et al., 2001; Ye et al., 2005 e Cunha-Filho et al., 2010).

Os mecanismos de ação antitumorais dos bufadienolídeos incluem o desencadeamento de apoptose, regulação da resposta imune, diminuição da angiogênese, e a reversão de resistência a multi-droga (Yeh et al., 2003, e Cunha-Filho et al., 2010).

Outros estudos que descrevem os efeitos dos esteróides bufadienolídicos sobre células tumorais já foram descritos. Bufalina, por exemplo, provoca a apoptose das células por meio de um efeito específico sobre a topoisomerase II e genes relacionados com apoptose, bcl-2, indicando o seu enorme potencial como um novo agente antitumoral (Hashimoto et al., 1997; Kamano et al., 1998; e Krenn e Kopp, 1998). Telocinobufagina também apresenta citotoxicidade em algumas linhagens de células tumorais humanas, tais como a leucemia (HL-60), glioblastoma (SF-295), cólon (HCT-8), e melanoma MDA-MB-435, bem como em linfócitos do sangue periférico humano (PBL) (Cunha-Filho et al., 2010).

Os ensaios descritos no presente trabalho utilizando o método MTT mostraram que tanto a secreção bruta de $P$. nattereri como os peptídeos nattererinas reduzem a viabilidade das linhagens tumorais de forma dose-dependente (Figuras 13, 14, e 15).

De acordo com as análises pode ser observado que houve uma diminuição significativa na viabilidade das células tumorais da linhagem B16F10 em comparação com o controle (fibroblastos normais), sugerindo que a secreção bruta interfere com a proliferação de células B16F10 (Figura 16). Consequentemente, muitas das células observadas exibiram alterações morfológicas graves. Estes resultados indicam que à secreção bruta de $P$. nattereri induz efeitos antiproliferativos ou citotóxicos sobre estas células. 
Também foi observado que, após o tratamento de $24 \mathrm{~h}$, utilizando os peptídeos isolados de $P$. nattereri, na concentração do $I_{50}$ frente à linhagem tumoral HeLa e fibroblastos normais (NIH-3T3) foi evidenciado uma atividade citotóxica em células HeLa mais pronunciadas em comparação com fibroblastos normais (Figura 34, 35, e 36). Ainda observando a morfologia dessas células (Figura 37) percebem-se alterações morfológicas evidentes que serão discutidas de forma aprofundada mais adiante.

Estudos reportam que as secreções de anfíbios induzem a alterações acentuadas na forma das células, em alguns casos relatam também a ocorrência de descolamento da superfície, que indicam apoptose. A secreção cutânea bruta de $P$. nattereri induziu apoptose em células de melanoma, o que levou a alterações morfológicas características do presente processo (Figura 16).

De acordo com Boleti et al. (2008), alterações morfológicas, tais como arredondamento e encolhimento celular, são consistentes com a morte celular por apoptose. Estas características foram observadas no seu estudo sobre a citotoxicidade da pouterina proteína semelhante à lectina, utilizando linhagens tumorigênicas e não tumorigênicas de mamíferos, o que conduziu à conclusão de que a proteína pouterina induz apoptose em células tratadas.

Os experimentos realizados no presente estudo empregando como marcadores com anexina e iodeto de propídio mostraram uma diminuição real da contagem de células não-marcadas (Figura 18). Consequentemente, foi observado um maior número de células marcadas com anexina- $V$ após o tratamento com a secreção cutânea bruta, indicando um estágio precoce da apoptose.

Simultaneamente, verificou-se um aumento discreto em células com dupla marcação $\left(\right.$ Anexina $\left.-\mathrm{V}^{+} / \mathrm{PI}^{+}\right)$, revelando a presença de células que sofreram necrose, o que é comum ocorrer como consequência da permeabilização da membrana celular provocado pelos componentes da secreção cutânea bruta, tais como peptídeos ativos sobre a membrana plasmática.

Apesar da citotoxicidade observada sobre células normais da linhagem NIH-3T3, a secreção cutânea bruta ainda pode ser considerada como uma alternativa para o tratamento de melanoma, uma vez que as células de melanoma foram cerca de 4 vezes mais susceptíveis à exposição ao veneno. 
Algumas estratégias que aumentam a seletividade poderiam ser utilizados como mecanismo para reduzir os efeitos colaterais da secreção bruta, focalizando para o tumor por meio da utilização de veículos de entrega, como lipossomas ou vírus de tal forma que eles se ligassem especificamente a anticorpos de células tumorais (Enbach e Laakkonen, 2007; Guo et al., 2008).

A investigação do mecanismo de ação envolvido na morte das células de melanoma revelou que as células tratadas com a secreção cutânea bruta tinham o seu potencial de membrana mitocondrial reduzido (Figura 19). Alguns peptídeos antimicrobianos interagem com membranas bacterianas, que possuem uma semelhança estrutural com a membrana mitocondrial externa (Kim et al., 2003). Alguns fatores que induzem apoptose existentes no espaço inter-membranar mitocondrial podem ser liberados (Ott et al., 2002) e acredita-se que muitos deles são responsáveis pela iniciação de apoptose. Tal mecanismo tem sido observado no modo de ação de alguns peptídeos anticâncer (Ellerby et al., 1999; Chen et al., 2001).

O ciclo celular é caracterizado por uma série de eventos que conduzem à célula para a replicação de DNA e divisão celular. Novos agentes que possam inibir a transição do estado de quiescência (fase G0) para as fases de crescimento celular e proliferação são promissoras alternativas para o tratamento de tumores malignos.

Baseada nesta premissa, no presente trabalho, foi demonstrado que a secreção cutânea bruta $P$. nattereri é capaz de inibir a proliferação de células da linhagem celular de melanoma, induzindo a parada do ciclo celular na fase $S$ (Figura 20), reduzindo assim o número de células na fase G2/M.

De acordo com Arellano e Moreno (1997), a progressão do ciclo celular é controlada por vários complexos ciclina/CDK. Outros estudos têm mostrado que, além da inibição da ciclina A/CDK2, A atividade de quinase, a expressão da p21 e ativação inapropriada de genes E2F-1 podem também serem responsáveis pela interrupção do ciclo na fase S (Zhang et al., 2000; Zhu et al., 2004).

No entanto, o mecanismo exato que provoca a redução da viabilidade celular e citotoxicidade após tratamento com o veneno bruto de $P$. nattereri ainda é desconhecido. A apoptose é uma via fisiológica de morte celular submetida a processos de regulação complexos. Deste modo, novas estratégias capazes de 
induzir o processo de apoptose em células cancerosas seriam bem interessantes no tratamento de tumores. (Okada \& Mak, 2004).

Por outro lado, uma vez que a secreção cutânea bruta de $P$. nattereri induz a parada do ciclo celular em células de melanoma murino, ela poderia ser empregada com o intuito de potencializar a citotoxicidade dos agentes quimioterapêuticos que desregulam o ciclo celular já empregados na terapia do câncer.

Uma grande quantidade de PAMs já foram isolados de anuros e vários deles são eficazes como agentes anticâncer (Libério et al. 2011) descreveram a atividade citotóxica e antiproliferativa da ocellatin-P1 (pentadactylina), um peptídeo isolado a partir da secreção da rã Leptodactylus labyrinthicus (Leptodactylidae). Os resultados mostraram que a pentadactylina reduz a viabilidade das células tumorais de melanoma murino (B16F10) de um modo dose-dependente com indícios de que seus efeitos citotóxicos ocorreria pela via apoptótica.

Um estudo realizado por van Zoggel, et al, (2012) mostraram que dermaseptinas sintéticas B2 e B3, isoladas a partir de Phyllomedusa bicolor (Hylidae), são capazes de inibir a proliferação da linhagem celular de adenocarcinoma prostático humano $\mathrm{PC}-3 \mathrm{com}$ um discreto ou quase nenhum efeito sobre as células de fibroblastos murinos normais NIH-3T3. Além disso, efeito angiostático foi observado quando as dermaseptinas foram testadas em células endoteliais aórticas de bovinos adultos (ABAE).

Em um estudo realizado por Wang et al. (2012), uma temporina-1CEa sintética extraída a partir da secreção cutânea de Rana chensinensis (Ranidae) apresentou efeito citotóxico para as doze linhagens celulares de carcinoma humano de maneira dose-dependente, e o efeito mais pronunciado foi observado sobre células MCF-7. A temporina-1CEa também apresentou baixo efeito hemolítico em eritrócitos humanos e não apresentou citotoxicidade significativa para células humanas normais do músculo liso de veia umbilical (HUVSMCs) considerando as concentrações antitumorais eficazes.

Wang et al. (2013) demonstraram que o peptídeo temporina-1CEa provoca morte celular rápida em MDA-MB-231 e células tumorais de câncer de mama MCF-7 por meio de um mecanismo mediado pela destruição da membrana plasmatica e dependente de cálcio intracelular. 
Um peptídeo sintético Hymenochirina-1Pa, isolado de Pseudhymenochirus merlini (Pipidae), mostrou elevada atividade citotóxica sobre células humanas de adenocarcinoma do pulmão A549, adenocarcinoma de mama MDA-MB-231, adenocarcinoma de colo-retal HT-29, embora tenha apresentado ainda moderada atividade hemolítica contra eritrócitos humanos, não sendo seletivo para células tumorais (Serra et al., 2014).

Em comparação com o grande número de PAMs que já foram isolados de anfíbios, poucas pesquisas têm sido realizadas para avaliar a citotoxicidade destes peptídeos contra células cancerosas e seu mecanismo de ação (Cruz-Chamorro et al., 2006). Além da função antimicrobiana dos peptídeos catiônicos purificados a partir de anfíbios, muitas evidências indicam a sua utilização na terapia do câncer, uma vez que os PAMs apresentam potente atividade contra células tumorais, são imunogênicos e pequenos, reduzindo os custos de sua síntese.

Estudos sobre o mecanismo de ação, bem como o desenvolvimento de estratégias capazes de aumentar a potência, seletividade, e resistência a componentes do soro pode representar um importante avanço em modelos terapêuticos (Kim et al., 2003; Shadidi \& Sioud 2003; e Cruz-Chamorro et al., 2006).

Alcalóides também têm sido descritos pela sua atividade antitumoral e podem ser utilizados em alguns tratamentos contra o câncer (Cholewinski, et al., 2011).

A vinorelbina, um alcalóide atualmente utilizado no tratamento do câncer de mama, por exemplo, é mais frequentemente administrada como terapia de segunda ou terceira linha em pacientes com doença metastática (Higa et al., 2011). Estudos que determinem a presença de alcalóides na secreção cutânea de $P$. nattereri também são necessários para validar um possível mecanismo de ação neste sentido.

De modo geral, em relação à secreção cutânea bruta de $P$. nattereri foram analisadas diversas possibilidades que indicam que esta secreção induz a acentuados efeitos deletérios sobre células de melanoma murino (B16F10). De acordo com os resultados apresentados na presente tese, reforçam fortemente a validade de secreção bruta de $P$. nattereri como uma fonte rica de novas moléculas antitumorais.

Existem vários mecanismos através dos quais o veneno e os seus componentes são capazes de iniciar os processos citotóxicos ou antiproliferativos e 
outros estudos utilizando componentes isolados do veneno são necessários para avaliar quais as vias de morte celular são ativadas por cada componente.

$O$ fracionamento de venenos de origem animal com a finalidade de prospecção molecular é comumente realizado com o emprego da cromatografia líquida de alta eficiência em colunas de fase reversa tipo $\mathrm{C}_{18}$ (RP-HPLC) como etapa inicial. A cromatografia de fase reversa é baseada na hidrofobicidade das moléculas a serem analisadas, e não na polaridade das mesmas, como é observado na cromatografia de fase normal (Joseph \& Marsden, 1986).

É bom salientar que a cromatografia de fase reversa pode ser utilizada tanto em escala analítica como preparativa. Moléculas que possuem algum grau de hidrofobicidade, tais como proteínas, peptídeos, ácidos nucléicos, compostos orgânicos de baixa massa molecular, podem ser rapidamente fracionadas (Palma et al., 2007) e, em seguida, analisadas por espectrometria de massas.

Nos últimos anos, a espectrometria de massas revolucionou o estudo de proteínas e peptídeos, proporcionando identificação rápida e com alta sensibilidade de amostras procedentes de géis $1 \mathrm{D}, 2 \mathrm{D}$ e de cromatografias líquidas em sistema HPLC. As vantagens na identificação de moléculas empregando-se a espectrometria de massas incluem: alta sensibilidade na escala de fentomoles, identificação de várias proteínas em uma amostra, checagem da pureza de proteínas e peptídeos, identificação de isoformas protéicas, quantificação de cisteínas e localização de pontes dissulfeto, seqüenciamento de proteínas, identificação de proteínas em análise de proteomas, pesquisa de novas drogas (Cunha et al., 2006; Palma et al., 2007).

Devido à sua complexidade e diversidade, as secreções cutâneas dos anuros representam uma fonte abundante de compostos bioativos (principalmente de natureza peptídica ou protéica) e, graças ao desenvolvimento de novas tecnologias, tem sido possível a realização de estudos na área de Toxinologia com pequenas quantidades dessas secreções (Favreau et al., 2006).

A secreção cutânea do anuro $P$. nattereri em termos de conteúdo peptídico já foi alvo de pesquisa dentro do nosso grupo. Tal secreção apresenta um perfil cromatográfico bastante rico quimicamente resultando em uma média de 130 frações eluídas por RP-HPLC em coluna $C_{18}$ (Figuras 21). Sabe-se que as secreções glandulares de anuros são ricas em componentes moleculares com 
Avaliação dos efeitos citotóxicos e antiproliferativos da secreção cutânea e de peptídeos bioativos do anuro Physalaemus nattereri (Steindachner, 1863)

variadas funções farmacológicas, destacando-se uma grande quantidade de análogos de hormônios de mamíferos e peptídeos com atividade antimicrobiana (Castro et al., 2009).

De acordo com Zheng e colaboradores (2005), o perfil peptídico da secreção cutânea de anfíbios possui o potencial de ser utilizado para a elucidação de questões de taxonomia biológica, já que o perfil peptídico da secreção de espécimes da mesma espécie é significativamente similar e, entre espécies do mesmo gênero, existe alguma similaridade.

Outra importante aplicação do perfil peptídico é na identificação de peptídeos funcionais comuns entre diferentes espécies. Entretanto, essa metodologia é limitada para peptídeos sem pontes dissulfeto com massa molecular entre 300 a 4.000 Da (Favreau et al., 2006).

As frações resultantes do fracionamento cromatográfico da secreção cutânea de $P$. nattereri foram submetidas a ensaios biológicos para avaliação de diferentes atividades biológicas, como antitumoral, antimicrobiana, antifúngica e hemolítica. Tais ensaios foram realizados inicialmente como ensaios de varreadura (screening) e conduziram à identificação das frações cromaotgráficas semi-purificadas com atividade inibitória sobre a proliferação das bactérias testadas (Gram-positiva $S$. aureus e Gram-negativa E. cloacae) (Tabela 4). Também foi possível constatar que tais frações (nas mesmas concentrações empregadas nos ensaios antibacterianos) não exibiram atividade hemolítica.

Também foram realizados ensaios de varredura no intuito de se identificar frações com atividade inibitória sobre a proliferação dos fungos patogênicos Candida albicans e Crytococcus neoformans (Tabelas 5 e 6). A identificação dessas frações foi extremamente importante, pois revelou tratarem-se das mesmas frações com atividade inibitória sobre as bactérias patogênicas testadas.

De acordo com os resultados obtidos por Zelezetsky et al. (2005), pequenas alterações nas características químicas do peptídeo, como tamanho da face polar, profundidade do setor hidrofóbico e o gradiente longitudinal de hidrofobicidade, podem produzir grandes impactos na atividade biológica. As diferenças de potência observadas nos ensaios antimicrobianos realizados com as bactérias $S$. aureus $e$ E. cloacae (Tabela 4) estão provavelmente relacionadas às diferenças na composição da parede celular de bactérias Gram-negativas e Gram-positivas. 
A parede celular bacteriana é um obstáculo a ser ultrapassado pelos peptídeos antimicrobianos, pois dificulta o acesso à superfície com cargas negativas da membrana. Uma vez vencidas as barreiras de acesso à membrana, é necessária a interação com a superfície negativamente carregada e o acúmulo de uma concentração limiar de peptídeos para que estes possam atuar na camada lipídica (Yeaman \& Yount, 2003).

Desta maneira, os ensaios evidenciaram uma diferença significativa na atividade biológica desses peptídeos frente às bactérias Gram-positivas e Gram-negativas testadas.

As propriedades antimicrobianas e citolíticas dos peptídeos são determinadas pela complexa interação entre cationicidade, hidrofobicidade, capacidade de adotar a conformação $\alpha$-hélice anfipática (Yeaman \& Yount 2003). Dessa forma, estudos demonstram que a conformação em $\alpha$-hélice anfipática é fundamental para a toxicividade contra bactérias Gram-positivas, mas menos necessária contra Gram-negativas (Giangaspero et al., 2001).

Desde que a cationicidade e a hidrofobicidade sejam mantidas, peptídeos com pouca anfipaticidade ainda são ativos, como é observado nos peptídeos de Leptodactylus. Semelhantemente, foi demonstrado que o aumento do momento hidrofóbico promove a atividade hemolítica contra eritrócitos humanos (Dathe \& Wieprecht, 1999).

A comparação e a compreensão desses parâmetros podem auxiliar no desenho de novos antibióticos, suprindo a urgente necessidade de novos fármacos para combater linhagens de microrganismos resistentes (Oren et al., 1999).

Considerando a especificidade das bactérias para certas doenças, onde: $S$. aureus causa doenças de pele e infecções alimentares e $E$. cloacae é agente causador de infecções urinárias e respiratórias, o grande número de peptídeos com possível atividade antimicrobiana encontrado em cada espécie vai de encontro com a idéia de que tais peptídeos, apesar de apresentarem um amplo espectro de ação são muitas vezes seletivos a um determinado grupo de microrganismos, como demonstrado para as dermaseptinas encontradas em $P$. sauvagei e P. hypochondrialis (Mor et al., 1994, Brand et al., 2006a). 
A possibilidade de uma ação sinergística entre PAMs e uma expressão induzida pelo contato com determinados patógenos possibilita uma defesa mais eficaz contra um maior número desses organismos (Mor et al., 1994).

A ação sinergística entre peptídeos da mesma família já foi descrita anteriormente (Mor et al., 1994). Considerando a crescente dificuldade de conter infecções rotineiras em humanos, animais e plantas, o estudo de peptídeos antimicrobianos conduz para um novo campo de produção de fármacos com objetivo de conter o avanço de patógenos multirresistentes (Morton et al., 2007).

Em relação à similaridade com outros peptídeos antimicrobianos, é importante destacar que o peptídeo nattererina $1(3180 \mathrm{Da})$ isolado de $P$. nattereri apresenta $56 \%$ de similaridade com peptídeo antimicrobiano ranateurina-2BYa isolado de Rana boylii (Conlon et al, 2003). As análises estruturais evidenciaram também que a syphaxina, isolada de Leptodactylus syphax (Dourado et al., 2007) e a fallaxina, isolada de Leptodactylus fallax (Rollins-Smith et al., 2005), apresentaram uma similaridade de 60\% com a nattererina 1. Já em relação à nattererina 2 (3208 Da), o peptídeo ranateurina- $1 T$ apresentou $63 \%$ de similaridade, a gaegurina-2 apresentou $60 \%$. Por último, em relação à Nattererina $3(3142 \mathrm{Da})$, a ranateurina-1T exibiu uma similaridade de $60 \%$, a ranateurina-2BYa de $53 \%$. (Honorato, C. T. M. 2009).

Após a identificação dos peptídeos ativos da secreção cutânea do anuro P. nattereri e realização da purificação empregando-se RP-HPLC seguida de análises por espectrometria de massas, estes peptídeos foram avaliados quanto as suas atividades biológicas. Foram então determinadas as concentrações inibitórias mínimas (MICs) sobre bactérias Gram-positivas (S. aureus e E. faecalis) e Gram-negativas (E. coli e K. pneumoniae) (Tabela 9 e 10). Como alguns dos PAMs catiônicos com amplo espectro de ação também são citotóxicos para células de câncer, (e Carvalho, A. C. 2011), as três versões sintéticas do peptídeo de $P$. nattereri foram avaliadas quanto à sua ação anticâncer. Os peptídeos foram então avaliados quanto ao seu potencial citotóxico frente às linhagens HeLa (câncer do colo uterino) e NIH-3T3 (fibroblastos normais). Os resultados obtidos demonstraram que os três peptídeos isolados da secreção de $P$. nattereri são citotóxicos contra céluluas de câncer do colo uterino (Figura 34, 35, e 36). 
Embora muitos dos peptídeos antimicrobianos ativos contra um amplo espectro de microrganismos também desempenham atividade antitumoral (Libério, 2008), poucos estudos foram realizados para a verificação da atividade contra linhagens de câncer e sobre o seu mecanismo de ação como já foi mencionado anteriormente (Cruz-Chamorro et al., 2006).

Freqüentemente, os peptídeos anticâncer possuem o C-terminal amidado, apesar dessa característica não ser uma regra. Todavia, peptídeos pouco catiônicos como, por exemplo, a gaegurina 6 pode ser citotóxicos ou citostáticos contra células carcerígenas (Cruz-Chamorro et al., 2006).

O controle da proliferação celular em células tumorais é considerado uma eficiente estratégia para prevenir ou retardar o crescimento tumoral (Molinari et al., 2000). Estudos detectaram uma maior incidência dos resíduos de aminoácido I e K nos peptídeos anticâncer do que nos peptídeos antimicrobianos (PAMs) e que o balanço inversamente proporcional entre anfifilicidade e hidrofobicidade é importante para os PACs na invasão das membranas celulares das células tumorais (Dennison et al., 2006).

É possível verificar de acordo com a literatura que os PACs menos catiônicos apresentam maior hidrofobicidade média $(<H>)$, contudo, também sugere que, como na atividade antimicrobiana, a atividade anticâncer é decorrente de um sinergismo de características químicas do peptídeo (Dennison et al., 2006).

Os resultados apresentados no presente trabalho mostraram que tanto as nattererinas 1, 2 e 3 como a secreção bruta de $P$. nattereri exibiram atividade anticâncer contra as linhagens celulares testadas. De acordo com os resultados apresentados, as nattererinas tiveram atividade citotóxica sobre células HeLa variando a concentração capaz de inviabilizar $50 \%$ das células $\left(\mathrm{IC}_{50}\right)$ entre 4,54 a $11,57 \mu \mathrm{M}$. No entanto, observou-se uma diferença sobre a atividade desses peptídeos em fibroblastos normais, (NHI-3T3) com um valor de $\mathrm{IC}_{50}$ maior (Tabela 8). No caso do veneno bruto quando testado sobre a linhagem tumoral de melanoma murino (B16F10) apresentou um $\mathrm{IC}_{50}$ menor ao ser compararado com o obtido para a linhagem de fibroblastos (NIH-3T3), com susceptiblidade aproximadamente 4,4 vezes maior em relação aos fibroblastos normais. 
Acredita-se que a interação entre as características do peptídeo e a composição da membrana das células utilizadas é que determina a especificidade e a potência da atividade desempenhada pelo peptídeo (Dennison et al., 2006), o que poderia explicar as diferenças observadas na potência desses peptídeos sobre as células tumorais e normais.

Apesar das três versões sintéticas do peptídeo de $P$. nattereri serem consideradas eficazes podendo vir a ser usados como uma alternativa no combate ao câncer, algumas alterações estruturais devem ser propostas de modo a diminuir os efeitos deletérios sobre células normais.

Pesquisas revelaram que peptídeos análogos compostos de D- e L-aminoácidos possuem a sua especificidade contra células tumorais aumentada, sendo a seletividade provavelmente determinada pela atração eletrostática dos peptídeos aos componentes acídicos (mucinas O-glicosiladas) da superfície das células de câncer, mas podendo ser influenciada pela maior superfície de contato (microvilos) dessas células.

Além da redução da toxicidade, a composição simples desses análogos, a sua estabilidade frente à degradação enzimática e inativação por componentes do soro e a reduzida antigenicidade fazem desses peptídeos excelentes candidatos a novos quimioterápicos (Papo \& Shai, 2003).

Os PACs citotóxicos também para células normais geralmente provocam a morte celular via modelo barrel-stave. Também sabe-se que outra forma de morte de células tumorais causada por PACs é pela formação de poros toroidais, caracterizado pela formação de poros temporários. Enquanto abertos, esses poros também podem permitir a entrada dos peptídeos dentro da célula, atingindo alvos celulares e desencadeando a via apoptótica, assim a ação dos PACs pode ter múltiplos alvos (Dennison et al., 2006).

Resumidamente, a necrose inicia com danos físicos severos à célula, levando à ruptura abrupta da membrana plasmática e à liberação do seu conteúdo citoplasmático (Majno et al., 1995). No entanto, é preciso ter cautela ao associar essa característica somente à necrose. Células em estágios avançados de apoptose são semelhantes às células necróticas. Essa semelhança é de tal ordem que alguns autores sugeriram um termo para caracterizar esse estágio: "necrose apoptótica" (Majno et al., 1995). 
Sendo assim, células na fase final da apoptose também apresentam alterações na estrutura e na função de transporte da membrana plasmática. A morfologia de células apoptóticas é caracterizada pela desidratação e redução do volume e granulosidade celular, ondulações na membrana plasmática, aumento do volume mitocôndrial e fragmentação do material genético (Majno et al., 1995; Darzynkiewicz et al., 1997).

Considerando que a toxicidade para as células normais também é uma característica dos quimioterápicos convencionais, estratégias desenvolvidas para aumentar a sua eficiência também podem ser empregadas no uso desses peptídeos. Dessa forma, uma alternativa poderia ser o direcionamento desses peptídeos anticâncer para a célula tumoral por meio do uso de vetores, como peptídeos que se ligam especificamente a determinadas células tumorais (Enbäch \& Laakkonen, 2007) e vírus (Guo et al., 2008).

Alterações na morfologia celular das linhagens testadas também foram confirmadas pela observação em microscópio de contraste de fase das células tratadas com as três versões sintéticas das nattererinas (Figura 37).

Notou-se que todas as linhagens tratadas com as maiores concentrações dos peptídeos tiveram a sua morfologia celular modificada, isto é bem evidente pela observação da perda da integridade da membrana celular e indefinição do núcleo e do nucléolo. Nas maiores concentrações testadas, foi possível a observação de debris celulares, evidenciando uma forte atividade sobre a membrana dessas células. As células cancerígenas do grupo controle (ausência dos peptídeos) (Figuras 37) apresentaram morfologia bem definida com a membrana citoplasmática integra, núcleo e do nucléolo evidentes e uma morfologia celular poligonal. Podemos avaliar de forma positiva a ação das nattererinas, uma vez que foram capazes de inibir o crescimento da célula cancerígena do colo uterino (HeLa). Sugere-se que os efeitos citotóxicos observados são resultado da ativação da via.

Ainda não se sabe se apoptose, senescência, necrose, autofagia e catástrofe mitótica são situações que acontecem de forma independente ou que se relacionam em algum grau e se ocorrem sucessivamente ou simultaneamente. Um importante aspecto da tumorigenicidade e do desenvolvimento de resistência a drogas anticâncer é a resistência à morte celular, principalmente via apoptose. 
Durante o início do processo apoptótico ocorre perda da assimetria dos fosfolipídeos da membrana plasmática, levando à exposição de fosfatidilserina na face externa, tornando a membrana mais suscetível à desestabilização pelo peptídeo, levando à necrose da célula.

A perda da integridade da membrana observada sob altas concentrações de PAMs pode indicar o mecanismo de ação carpet-like, pois pode ser que a destruição da membrana dependa da concentração de peptídeos ligados atingirem um limiar específico, levando ao colapso com inúmeros poros toroidais formados (Dennison et al., 2006). Esse mecanismo de ação (carpete/poro toroidal) foi recentemente descrito para o peptídeo melittina (Allende et al., 2005).

Outro mecanismo pelo qual as células tratadas poderiam perder a sua integridade de membrana seria pelo modelo Shai-Matsuzaki-Huang, no qual ocorre um "estreitamento" da membrana seguido da formação de poros transientes e colapso da membrana. Nesse caso, os poros também permitiriam que os peptídeos atingissem alvos intracelulares capazes de desencadearem o processo apoptótico antes da desintegração da membrana (Dennison et al., 2006).

Assim, novas estratégias capazes de induzir o processo apoptótico em células de câncer são estratégicas, uma vez que modulam a sensibilidade do tumor e das células normais aos agentes antitumorais, via os mecanismos regulatórios da apoptose (Okada \& Mak, 2004).

Além do papel antimicrobiano dos peptídeos catiônicos de anuros, várias evidências já indicam o seu uso na terapêutica do câncer, visto que os peptídeos anticâncer apresentam uma potente atividade contra células tumorais, são pouco imunogênicos e são pequenos, reduzindo os custos da síntese. Uma vez que nada adianta ser ativo e potente quando o alto custo inviabiliza sua produção em larga escala.

Vale ressaltar que os experimentos realizados no presente estudo empregram modelos in vitro, portanto o desempenho desses peptídeos anticâncer pode ser totalmente alterado nos ensaios in vivo, indicando várias etapas futuras na avaliação do potencial terapêutico desses peptídeos. 
Avaliação dos efeitos citotóxicos e antiproliferativos da secreção cutânea e de peptídeos bioativos do anuro Physalaemus nattereri (Steindachner, 1863)

Embora, o mecanismo específico envolvido na redução da viabilidade celular e citotoxicidade após o tratamento com essa secreção bruta ainda não seja conhecido, podemos supor que a atividade de moléculas, como peptídeos, presentes nessa secreção seja efetivos contra as células de melanoma murino (B16F10). Considerando-se a necessidade crescente por novas drogas anticâncer, o presente estudo fortemente reforça a validade do uso da secreção cutânea de $P$. nattereri como uma rica fonte de novas moléculas anticâncer, principalmente peptídeos. 
Avaliação dos efeitos citotóxicos e antiproliferativos da secreção cutânea e de peptídeos bioativos do anuro Physalaemus nattereri (Steindachner, 1863)

7. Conclusão 


\section{Conclusões}

Este trabalho teve como propósito ampliar o conhecimento acerca das propriedades citotóxicas e composição bioquímica da secreção cutânea do anuro $P$. nattereri comumente encontrado na fauna do Cerrado brasileiro. No presente estudo constatou-se a enorme riqueza peptídica presente na secreção cutânea desse anuro. Toda essa variedade possui relevante potencial para o desenvolvimento de novas drogas, principalmente contra bactérias e células tumorais resistentes aos fármacos convencionais.

A estratégia experimental adotada revelou-se eficiente no fracionamento de uma secreção cutânea com uma grande diversidade de componentes moleculares. Tal fracionamento permitiu constatar a grande diversidade de moléculas neste veneno, com a eluição de aproximadamente 130 frações que foram analisadas por espectrometria de massas do tipo MALDI-TOF, resultando na detecção de diversos componentes com massas moleculares distintas.

Pelo menos dois peptídeos antimicrobianos foram isolados e caracterizados biologicamente neste trabalho, as nattererinas 1 e 2 (3180 Da e $3208 \mathrm{Da})$. As duas nattererinas apresentaram efeitos biológicos relevantes com atividade antiproliferativa sobre bactérias Gram-positivas ( $S$. aureus e E. faecalis) e Gramnegativa ( $E$. coli e K. pneumoniae). Pelo menos três frações cromatográficas foram identificadas por exibir atividade inibitória sobre a proliferação das leveduras Cryptococcus neoformans e Candida albicans.

Dentre os peptídeos antimicrobianos identificados no presente estudo, 3 peptídeos (as nattererinas 1, e 2, e 3 ) foram sintetizados e testados quanto aos seus efeitos tóxicos sobre a linhagem tumoral HeLa.

As nattererinas apresentaram atividade citotóxica contra câncer do colo uterino (HeLa), exibindo valores de $\mathrm{IC}_{50}$ que variarm de 4,54 $\mu \mathrm{M}$ a $11,57 \mu \mathrm{M}$, assim como efeitos inibitórios sobre a proliferação de bactérias patogênicas com MICs entre 16 e $128 \mu \mathrm{M}$. 
No caso da avaliação das propriedades citotóxicas e antiproliferativas dessa secreção, contatou-se que a linhagem tumoral B16F10 (câncer de melanoma murino) é mais suscetível ao veneno bruto de $P$. nattereri, apresentando um valor de $\mathrm{IC}_{50}$ igual a $0,51 \mu \mathrm{g} / \mathrm{mL}$ enquanto que para linhagem tumoral HeLa o valor de $\mathrm{IC}_{50}$ foi igual a $23,04 \mu \mathrm{g} / \mathrm{mL}$.

A avaliação dos efeitos citotóxicos e antiproliferativos da secreção bruta de $P$. naterreri sobre a linhagem de células de melanoma murino B16F10 foi aprofundada, comparando-se os efeitos tóxicos observados na linhagem tumoral com aqueles promovidos sobre células normais (fibroblastos murinos da linhagem $\mathrm{NIH}-3 \mathrm{~T} 3$ ).

Ensaios adicionais de citometria de fluxo revelaram que a secreção bruta de $P$. naterreri não interfere de forma significativa nas etapas do ciclo celular, os resultados indicaram algumas poucas diferenças nas fases do ciclo celular de células não-tratadas e tratadas. Verificou-se um incremento de 3,24\% na proporção de células na fase S (síntese) e uma diminuição de 4,94\% na proporção de células na fase G2/M, mostrando que houve uma "tendência" a parada do ciclo celular em células tratadas com o veneno.

A investigação da influência do veneno de $P$. nattereri no potencial de membrana mitocondrial foi realizada através das análises das características funcionais das mitocôndrias e foi verificado que a secreção cutânea bruta induziu alterações significativas afetando 0 potencial de membrana mitocondrial, reduzindo-o. As células tratadas com o veneno tiveram seu potencial de membrana mitocondrial reduzido em $4,53 \%$.

Já o tratamento das células tumorais de melanoma com a secreção bruta de $P$. nattereri promoveu alterações no padrão de exposição de fosfatidilserina (revelado com anexina- $\mathrm{V}^{+}$) e na permeabilidade da membrana plasmática (revelada com iodeto de propídeo, $\mathrm{PI}^{+}$). Vale destacar que houve um aumento de $41,26 \%$ no número de células marcadas apenas com anexina- $\mathrm{V}^{+}$e que não foram observadas diferenças significativas no número de células marcadas exclusivamente com iodeto de propídeo. Além disso, detectou-se um aumento na fragmentação do DNA das células B16F10 quando expostas ao veneno, sugerindo que a morte celular ocorra por meio de apoptose. Mais estudos precisam ser realizados a fim de se determinar o mecanismo pelo qual a secreção bruta de $P$. natererri promove a morte das células 
Avaliação dos efeitos citotóxicos e antiproliferativos da secreção cutânea e de peptídeos bioativos do anuro Physalaemus nattereri (Steindachner, 1863)

tumorais, mas existem indícios fortes de que o processo apoptótico esteja seja ativado na presença da secreção de $P$. nattereri. 
Avaliação dos efeitos citotóxicos e antiproliferativos da secreção cutânea e de peptídeos bioativos do anuro Physalaemus nattereri (Steindachner, 1863)

$\underline{\text { 8. Considerações Finais }}$ 


\section{Considerações Finais}

A descoberta de novas moléculas antitumorais é de extrema importância principalmente em virtude do surgimento de resistência aos quimioterápicos disponíveis no mercado. A síntese química constitui uma alternativa para obtenção de quantidades moderadas desses peptídeos ainda que a sua obtenção em larga escala ainda seja bastante onerosa.

Entretanto, por meio dessa metodologia é possível a realização de experimentos que permitam analisar e determinar muitos parâmetros importantes para a atividade antimicrobiana/anticâncer, facilitando assim o desenvolvimento de alternativas menos dispendiosas para o controle de doenças baseadas em terapias com peptídeos antimicrobianos/anticâncer.

Um estudo sistemático de bioprospecção dessas moléculas derivadas das screções cutâneas de anuros, com isolamento, síntese química em larga escala e caracterização biológica, possibilitará, não somente um grande avanço na produção de novas drogas, mas também o reconhecimento do valor de cada uma delas, como novas categorias de recursos genéticos e, por fim, reforçará a necessidade de preservação desse importante grupo de animais.

Dessa forma, compostos ativos vêm sendo sintetizados e testados visando à fabricação de drogas de amplo espectro e de múltipla aplicabilidade. Sendo assim, é de extrema relevância a investigação desses compostos, uma vez que podem auxiliar no esclarecimento de questões taxonômicas, na identificação de potenciais drogas terapêuticas e no entendimento da biologia destes animais. 
Avaliação dos efeitos citotóxicos e antiproliferativos da secreção cutânea e de peptídeos bioativos do anuro Physalaemus nattereri (Steindachner, 1863)

\section{Referências Bibliográficas}




\section{Referências bibliográficas}

Arellano M, Moreno S. Regulation of CDK/cyclin complexes during the cell cycle. Int J Biochem Cell Biol v.29: p. 559-573 1997.

Anchiêta Jr. J.J.L. Nanoencapsulação de um peptídeo isolado de rãs : citotoxicidade in vitro em células tumorais humanas e genotoxicidade em Allium cepa e linfócitos sanguíneos humanos. Dissertação de Mestrado em Ciências Farmacêuticas da Universidade Federal do Piauí. 2012.

Ahmad, M.; Piludu, M.; Oppenheim, F.G.; Helmerhorst, E.J.; Hand, A.R. Immunocytochemical localization of histatins in human salivary glands. J. Histochem. Cytochem. 52, 361-370. 2004.

AICR (American Institute for Cancer Research). Food, Nutrition, Physical Activity, and the Prevention of Cancer: a Global Perspective. Washington: American Institute for Cancer Research. p. 517, 2007.

Alanis, A. J. Resistance to antibiotics: are we in the post-antibiotic era? Arch Med Res, v. 36, n. 6, p. 697-705, 2005.

Allende, D., Simon, S. A., Mcintosh, T. J. Melittin-induced bilayer leakage depends on lipid material properties: evidence for toroidal pores. Biophys. J. v. 88, p. 1828-1837, 2005.

Almeida, V. L., Leitão, A., Reina, L. C. B., Montanari, C. A., Donnici, C. L., Lopez, M. T. P. "Cancer e agentes antineoplásicos específicos e ciclo-celular não específicos que interagem com o DNA: uma introdução" Quim. Nova. v. 28, p. 118-129, 2005. 
Avaliação dos efeitos citotóxicos e antiproliferativos da secreção cutânea e de peptídeos bioativos do anuro Physalaemus nattereri (Steindachner, 1863)

Arason VA, Dristinsson KG, Sigurdsson JA, Stefánsdóttir G, Mölstad S, Gudmundsson S. Do antimicrobials increase the carriage rate of penicillin resistant pneumococci in children? Cross sectional prevalence study. British Medical Journal 313:387-390, 1996.

Austin, D. J., Kristinsson, K. G. E Anderson, R. M., Proc. Natl. Acad. Sci. USA, 96:1152- 1156. 1999.

Bartlett, T. C. J. Cuthbertson, E. Shepard, R. Chapman, P. Gross, G. Warr. Crustins, homologues of an $11.5-\mathrm{kDa}$ antibacterial peptide, from two species of penaeid shrimp, Litopenaeus vannamei and Litopenaeus setiferus. Biotechnol (NY), v. 4, n. 3, p. 278-93, 2002.

Bechinger, B. The structure, dynamics and orientation of antimicrobial peptides inmembranes by multidimensional solid-state NMR spectroscopy. Biochim. Biophys.Acta. v. 1462, p. 157 - 183, 1999.

Bello, A. L. et al. Nosocomial infections: knowledge and source of information among clinical health care students in Ghana. Int J Gen Med, v. 4, p. 571-574, 2011.

Bergman, P.; Johansson, L.; Wan, H.; Jones, A.; Gallo, R.L.; Gudmundsson, G.H.; Hokfelt, T.; Jonsson, A.B.; Agerberth, B. Induction of the antimicrobial peptide cramp in the blood-brain barrier and meninges after meningococcal infection. Infect. Immun. V. 74, p. 6982-6991. 2006.

Bhutia, S. K. \& Maiti, T. K. Targeting tumors with peptides from natural sources. Trends Biotechnol. v. 26, p. 210-217, 2008.

Brand, G. D., Leite, J. R., De Sá Mandel, S. M., Mesquita, D. A., Silva, L. P.,Prates, M. V., Barbosa, E. A., Vinecky, F., Martins, G. R., Galasso, J. H., Kuckelhaus, S. A., Sampaio, R. N., Furtado, J. R. Jr., Andrade, A. C., Bloch, C. Jr. Novel dermaseptins from Phyllomedusa hypochondrialis (Amphibia). Biochem Biophys Res Commun. V. 347, p. 739-46, 2006a. 
Avaliação dos efeitos citotóxicos e antiproliferativos da secreção cutânea e de peptídeos bioativos do anuro Physalaemus nattereri (Steindachner, 1863)

Brandão, H. N., David, J. P., Couto, R. D., Nascimento, J. A. P., David. J. M., Química e Farmacologia de Quimioterápicos Antineoplásicos Derivados de Plantas. Quim. Nova. Vol. 33, p.1359-1369, 2010.

Brandenburg, L.O.; Varoga, D.; Nicolaeva, N.; Leib, S.L.; Podschun, R.; Wruck, C.J.; Wilms, H.; Lucius, R.; Pufe, T. Expression and regulation of antimicrobial peptide rcramp after bacterial infection in primary rat meningeal cells. J. Neuroimmunol., 217, 55-64. 2009.

Braun, B.J.; Slowik, A.; Leib, S.L.; Lucius, R.; Varoga, D.; Wruck, C.J.; Jansen, S.; Podschun, R.; Pufe, T.; Brandenburg, L.O. The formyl peptide receptor like-1 and scavenger receptor marco are involved in glial cell activation in bacterial meningitis. J. Neuroinflammation, 8, 11-15. 2011.

Brannon-Peppas, L. \& Blanchette, J. O. Nanoparticle and targeted systems for cancer therapy. Adv. Drug Deliv. Rev. V. 56: p. 1649-1659. 2004.

Brentani, M. M., Coelho, F. R. G., Kowalski, L. P. Bases da Oncologia. 2. ed. São Paulo: Editora Marina e Tecmedd. p. 452, 2003.

Boleti APA, Ventura CA, Justo GZ, Silva RA, Sousa ACT, Ferreira CV, Yano T, Macedo MLR. Pouterin, a novel potential cytotoxic lectin-like protein with apoptosis-inducing activity in tumorigenic mammalian cells. Toxicon v. 51; p. 1321 - 1330. 2008.

Brogden, K. A. Antimicrobial peptides: pore formers or metabolic inhibitors in bacteria? Nat Rev Microbiol, v. 3, n³, p. 238-50, 2005. 
Brogden, N. K.; Brogden, K. A. Will new generations of modified antimicrobial peptides improve their potential as pharmaceuticals? Int J Antimicrob Agents, v. 38, n³, p. 217-25, 2011.

Bucki, R.; Leszczynska, K.; Namiot, A.; Sokolowski, W. Cathelicidin II-37: A multitask antimicrobial peptide. Arch. Immunol. Ther. Exp. V. 58, p. 15-25. 2010.

Bulet, P.; Stocklin, R.; Menin, L. Anti-microbial peptides: invertebrates to vertebrates. Immunol Rev, v. 198, p. 169 - 184, 2004.

Buu-Hoi A, Goldstein FW, Acar JF. R-factors in gram-positive and gram-negative aerobic bacteria selected by antimicrobial therapy. Scandinavian Journal of Infectious Diseases V. 49 (supl): p. 46 - 55, 1986.

Brusquetti, F.; La Villa, E. O. Lista comentada de los anfibios de Paraguay. Cuadernos de Herpetologia., v. 20, n³ p. 3 - 79, 2006.

Casadevall, A. Crisis in infectious diseases: time for a new paradigm? Clin Infect Dis, v. 23, n4, p. 790 - 794, 1996.

Casellas JM, Tome G. Resistencia a los antibióticos: algo facil de lograr pero difícil de perder. Epidemiologia Y Vacunas (Buenos Aires - Laboratorio Elea) 2:16, 1998.

Castro, M.S., Ferreira, T.C.G., Cilli, E.M., Crusca E. Jr., Mendesgiannini, M.J.S., Sebben, A., Ricart, C.A.O., Sousa, M.V., Fontes, W. Hylin a1, the first cytolytic peptide isolated from the arboreal South American frog Hypsiboas albopunctatus (spotted treefrog). Peptides. v.30, p.291 - 296, 2009.

Clarke BT. The natural history of amphibian skin secretions, their normal functioning and potential medical applications. Biol Rev; v. 72 p. 365 - 379. 1997. 
Avaliação dos efeitos citotóxicos e antiproliferativos da secreção cutânea e de peptídeos bioativos do anuro Physalaemus nattereri (Steindachner, 1863)

Chandraraj, S.; Prakash, B.; Navanath, K. Immunomodulatory activities of ethyl acetate extracts of two marine sponges Gelliodes fibrosa and Tedania anhelans and brown algae Sargassum ilicifolium with reference to phagocytosis. Research Journal of Pharmaceutical, Biological and Chemical Sciences, v. 1, p. 302-307, 2010.

Chen, L. B. et al. Probing mitochondria in living cells with rhodamine 123. Cold Spring Harbor Symposia on Quantitative Biology, v. 46, p. $141-155$. 1982.

Chen, Y., Xu, X., Hong, S., Chen, J., Liu, N., Underhill, C.B., Creswell, K., Zhang, L. RGD-Tachyplesin Inhibits Tumor Growth. Cancer Research v. 61, p. 2434 2438. 2001.

Chipuk, J. E. E Green, D. R. Dissecting p53-dependent apoptosis. Cell Death \& Differentiation, v. 13, p. 994 - 1002, 2006.

Cholewinski G, Dzierzbicka K, Kołodziejczyk AM. Natural and synthetic acridines/acridones as antitumor agents: their biological activities and methods of synthesis. Pharmacol Rep; v. 63: p. 305 - 336. 2011.

Conlon JM Reflections on a systematic nomenclature for antimicrobial peptides from the skins of frogs of the family Ranidae. Peptides 29:1815-1819. 2008.

Conlon, J. M. Sonnevend A'; Patel M.; Davidson C.; Nielsen P. F.; Pa'l T.; RollinsSmith L. A.; Isolation of peptides of the brevinin-1 family with potent candidacidal activity from the skin secretions of the frog Rana boylii. J. Peptide Res. V. 62, p. 207 -213, 2003.

Conlon, J.M., Iwamuro, S., King, J.D., Ann, N.Y. Dermal cytolytic peptides and the system of innate immunity in anurans, Acad Sci. v. 1163, p. 75 - 82, 2009. 
Avaliação dos efeitos citotóxicos e antiproliferativos da secreção cutânea e de peptídeos bioativos do anuro Physalaemus nattereri (Steindachner, 1863)

Critically important antibacterial agents for human medicine for risk management strategies of non-human use: report of a WHO (World Health Organization ) working group consultation. 2005.

Cruz-Chamorro, L. M.A. Puertollano; E. Puertollano; G.A. de Cienfuegos; M.A. de Pablo In vitro biological activities of magainin alone or in combination with nisin. Peptides. v. 27, p. 1201-1209, 2006.

Cundliffe E. Self defence in antibiotic-producing organisms. British Medical Bulletin V. 40, p. $61-67,1984$.

Cunha, R.B., Castro, M.S., Fontes, W. Espectrometria de massa de proteínas. Biotecnologia Ciência e Desenvolvimento. v. 36, p. 40 - 46, 2006.

Cunha-Filho GA, Resck IS, Cavalcanti BC, Pessoa CO, Moraes MO, Ferreira JR, et al.,. Cytotoxic profile of natural and some modified bufadienolides from toad Rhinella schneideri parotoid gland secretion. Toxicon, v. 56 p. $339-48$. 2010.

Daly, J.W.; Caceres, J.; Moni, R.W.; Gusovsky, F.; Moos, M.Jr; Seamon, K.B.; Milton, K.; Myers, C.W. Frog secretion and hunting magic in upper Amazon: identification of a peptide that interacts with an adenosine receptor. Proceedings of the National. Academy of Sciences USA, V. 89, p.10960 10963. 1992.

Daly JW, Noimai N, Kongkathip B, Kongkathip N, Wilham JM, Garraffo HM, et al. Biologically active substances from amphibians: preliminary studies on anurans from twenty-one genera of Thailand. Toxicon: v. 44 p. $805-815$. 2004. 
Avaliação dos efeitos citotóxicos e antiproliferativos da secreção cutânea e de peptídeos bioativos do anuro Physalaemus nattereri (Steindachner, 1863)

Darzynkiewicz, Z. Bedner, E. Smolewski, P. Cytometry in cell necrobiology: analysis of apoptosis an accidental cell death (necrosis). Cytometry. v. 27, p. $1-20$, 1997.

Dathe, M. \& Wieprecht, T. Structural features of helical antimicrobial peptides: their potential to modulate activity on model membranes and biological cells. Biochim. Biophys. Acta. v. 1462, p. $71-87,1999$.

D'Costa, V. M. et al. Antibiotic resistance is ancient. Nature, V. 477, n. 7365, p. 457461, 2011.

De Smet, K.; Contreras, R. Human antimicrobial peptides: Defensins, cathelicidins and histatins. Biotechnol. Letters, V. 27, p. 1337 - 1347. 2005.

Demain, Al. How do antibiotic - producing microorganisms avoid suicide? Annals of New York Academy of Sciences V. 235, p. 601 - 612, 1974.

Dennison, S. R. Whittaker M., Harris F., Phoenix D.A. Anticancer a-helical peptides and structure/function relationships underpinning their interactions with tumour cell membranes. Current Protein and Peptide Science. v. 7, p. 487-499, 2006.

Denyer, S. P. et al. Hugo and Russell's Pharmaceutical Microbiology. 8th edition. John Wiley \& Sons, 2011.

Dourado, F. S.; Leite, J. R. S. A.; Silva, L. P.; Melo, J. A.T.; Bloch, Jr. C. Schwartz, E. F.;Antimicrobial peptide from the skin secretion of the frog Leptodactylus syphax. Toxicon, V. 50, p. 572 - 580. 2007.

Duellman, W.E. and L. Trueb. Biology of Amphibians. Baltimore: The Johns Hopkins University Press. 670 p. 1994. 
Avaliação dos efeitos citotóxicos e antiproliferativos da secreção cutânea e de peptídeos bioativos do anuro Physalaemus nattereri (Steindachner, 1863)

E Carvalho, A. C. Purificação e Caracterização de Peptídeos Antimicrobianos Isolados Das Secreções Cutâneas de Anuros dos Gêneros Proceratophrys, Physalaemus e Hypsiboas. Dissertação de Mestrado em Biologia Animal da UnB. Brasília. 2011.

Enbäch, J. \& Laakkonen, P. Tumour-homing peptides: tools for targeting, imaging and destruction. Biochemical Society Transactions. v. 35, p. 780-783, 2007.

Erspamer, V.; Falconieri Erspamer, G.; Cei, J.M. Active peptides in the skins of two hundred and thirty American amphibian species. Comparative Biochemistry and Physiology, V. 85, p. $125-137.1986$.

Erspamer, V.; Melchiorri, P.; Falconieri-Erspamer, G.; Negri, L.; Corsi, R.; Severini, C.; Barra, D.; Simmaco, M.; Kreil, G. Deltorphins: a family of naturally occurring peptides with high affinity and selectivity for $\mu$ opioid binding sites. Proceedings of the National Academy of Sciences USA; V. 86, p. 5188 5192. 1989.

Ellerby, H.M., Arap, W., Ellerby, L.M., Kain, R., Andrusiak, R., Rio, G.D., Krajewski, S., Lombardo, C.R., Rao, R., Ruoslahti, E., Bredesen, D.E., Pasqualini, R. Anti-cancer activity of targeted pro-apoptotic peptides. Nat. Med. V. 5, p. 1032 - 1038. 1999.

Favreau, P., Menin, L., Michalet, S., Perret, F., Cheneval, O., Stocklin, M., Bulet, P., Stocklin, R. Mass spectrometry strategies for venom mapping and peptide sequencing from crude venoms: Case applications with single arthropod specimen. Toxicon. v. 47, p. 676-687, 2006.

Feinman SE. Antibiotics in animal feed - Drug resistance revisited. ASM News V. 64, p. 24 - 30, 1998. 
Ferreira, P.M.P., Lima, D.J.B., Debiasi, B.W., Soares, B.M., Machado, K.d.C., Noronha, J.d.C., Rodrigues, D.d.J., Sinhorin, A.P., Pessoa, C., Vieira Júnior, G.M. Antiproliferative activity of Rhinella marina and Rhaebo guttatus venom extracts from Southern Amazon. Toxicon v. 72, p. 43-51. 2013.

Fesik, S. W. Promoting apoptosis as a strategy for cancer drug discovery. Nature Reviews: Cancer. v. 5, p. 876-885, 2005.

Fischbach, M. A.; Walsh, C. T. Antibiotics for emerging pathogens. Science, v. 325, n5944, p. 1089-1093, 2009.

Fleming A. On the antibacterial action of cultures of a Penicillium, with special reference to their use in the isolation o B. influenzae. British Journal of Experimental Pathology V. 10, p. 226 - 236, 1929 (reimpressão Review of Infectious Diseases V. 21, p. 29 - 139, 1980.

Franco, O. L. Peptide promiscuity: an evolutionary concept for plant defense. FEBS Letters, v. 585, no. 7, p. 995 - 1000, 2011.

Freitas, M. A.; Silva, T. F. S. Guia ilustrado - A herpetofauna das caatingas e áreas de altitudes do nordeste brasileiro. Editora USEB, 388p. 2007.

French, G.L. Clinical impact and relevance of antibiotic resistance. Advanced Drug Delivery Rev. Amsterdam. v. 57, p. 1514 - 1527, 2005.

Friedrich C, Scott M G, Karunaratne N, Yan H, Hancock R E. Salt-resistant alphahelical cationic antimicrobial peptides. Antimicrob Agents Chemother, v. 43, n०7, p. 1542-8, 1999.

Frost, D. R. (2015). Amphibian Species of the World: an Online Reference. Acessível em: http://research.amnh.org/herpetology/amphibia/ American Museum of Natural History, New York, USA. Acessado em 03/02/2015. 
Avaliação dos efeitos citotóxicos e antiproliferativos da secreção cutânea e de peptídeos bioativos do anuro Physalaemus nattereri (Steindachner, 1863)

Frohm, M.; Agerberth, B.; Ahangari, G.; Stahle-Backdahl, M.; Liden, S.; Wigzell, H.; Gudmundsson, G.H. The expression of the gene coding for the antibacterial peptide II-37 is induced in human keratinocytes during inflammatory disorders. J. Biol. Chem., V. 272, p. 15258 - 15263. 1997.

Froy, O. Regulation of mammalian defensin expression by toll-like receptordependent and independent signalling pathways. Cell Microbiol., V.7, p. 1387 $-1397.2005$.

Ganz, T. Defensins: Antimicrobial peptides of innate immunity. Nat. Rev. Immunol., 710-720. 2003.

Ghobrial, I. M., Witzig, T.E., Adjei, A.A. Targeting apoptosis pathways in cancer therapy. CA: a Cancer Journal for Clinicians. v. 55, p. 178 - 194, 2005.

Giangaspero, A., Sandri, L., Tossi, A. Amphipathic $\alpha$-helical peptides. A systematic study of the effects of structural and physical properties on biological activity. Eur. J. Biochem. v. 268, p. $5589-5600,2001$.

Giri, B., Gomes, A., Debnath, A., Saha, A., Biswas, A.K., Dasgupta, S.C., Gomes, A. Antiproliferative, cytotoxic and apoptogenic activity of Indian toad (Bufo melanostictus, Schneider) skin extract on U937 and K562 cells. Toxicon 48, 388-400. 2006.

Gomes A, Giri B, Koleb L, Saha A, Debnath A, Gomes A. A crystalline compound (BM-ANF1) from the Indian toad (Bufo melanostictus, Schneider) skin extract, induced anti-proliferation and apoptosis in leukemic and hepatoma cell line involving cell cycle proteins. Toxicon 50: 835-849. 2007.

Globocam. Cancer Incidence, Mortality and Prevalence Worldwide in 2008. Acessado em 03/02/2015. Disponível em: http://globocan.iarc.fr/. 
Avaliação dos efeitos citotóxicos e antiproliferativos da secreção cutânea e de peptídeos bioativos do anuro Physalaemus nattereri (Steindachner, 1863)

Gorman, P. Making magic; Omni Magazine, July. 1993. Extraído de: http://diseyes.lycaeum.org/fresh/nunu.htm

Gudmundsson, G.H.; Agerberth, B.; Odeberg, J.; Bergman, T.; Olsson, B.; Salcedo, $R$. The human gene fall39 and processing of the cathelin precursor to the antibacterial peptide II-37 in granulocytes. Eur. J. Biochem., V. 238, p. 325332. 1996.

Guo, Z.S., Thorne, S.H., Bartlett, D.L. Oncolytic virotherapy: Molecular targets in tumor-selective replication and carrier cell-mediated delivery of oncolytic viruses. Biochimica Biophysica Acta. v. 1785, p. 217 - 231, 2008.

Gwynn, M. N; Portnoy, A., Rittenhouse, S. F.; Payne. D. J.; Challenges of antibacterial discovery revisited. Ann N Y Acad Sci, v.1213, p. 5 - 19, 2010.

Hanahan, D. E Weinberg, R. A. Hallmarks of cancer: the next generation. Cell, v. 144, p. $646-74,2011$.

Hancock, R. E.; Brown, K. L.; Mookherjee, N. Host defence peptides from invertebrates--emerging antimicrobial strategies. Immunobiology, v. 211, $\mathrm{n}^{\circ}$ 4, p. 315-22, 2006.

Hancock, R.E.W. \& Chapple, D.S. Peptide Antibiotics. Antimicrob. Agents and Chemother. Washington. v. 43, p. 1317 - 1323, 1999.

Hashimoto S, Jing Y, Kawazoe N, Masuda Y, Nakajo S, Yoshida T, et al. Bufalin reduces the level of topoisomerase II in human leukemia cells and affects the cytotoxicity of anticancer drugs. Leuk Res; v. 21: p. 875 - 883. 1997.

Higa GM. The microtubule as a breast cancer target. Breast Câncer; v.18; p. 103 119. 2011. 
Avaliação dos efeitos citotóxicos e antiproliferativos da secreção cutânea e de peptídeos bioativos do anuro Physalaemus nattereri (Steindachner, 1863)

Honorato, C. T. M. análise peptidômica da secreção cutânea do anuro Physalaemus nattereri com ênfase na prospecção de peptídeos antimicrobianos. Dissertação de mestrado em Biologia Animal da UnB. Brasília, 2009.

Hoskin, D.W. \& Ramamoorthy, A. Studies on anticancer activities of antimicrobial peptides. Biochim. Biophys. Acta. v. 1778, p. 357-375, 2008.

Huang, H. W. Action of antimicrobial peptides: two-state model. Biochemistry, v. 39, n²9, p. 8347 - 8352, 2000.

Huang, Y.; Huang, J.; Chen, Y. Alpha-helical cationic antimicrobial peptides: relationships of structure and function. Protein Cell, v. 1, n. 2, p. 143-52, 2010.

Huttner, K.M.; Bevins, C.L. Antimicrobial peptides as mediators of epithelial host defense. Pediatr. Res. V. 45, 785 - 794. 1999.

Instituto Nacional do Câncer (2015). Informações sobre o câncer. Disponível em http://www2.inca.gov.br/wps/wcm/connect/cancer/site/oquee. Acessado em 10/01/2015.

Igney, F.H. \& Krammer, P.H. Death and anti-death: tumour resistance to apoptosis. Nature Reviews: Cancer. v. 2, p. 277-288, 2002.

Irigaray, P., Newby, J. A., Clapp, R., Hardell, L., Howard, V., Montagnier, L., Epstein, S. E Belpomme, D. Lifestyle-related factors and environmental agents causing cancer: an overview. Biomedicine \& Pharmacotherapy, v. 61, p. 640 - 658, 2007.

Jin, Z. \& El-Deiry, W.S. Overview of cell death signaling pathways. Cancer Biology \& Therapy. v. 4, p. $139-163,2005$. 
Jolivet-Gougeon, A. et al. Bacterial hypermutation: clinical implications. J Med Microbiol, v. 60, n. Pt 5, p. 563 - 573, 2011.

Joseph, M.H. \& Marsden, C.A. HPLC of small molecules a practical approach. Oxford. IRL Press Limited. p. 100, 1986.

Kamano $\mathrm{Y}$, Kotake A, Hashima H, Inoue M, Morita H, Takeya $\mathrm{K}$, et al., Structurecytotoxic activity relationship for the toad poison bufadienolides. Bioorg Med Chem; v. 6: p. 1103 -1115. 1998.

Kasahara, M.; Suzuki, T.; Pasquier, L.D. On the origins of the adaptive immune system: Novel insights from invertebrates and cold-blooded vertebrates. Trends Immunol. V. 25, p. $105-111.2004$.

Kelloff, G.J. Crowell JA, Steele VE, Lubet RA, Malone WA, Boone CW, Kopelovich L, Hawk ET, Lieberman R, Lawrence JA, Ali I, Viner JL, Sigman CC. Progress in cancer chemoprevention: development of diet-derived chemopreventive agents. J Nutr. v. 130, p. 467S - 710S, 2000.

Kollef, M. H.; Fraser, V. J. Antibiotic resistance in the intensive care unit. Ann Intern Med, v. 134, no4, p. 298 - 314, 2001.

Krenn L, Kopp B. Bufadienolides from animal and plant sources. Phytochemistry; v. 48: p. 1 - 29. 1998.

Kim, S. Kim SS, Bang YJ, Kim SJ, Lee BJ. In vitro activities of native and designed peptide antibiotics against drug sensitive and resistant tumor cell lines. Peptides. v. 24, p. 945 - 953, 2003.

Krugliak, M., Feder, R., Zolotarev, V.Y., Gaidukov, L., Dagan, A., Ginsburg, H., Mor, A. Antimalarial activities of dermaseptin S4 derivatives. Antimicrob. Agents Chemother. v. 44, p. 2442 - 2451, 2000. 
Lai, Y.; Gallo, R. L. AMPed up immunity: how antimicrobial peptides have multiple roles in immune defense. Trends Immunol, v. 30, n. 3, p. 131 - 410, 2009.

La Villa; O., E.; CEl., J. M. Amphibians of Argentina. A Second Update, 1987-2000. Museo Regionale di Scienze Naturali. Torino, v. 28, p. 1 - 177, 2001.

Lehrer, R.I.; Lu, W. Alpha-defensins in human innate immunity. Immunol. Rev. V. 245, p. $84-112.2012$.

Lenzi-Mattos S, R. R. Antoniazzi, M. M. Haddad, C. F. B. Tambourgi, D. V. Rodrigues, M. T. Jared, C. The inguinal macroglands of the frog Physalaemus nattereri (Leptodactylidae): structure, toxic secretion and relationship with deimatic behaviour. The Zoological Society of London V. 266 p. 385 - 394. 2005.

Levy SB. Microbial resistance to antibiotics. Lancet V. 2, p. 83 - 88, 1982.

Levy, C. E. Manual de Microbiologia Clínica para o Controle de Infecção em Serviços de Saúde. 2004.

Li J, Xu X, Xu C, Zhou W, Zhang K, Yu H, Zhang Y, Zheng Y, Rees HH, Lai R, Yang D, Wu J Anti-infection peptidomics of amphibian skin. Mol Cell Proteomics V. 6, p. $882-894.2007$.

Libério, M.S., Joanitti, G.A., Azevedo, R.B., Cilli, E.M., Zanotta, L.C., Nascimento, A.C., Sousa, M.V., Pires Júnior, O.R., Fontes, W., Castro, M.S. Antiproliferative and cytotoxic activity of pentadactylin isolated from Leptodactylus labyrinthicus on melanoma cells. Amino Acids v. 40, p. 51 - 59. 2011.

Libério, M.S., Joanitti, G.A., Fontes, W., Castro, M.S. Anticancer peptides and proteins: a panoramic view. Protein and Peptide Letters v. 20, p. 380 - 391. 2013. 
Libério, M. S. Caracterização química e biológica da secreção cutânea do anuro Leptodactylus labyrinthicus: peptídeos antimicrobianos e anticarcinogênicos, fosfolipases e peptidases. Dissertação de mestrado em Biologia Animal da UnB. Brasília, 2008.

Liu Y, Xiao Y, Xue X, Zhang X, Liang X. Systematic screening and characterization of novel bufadienolides from toad skin using ultra-performance liquid chromatography/electrospray ionization quadrupole time-of-flight mass spectrometry. Rapid Commun Mass Spectrom; v. 24: p. 667 - 678. 2010.

Linton AH. Antibiotic-resistant bacteria in animal husbandry. British Medical Bulletin V. 40: p. 91 - 95, 1984.

Lofgren, S. E. Miletti LC, Steindel M, Bachere E, Barracco MA. Trypanocidal and leishmanicidal activities of different antimicrobial peptides (AMPs) isolated from aquatic animals. Exp Parasitol, v. 118, n², p. 197 - 202, 2008.

Lorin, C., Saidi, H., Belaid, A., Zairi, A., Baleux, F., Hocini, H., Belec, L., Hani, K., Tangy, F. The antimicrobial peptide Dermaseptin S4 inhibits HIV-1 infectivity in vitro. Virology. v. 334, p. 264 - 275, 2005.

Maciel NM, Schwartz CA, Rodrigues Pires Júnior O, Sebben A, Castro MS, Sousa MV, Fontes W, Ferroni Schwartz EN. Composition of indolealkylamines of Bufo rubescens cutaneous secretions compared to six other Brazilian bufonids with phylogenetic implications. Comp Biochem Physiol B; v. 134; p. $641-$ 649. 2003.

Mader, J.S., Hoskin, D.W. Cationic antimicrobial peptides as novel cytotoxic agents for cancer treatment. Expert Opinion on Investigational Drugs v. 15, p. 933 - 946. 2006. 
Mangoni, M. L, Niv Papo, José M. Saugar, Donatella B, Yechiel Shai, Maurizio Simmaco, Luis Rivas. Effect of Natural L- to D-Amino Acid Conversion on the Organization, Membrane Binding, and Biological Function of the Antimicrobial Peptides Bombinins H Biochemistry: v. 45, p. 4266 - 4276. 2006.

Masui, K., Gini, B., Wykosky, J., Zanca, C., Mischel, P. S., Furnari, F. B., \& Cavenee, W. K. A tale of two approaches: complementary mechanisms of cytotoxic and targeted therapy resistance may inform next-generation cancer treatments. Carcinogenesis, 34 (4), 725-38, 2013.

Majno, G. \& Joris, I. Apoptosis, oncosis, and necrosis. An overview of cell death. The American Journal of Pathology. v. 146, p. 3 - 15, 1995.

Matsuzaki, K. Why and how are peptide-lipid interactions utilizes for selfdefense? Magainins and tachyplesins as archetypes. Biochim. Biophys. Acta. v. 1462, p. 1-10, 1999.

Mattos, R.L.; Antoniazzi, M.M.; Haddad, C; Jared, C. Structure of venom glands in the frog Physalaemus nattereri (Anura, Leptodactylidae). Acta Microscopica, V. 12B, 563 - 564. 2003.

Melo-E-Silva, D. D. et al. Morphometric and genetic differentiation among populations of Eupemphix nattereri (Amphibia, Anura, Leiuperidae) from central Brazil. Iheringia. Série Zoologia, v. 98, p. 493 - 500, 2008.

McGwire, B.S.; Olson, C.L.; Tack, B.F.; Engman, D.M. Killing of african trypanosomes by antimicrobial peptides. J. Infect. Dis. V. 188, p. 146-152. 2003.

Mignogna, G.; Severini, C.; Sirmmaco, M.; Negri, L.; Erspamer, G.F.; Kreil, G.; Barra, $D$. Identification and characterization of two dermophins from skin extracts of the Amazonian frog Phyllomedusa bicolor. FEBS, V. 302, p. 151 - 154. 1992. 
Avaliação dos efeitos citotóxicos e antiproliferativos da secreção cutânea e de peptídeos bioativos do anuro Physalaemus nattereri (Steindachner, 1863)

Mor, A. \& Nicolas, P. The NH2-terminal alpha-helical domain 1-18 of dermaseptin is responsible for antimicrobial activity. J. Biol. Chem. v. 269, p. $1934-1939$, 1994.

Mor, A., Nguyen, V.H., Delfour, A., Migliore-Samur, D., Nicolas, P. Isolation, amino acid sequence, and synthesis of dermaseptin, a novel antimicrobial peptide of amphibian skin. Biochem. v. 30, p. 8824 - 8830, 1991.

Morton, C.O., Dos Santos, S.C., Coote, P. An amphibian-derived, cationic, alphahelical antimicrobial peptide kills yeast by caspase-independent but AlFdependent programmed cell death. Mol. Microbiol. v. 65, p. 494 - 507, 2007.

Mosmann, T. Rapid colorimetric assay for cellular growth and survival: application to proliferation and cytotoxicity assays. Journal of Immunological Methods, V. 65, p. 55 - 63. 1983.

National Cancer Institute. What You Need To Know About: Melanoma and Other Skin Cancers. U.S. Department of Health And Human Services, National Institutes Of Health. p. 1 - 59. 2010.

Nascimento, A. C. C. et al. Protein and Peptide Letters. v. 10, p. 227, 2003.

Negri, L.; Erspamer, G.F.; Severini, C.; Potenza, R.L.; Melchiorri, P.; Erspamer, V. Dermophin-related peptides from the skin of Phyllomedusa bicolor and their amidated analogs activate two $\mu$ opioid receptors subtypes that modulate antinociception and catalepsy in the rat. Proceedings of the National Academy of Sciences USA, V. 89, p. 7203 - 7207. 1992.

Newman DJ, Cragg GM, Snader KM. The influence of natural products upon drug discovery. Nat Prod Rep. v. 17: p. 215-234. 2000. 
Newman, D.J., Cragg, G.M., Snader, K.M. Natural products as sources of new drugs over the period 1981-2002 Nat. Prod. Rep. v. 66, p. 1022, 2003.

Nguyen, L. T.; Haney, E. F.; Vogel, H. J. The expanding scope of antimicrobial peptide structures and their modes of action. Trends Biotechnol, v. 29, $n^{\circ} 9$, p. 464 - 472, 2011.

Nizet, V.; Gallo, R.L. Cathelicidins and innate defense against invasive bacterial infection. Scand. J. Infect. Dis., 35, 670-676. 2003.

Nogawa T, Kamano Y, Yamashita A, Pettit GR. Isolation and structure of five new cancer cell growth inhibitory bufadienolides from the Chinese traditional drug Ch'an Su. Journal Nat Prod; v. 64; p. 1148 - 1152. 2001.

Oguiura, Nancy et al. In vitro antibacterial and hemolytic activities of crotamine, a small basic myotoxin from rattlesnake Crotalus durissus. J Antibiot v. $64, \mathrm{n}^{\circ}$ 4, p. $327-331,2011$.

Okada, H. \& Mak, T. W. Pathways of apoptotic and non-apoptotic death in tumour cells. Nature Reviews: Cancer. v. 4, p. 592 - 603, 2004.

Okeke IN, Laxminarayan R, Bhutta ZA, Duse AG, Jenkins P, O'Brien TF, PablosMendez A, Klugman KP. Antimicrobial resistance in developing countries. Part I: recent trends and current status. The Lancet Infectious diseases. Nova York. v. 5, p. 481 - 493, 2005. 
Okubo BM, Silva ON, Migliolo L, Gomes DG, Porto WF,. Evaluation of an antimicrobial L-amino acid oxidase and peptide derivatives from Bothropoides mattogrosensis pitviper venom. PLoS One, v. 7, n³, p. 336 - 339, 2012.

Ogasawara M, Matsubara T, Suzuki H. Screening of natural compounds for inhibitory activity on colon cancer cell migration. Biol Pharm Bull; v. 24; p. $720-723$. 2001.

Oren, Z.; Hong, J.; Shai, Y. A comparative study on the structure and function of a cytolytic alpha-helical peptide and its antimicrobial beta-sheet diastereomer. Eur J. Biochem, v. 259, n¹-2, p. 360 - 369, 1999.

Otero-Gonzalez, A. J. Magalhaes BS, Garcia-Villarino M, Lopez-Abarrategui C, Sousa DA, Dias SC, Franco OL. Antimicrobial peptides from marine invertebrates as a new frontier for microbial infection control. FASEB J, v. 24, n5, p. 1320 - 1334, 2010.

Ott, M., Robertson, J.D., Gogvadze, V., Zhivotovsky, B., Orrenius, S., Cytochrome c release from mitochondria proceeds by a two-step process. Proceedings of the National Academy of Sciences of the United States of America v. 99, p. 1259 - 1263. 2002.

Padovan, L.; Segat, L.; Pontillo, A.; Antcheva, N.; Tossi, A.; Crovella, S. Histatins in non-human primates: Gene variations and functional effects. Protein Pept. Lett., V. 17, p. 909 - 918. 2010.

Palma, M., Mendes, M., Marques, M., Souza, B., Santos, L., Santos, K. Fundamentos em analise proteômica, parte I. Laboratório de biologia estrutural. p. 110, 2007.

Papo N. \& Shai, Y. New lytic peptides based on the DL-amphipathic helix motif preferentially kill tumor cells compared to normal cells. Biochemistry. v. 42, p. 9346 - 9354, 2003. 
Avaliação dos efeitos citotóxicos e antiproliferativos da secreção cutânea e de peptídeos bioativos do anuro Physalaemus nattereri (Steindachner, 1863)

Papo, N. \& Shai, Y. Host defense peptides as new weapons in cancer treatment. Cell. Mol. Life Sci. v. 62, p. $784-790,2005$.

Pazgier, M.; Li, X.; Lu, W.; Lubkowski, J. Human defensins: Synthesis and structural properties. Curr. Pharm. Des. V. 13, p. 3096 - 3118. 2007.

Peres, C. M. Curi, R. Como Cultivar Células: Rio de Janeiro: Guanabara Koogan S.A., p. 283, 2005.

Peters, B. M.; Shirtliff, M. E.; Jabra-Rizk, M. A. Antimicrobial peptides: primeval molecules or future drugs? PLoS Pathog, v. 6, n¹0, p. 1001 - 1067, 2010.

Pogue, J. M. et al. Role of unit-specific combination antibiograms for improving the selection of appropriate empiric therapy for gram-negative pneumonia. Infect Control Hosp Epidemiol, v. 32, n³, p. 289 - 292, 2011.

Pukala, T.L., Bowie, J.H., Maselli, V.M., Musgrave, I.F., Tyler, M.J. Hostdefence peptides from the glandular secretions of amphibians: structure and activity. Nat. Prod. Rep. V. 23, p. 368 - 393, 2006.

Qi, F., Li, A., Inagaki, Y., Kokudo, N., Tamura, S., Nakata, M., Tang, W. Antitumor activity of extracts and compounds from the skin of the toad Bufo bufo gargarizans Cantor. International Immunopharmacology v. 11, p. 342 - 349. 2011.

Qi, F., Li, A., Zhao, L., Xu, H., Inagaki, Y., Wang, D., Cui, X., Gao, B., Kokudo, N., Nakata, M., Tang, W. Cinobufacini, an aqueous extract from Bufo bufo gargarizans Cantor, induces apoptosis through a mitochondria-mediated pathway in human hepatocellular carcinoma cells. Journal of Ethnopharmacology v. 128, p. 654 - 661. 2010. 
Avaliação dos efeitos citotóxicos e antiproliferativos da secreção cutânea e de peptídeos bioativos do anuro Physalaemus nattereri (Steindachner, 1863)

Reddy, K. V. R.; Shahani, S. H. \& Meherji, P. K. Spermicidal activity of magainins: in vitro and in vivo studies. Contraception. V. 53; p. 205 -210. 1996.

Reddy, K. V. R.; Yedery, R. D. \& Aranha, C. Antimicrobial peptides: premises and promises. International Journal of Antimicrobial Agents. V. 24; p. 536 547. 2004

Rinaldi, A.C. Antimicrobial peptides from amphibian skin: an expanding scenario. Curr. Opin. Chem. Biol, V. 6 (6), p. 799 - 804. 2002.

Riccardi C, Nicoletti; Analysis of apoptosis by propidium iodide staining and flow cytometry. Nat Protoc V. 1, p. 1458 - 1461. 2006.

Riva, D. L. et al. Ten years of research on Bolivian amphibians: updated checklist, distribution, taxonomic problems, literature and iconography. Revista Española de Herpetología, v. 14, p. 19 - 164, 2000.

Rodrigues, E.G. Dobroff, A. S.; Cavarsan, C.F.; Paschoalin, T.; Nimrichter, L.; Mortara, R.; Santos, E. L.; Fazio, M.A.; Miranda, A.; Daffre, S.; Travassos, L. R. Effective topical treatment of subcutaneous murine B16F10-Nex2 melanoma by the antimicrobial peptide gomesin. Neoplasia. V. 10, p. 61 - 68, 2008.

Rollins-Smith LA, KingJD, Nielsen PF, Sonnevend A \& Conlon JM. An antimicrobial peptide from the skin secretions of the mountain chicken frog Leptodactylus fallaz (Anura: Leptodactylidae). Regulatory Peptides V. 124: p.173 - 178. 2005.

Rossi, F. The challenges of antimicrobial resistance in Brazil. Clin Infect Dis, V. 52, $n^{\circ} 9$, p. $1138-1143,2011$.

Ronot X, Benel L, Adolphe M, Mounolou JC. Mitochondrial analysis in living cells: the use of rhodamine 123 and flow cytometry. Biol Cell v. 57; p. 1 - 7. 1986. 
Avaliação dos efeitos citotóxicos e antiproliferativos da secreção cutânea e de peptídeos bioativos do anuro Physalaemus nattereri (Steindachner, 1863)

Sai KP, Jagannadham MV, Vairamani M, Raju NP, Devi A, Nagaraj S, Sitaram N Tigerinins: novel antimicrobial peptides from the Indian frog Rana tigerina. Journal Biol Chem V. 276, p. 2701 - 2707. 2001.

Sang $\mathrm{Y}$, Blecha $\mathrm{F}$ Antimicrobial peptides and bacteriocins: alternatives to traditional antibiotics. Anim Health Res Rev n`9, p. 227 - 235. 2008.

Saunders JR. Genetics and evolution of antibiotic resistance. British Medical Bulletin V. 40, p. 54 - 60, 1984.

Saraste, A. Pulkki, K. Morphologic and biochemical hallmarks of apoptosis. Cardiovasc Res V. 45, p. $528-370.2000$.

Savill, J. \& Fadok, V. Corpse clearance defines the meaning of cell death. Nature. v. 407, p. $784-788,2000$.

Schmieder, R.; Edwards, R. Insights into antibiotic resistance through metagenomic approaches. Future Microbiol, V. 7, n¹, p. $73-89,2012$.

Schmeda-Hirschmann, G., Quispe, C., Theoduloz, C., de Sousa Jr, P.T., Parizotto, C. Antiproliferative activity and new argininyl bufadienolide esters from the "cururú" toad Rhinella (Bufo) schneideri. Journal of Ethnopharmacology v. 155; p. 1076 - 1085. 2014.

Sciani, J. M., de-Sá-Júnior, P. L., Ferreira, A. K., Pereira, A., Antoniazzi, M. M., Jared, C., \& Pimenta, D. C. Cytotoxic and antiproliferative effects of crude amphibian skin secretions on breast tumor cells. Biomedicine \& Preventive Nutrition, V. 3; p. $10-18.2013$.

Sciani JM, Angeli CB, Jared C, Antoniazzi MM, Pimenta DC. Differences and Similarities among Parotoid Macrogland Secretions in South American Toads: 
Avaliação dos efeitos citotóxicos e antiproliferativos da secreção cutânea e de peptídeos bioativos do anuro Physalaemus nattereri (Steindachner, 1863)

A Preliminary Biochemical Delineation. The Scientific World Journal; 1 - 9. 2013.

Shaw C. Venom-based medicines advancing drug discovery with reptile and amphibian venom peptides. Biochemist; v. 31; p. 34 - 37. 2009.

Shadidi, M. \& Sioud, M. Selective targeting of cancer cells using synthetic peptides. Drug Res. Updates. v. 6, p. $363-371,2003$.

Serra, I., Scorciapino, M.A., Manzo, G., Casu, M., Rinaldi, A.C., Attoub, S., Mechkarska, M., Conlon, J.M. Conformational analysis and cytotoxic activities of the frog skin host-defense peptide, hymenochirin-1Pa. Peptides v. 61; $\mathrm{p}$. 114 - 121.2014.

Spinosa, M.R., Progida, C., Tala, A., Cogli, L., Alifano, P., and Bucci, C.The Neisseria meningitidis capsule is important for intracellular survival in human cells. Infect Immun 75: 3594-3603, 2007.

Silva ON, Porto WF, Migliolo L, Mandal SM, Gomes DG, Exploring the pharmacological potential of promiscuous host-defense peptides: from natural screenings to biotechnological applications. Front Microbiol, v. 2, p. 232, 2011.

Simmaco, M., Mignogna, G., Barra, D. Antimicrobial peptides from amphibian skin: what do they tell us? Biopolymers. v. 47, p. 435-450, 1998.

Souza, Moisés B. Diversidade de Anfíbios nas Unidades de Conservação Ambiental: Reserva Extrativista do Alto Juruá (REAJ) e Parque Nacional da Serra do Divisor (PNSD), Acre - Brasil - UNESP- Rio Claro, SP. p. 56 - 57. (Tese de doutorado). 2003. 
Staubitz, P., A. Peschel, W. F. Nieuwenhuizen, M. Otto, F. Gotz, G. Jung, and R. W. Jack. Structure-function relationships in the tryptophan-rich, antimicrobial peptide indolicidin. J Pept Sci, V. 7, n¹0, p. 552 - 564, 2001.

Stewart, B.W. \& Coates, A.S. Cancer prevention: a global perspective. J Clin Oncol. v. 23, p. $392-403,2005$.

Stotz, H.U.; Thomson, J.G.; Wang, Y. Plant defensins: Defense, development and application. Plant Signal. Behav. V. 4, p. 1010 - 1012, 2009.

Suassuna I, Suassuna IR. Perspectivas do emprego clínico dos antibióticos. Tribuna Médica V. 14, P. 10 - 17. 1971.

Subik K, Lee JF, Baxter L, Strzepek T, Costello D, Crowley P, et al. The expression patterns of ER, PR, HER2, CK5/6, EGFR, Ki-67 and AR by immunohistochemical analysis in breast cancer cell lines. Breast Cancer; v. 4; p. $35-41.2010$.

Subbalakshmi, C.; Sitaram, N. Mechanism of antimicrobial action of indolicidin. FEMS Microbiol Lett, v. 160, n¹, p. 91 - 96, 1998.

Sykes, R. S. The 2009 Garrod lecture: the evolution of antimicrobial resistance: a Darwinian perspective. J Antimicrob Chemother, V. 65, n`9, p. 1842 - 1852, 2010.

Tarasov, V.A.; Khadeeva, N.V.; Mel'nik, V.A.; Ezhova, T.A.; Shestakov, S.V. The atlg12860 gene of arabidopsis thaliana determines cathelicidin-like antimicrobial activity. Dokl. Biol. Sci., V. 427, p. 332 - 334. 2009. 
Avaliação dos efeitos citotóxicos e antiproliferativos da secreção cutânea e de peptídeos bioativos do anuro Physalaemus nattereri (Steindachner, 1863)

Tincu, J. A.; Taylor, S. W. Antimicrobial peptides from marine invertebrates. Antimicrob Agents Chemother, v. 48, nº10, p. 3645 - 3654, 2004.

Toledo, R. C. \& Jared, C. Cutaneous granular glands and amphibian venoms. Camp. Biochem. Physiol. v. 111 (1), p. 1 - 29, 1995.

Tongaonkar, P.; Tran, P.; Roberts, K.; Schaal, J.; Osapay, G.; Tran, D.; Ouellette, A.J.; Selsted, M.E. Rhesus macaque theta-defensin isoforms: Expression, antimicrobial activities, and demonstration of a prominent role in neutrophil granule microbicidal activities. J. Leukoc. Biol. V. 89, p. 283 - 290. 2011.

Tu WC, Wu CC, Hsieh HL, Chen CY, Hsu SL. Honeybee venom induces calciumdependent but caspase-independent apoptotic cell death in human melanoma A2058 cells. Toxicon v. 52; p. 318 - 329. 2008.

Thompson JF, Scolyer RA, Kefford RF. Cutaneous melanoma. Lancet, v. 365; p. 687 - 701. 2005.

Thun, M. J., Delancey, J. O., Center, M. M., Jemal, A. E Ward, E. M. The global burden of cancer: priorities for prevention. Carcinogenesis, v. 31, p. $100-10$, 2010.

Van Zoggel, H., Hamma-Kourbali, Y., Galanth, C., Ladram, A., Nicolas, P., Courty, J., Amiche, M., Delbé, J. Antitumor and angiostatic peptides from frog skin secretions. Amino Acids. p. 385 - 395, 2012.

Van Zoggel H, Carpentier G, Dos Santos C, Hamma-Kourbali Y, Courty J, et al. (2012) Antitumor and Angiostatic Activities of the Antimicrobial Peptide Dermaseptin B2. PLoS ONE v. 7(9): e44351. 
Avaliação dos efeitos citotóxicos e antiproliferativos da secreção cutânea e de peptídeos bioativos do anuro Physalaemus nattereri (Steindachner, 1863)

Varoga, D.; Pufe, T.; Mentlein, R.; Kohrs, S.; Grohmann, S.; Tillmann, B.; Hassenpflug, J.; Paulsen, F. Expression and regulation of antimicrobial peptides in articular joints. Ann. Anat., V. 187, p. $499-508.2005$.

Wang X, Song $\mathrm{Y}$, Li J, Liu H, Xu X, Lai R, Zhang $\mathrm{K} \mathrm{A}$ new family of antimicrobial peptides from skin secretions of Rana pleurade. Peptides V. 28, p. 2069 2074. 2007.

Wang, G.; Li, X.; Wang, Z. APD2: the updated antimicrobial peptide database and its application in peptide design. Nucleic Acids Res, V. 37, p. 933 - 937. 2009.

Wang, Y. D. Pan CY, Rajanbabu V, Chan YL, Wu CJ, Chen JY. Inactivation of nervous necrosis virus infecting grouper (Epinephelus coioides) by epinecidin1 and hepcidin 1-5 antimicrobial peptides, and downregulation of $M \times 2$ and Mx3 gene expressions. Fish Shellfish Immunol, v. 28, n 1, p. $113-120$, 2010.

Wang, C., Li, H.B., Li, S., Tian, L.L., Shang, D.J. Antitumor effects and cell selectivity of temporin-1CEa, an antimicrobial peptide from the skin secretions of the Chinese brown frog (Rana chensinensis). Biochimie, v. 94; p. 434 - 441. 2012.

Wang, C., Tian, L.L., Li, S., Li, H.B., Zhou, Y., Wang, H., Yang, Q.Z., Ma, L.J., Shang, D.J. Rapid cytotoxicity of antimicrobial peptide temporin-1CEa in breast cancer cells through membrane destruction and intracellular calcium mechanism. PloS One 8, e60462. 2013.

Weinberg, R. A. The Biology of Cancer. New York: Garland Science, Taylor \& Francis Group, 850 p. 2006. 
Avaliação dos efeitos citotóxicos e antiproliferativos da secreção cutânea e de peptídeos bioativos do anuro Physalaemus nattereri (Steindachner, 1863)

Winder, D. et al. Expression of antimicrobial peptide has an antitumor effect in human cells. Biochem. Biophys. Res. Commun. V. 242: p.608-612. 1998.

WHO. (World Health Organization International Agency for Research on Cancer). World Câncer Report. Acessado em 03/02/2015. Disponível em: http://www.who.int/cancer/en/

WHO. Critically important antibacterial agents for human medicine for risk management strategies of non-human use: report of a WHO working group consultation. 2005.

Wiesner, J.; Vilcinskas, A. Antimicrobial peptides: The ancient arm of the human immune system. Virulence. V.1, p. $440-464.2010$.

Witte W. Medical consequences of antibiotic use in agriculture. Science 279:996997, 1998.

Wood, K.; Cluzel, P. Trade-offs between drug toxicity and benefit in the multiantibiotic resistance system underlie optimal growth of E. coli. BMC Syst Biol, v. 6, nㅇ, p. $48,2012$.

World Health Organization Scientific Group. Antimicrobial resistance. Bulletin of World Health Organization V. 61, p. 383 - 394, 1983.

Wu, M.; Hancock, R. E. Improved derivatives of bactenecin, a cyclic dodecameric antimicrobial cationic peptide. Antimicrob Agents Chemother, V. 43, n5, p. 1274 - 1276, 1999.

Ye M, Guo D. Analysis of bufadienolides in the Chinese drug Ch'an Su by highperformance liquid chromatography with atmospheric pressure chemical 
Avaliação dos efeitos citotóxicos e antiproliferativos da secreção cutânea e de peptídeos bioativos do anuro Physalaemus nattereri (Steindachner, 1863)

ionization tandem mass spectrometry. Rapid Commun Mass Spectrom; v.19; p. 1881 - 1892. 2005.

Yeh JY, Huang WJ, Kan SF, Wang PS. Effects of bufalin and cinobufagin on the proliferation of androgen dependent and independent prostate cancer cells. Prostate; v. 54; p. $112-24.2003$.

Yeaman, M.R. \& Yount, N.Y. Mechanisms of Antimicrobial Peptide Action and Resistence. Pharmacol. Rev. v. 55, p. 27 - 55, 2003.

Youle, R.J. \& Strasser, A. The BCL-2 protein family: opposing activities that mediate cell death. Nature Reviews: Molecular Cell Biology. v. 9, p. 47 - 59, 2008.

Zaiou, M. Multifunctional antimicrobial peptides: Therapeutic targets in several human diseases. J. Mol. Med., V. 85, p. 317 - 329. 2007.

Zasloff, M. Antibiotic peptides as mediators of innate immunity. Curr Opin Immunol, v. $4, n^{\circ} 1$, p. $3-7,1992$.

Zasloff, M. Antimicrobial peptides of multicellular organisms. Nat. v. 415, p. 389- 395, 2002.

Zasloff, M. Magainins, a class of antimicrobial peptides from Xenopus skin: isolation, characterization of two active forms, and partial cDNA sequence of a precursor. Proc. Natl. Acad. Sci. v. 84, p. 5449 - 5453, 1987.

Zelezetsky, I. Controlled alteration of the shape and conformational stability of $\alpha$ helical cell-lytic peptides: effect on mode of action and cell specificity. Biochem. J. V. 390, p. 177 - 188, 2005.

Zhang LS, Nakaya K, Yoshida T, Kuroiwa Y. Induction by bufalin of differentiation of human leukemia cells HL60, U937, and ML1 toward macrophage/monocytelike cells and its potent synergistic effect on the differentiation of human 
Avaliação dos efeitos citotóxicos e antiproliferativos da secreção cutânea e de peptídeos bioativos do anuro Physalaemus nattereri (Steindachner, 1863)

leukemia cells in combination with other inducers. Cancer Res; v. 52; p. 4634 - 4641.1992.

Zhang Y, Rishi AK, Dawson MI, Tschang R, Farhana L, Boyanapalli M, Reichert U, ShrBooot B, Buren ECV, Fontana JA. S-phase arrest and apoptosis induced in normal mammary epithelial cells by a novel retinoid. Cancer Res. V. 60; p. 2025 - 2032. 2000.

Zheng, H. Ojha, PC. McClean, Stephen. Graham, C. Black, ND. Hughes, JG. Shaw, C; A computational approach for peptidomic analysis in taxonomic study of amphibian species. IEE Transactions on Nanobioscience. v. 4, p. $241-$ 247, 2005.

Zhu, Z. \& Witte, L. Inhibition of tumor growth and metastasis by targeting tumorassociated angiogenesis with antagonists to the receptors of vascular endothelial growth factor. Investigational New Drugs. v. 17, p. $195-212$, 1999.

Zhu H, Zhang L, Wu S, Teraishi F, Davis JJ, Jacob D, Fang B. Induction of S-phase arrest and p21 overexpression by a small molecule [2,3-(2,3dichlorophenoxy)propyl] amino]ethanol in correlation with activation of ERK. Oncogene. v. 23; p. 4984 - 4992. 2004. 